UNIVERSIDADE DE SÃO PAULO

INSTITUTO DE GEOCIÊNCIAS

\title{
VARIEDADES GEMOLÓGICAS DE QUARTZO NA BAHIA, GEOLOGIA, MINERALOGIA, CAUSAS DE COR, E TÉCNICAS DE TRATAMENTO
}

\section{Monica Correa}

Orientador: Prof. Dr. Rainer Aloys Schultz Güttler.

\author{
DISSERTAÇÃO DE MESTRADO \\ Programa de Pós-Graduação em Mineralogia e Petrologia
}

São Paulo 
MONICA CORREA

\section{Variedades Gemológicas de Quartzo na Bahia, Geologia, Mineralogia, Causas de Cor, e Técnicas de Tratamento}

Dissertação apresentada ao Instituto de Geociências da Universidade de São Paulo para obtenção do título de Mestre em Geologia.

Programa de Pós-Graduação em Mineralogia e Petrologia

Área de Concentração: Mineralogia Experimental e Aplicada.

Orientador: Prof. Dr. Rainer Aloys Schultz Güttler.

São Paulo 
Autorizo a reprodução e divulgação total ou parcial deste trabalho, por qualquer meio convencional ou eletrônico, para fins de estudo e pesquisa, desde que citada a fonte.

Ficha catalográfica preparada pelo Serviço de Biblioteca e Documentação do Instituto de Geociências da Universidade de São Paulo

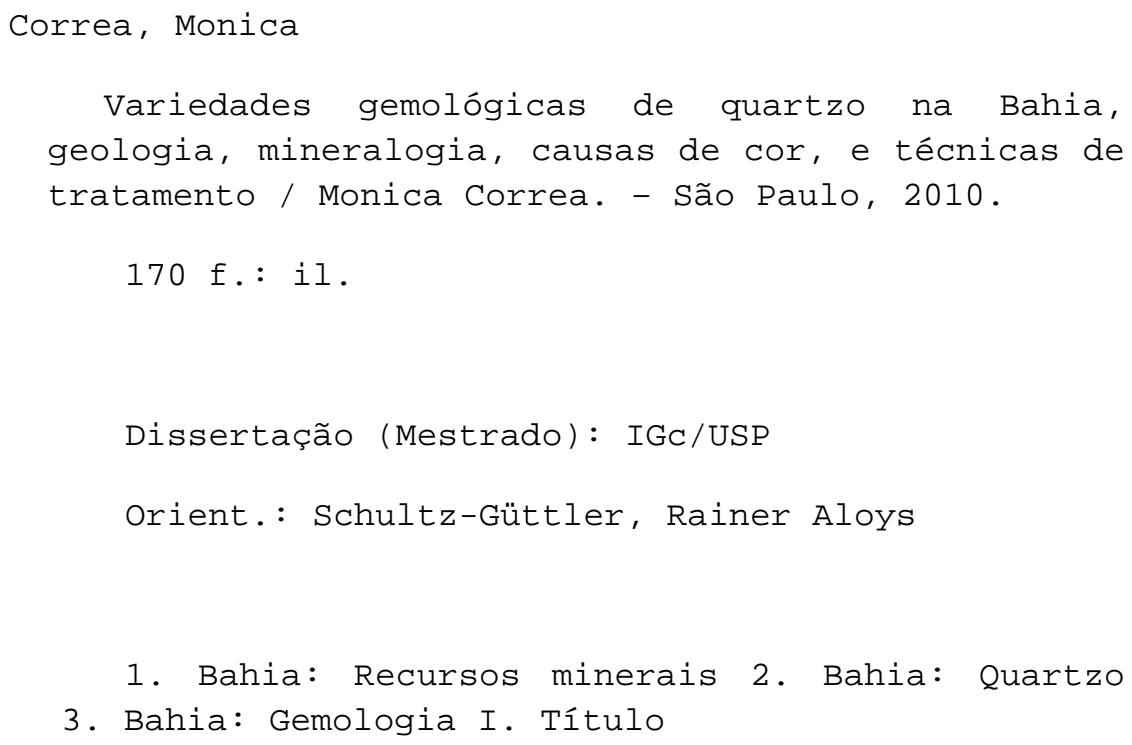


Dedico esta Dissertação ao meu amado mestre Vilton Fernandes de Jesus, por toda inspiração, admiração, ensinamentos, e incansável presença. 


\section{AGRADECIEMNTOS}

Agradeço primeiramente a Deus, a meu amado pai Edson José Correa e as minhas “mães" Lucia Helena Matozo Correa, Aparecida Guimarães e Edna Kratz Poli, por todo amor, carinho, dedicação, compreensão, incentivo e paciência diária; Aos meus avós Edwards Matozo e Ruth da Silva Matozo, pelas boas vibrações e energia de sempre; Aos meus "irmãos" Ana, Bruno e Marco, por me acolher em sua família e me aturar dia-a-dia. Aos meus familiares e amigos, pela compreensão da minha ausência; Ao sr. Paulo Sebastião de Jesus, pelos ensinamentos; A dra. Mariá Silva Souza.

Aos Meus orientadores e amigos, Rainer Aloys Schultz Güttler, e Vilton Fernandes de Jesus, pela dedicação, aprendizado, empenho e confiança.

A geóloga Simone C. Pereira Cruz, por me ensinar a ser guerreira, e acreditar que posso ir sempre além; A gemóloga e amiga Grácia Baião, por toda dedicação, incentivo, carinho, prestatividade e amizade; A Heli de A. Sampaio Filho, Jorge Luiz Nunes, Gustavo Carneiro, Solange d'Ávila, e toda eterna equipe do Museu Geológico da Bahia.

O meu agradecimento mais do que especial aos meus grandes amigos, Elizandra Pinheiro, Ingrid Negrão, Manuela Maia, Carlos Henrique Balogh, Matheus Fonseca, e Tiago Ximenes, pela amizade, companheirismo, carinho, paciência, atenção, lealdade, e principalmente por estarem comigo onde for. Amo vocês.

Aos professores de geociências Daniel Atencio, Fabio R. D. de Andrade, Gergely A. J. Szabó, José M. V. Coutinho, José B. Madureira Filho, Darci P. Svízzero, Sílvio R. F. Vlach, dentre outros, pelos ensinamentos adquiridos; As funcionarias da secretaria de pósgraduação Ana Paula e Magali, por toda prestatividade e colaboração; A todos os funcionários da Biblioteca da USP; Aos amigos e colegas da pós-graduação Tatiana, Ângela, Frederico, Felix, Diana, Ideval, pela companhia agradável, momentos de descontração, apoio e incentivo diário; A CAPES, Coordenação de Aperfeiçoamento de Pessoal de Nível Superior e USP, por todo auxílio necessário para o desenvolvimento deste trabalho.

Aos integrantes da Cooperativa Mista Agropecuária e de Mineração de Brejinho das Ametistas - COOMAC, Agnaldo e Floriano, ao Prospector Silvestre e a Fernando e Sabino, de Jacobina.

Ao meu anjo da guarda e aos bons espíritos que sempre me acompanham; Ao meu computador, fiel companheiro dos dias, noites e madrugadas; e a força vinda das águas de Yemanjá. 
"A inspiração tem um toque de magia, porque é uma coisa absoluta, inexplicável. Não creio que venha de fora para dentro, de forças sobrenaturais. Suponho que emerge do mais profundo eu da pessoa, do inconsciente individual, coletivo e cósmico."

"A possibilidade de realizarmos um sonho é o que torna a vida interessante"

(Clarice Lispector) 


\section{RESUMO}

CORREA, M. Variedades gemológicas de quartzo na Bahia, geologia, mineralogia, causas de cor, e técnicas de tratamento. 2010. 170f. Dissertação (Mestrado) - Instituto de Geociências, Universidade de São Paulo, São Paulo, 2010.

A Bahia tem sido, juntamente com Minas Gerais, Goiás e Rio Grande do Sul, destaque na produção de gemas naturais do Brasil, pais que detém grande parte das reservas mundiais desses bens minerais, com produção de gemas de qualidade reconhecidas internacionalmente. Os controles estatísticos registram a presença de mais de trinta variedades gemológicas em território baiano (Tavares et al, 1998). O quartzo é utilizado ultimamente em grande escala na produção de jóias. Isto se deve a sua grande abundância no território baiano, preços relativamente baixos de exploração, e a boa resposta do mesmo aos tratamentos térmico e de irradiação gema, visando mudanças ou o melhoramento da cor. As Serras do Espinhaço Setentrional e de Jacobina, bem como a região da Chapada Diamantina, concentram a maior parte das ocorrências de variedades, tanto coloridas como susceptíveis ao tratamento para induzir cor, deste mineral, o qual passou a ser visto como uma das principais matérias-prima para lapidários, comerciantes e joalheiros da região. Apesar da importância das mineralizações, existe uma carência de estudos científicos que abordem questões relacionadas com a evolução e controle geológico das mineralizações e com os tratamentos que são realizados para melhorar o potencial gemológico das regiões estudadas. Tendo em vista enriquecer 0 conhecimento deste potencial geológico do território baiano, a realização deste estudo representa um passo significativo no entendimento da evolução metalogenética das áreas estudadas, além de contribuir com o estudo geológico e gemológico das variedades coloridas do quartzo na Bahia. Os quartzos gemológicos estudados na Bahia encontram-se inseridos principalmente em ambientes hidrotermal, encaixados em rochas metareníticas e quartziticas do Supergrupo Espinhaço. A partir dos dados levantados em campo, pôde-se verificar que as mineralizações estudadas possuem um controle estrutural, e encontram-se posicionadas em fraturas de tração de baixo ângulo. Tais fraturas estão associadas com rampas de empurrão que se desenvolveram durante as deformações que culminaram com a estruturação do cinturão de dobramentos e cavalgamentos da Serra do Espinhaço. A cor da ametista é devido a presença de impurezas derivadas da família do ferro $\left(\mathrm{FeO}_{4}\right)^{-4}$, e da radiação ionizante. O quartzo fumê desenvolve-se apenas com a presença de alumínio e lítio, e o fenômeno do "centro de cor" (defeito na estrutura cristalina causada pela falta de um elétron) é o responsável pela sua cor, onde o íon $\mathrm{Al}^{3+}$ ao substituir o íon $\mathrm{Si}^{4+}$ gera um desequilíbrio eletrônico que é compensado por íons de Li. O citrino por sua vez, deve sua cor a uma combinação de AI-Li, semelhante ao do quartzo fumê. Os estudos também demonstraram que as aquisições de cores no quartzo obtidas através dos processos de irradiação gama e tratamento térmico, bem como a estabilidade das mesmas, estão amplamente condicionadas aos ambientes de formação dos cristais, e a presença de elementos químicos nos fluidos formadores dos cristais, os quais são responsáveis pela variação de suas cores. As características gemológicas encontradas demonstram que o quartzo baiano apresenta um elevado potencial comercial. Para o futuro sugere-se trabalhos de levantamentos geológicos e pesquisa mineral, desde que a exploração das gemas vem apresentando significativas reduções e limitações nas suas atividades minero-industriais, seja pela parcial exaustão das reservas conhecidas, ou pela necessidade de ampliá-las e, assim, incentivar novos investimentos. Pouquíssimos trabalhos com cunho gemológico tem sido publicados no Brasil com vista de esclarecer a correlação entre depósitos de quartzo e seu comportamento perante tratamentos de irradiação e de aquecimento.

Palavras-chave: Bahia; Recursos Minerais; Quartzo; Gemologia 


\begin{abstract}
CORREA, M. Gemology quartz of Bahia, geology, mineralogy, causes of color, and treatment. 2010. 170f. Dissertação (Mestrado) - Instituto de Geociências, Universidade de São Paulo, São Paulo, 2010.
\end{abstract}

Besides Minas Gerais, Goiás and Rio Grande do Sul, Bahia is worldwide known for its richness in minerals of industrial and gemological interest. Up to this day, more than 30 minerals of gemological use are known (Tavares et. al. 1998) One of the main gemological material is quartz, used currently in large amounts for jewelry due to its fair value and good response of color treatments by irradiation and heat. Most of the quartz is found and mined in the Espinhaço, Chapada Diamantina and Jacobina belts either as colorless quartz or as amethyst. The colorless variety is sometimes prone to treatments that induce color centers resulting in black (Morion), brown (Smoky), yellow(Citrine), green ("Prasiolite") gemstones. Very few work exists dealing with the geological evolution, control of mineralization, estimation of quantities and possible treatments of these materials. The results of this work is a contribution to the knowledge of the metalogenic evolution of the studied areas and includes the location of all known occurrences of quartz from Bahia. It could be shown that most of the quartz from Bahia state is located mainly in a hydrothermal environment crosscutting the quartzites and arkosic rocks of the Espinhaço Supergroup. Field data showed strong tectonic control of the quartz veins, filling low angle traction fractures associated with the thrust belts that formed the Serra do Espinhaço mountain range. The fluids passing through these fractures deposited quartz, as amethyst (Breijinho de Ametista, Jacobina e Sento Sé), colorless and milky quartz and sometimes as citrine. The color of amethyst is due to substitutional iron with oxidation degree 4+, formed by irradiation of ferric iron contained in the tetrahedral of the quartz structure. Smoky colors are formed by irradiation of mainly Al containing quartz, whereas yellow and yellow green colors are formed by the presence of $\mathrm{Al}$ and Li. Few occurrences of colorless quartz forming a green variety by irradiation have been documented. Some preliminary results show that the type and intensity of color is determined by the specific environment of formation. More work is clearly needed to clarify the correlation of formation environment and color produced by irradiation and heat treatments.

Keywords: Bahia; Minerals Resources; Quartz; Gemology 


\section{LISTA DE FIGURAS}

Figura 1.1: a) Cráton do São Francisco e suas faixas marginais. Fonte: Cruz (2004). b) Áreas legais de garimpagem e mineração de Gemas do estado da Bahia, com ênfase para a Província do Paramirim. Fonte: Misi et. al. (2000). Modificado a partir de Almeida (1977), Cruz (2004), Misi et al. (2006) e Cruz \& Alkmim (2006), a partir dos quais são apresentados os limites do Cráton do São Francisco e da Província do Paramirim.

Figura 1.2: Principais áreas produtoras de quartzo na Bahia, região da Chapada Diamantina e da Serra do Espinhaço Setentrional. Modificado de Loureiro (2009).

Figura 2.1: Mapa de Ocorrências de quartzo e suas variedades coloridas no Estado da Bahia.

Figura 2.2: gráfico de solubilidade do quartzo em água pura, com gradiente geotermobárico de $35^{\circ} \mathrm{C}$ e 300 bar/Km. Fonte: Fyfe et . al, (1978).

Figura 2.3: Diagrama esquemático das zonas de solubilidade do quartzo e sua consequente migração para as zonas mais permeáveis relativas à falhamentos; seguido do zoneamento dos veios de quartzo, onde 1 é a Zona de Borda; 2 a Zona brechóide, 3 a Zona maciça, 4 a Zona mais cristalina (central). Modificado de Favacho-Silva, (2000).

Figura 3.1: Subdivisões da Serra do espinhaço segundo quatro domínios principais: Espinhaço Meridional, Espinhaço Central, Espinhaço Setentrional, e Chapada Diamantina. Fonte: Modificado de Chaves, 1997.

Figura 3.2: Mapa tectônico simplificado da porção leste do Brasil, enfatizando o Cráton do São Francisco, o Aulacógeno do Paramirim e a Faixa Araçuaí. Fonte: Cruz (2004).

Figura 3.3: Três blocos Arqueanos no embasamento do São Francisco. Estão assinaladas em cores, as rochas paleoproterozóicas e em branco, as rochas Arqueanas. Zonas de colisão e o sentido dos empurrões são também colocados. Fonte: (Barbosa \& Sabaté 2004).

Figura 3.4: Mapa Geológico simplificado do Aulacógeno do Paramirim, enfatizando as principais unidades geológicas e estruturas tectônicas de idade brasiliana. BGBloco Gavião, BJ- Bloco Jequié, ES- Espinhaço Setentrional, CD- Chapada Diamantina, SRP- Saliência do Rio Pardo (Faixa Araçuaí). Mapa construído a partir de Schobbenhaus et al. (1981) e Barbosa \& Dominguez (1996). Fonte: Cruz (2004).

Figura 3.5: Coluna estratigrafica esquemática mostrando embasamento, principais sistemas deposicionais e ambientes tectônicos dos Grupos Borda Leste, Espinhaço Setentrional e Complexo Licínio de Almeida. Fonte: Rocha (1991).

Figura 4.1: Principais Regiões Produtoras/Potenciais de Gemas do Estado da Bahia. Modificado de Couto et. al. (2000). Modificado a partir de Carvalho Filho (1976), Cruz (2004), Misi et al. (2006) e Cruz \& Alkmim (2006).

Figura 4.2: Distribuição Quantitativa dos jazimentos da Bahia (em \%). Fonte Couto et. al, 2000 
Figura 4.3: Mapa Geológico simplificado mostrando as ocorrências de Ametista, Ferro e Manganês da região

Figura 4.4: Perfil Geológico Esquemático da região de Brejinho das Ametistas construído a partir dos dados de campo

Figura 4.5: Diagramas estereográficos sinópticos para o conjunto de estruturas recuperadas na Mina Paraguai, Hemisfério inferior. N= Número de medidas.

Figura 4.6: Síntese dos dados estruturais em diagramas estereográficos sinópticos

Figura 4.7: Modelo Estrutural das Fraturas de Tração em Zonas de Cisalhamento Compressionais

Figura 4.8: Planta da mina de ametista da Grota do Coxo. Fonte: Schobbenhaus et. al, (1991)

Figura 5.1: Projeção da Estrutura de um cristal de Quartzo em um eixo "c". Fonte: Akahavan, (2005).

Figura 5.2: Célula Unitária (azul) e eixos cristalográficos projetados em um cristal de quartzo. Fonte: Akahavan, (2005).

Figura 5.3: modelo de um cristal de quartzo Fonte: Akahavan, (2005).

Figura 5.4: Vista superior do modelo de cristal de quartzo Fonte: Akahavan, (2005).

Figura 5.5: Tetraedros de $\mathrm{Si}^{4+}$ e $\mathrm{O}^{2-}$, com seus respectivos raios iônicos. Fonte: Akahavan, (2005).

Figura 5.6: Ligação Tridimensional de tetraedros de $\mathrm{SiO}_{4}$. Fonte: Akahavan, (2005).

Figura 5.7: Arranjo Hexagonal de tetraedros de $\mathrm{SiO}_{4}$, átomos de silício são de cor branca e átomos de oxigênio são de cor vermelha. . Fonte: Akahavan, (2005).

Figura 5.8: O ângulo central formado pelos átomos de O-Si-O é muito próximo ao valor ideal de um tetraedro (109,5 9. Fonte: Akahavan, (2005).

Figura 5.9: Ligação entre dois tetraedros de $\mathrm{SiO}_{4}$. Fonte: Akahavan, (2005).

Figura 5.10: Rede de tetraedros

Figura 5.11: Morfologia dos cristais de quartzo direito e esquerdo. As faces menores são X, S e Z, localizadas à esquerda do observador no quartzo esquerdo, e à direita, no quartzo direito. Fonte: Akahavan, (2005).

Figura 5.12: Tipos de geminação encontrados em cristais de quartzo, da Bahia; a) geminação do Brasil, b) geminação Lei de Dauphiné, c) geminação Leio do Japão. Modificado de Dana \& Hurlbut, (1969)

Figura 5.13: Representações das estruturas poliédricas do quartzo (a) e da tridimita e cristobalita (b) Fonte: Dana (1979)

Figura 5.14: Diagrama dos campos de estabilidade em função da $\mathrm{P}$ e $\mathrm{T}$ das fases polimórficas de sílica. Fonte: Klein (1993) 
Figura 6.1: 0 espectro eletromagnético. O quartzo absorve comprimentos de ondas dentro da faixa dos espectros visível, ultravioleta e infravermelho. O espectro visível abrange a faixa que vai de $375 \mathrm{~nm}$ a aproximadamente $740 \mathrm{~nm}$. Modificado de Klein (2002).

Figura 6.2: Diagrama de Cromaticidade (XYZ), onde A variável $Y$ corresponde ao brilho, enquanto que as variáveis $\mathrm{X}$ e $\mathrm{Z}$ se referem ao tom e a saturação.

Figura 6.3: Desenho esquemático do espectro de absorção de luz por um mineral. Quando um cristal absorve luz, os elétrons são levados de um nível de baixa energia (estado de repouso), a um nível de alta energia (estado de excitação). Essa energia perdida é dissipada na forma de calor ou luminescência, ao elétron voltar ao seu estado de repouso. Fonte Fritsch \& Rossman, (1987).

Figura 6.4: Principais Impurezas responsáveis pela coloração do Quartzo. Fonte Castaneda (2001).

Figura $6.5 \mathrm{a}$, b: Desenho ilustrativo comparativo das estruturas dos quartzos hialino e enfumaçado. Fonte: Klein et. al, (1993).

Figura 6.6: Variedades coloridas da ametista obtidas através de tratamento térmico. Citrino (amarelo) e Prasiolita (verde).

Figura 6.7: Formação do centro de cor no quartzo: a) Molécula de $\mathrm{SiO}_{2}$ (quartzo incolor) antes da irradiação, b)Depois da irradiação, nos locais onde o $\mathrm{Si}^{4+}$ é substituído pelo $\mathrm{Al}^{3+}$. Existe um desequilíbrio eletrônico (falta de uma carga positiva) em que o restabelecimento ocorre com a retirada de um elétron (Fonte: Nassau, 1984)

Figura 6.8: Principais impurezas responsáveis pela coloração do quartzo. Modificado de Castaneda (2001). 


\section{LISTA DE TABELAS}

Tabela 3.1: Correlação geológica entre Espinhaço Setentrional e Chapada Diamantina, Segundo Danderfer fo (2000)

Tabela 3.2: Principais dados geocronológicos das rochas do Supergrupo Espinhaço. Fonte: Martins (2008)

Tabela 3.3: Propostas de colunas estratigráficas para o Supergrupo Espinhaço na Chapada Diamantina/BA. Fonte: Martins (2008)

Tabela 5.1: características morfológicas, estruturais e ópticas do quartzo esquerdo e direito

Tabela 6.1: Fatores para a formação das variedades macrocristalina e criptocristalina do quartzo 


\section{LISTA DE FOTOGRAFIAS}

Foto 4.1: Vista geral do garimpo da Brauninha

Foto 4.2: Detalhe do depósito mostrando os seixos de quartzitos no Garimpo Brauninha

Foto 4.3: Boca da Mina do Paraguai

Foto: 4.4: Mineralizações de ametistas encaixadas em fraturas de tração nos quartzitos da Formação Salto, na Mina Paraguai

Foto 4.5: Amostras de ametista, quartzo fumê e citrino (ametista queimada) da Mina do Paraguai, Brejinho das Ametistas/BA.

Foto 4.6: Amostras de ametista da Mina da Bolívia, Brejinho das Ametistas/BA.

Foto 4.7: Vista da entrada da Mina Paraguai, Caetité-BA

Foto 4.8: Vista parcial das "grunas" do garimpo da serra do Salto, Licínio de Almeida-BA

Foto 4.9: seleção manual para eliminação da impregnação de hematita na ametista

Foto 4.10: Detalhe dos cristais de Ametista de coloração violeta intenso na mina Paraguai, Brejinho das Ametistas/BA.

Foto 4.11: Arranjo Radial da lineação de crescimento dos cristais de ametista, da mesma localidade.

Foto 4.12: Fraturas de tração (Fr) mineralizadas encaixadas em rochas metareníticas da Formação Salto (Supergrupo Espinhaço).

Foto 4.13: Cristal de ametista com $12 \mathrm{~cm}$

Foto 4.14: zoneamento de cor, onde na borda os cristais são de quartzo hialino e no centro de ametista

Foto 4.15: veios de quartzo leitoso cortando fraturas.

Foto 4.16: zonas ferruginosas associadas à domínios de intenso fraturando

Foto 4.17 e 4.18: cristais de quartzo rutilado da região de Oliveira dos brejinhos/BA, bruto e lapidado, respectivamente.

Foto 4.19: Drusas de Cristal-de-rocha, explorados de forma artesanal, no garimpo São Pedrinho, Oliveira dos Brejinhos/BA. Fonte: Loureiro (2009).

Foto 4.20: Extração de cristal-de-rocha, de forma rudimentar, em depósitos eluvionares, na região de Macaúbas-BA. Fonte: Couto (2000).

Foto 4.21: cristais de quartzo hialino de qualidade gemológica

Foto 4.22: mineralizações, de veios de quartzo hidrotermal cortando as camadas das seqüências sedimentares. Fonte: Loureiro (2009). 
Fotos 4.23 e 4.24: cristais de quartzo rutilado associados ao quartzo hialino, da região de Ibitiara e Novo Horizonte, Chapada Diamantina/BA

Foto 4.25: metarenitos da Formação Tombador, base do Grupo Chapada Diamantina, da região de Sento Sé/BA. Fonte Loureiro (2009).

Fotos 4.26 e 4.27: cristais de ametistas de boa qualidade, de coloração roxa intensa, provenientes da região de Sento Sé/BA

Foto 4.28: cristais de citrino natural de boa qualidade, provenientes da região de Sento Sé/BA

Foto 4.29: ametistas em forma de cavidades ovóides, localmente conhecidas por "vugs"

Foto 4.30: marcas de ondas preservadas nos quartzitos da Formação Rio do Ouro, Grupo Jacobina.

Foto 4.31: drusa de Hematóide da mina do Coxo, Jacobina/BA

Fotos 4.32 e 4.33: zoneamento de cores arranjadas perpendicularmente ao eixo "c", em cristais de ametistas da Mina do Coxo, Jacobina/BA.

Fotos 4.34 e 4.35: zoneamento de cores e linhas de crescimento, em cristais de quartzo fumê da Mina do Coxo, Jacobina/BA.

Fotos 4.36 e 4.37: cristais de ametista de boa qualidade, da Mina do Coxo, Jacobina/BA

Foto 4.38: Garimpeiros na Mina do Coxo, em meados de 1976, quando ela se encontrava em plena atividade

Foto 5.1: Cristais de Tridimita

Foto 5.2: Cristais de Cristobalita

Fotos 5.3, 5.4, 5.5, 5.6: Inclusões mais comumente encontradas no quartzo; turmalina, hematita, gohetita, rutilo, respectivamente.

Fotos 6.1 e 6.2: cristais de quartzo hialino de qualidade gemológica

Fotos 6.3 e 6.4: cristais de ametistas de qualidade gemológica, de diversas tonalidades

Fotos 6.5 e 6.6: Cristais de citrino provenientes de ametista termicamente tratada

Foto 6.7: Cristais de citrino de ocorrência natural

Fotos 6.8 e 6.9: Cristais de citrino natural submetidos ao tratamento térmico para melhoramento de sua cor.

Fotos 6.10 e 6.11: Cristais de quartzo fumê e morion, respectivamente

Foto 6.12: Cristais de quartzo fumê apresentando asterismo.

Foto 6.13: Cristal de quartzo rosa de aparência maciça. 
Fotos 6.14 e 6.15: Cristais de quartzo rosa natural e submetido a irradiação gama, respectivamente

Fotos 6.16 e 6.17: Cristais de green gold da região de São José da Safira/MG

Fotos 6.18 e 6.19: cristais de prsiolita nas formas bruta e lapidada, respectivamente

Fotos 6.20 e 6.21: Cristais de quartzo verde produzidos através de irradiação gama em quartzo hialino, da região de Macaúbas/BA.

Foto 6.22: Filtro Chelsea

Foto 6.23: Cristais de prasiolita e quartzo verde vistos a olho nu.

Foto 6.24: Cristais de prasiolita e quartzo verde, vistos através do filtro Chelsea.

Foto 6.25: Cristais de quartzo azul e prasiolita, respectivamente.

Fotos 6.26 e 6.27: Cristais de quartzo azul de ocorrência natural.

Foto 6.28: Cristal de quartzo Leitoso

Foto 6.29 e 6.30: Cristais de hematóide da mina Grota do Coxo, Jacobina/BA.

Foto 6.31: inclusões fluidas tipo listas de tigre

Foto 6.32: inclusões de goethita, em forma cogumelo

Foto 6.33: marcas de geminação na superfície do cristal de citrino de ocorrência natural

Foto 6.34: cristal de ametrino de qualidade gemológica

Foto 6.35: cristal de ametrino com inclusões fluidas e microfraturas

Fotos 6.36 e 6.37: cristal de quartzo fumê com presença de inclusões leves dos tipos bifásica, e cristais negativos, respectivamente

Foto 6.38: inclusões fluidas tipo listas de tigre

Foto 6.39: inclusões de goethita

Foto 6.40: cristal de hematóide

Foto 6.41: inclusões de hematita em forma de agulhas

Foto 7.1: Cristais de citrino natural

Foto 7.2: cristais de citrino irradiados

Foto 7.3: Cristais de quartzo hialino irradiados e naturais, repectivamente

Foto 7.4: Lascas de citrino resultante da "queima" da ametista. Serra do Salto, Licínio de Almeida-BA. Fonte: (Couto et al, 2000) 
Foto 7.5: Estufas para a "queima" da ametista, Lavra do Salto, Licínio de AlmeidaBA. Fonte: (Couto et al,2000)

Foto 7.6: Cristais de citrino produzidos através de tratamento térmico em ametista da região de Jacobina

Foto 7.7: Cristais de citrino produzidos através de tratamento térmico em ametista da região de Brejinho das Ametistas.

Foto 7.8: cristais de citrino de Sento Sé, após irradiação e tratamento térmico 


\section{SUMÁRIO}

1. INTRODUÇÃO 1

1.1. Contextualização e Apresentação do Problema 3

1.2. Objetivos e Metas 4

1.3. Área de Trabalho 4

1.4. Justificativa 6

1.5. Metodologia de Trabalho 6

2. QUARTZO NA BAHIA 8

2.1. Introdução 8

2.2. Aspectos Geológicos 9

2.2.1. Ambiente de Formação e Formas de Ocorrência 10

2.2.2. Tipologia dos Depósitos de Quartzo na Bahia 11

2.2.3 Ocorrências de Quartzo na Serra do Espinhaço 12

2.3. Aspectos Econômicos 16

2.4. Aspectos Tecnológicos 18

2.5. Aspectos Sociais 19

3. CONTEXTO GEOLÓGICO REGIONAL 20

3.1. Serra do Espinhaço 20

3.1.1. O Espinhaço Setentrional 22

3.1.1.1. Unidades Litoestratigráficas $\quad 24$

3.1.2. Chapada Diamantina 30

3.1.2.1. Unidades Litoestratigráficas $\quad 31$

3.1.3. Jacobina 34

4. CONTEXTO GEOLÓGICO LOCAL 36

4.1. Introdução 36

4.2. Tipologia dos Depósitos de Quartzo na Bahia 37

4.2.1. Depósitos Coluvionais 37

4.2.2. Depósitos Epigenéticos 38

4.3. O Quartzo na Serra do Espinhaço Setentrional 38

4.3.1. Depósitos Estudados 39

4.3.1.1. Brejinho das Ametistas e Serra do Salto 39

4.3.1.1.1. Caracterização Geológica e Estrutural da Mineralização 45

4.3.1.2. Oliveira dos Brejinhos $\quad 49$

4.3.1.3. Macaúbas $\quad 52$

4.4. O Quartzo na Chapada Diamantina 52

4.4.1. Depósitos Estudados 53

4.4.1.1. Chapada Diamantina 53

4.4.1.2. Sento Sé $\quad 55$

4.5. O Quartzo em Jacobina 58

5. CARACTERÍSTICAS MINERALÓGICAS 64

5.1. Introdução 64

5.2. Propriedades Físicas e Ópticas 64

5.3. Propriedades Químicas 66

5.4. Estrutura Cristalina 67 
5.5. Hábito 71

5.6. Geminação 72

5.7. Principais Polimorfos

5.8. Inclusões $\quad 75$

5.9. Aplicações $\quad 77$

6. VARIEDADES COLORIDAS DO QUARTZO MACROCRISTALINO 80

6.1. Introdução 80

6.2. Origem da Cor 81

6.3. Cristal-de-rocha/ Quartzo Hialino 86

6.4. Ametista 87

6.5. Citrino 90

6.6. QuartzoFumê/ Morion 92

6.7. Quartzo Rosa 95

6.8. Green Gold 97

6.9. Prasiolita/ Ametista Verde 98

6.10. Quartzo Verde 98

6.11. Quartzo Azul 100

6.12. Quartzo Leitoso 101

6.13. Quartzo Hematóide 102

6.14. Influência do Ambiente Geológico 102

6.14.1. Introdução 102

6.14.2. Quartzo Fumê 103

$\begin{array}{ll}\text { 6.14.3. Ametista } & 104\end{array}$

6.14.4. Citrino 104

6.15. Características Gemológicas 105

7. TÉCNICAS DE BENEFICIAMENTO UTILIZADAS 110

7.1. Irradiação Gama 110

7.2. Tratamento Térmico 112

7.3. Leis e Órgãos de Controle de Comercialização de Gemas 115

8. CONCLUSÕES 117

9. REFERÊNCIAS BIBLIOGRÁFICAS 121

10. ANEXO 132 


\section{INTRODUÇÃO}

O Brasil foi atestado pelo Gemological Institute of America (GIA), como um dos maiores produtores de pedras preciosas (gemas) do mundo, apresentando uma produção que se caracteriza, principalmente, por uma enorme variedade gemológica (Tavares et. al, 1998). De acordo com aqueles autores, a Bahia tem sido juntamente com Minas Gerais, Goiás e Rio Grande do Sul, destaque na produção de pedras preciosas naturais do Brasil, país que detém grande parte das reservas mundiais desses bens minerais com produção de gemas de qualidade reconhecidas internacionalmente.

Svisero \& Franco (1991) assinalaram que nas décadas passadas houve um extraordinário desenvolvimento das atividades gemológicas, provocado essencialmente pela expansão do comércio internacional das pedras preciosas. Com isso, de acordo com os autores acima citados, houve um aumento nas investigações por novos depósitos de gemas, gerando uma grande corrida para novas descobertas de jazimentos em diversos países. Neste contexto tem-se como bons exemplos brasileiros, os depósitos de gemas da Bahia. Esta riqueza mineral se deve ao fato do território baiano encontrar-se inserido no contexto do Cráton do São Francisco, cujo substrato e suas referentes coberturas foram submetidos a uma evolução geológica complexa, a qual favoreceu o desenvolvimento de mineralizações diversificadas, tendo um especial destaque para as gemas.

De acordo com o Couto et. al. (2000), dentre os mais de 700 registros de jazimentos no Estado da Bahia, alguns depósitos de quartzos e suas variedades se destacam pela sua importância econômica, sendo eles os depósitos de ametista em Brejinho das Ametistas e Jacobina, depósitos de cristal-de-rocha (quartzo hialino) em domínios da Chapada Diamantina e do Supergrupo Espinhaço, e depósitos de citrino na Serra do Salto e Sento Sé. Segundo os mesmos autores, embora exista uma grande diversidade de recursos gemológicos na Bahia, os realces produtivos atuais, e nas últimas três décadas, continuam sendo a esmeralda, a ametista e água-marinha. 


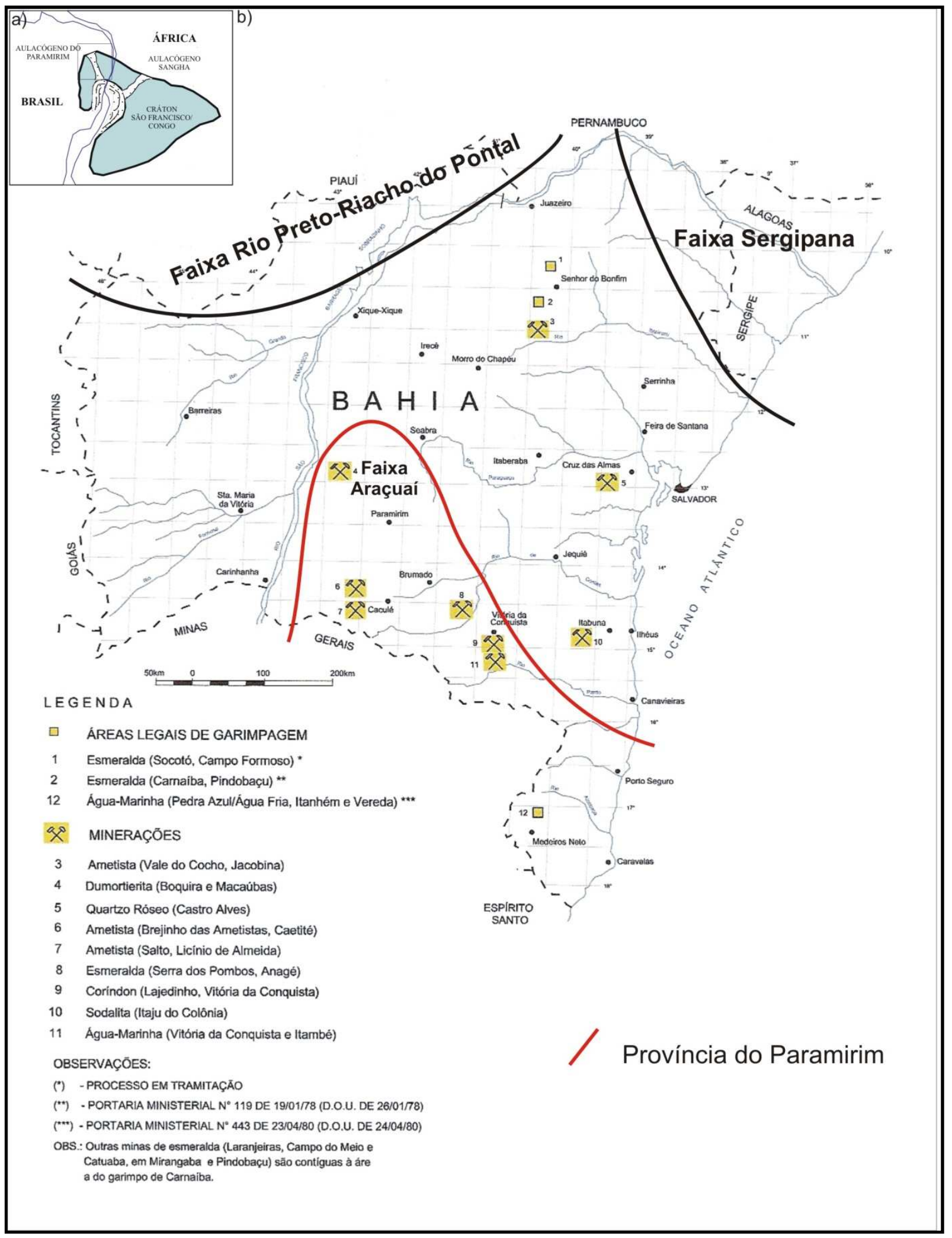

Figura 1.1: a) Cráton do São Francisco e suas faixas marginais. Fonte: Cruz (2004). b) Áreas legais de garimpagem e mineração de Gemas do estado da Bahia, com ênfase para a Província do Paramirim. Fonte: Misi et. al. (2000). Modificado a partir de Almeida (1977), Cruz (2004), Misi et al. (2006) e Cruz \& Alkmim (2006), a partir dos quais são apresentados os limites do Cráton do São Francisco e da Província do Paramirim. 
Segundo Favacho (2001), e Guttler (2007), o quartzo é utilizado ultimamente em grande escala na produção de jóias. Isto se deve á facilidade de tratamentos, principalmente com a radiação gama, e às cores resultantes destes tratamentos, podendo se obter as cores marrom, amarelo, amarelo-esverdeado, verde, verde oliva, laranja e mesmo vermelho, como cores atrativas de quartzo. Ainda de acordo com os autores citados, o comportamento do quartzo de cada região, em fase do tratamento, é diferente. As condições de formação e a presença de vários elementos químicos nos fluidos formadores dos cristais de quartzo são responsáveis pela diversidade de cores.

Pouquíssimos trabalhos com cunho gemológico têm sido publicados no Brasil, com vista de esclarecer a correlação entre depósitos de quartzo e comportamento do mesmo perante os tratamentos de irradiação e de aquecimento.

\subsection{Contextualização e Apresentação do Problema}

A Bahia destaca-se na produção gemológica nacional, mas, apesar do elevado potencial, poucos foram os estudos a cerca da evolução metalogenética dos seus depósitos, assim como das suas características gemológicas essenciais, capazes de atrair investimentos empresariais e cooperativados dirigidos para a pesquisa e extração de gemas, com desdobramentos nos seguimentos de beneficiamento e comercialização das mesmas, podendo gerar conseqüentes ganhos socioeconômicos e empresariais.

A grande maioria dos depósitos de quartzo e suas variedades no estado da Bahia localizam-se ao longo do Cinturão de Dobramentos e Cavalgamentos da Serra do Espinhaço. Embora sejam depósitos conhecidos desde a segunda metade do século passado, há um completo desconhecimento a cerca do controle geológico, assim como das propriedades gemológicas de suas gemas.

Diante do exposto, surgem as seguintes questões:

a) Qual o controle geológico dos depósitos de quartzo na Serra do Espinhaço? 
b) Quais as suas propriedades gemológicas, assinatura geoquímica, e causa de cor?

c) Quais os métodos de tratamentos empregados?

d) Qual a reação das suas gemas, aos tratamentos de beneficiamento empregados?

Responder a essas perguntas constitui o foco principal deste trabalho que contribuirá para o entendimento do contexto geológico das mineralizações em questão.

\subsection{Objetivos e Metas}

Este trabalho é de caráter experimental, e tem como objetivo mapear e analisar as ocorrências de quartzo e suas variedades coloridas, sua geologia, mineralogia, tipologia dos depósitos, causas de cor e a influência do ambiente geológico nas mudanças de sua cor, no Estado da Bahia, e posteriormente, verificar a possibilidade de utilização do quartzo das jazidas baianas para a produção de gemas coradas, através de técnicas de tratamento como aquecimento e irradiação. Assim, o projeto se encaixa nos esforços do governo baiano de Desenvolvimento Mineral (Projeto de Lei16786/ 2007) visando a criação de ações e projetos de incentivo à produção, lapidação e comercialização de pedras preciosas, artesanatos, jóias e bijuterias, bem como enriquecer o conhecimento deste potencial geológico do território baiano.

\section{3. Área de Trabalho}

O presente estudo abrange as áreas localizadas principalmente nos domínios do Supergrupo Espinhaço, com destaque para a Serra do Espinhaço na sua porção Setentrional (Brejinho das Ametistas/Caetité, Serra do Salto/Licínio de Almeida, Macaúbas e Oliveira dos Brejinhos), bem como a Chapada Diamantina (Ibitiara, Novo Horizonte, Sento Sé), além da Serra de Jacobina (Jacobina). 


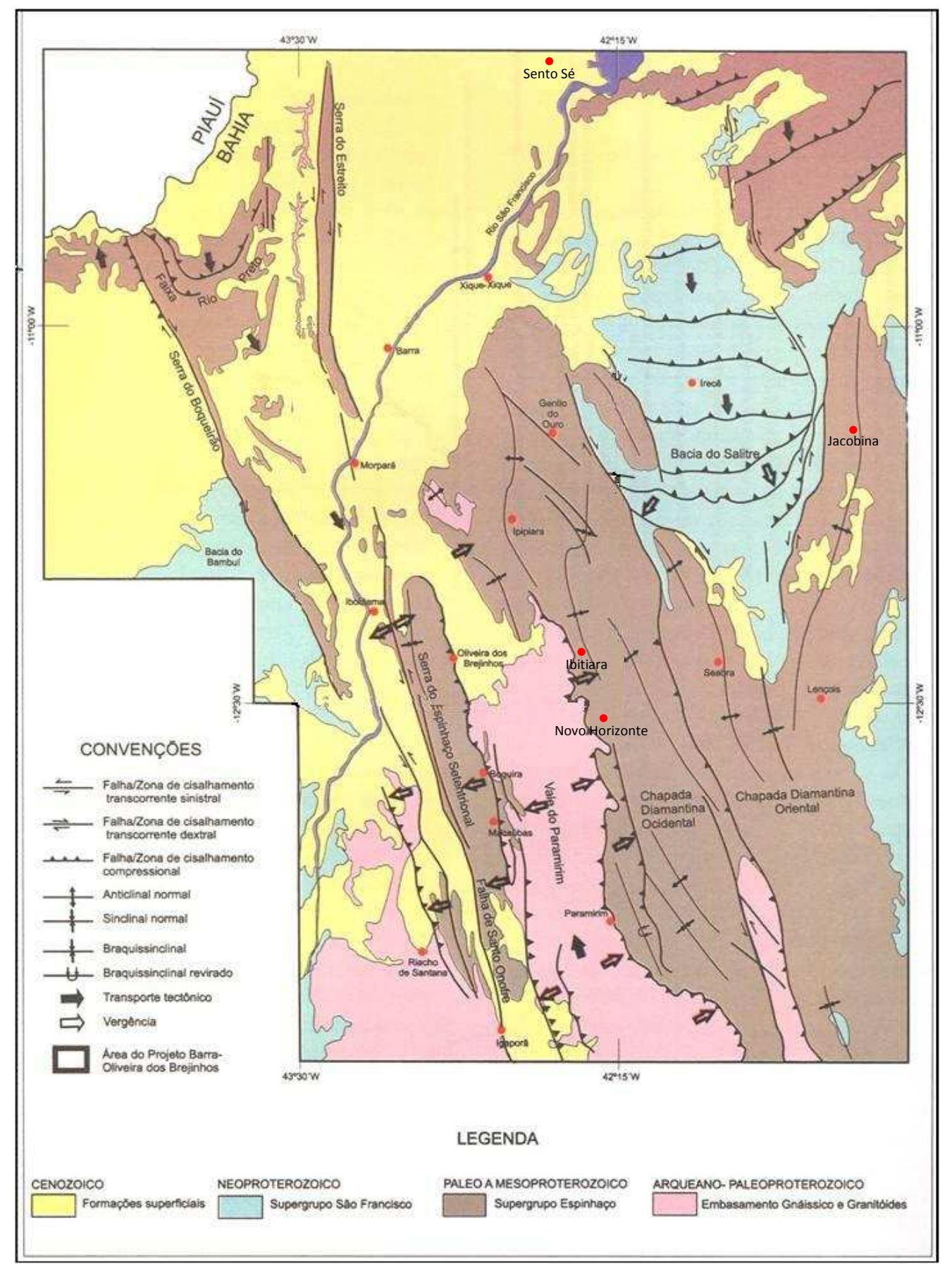

Figura 1.2: Principais áreas produtoras de quartzo na Bahia, região da Chapada Diamantina e da Serra do Espinhaço Setentrional. Modificado de Loureiro (2009).

\subsection{Justificativa}

O Estado da Bahia é o quarto produtor de gemas do país. Entretanto, como já mencionado anteriormente, poucos foram os estudos abordando os aspectos 
geológicos e gemológicos dos principais distritos gemológicos baiano. O entendimento dos processos geológicos envolvidos na formação dos depósitos minerais representa um passo significativo para o planejamento de pesquisas na busca de novos recursos minerais.

Um dos principais problemas, se não o principal, encontrado na exploração das gemas da região da Serra do Espinhaço é a compreensão da posição e distribuição espacial dos corpos mineralizados. Além disso, apesar das gemas desta região serem aceitas no mercado internacional, pouco se conhece a respeito das suas propriedades gemológicas. O estudo a cerca do controle geológico das mineralizações de quartzo, das suas propriedades gemológicas e das técnicas de tratamentos as quais as gemas são submetidas para melhoramento de sua qualidade, requerem um estudo aprofundado.

Assim sendo, esta contribuição se torna relevante, no intuito de que irá colaborar com o entendimento do controle da mineralização em questão, acarretando em uma potencialização de recursos intelectuais destinados à obtenção de prósperas pesquisas minerais na região estudada.

\subsection{Metodologia de Trabalho}

A metodologia aplicada neste trabalho está dividida em seis etapas:

1. Levantamento e obtenção de dados teóricos e bibliográficos das ocorrências de quartzo e suas variedades já registradas na região do Espinhaço Setentrional, no Estado da Bahia.

2. Elaboração de uma síntese de dados, informações e conhecimentos sobre as gemas da região, dando destaque para as ocorrências de quartzo e suas variedades.

3. Visita de algumas ocorrências citadas acima para confirmação de dados e coleta de amostras, bem como mapeamento da região em questão, em busca de novas ocorrências para coleta do material a ser estudado. 
4. Realizar análises de espectroscopia em amostras coletadas para este fim, e análises físicas para avaliar a qualidade do quartzo produzido nas jazidas estudadas, bem como elucidar os fatores que contribuíram para as causas e mudanças das cores nas amostras coletadas.

5. Submeter as amostras coletadas a tratamentos térmicos e de irradiação gama, para obtenção de gemas coradas.

6. Integração dos dados e informações obtidas durante os trabalhos, culminando na confecção do modelo geológico e da dissertação. 


\section{QUARTZO NA BAHIA}

\subsection{Introdução}

A exploração do quartzo na Bahia tem sua história registrada nas memórias dos muitos mineradores da Chapada Diamantina, da Serra do Espinhaço e de outras regiões do Estado da Bahia, que a quase um século a incorporam às suas vidas $\mathrm{e}$ de seus familiares.

Essa história é narrada por inúmeros garimpeiros, como Agnaldo e Floriano (2007), e Fernando (2009), que descrevem em seus contos, os tempos em que os "gringos" aqui chegaram e começaram a abrir em meio a terrenos intocados da caatinga e do cerrado, estradas e campos de pouso; as primeiras viagens em comboios armados ou de avião, do mineral extraído; a chegada dos primeiros maquinários para ajudar na exploração do mineral; o primeiro polariscópio que aqui chegou, trazido por americanos, para separar os cristais em bons e ruins; os anos de bons e maus rendimentos; as "quebradeiras" prolongadas e explosões de dinamite; o encanto com o qual eles falam da compra do material de escória, que antes era jogado fora; dos preços de mercado interno que "vareia" de acordo com o do "estrangeiro" (informação verbal) ${ }^{1}$. E é desses relatos, causos, contos e histórias contadas por esses trabalhadores árduos e de mãos calejadas, que se tem a real história do quartzo na Bahia, a qual é documentada também no trabalho de Stoiber \& Butler (1945).

${ }^{1}$ Informações fornecidas por Agnaldo e Floriano, membros da Cooperativa Mista de Agropecuária e de Mineração - COOMAC, em Brejinho das Ametistas/BA, e por Fernando, na Mina do Coxo, em Jacobina/BA. 


\subsection{Aspectos Geológicos}

$\mathrm{Na}$ Bahia, o quartzo ocorre principalmente na região do Espinhaço Setentrional e da Chapada Diamantina, além dos municípios de Boninal, Brotas de Macaúbas, Jacobina, Ibitiara, Ipupiara, Oliveira dos Brejinhos, Anagé, Campo Formoso, Piatã e Sento Sé.

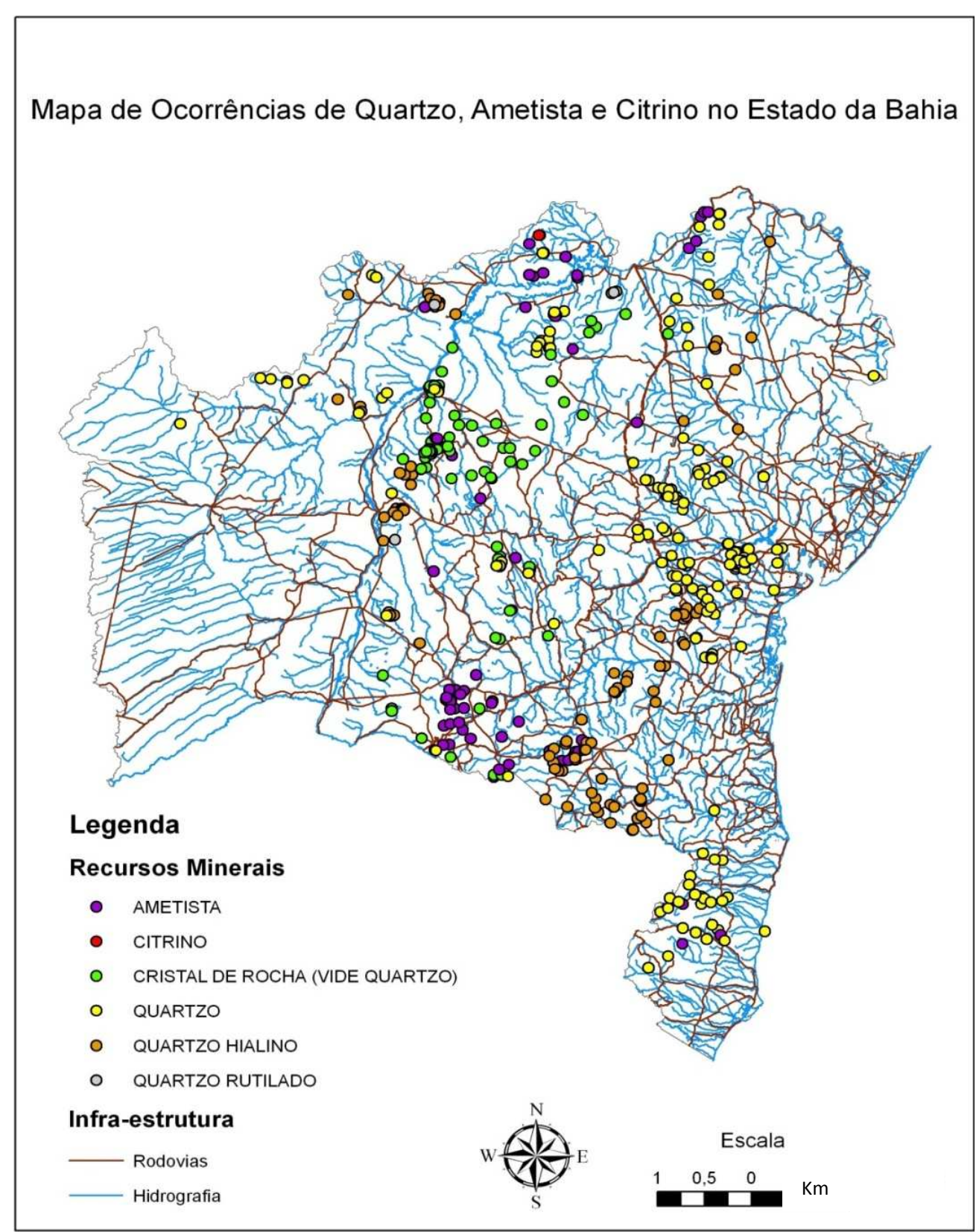

Figura 2.1: Mapa de Ocorrências de quartzo e suas variedades coloridas no Estado da Bahia. 


\subsubsection{Ambiente de Formação e Formas de Ocorrência}

O quartzo é gerado em zonas de baixa solubilidade de sílica, em temperaturas na faixa dos $300^{\circ} \mathrm{C}$. Ele pode ser encon trado em diversos ambientes geológicos, e sua aparência visual reflete as várias condições sob as quais ele foi formado. Diversos estudos relacionados a ambientes de formação do quartzo, permitiram a obtenção de um razoável acervo de dados sobre suas condições genéticas (Stoiber \& Butler, 1945; Dana, 1978; Yardley, 1983; Bodnar, et. al, 1985; White \& Hedenquist, 1990; Gratz, 1991; Evans, 1995; Arcoverde, 1997; Bons, 2001; Wangen \& Munz, 2004; Sumantri \& Setiawan, 2006; Pati et. al, 2007; entre outros).

O quartzo ocupa uma fração significativa da crosta terrestre (cerca de $12 \%$ ) e ocorre praticamente no mundo todo e em quase todos os tipos de rocha. É o mais comum dentre os minerais, ocorrendo em abundância tanto nas rochas ígneas (granito, riolito e pegmatito), metamórficas (gnaisses e xistos, formando os quartizitos) e sedimentares (acúmulo de grãos de quartzo formando arenito). É quase ausente nas rochas que constituem o assoalho oceânico (Dana,1978). Depositado como solução, o quartzo é o mineral mais comum dos veios e gangas; forma sílex depositado como nódulos nos fundos marinhos; soluções contendo sílica podem substituir camadas de calcários por um tipo criptocristalino de quartzo chamado chert, ou as camadas de chert podem ser formadas contemporâneas aos calcários (Diana, 2004). Ele é muito resistente ao intemperismo químico e físico, devido à ligação química e a sua dureza elevada entre os minerais formadores de rocha, e a ausência de clivagem. Nas rochas graníticas, o quartzo encontra-se associado principalmente ao feldspato e a mica (Branco, 1984). O quartzo também é encontrado em veios ou disseminado na rocha; em veios hidrotermais, veios pegmatíticos e graníticos; preenchendo fraturas em rochas metamórficas como quartzitos, granitos, filitos, gnaisses e xistos; preenchendo cavidades em rochas ígneas (geodos); em formas de filões ou em stockworks encaixado em rochas metamórficas; na forma de grãos fragmentários em leitos de rios, depósitos litorâneos (praia, terraços marinhos), nos cordões de dunas associados a depósitos litorâneos ou fluviais ou em depósitos secundários na forma de aluviões, eluviões e coluviões, além de ser um importante constituinte dos solos. Ocorrem também associados a depósitos de minerais metálicos, como cassiterita, wolframita, pirita, ouro, e outros (Schobbenhaus, et al, 1997). 


\subsubsection{Tipologia dos Depósitos de Quartzo na Bahia}

As principais fontes primárias de quartzo na Bahia relacionam-se a depósitos epigenéticos, nos quais as mineralizações ou depósitos minerais são formados posteriormente à formação da rocha encaixante.

As fontes secundárias são originadas pelo intemperismo e erosão de pegmatitos e veios hidrotermais ou, outras rochas portadoras de quartzo (principalmente rochas ácidas) e, posteriormente, concentradas e depositadas sob a forma de depósitos detríticos coluvionares ou aluvionares.

Dentre os modos de ocorrência estudados, destacam-se: a) veios hidrotermais; b) depósitos secundários.

\section{a) Veios Hidrotermais}

Os veios ou filões hidrotermais, como também são conhecidos, são o resultado de expressivas adições e/ou subtrações de componentes químicos, por meio da migração de fluidos aquosos de alta a baixa temperatura, desde curtas a longas distancias, e fornecem normalmente o quartzo hialino (cristal-de-rocha) e fragmentos ou lascas de quartzo. Devido aos veios serem quase que exclusivamente formados por minerais de quartzo, os mesmo também são conhecidos como "veios de quartzo". A grande massa desses veios é formada de quartzo leitoso, material de qualidade gemológica inferior ao quartzo hialino. Os veios hidrotermais de quartzo estão comumente encaixados em unidades essencialmente quartzíticas e/ou areníticas, secundariamente, pelíticas, datadas do paleoproterozóico ao neoproterozóico superior (Schobbenhaus, et. al, 1997).

De acordo com os mesmos autores, unidades contendo veios de quartzo encontram-se principalmente nos estados de Minas Gerais, Bahia, Goiás e Tocantins. Essas regiões representam os principais e tradicionais produtores de cristais de quartzo e lascas do Brasil. Trata-se de garimpos a céu aberto ou de lavra subterrânea, semi-mecanizada, que se desenvolve através de "grunas" (galerias subterrâneas precárias), onde a exploração é realizada de forma artesanal, muitos dos quais foram intensamente explorados durante a II Grande Guerra Mundial. Até 
hoje produzem de forma intermitente lascas e, em menor escala, cristais industriais e ornamentais.

O desmonte é feito com a ajuda de explosivos e ferramentas manuais, e a produção é rateada entre a cooperativa, e posteriormente repassada a agenciadores de indústrias de beneficiamento. O preço de mercado varia de acordo com a oferta e a procura, e normalmente são comercializados em lotes (Luz \& Braz, 2000, 2003).

As Inclusões mais comuns encontradas nos quartzos hidrotermais são cristais de goethita, hematita, ouro, rutilo, enxofre, turmalina, fluorita, manganês, entre outros (Bodnar \& Kuehn, 1985).

\section{b) Depósitos Secundários}

Junto à maioria dos depósitos primários, são encontrados depósitos detríticos coluvionares ou aluvionares, depósitos estes, que caracterizam-se por serem acumulações sedimentares formadas pela concentração mecânica de minerais de valor econômico, incluindo pedras preciosas, originados a partir da decomposição e erosão da rocha-fonte, principalmente através da ação do intemperismo e da água das chuvas, que lixiviam os depósitos fontes. Esses depósitos secundários já produziram e muitos produzem até os dias de hoje, grandes quantidades de cristais (Arcoverde, 1997). Na ultima década do século XX, os depósitos secundários passaram a receber mais atenção por parte dos pesquisadores (Karkunfel et. al, 1998).

\subsubsection{Ocorrências de Quartzo na Serra do Espinhaço}

Muitos estudos já foram realizados por diversos autores como Carvalho (1982); Dossin et. al. (1990); Chaves et. al, (1997 e 1999); Cruz (2000); FavachoSilva (2000); Chaves et. al, (2003); Cruz \& Alkimin (2004); com o intuito de melhor compreender as condições genéticas, os fatores envolvidos, a tipologia dos depósitos e os aspectos mineralógicos dos veios de quartzo da Serra do Espinhaço.

Durante o período neoproterozóico, na Serra do Espinhaço, foram gerados pela orogenia e metamorfismo do Ciclo Brasiliano, uma imensa quantidade de veios 
de quartzo hidrotermal (Uhlein et. al, 1986). Neste evento, condições de temperaturas próximas de $400^{\circ} \mathrm{C}$ e pressões de $4 \mathrm{Kbar}$ foram verificadas (Hoffmann, 1980). Os veios de quartzo encontram-se, na sua maioria, associados às rochas areníticas do Supergrupo Espinhaço, de idade mesoproterozóica, ou aos granitos e granitóides milonitizados do embasamento, de idade arqueana.

Um simples modelo para o desenvolvimento dos veios de quartzo na Serra do Espinhaço é o de Carvalho (1982), onde ele descreve que fluidos quentes, saturados em sílica, ascenderam por zonas de falhas e fraturas, e depositaram sua carga onde possível. Em conseqüência da diminuição da temperatura nos níveis crustais superiores, a solução torna-se superssaturada em sílica, a qual define 0 padrão dos veios de quartzo, depositando-o em zonas propícias. Com isso, veios de quartzo irregulares, de tamanhos variados, bastante leitosos e quase sem cristalinidade são normalmente gerados em zonas de baixa solubilidade de sílica, onde a temperatura não ultrapasse os 200 a $300^{\circ} \mathrm{C}$. J á em níveis crustais inferiores, onde a temperatura encontra-se na faixa de $400^{\circ} \mathrm{C}$ e a solubilidade da sílica é normalmente maior, os veios gerados são mais regulares, formando veios maiores, devido a maior facilidade de mobilização, e apresentando material de melhor qualidade.

Segundo Fyfe et. al. (1978), a quantidade de água necessária para a precipitação de um determinado volume de quartzo é da ordem de $10^{3}$ a $10^{4}$ vezes maior do que o volume do veio.

Considerando que os veios de quartzo da Serra do Espinhaço se formaram durante o Ciclo Brasiliano, e comparando essas condições de pressão e temperatura, com as representadas na curva de solubilidade do quartzo em água (Fyfe et. al, 1978), pode-se observar que a quantidade de quartzo que se precipita no intervalo de 150 a $300{ }^{\circ} \mathrm{C}$ é igual ou inferior a $1 \mathrm{~g} / \mathrm{Kg}$ de solução (figura 2.2). 


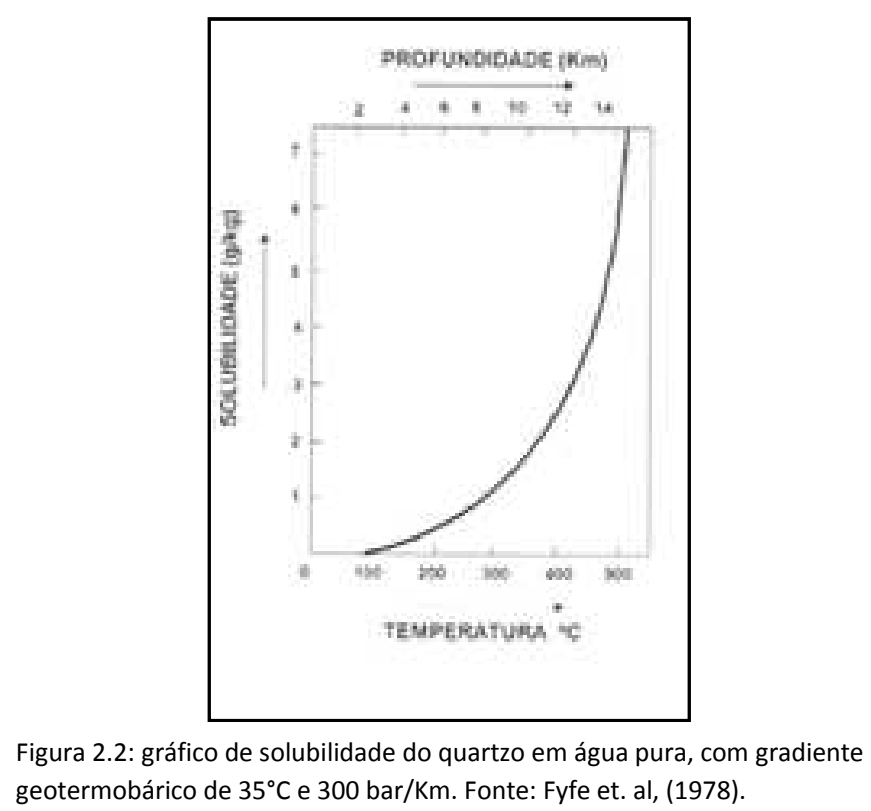

Acima desta faixa, o índice de solubilidade aumenta gradativamente em direção ao intervalo de 2 a $2,5 \mathrm{~g} / \mathrm{Kg}$ de solução, indicando que as condições de solubilidade do quartzo nessas condições de pressão e temperatura são suficientemente elevadas para explicarem o grande volume de quartzo presente nos veios, na região da Serra do Espinhaço.

Além da solubilidade da sílica e da temperatura, alguns outros fatores como a pressão do fluido, a pressão litostática, e a quantidade de água necessária para a formação dos veios, também interferem no processo de formação dos veios de quartzo (Favacho-Silva, 2000).

Os veios de quartzo, ao longo da Serra do Espinhaço, apresentam espessuras variáveis entre alguns milímetros até vários metros ou quilômetros. De acordo com Carvalho (1982), zoneamentos bem definidos podem ser localmente observados ao longo dos veios da Serra do Espinhaço. Este zoneamento é composto por quatro zonas:

- Zona 1- zona externa, constituída por quartzitos de granulação grossa (rocha encaixante), bastante fraturados, e parcialmente recristalizados.

- Zona 2 - zona de borda, apresenta-se em geral com cerca de $30 \mathrm{~cm}$ de espessura, contendo fragmentos brechóides de quartzitos cimentados por quartzo leitoso friável e fraturado. Esta zona nem sempre encontra-se presente. 
- Zona 3 - zona maciça, composta por quartzo branco leitoso, maciço, e pouco fraturado. Este quartzo é o principal material lavrado para a obtenção do Simetálico, por fundição.

- Zona 4 - zona cristalina ou zona do núcleo, a qual corresponde a porção central do veio, onde são encontrados quartzitos um tanto quanto menos leitosos e cristais de quartzo bem formados e transparentes, preenchendo cavidades irregulares, formando drusas. Os cristais bem formados geralmente apresentam qualidade gemológica.Tais veios são praticamente monominerálicos, podendo apresentar concentrações de hematita e/ou óxido de manganês. Esta zona, por muitas vezes, encontra-se ausente.

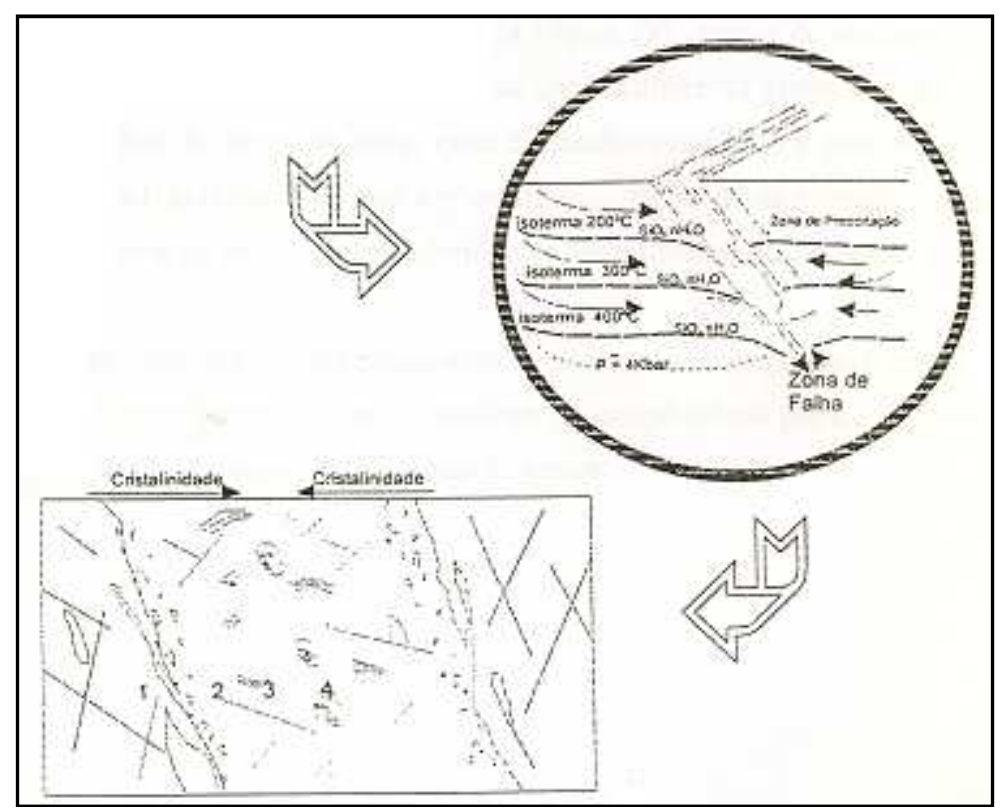

Figura 2.3: Diagrama esquemático das zonas de solubilidade do quartzo e sua consequente migração para as zonas mais permeáveis relativas à falhamentos; seguido do zoneamento dos veios de quartzo, onde 1 é a Zona de Borda; 2 a Zona brechóide, 3 a Zona maciça, 4 a Zona mais cristalina (central). Modificado de Favacho-Silva, (2000).

A mineralização de quartzo de Brejinho das Ametistas/BA mostra um notável controle estrutural (ver cap. 4), no qual os veios de quartzo ocorrem exclusivamente alojados nos quartzitos da Formação Salto.

Chaves (2003) sugere que a quantidade de água contida nas rochas areníticas altamente porosas, as quais originalmente constituíram a maior parte do Supergrupo Espinhaço, tenha sido suficiente para a geração dos veios de quartzo na região. 


\subsection{Aspectos Econômicos}

A produção de lascas de quartzo ocorria e ocorre de forma não sistematizada, como atividade garimpeira de forma rudimentar, realizada pela população local que trabalha em sistema de cooperativa.

De acordo com Almeida (1983), a produção de lascas de cristais de rocha é realizada por moradores das regiões já citadas, os quais saem pelas serras a procura de inúmeras ocorrências. Após encontradas, o quartzo é explorado com ferramentas manuais como enxadas, cavadores e ponteiras, e armazenado em sacos e caixas e transportado para as casas dos garimpeiros, onde com a ajuda de mulheres e crianças, realizam o quebramento e beneficiamento do quartzo em lascas, usando marretas e pequenos martelos.

O beneficiamento consiste, em uma primeira etapa, em eliminar do bloco cristalino as partes mais contaminadas por impurezas, inclusões e agregados cristalinos, e posteriormente separar a olho nu, em lotes distintos, de acordo com o comportamento óptico dos cristais e classificando-os em lascas de primeira linha; mistas; de segunda; e terceira linha, segundo padrões individuais dos garimpeiros (Almeida, 1983).

Segundo o mesmo autor, a segunda etapa do beneficiamento é realizada pela cooperativa, que compra dos garimpeiros suas produções individuais. Nesta etapa as lascas são lavadas, secadas e colocadas em bandejas de fundo branco, cobertas de água, onde os cristais são examinados sob a ação da luz natural ou fluorescente, visando descobrir inclusões macroscópicas ou defeitos na estrutura do cristal.

A comercialização das lascas de quartzo não é algo recente. A sistematização deste comércio ocorreu no fim da década de 50 , início dos anos 60 , durante a II Guerra Mundial, quando os Estados Unidos, a Alemanha e a Inglaterra careciam enormemente de cristais de quartzo devido as suas propriedades piezelétricas ${ }^{2}$, empregadas na fabricação de osciladores e filtros de freqüência, os quais eram utilizados nos instrumentos de comunicação (analógica) entre suas tropas militares. Com isso, ao final da década de 50, a indústria atingiu um ciclo muito intenso de oferta e demanda de quartzo. Antes do final da década de 60, o quartzo passou a fazer parte do estoque estratégico norte americano (Stoiber \& Butler, 1945). 
No final da década de 70 , com o surgimento da tecnologia de produção do quartzo cultivado em autoclave, a partir de lascas de quartzo como nutrientes, o qual permitiu a obtenção de um quartzo piezelétrico com as mesmas propriedades do quartzo natural, afetou profundamente a demanda de quartzo natural no mercado internacional (Braga, 1986).

Já no final da década de 80 , com o surgimento dos semi-condutores, a comunicação digital passou a ser utilizada, substituindo então, os circuitos analógicos pelos digitais, afetando ainda mais a indústria do quartzo piezelétrico ( Medina \& Reis, 1995).

A produção de lascas de quartzo na Bahia atingiu sua produção recorde em meados de 1983, chegando a mais de 10.000 toneladas. No ano de 1982, a Bahia já era responsável por $60 \%$ das exportações de lascas de quartzo, atingindo a marca de mais de $80 \%$ em 1983, superando os estados de Minas Gerais e Goiás, tradicionais exportadores de quartzo (Diniz Filho \& Arcoverde, 2000). O mineral era usado "in natura", eram selecionadas as regiões dos blocos cristalinos mais puros e livres de defeitos estruturais, os quais eram destinados a produção dos dispositivos elétricos (Arcoverde, 1988).

\footnotetext{
${ }^{2}$ A piezeletricidade é uma das mais importantes propriedades do quartzo, a qual foi observada pela primeira vez no século XVIII. Ela caracteriza-se pelo efeito da aplicação de uma tensão mecânica sobre o cristal, produzindo polarização elétrica, ou inversamente, pela aplicação de um campo elétrico causando a deformação do cristal.
} 
Dentre os maiores consumidores de lascas de quartzo produzidas na Bahia estavam a Alemanha, Bélgica, Polônia, Estados Unidos, Inglaterra, Japão, entre outros (Luz e Braz, 2000).

\subsection{Aspectos Tecnológicos}

Quando um homem primitivo atritava duas pedras para fazer fogo, arremessava sua lança de ponta para caçar e pescar, ou mulheres egípcias adornavam o corpo com colares e brincos de pedras coloridas, poderiam já estar fazendo uso da sílica, um dos materiais mais abundante na Terra.

As propriedades físicas do quartzo como a piroeletricidade, a dureza, o índice de refração entre outras, já eram muito utilizadas no passado, embora ainda não fossem devidamente compreendidas pelo homem primitivo (Luz e Braz, 2000).

De acordo com Luz e Braz (2000), com a chegada do século XX, e um acervo de conhecimentos básicos desenvolvidos ao longo das ultimas décadas do século anterior, desvendou-se a estrutura da matéria a nível atômico. Em meio a essas novas descobertas, o quartzo, o mais comum dos polímeros da sílica ganhou destaque especial nas pesquisas e estudos, sendo ele também, um dos maiores constituintes da crosta terrestre.

A determinação da sua estrutura cristalográfica (Bragg, 1914), as mudanças de fase com variações de temperatura, a descoberta da piezeletricidade (Pierre e Jacques Curie, 1981), a utilização do efeito piezelétrico para detecção de ondas sonoras na água (Langevin, 1914), o controle e padrão de freqüência em radiofonia (Cady, 1921), o elevado grau de elasticidade, fizeram e fazem do quartzo um dos minerais mais estudados em institutos de pesquisa e universidades no mundo todo, até os dias de hoje.

Tendo em vista as características positivas deste mineral, dominar e desenvolver a tecnologia do quartzo é indispensável a qualquer país que deseje um bom desenvolvimento econômico e tecnológico. 


\subsection{Aspectos Sociais}

As regiões produtoras de quartzo na Bahia são pouco desenvolvidas tanto economicamente como socialmente.

O minerador de quartzo exerce sistematicamente o mesmo ofício durante muito tempo seguido. Para alguns, esse tempo estende-se por toda a vida, sendo este o único trabalho realizado por ele. $\mathrm{O}$ garimpeiro é tido como aquele que busca materiais preciosos de modo pouco sistemático, esporádico e formalizado.

Inicialmente a atividade garimpeira era considerada ilegal, mas com o passar dos anos, passou a ser aceita por consenso, talvez em razão da insignificância dos achados e das raras possibilidades de se encontrar metais ou pedras preciosas nas antigas regiões mineiras, algumas transformadas em áreas de cascalhos revirados por mais de dois séculos de exploração contínua (Arcoverde,1988).

O trabalho sistematizado por longos períodos, para os mineradores, e a atividade esporádica e aleatória dos garimpeiros, constitui os pilares básicos da exploração do quartzo na Bahia.

A extração do quartzo e seu primeiro beneficiamento era um empreendimento tipicamente familiar no nordeste brasileiro. Nele participam todos os membros capazes da família, incluindo crianças e idosos. Infelizmente essas atividades não são perenes, devido à demanda da comercialização e os preços de mercado não sofrerem reajustes capazes de assegurar uma remuneração justa e estabilidades aos trabalhadores deste setor e sua família (Almeida, 1983).

A evolução da produção de lascas de quartzo na Bahia é caracterizada pela ausência de investimentos econômicos e tecnológicos neste setor, diferentemente do que acontece com outros metais e pedras preciosas exploradas na região, mesmo o quartzo apresentando grande importância comercial, potencialidade, e estando entre os minerais mais importantes na economia do Estado (Luz e Braz, 2000). 


\section{CONTEXTO GEOLÓGICO REGIONAL}

\subsection{Serra do Espinhaço}

A Serra do Espinhaço, ou Espinhaço, como também é conhecida, é compreendida como um conceito geográfico criado por Eschwege em 1822, com a finalidade de representar um sistema orográfico longo e estreito, o qual sua extensão vai desde o Quadrilátero Ferrífero, nas proximidades da cidade de Belo Horizonte, até os limites dos estados do Piauí e Pernambuco, cortando o Estado da Bahia em sua totalidade, com mais de $1000 \mathrm{Km}$ de extensão, e uma largura média na faixa de $20 \mathrm{Km}$.

Toda esta extensão encontra-se subdividida em quatro grandes domínios principais, sendo eles: Espinhaço Meridional, Espinhaço Central, Espinhaço Setentrional, e Chapada Diamantina (Figura 3.1) (Schobbenhaus, et. al, 1993).

$>$ Espinhaço Meridional

Corresponde ao domínio da Serra do Espinhaço que se encontra entre os paralelos $17^{\circ} 30^{\prime}$ e $20^{\circ} \mathrm{S}$ e $43^{\circ} \mathrm{e} 44^{\circ} \mathrm{E}$.

$>$ Espinhaço Central

Corresponde ao domínio da Serra do Espinhaço entre o paralelo 17\%30', até o fechamento do anticlinal Itacambira-Porteirinha.

$>$ Espinhaço Setentrional

Este domínio se estende pela região central da Bahia, aproximadamente desde o paralelo 14 `̊ , abrangendo toda a Província do Param irim, até o norte deste mesmo estado, onde se subdivide em duas longas e estreitas serras, sendo elas, a Serra do Boqueirão e a Serra do Estreito.

\section{Chapada Diamantina}

Este domínio da Serra do Espinhaço encontra-se totalmente inserido em território baiano, o qual seus limites estão compreendidos entre os paralelos $14^{\circ} \mathrm{e} 12^{\circ} 30^{\prime} \mathrm{S}$. 


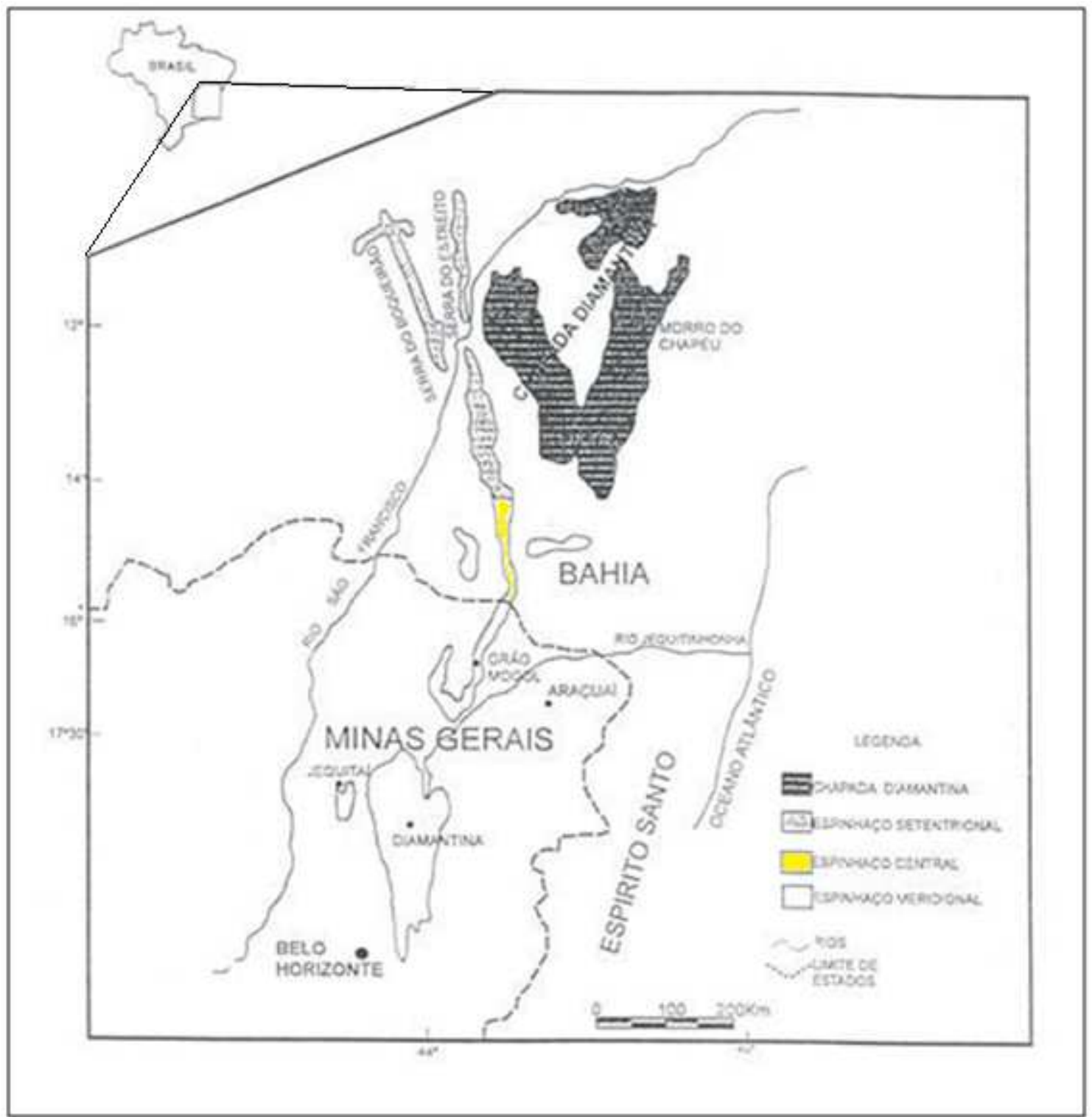

Figura 3.1: Subdivisões da Serra do espinhaço segundo quatro domínios principais: Espinhaço Meridional, Espinhaço Central, Espinhaço Setentrional, e Chapada Diamantina. Fonte: Modificado de Chaves, 1997.

Draper (1920) e Moraes Rego (1931) denominaram de Supergrupo Espinhaço, o conceito estratigráfico empregado para caracterizar o conjunto de unidades que ocorrem no contexto da Serra do Espinhaço.

De acordo com Schobbenhaus (1993), o termo "Espinhaço" na literatura geológica atual, pode ser compreendido por três diferentes conceitos, sendo eles: Geográfico; Estratigráfico; Geodinâmico.

A produção de quartzo na Bahia ocorre principalmente na região da Chapada Diamantina e da Serra do Espinhaço Setentrional, e secundariamente em outras 
regiões como Jacobina e Sento Sé, entre outras. Nessas regiões acima citadas, o quartzo é extraído e comercializado, na sua maioria, em forma de lascas.

\subsubsection{O Espinhaço Setentrional}

O domínio da Serra do Espinhaço correspondente ao Espinhaço Setentrional, como já mencionado acima, estende-se desde a região central da Bahia, abrangendo toda a Província do Paramirim, até o norte deste mesmo Estado, onde se subdivide em duas longas e estreitas serras, sendo elas, a Serra do Boqueirão e a Serra do Estreito. O Espinhaço Setentrional encontra-se totalmente inserido dentro do contexto do Corredor do Paramirim.

O Cráton do São Francisco (Figura 3.2) consiste em uma porção da crosta continental da plataforma Sul-Americana formada no neo-arqueano e estável desde o paleoproterozóico. Este cráton limita-se a nordeste pela Faixa Sergipana, a norte pela Faixa Riacho do Pontal, a noroeste pela Faixa Rio Preto, a oeste pela Faixa Brasília, a sudeste pela Faixa Araçuaí e a sul pela Faixa Alto do rio Grande (Almeida 1977).

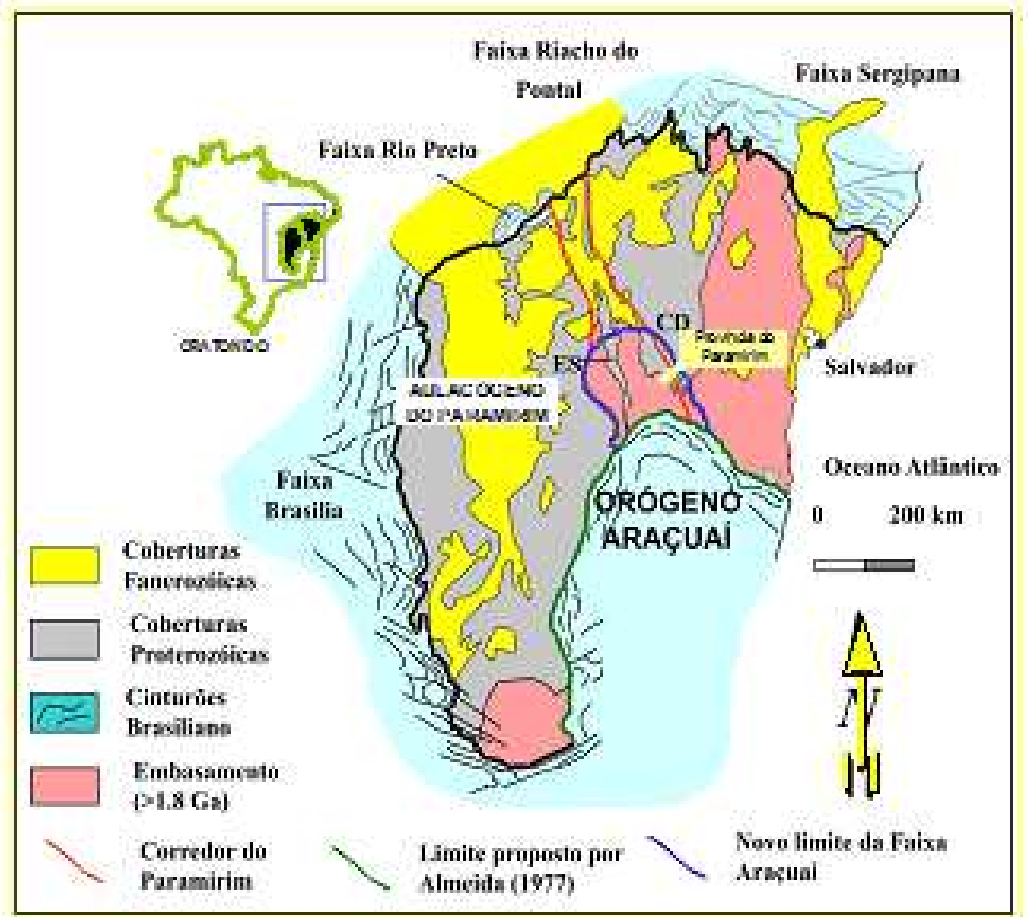

Figura 3. 2: Mapa tectônico simplificado da porção leste do Brasil, enfatizando o Cráton do São Francisco, o Aulacógeno do Paramirim e a Faixa Araçuaí. Fonte: Cruz (2004). 
Na porção baiana do Cráton do São Francisco, no seu embasamento, foram identificados por Barbosa \& Sabaté (2001), três blocos arqueanos denominados de Bloco Gavião, Bloco Serrinha e Bloco Jequié (Figura 3.3). Evidências geológicas sugerem a colisão desses três blocos arqueanos durante o paleoproterozóico, resultando na formação de uma importante cadeia de montanha, o Orógeno Itabuna-Salvador-Curaçá.

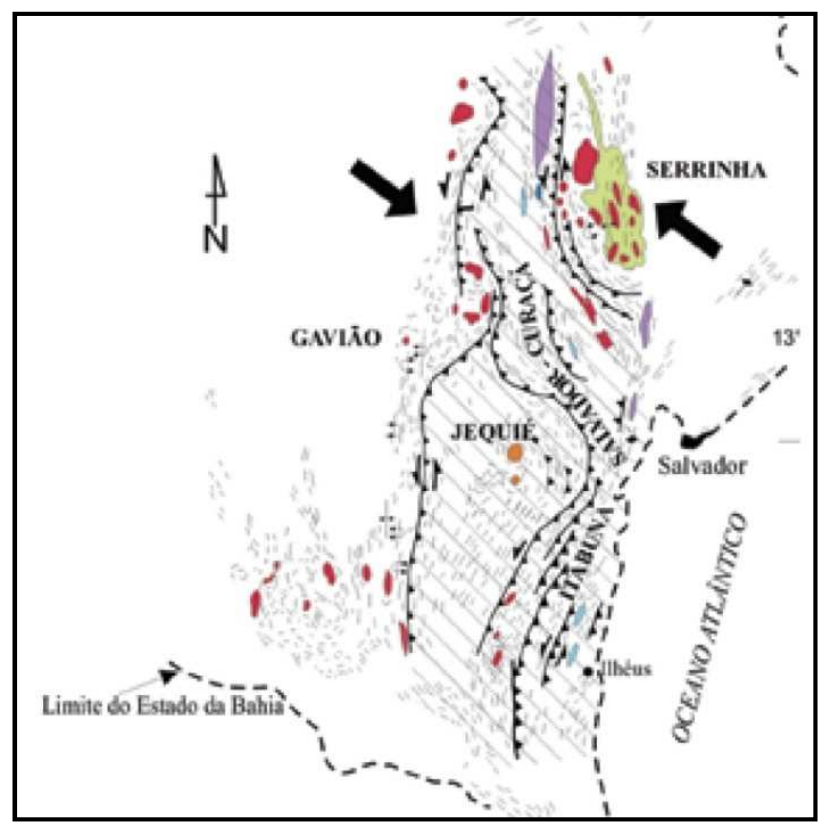

Figura 3. 3: Três blocos Arqueanos no embasamento do São Francisco. Estão assinaladas em cores, as rochas paleoproterozóicas e em branco, as rochas Arqueanas. Zonas de colisão e o sentido dos empurrões são também colocados. Fonte: (Barbosa \& Sabaté 2004).

No final do paleoproterozóico, sobre a crosta do Bloco Gavião, instalou-se o Aulacógeno do Paramirim, cuja distensão ocorreu através da instalação de bacias sucessoras que evoluíram até o neoproterozóico (Schobbenhaus 1996, DanderferFilho 2000).

No neoproterozóico, o Aulacógeno do Paramirim sofreu inversão parcial, estruturando o Corredor do Paramirim (Alkmin et. al, 1993). A porção sul desse corredor interagiu como front de deformação do Orógeno Araçuaí. Na zona de interação entre essas duas entidades tectônicas verifica-se uma grande curvatura, denominada de Saliência do Rio Pardo, que conecta o Cinturão de Dobramentos e Cavalgamentos da Serra do Espinhaço Meridional, com a zona de cisalhamento Potiraguá (Cruz 2004). 
A Província do Paramirim, segundo Misi et. al. (2006), encontra-se inteiramente inserida na porção invertida do Corredor do Paramirim, através de interação entre o Aulacógeno homônimo e o Orógeno Araçuaí (Cruz \& Alkmim 2006, Alkmim et. al. 2006), que compreende a porção ocidental da Chapada Diamantina e a região do Espinhaço Setentrional, onde ambos encontram-se situados a sul do paralelo $12^{\circ} 45^{\prime} \mathrm{S}$, com a presença do embasamento compreendido entre eles.

\subsubsection{Unidades Litoestratigráficas}

A seguir serão apresentadas as principais unidades litoestratigráficas que afloram regionalmente na área estudada (Figura 3.4).

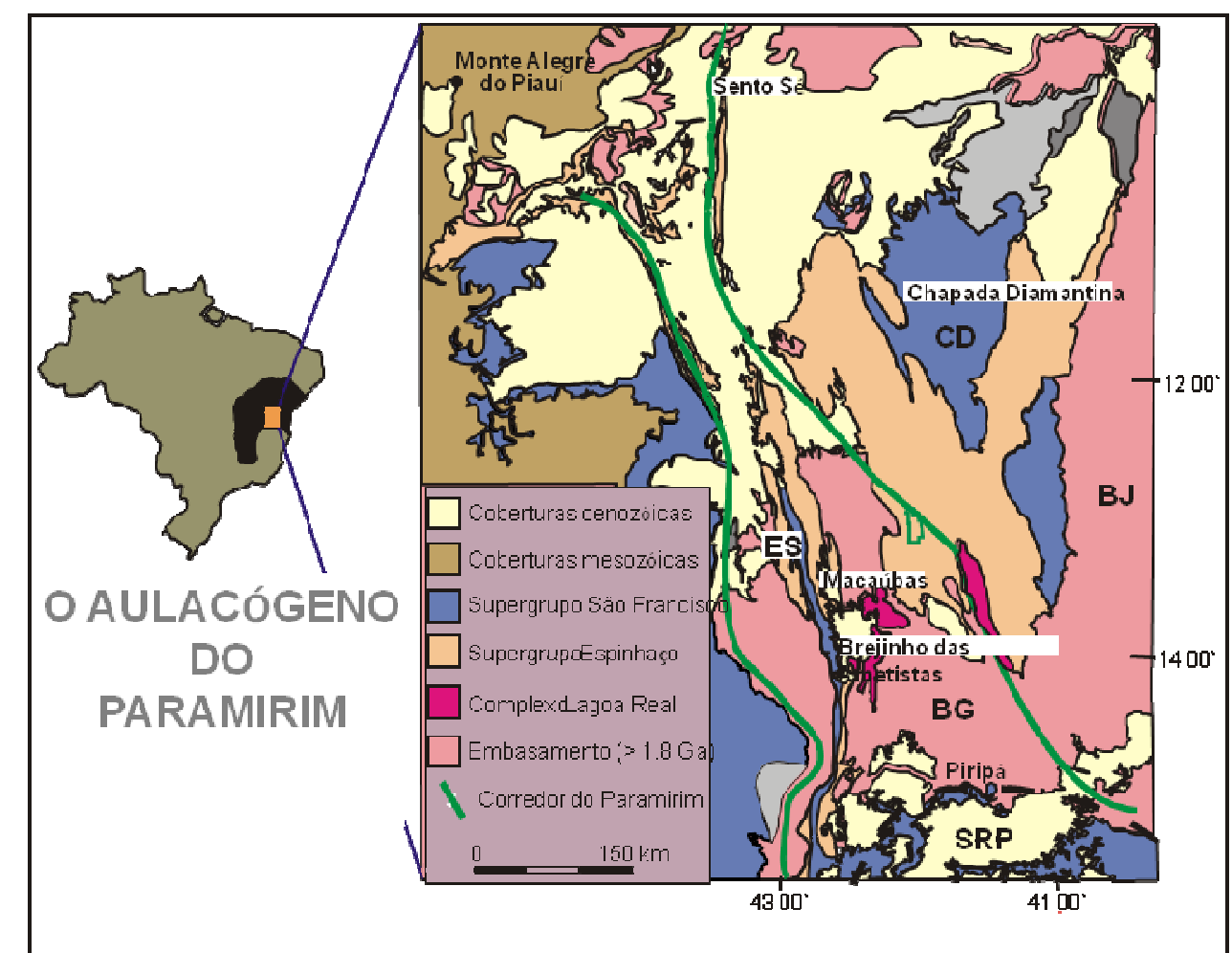

Figura 3.4: Mapa Geológico simplificado do Aulacógeno do Paramirim, enfatizando as principais unidades geológicas e estruturas tectônicas de idade brasiliana. BG- Bloco Gavião, BJ- Bloco Jequié, ES- Espinhaço Setentrional, CD- Chapada Diamantina, SRP- Saliência do Rio Pardo (Faixa Araçuaí). Mapa construído a partir de Schobbenhaus et al. (1981) e Barbosa \& Dominguez (1996). Fonte: Cruz (2004).

\section{a) Embasamento}

Este complexo é formado por ortognaisses e, subordinadamente, por paragnaisses (Moraes et. al. 1980) de idade arqueana a paleoproterozóica (Bastos Leal 1998). Os ortognaisses têm composição que varia de granítica a tonalítica, com 
textura milonítica e estruturas augen, estas marcadas por feldspatos. De acordo com aqueles autores, estes ortognaisses estão migmatizados em graus variáveis. Os paragnaisses associam-se com quartzitos, mármores, xistos, anfibolitos e rochas calcissilicáticas associadas com os terrenos vulcanossedimentares do Greenstone Belt de Ibitira-Ubiraçaba (Arcanjo et. al. 2000). De acordo com Rocha (1998), no embasamento predomina o metamorfismo de fácies anfibolito. O embasamento é denominado de Pré-Espinhaço, por Costa (1976).

\section{b) Complexo Lagoa Real}

O Complexo Lagoa Real está situado na parte centro-sul do Cráton do São Francisco, estando encaixado em migmatitos e gnaisses do Bloco Gavião (Arcanjo et. al. 2000, Cruz 2004). É constituído por um conjunto de rochas sianíticas, não deformadas, denominadas de Granito São Timóteo, e por gnaisses e albititos derivados da deformação daquelas rochas, assim como de anfibolitos, gabros, noritos, epidotitos e microclinitos (Cruz 2004). Este complexo hospeda um dos mais importantes distritos uraníferos do mundo, o qual encontra-se instalado em albititos. A mineralização de urânio está relacionada com processos de alteração metassomática envolvendo fluidos mineralizantes ricos em sódio e cálcio (Lobato 1985).

Através da datação U/Pb para o Granito São Timóteo, Turpin et. al. (1988) e Cordani et. al. (1992), obtiveram a idade de cristalização em torno de 1700Ma. Quanto à gnaissificação. Pimentel et. al. (1994) obteve idade em torno de 540Ma, que representa a idade do metamorfismo.

\section{c) Supergrupo Espinhaço}

Na porção sul do Corredor do Paramirim, o Supergrupo Espinhaço ocorre no Cinturão de Dobramentos e Cavalgamentos da Serra do Espinhaço Setentrional. Dominguez \& Rocha (1989) e Rocha (1991) subdividiram o Supergrupo Espinhaço em duas sequências deposicionais, denominadas, da base para o topo, de Grupo Borda Leste e Grupo Serra Geral (Figura 3.5). Essa é uma das subdivisões 
estratigráficas do Supergrupo Espinhaço mais utilizadas até os dias de hoje, as demais subdivisões serão citadas mais adiante.

No Grupo Borda Leste foram identificadas, da base para o topo, as Formações Mosquito, Salto, Sitio Novo e Santo Onofre. A Formação Mosquito é constituída por filitos granadíferos, grafitosos, de coloração cinza-escuro a claro ou esverdeado (Kaul 1970). De acordo com esse autor, camadas de quartzito ocorrem intercaladas aos xistos e não mostram qualquer estrutura sedimentar primária, com exceção de uma laminação plano-paralela. Quase sempre apresentam base plana e topo ondulado. No sentido do topo, esta formação apresenta intercalações decimétricas a métricas de formações ferromanganesíferas bandadas, de valor econômico. Esta formação tem sua maior área de expressão na porção meridional do Espinhaço baiano, estando ausente em sua porção setentrional. Esta formação foi interpretada como resultado da deposição em uma plataforma rasa sujeita a ação de tempestades que progressivamente adquirem a condição de uma plataforma "faminta", quando então se acumulam sedimentos químicos (formações ferromanganesíferas) (Dominguez \& Rocha 1989; Dominguez, 1992, 1993). 


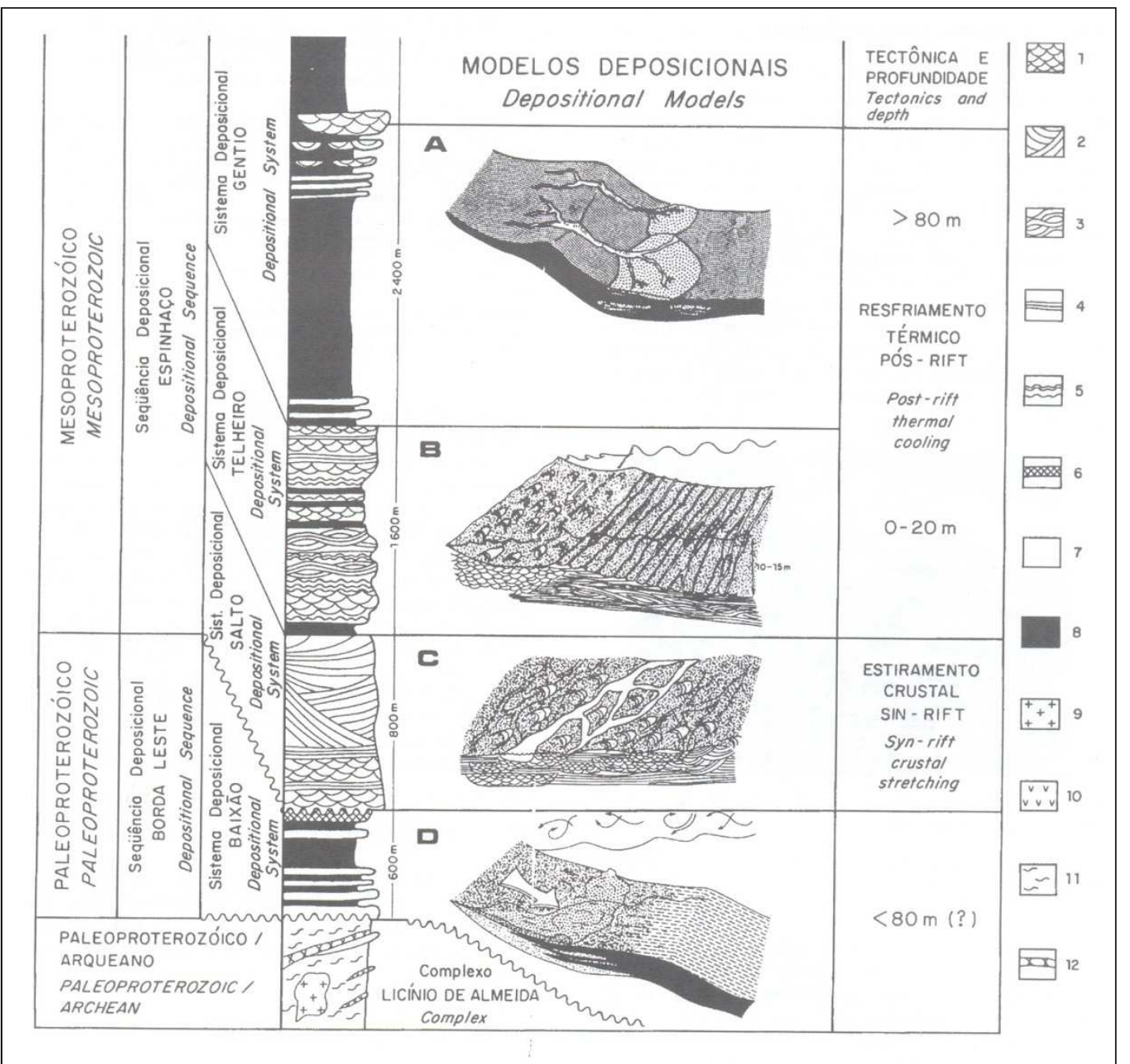

Figura 3.5: Coluna estratigrafica esquemática mostrando embasamento, principais sistemas deposicionais e ambientes tectônicos dos Grupos Borda Leste, Espinhaço Setentrional e Complexo Licínio de Almeida. Fonte: Rocha (1991).

O Grupo Serra Geral encontra-se em contato com o Grupo Borda Leste através de uma discordância erosiva (Figura 3.5). Foi dividido por Rocha (1991) em três formações, denominadas da base para o topo de Formação Salto, Formação Sítio Novo e Formação Santo Onofre (pertencente ao Supergrupo São Francisco). A Formação Salto é representada por conglomerados constituídos por seixos de quartzitos, provenientes do embasamento, de formações ferríferas e de metarenitos. Os metarenitos da Formação Salto possuem estratificações cruzadas de grande porte e estratos acanalados, denotando ambiente flúvio-eólico (Dominguez 1996).

A Formação Sítio Novo, por sua vez, é constituída por quartzitos sericíticos finos a grossos, com níveis subordinados de filitos avermelhados e filitos escuros 
grafitosos (Rocha 1991, Dominguez 1996). De acordo com esses autores, as principais estruturas sedimentares dessa unidade incluem estratificação cruzada de baixo ângulo e espessura decimétrica, laminação plano-paralela com marcas de ondulação simétricas, e localmente estratificação cruzada acanalada com paleocorrentes bidirecionais (espinha de peixe). Estes quartzitos são interpretados como resultado da deposição em uma plataforma marinha rasa, sob ação de ondas e correntes.

Schobbenhaus (1996), Barbosa \& Dominguez (1996), Danderfer Fo (2000), e Danderfer $\mathrm{F}^{\circ}$ \& Dardenne $(2001,2002)$ são alguns dos autores que formularam diferentes propostas de subdivisões estratigráficas e modelos deposicionais para 0 Supergrupo Espinhaço, como mostrado na tabela 3.1. Na tabela 3.2, podem ser observados os principais dados geocronológicos disponíveis na literatura, para as rochas do Supergrupo Espinhaço.

Tabela 3.1: Correlação geológica entre Espinhaço Setentrional e Chapada Diamantina, Segundo Danderfer fo (2000)

\begin{tabular}{|c|c|c|c|c|c|c|}
\hline \multicolumn{4}{|c|}{ ESPINHACO SETKNTRIONAL. } & \multicolumn{2}{|c|}{ CIIAPADA DIAMANTINA } & \multirow{4}{*}{$\begin{array}{l}\text { Idude } \\
\text { (Ga) }\end{array}$} \\
\hline \multicolumn{4}{|c|}{ Danderter $F^{2}(2000)$} & \multirow{2}{*}{\multicolumn{2}{|c|}{ Dasilerfer $\mathrm{F}^{2}$ (2000) }} & \\
\hline \multicolumn{2}{|c|}{ Aboesinatigrofía } & \multicolumn{2}{|c|}{ Lunestratigrafia } & & & \\
\hline Strame & Suhsisnewa & Gnupe & Fonimaçäe & Grupe & Formaçü? & \\
\hline \multirow{3}{*}{$\begin{array}{l}\text { Sanio } \\
\text { Onofre }\end{array}$} & Joง๋o Dhas & \multirow{3}{*}{$\begin{array}{l}\text { Sxmlis } \\
\text { Onofre }\end{array}$} & Jowin Dhas & \multirow{3}{*}{ Una } & Salitic & \multirow{3}{*}{$0,90-0,85$} \\
\hline & Bagutinio & & Bogecirio & & & \\
\hline & Canziba & & Cannibu & & Betederain & \\
\hline \multirow[t]{3}{*}{ Sitio Novin } & $\begin{array}{l}\text { Garapal } \\
\text { Sucurial }\end{array}$ & \multirow[t]{3}{*}{ Sitio Novo } & $\begin{array}{c}\text { Gasapa (cmoi } \\
\text { membou } \\
\text { Sucurial) }\end{array}$ & \multirow{3}{*}{$\begin{array}{c}\text { Chapsada } \\
\text { Diamancina }\end{array}$} & Morro do Chapću & \multirow[t]{3}{*}{$1,20-0,95$} \\
\hline & Viramundo & & Virimundo & & Caboclo & \\
\hline & Vuredas & & Verulas & & Tambalios & \\
\hline \multirow{3}{*}{ Sìo Marcas } & Pagendinha & \multirow{3}{*}{ Sho Marcos } & Fanendinhe & \multirow{3}{*}{ Panguacs } & Açurá & \multirow{3}{*}{15120} \\
\hline & Misquito & & Mosquito & & Guinć & \\
\hline & $\begin{array}{l}\text { Miacha do } \\
\text { Berile. }\end{array}$ & & $\begin{array}{l}\text { Fiacho do } \\
\text { Bento }\end{array}$ & & Tpupiara & \\
\hline Eom Reuro & 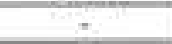 & & Bom Retirs & Mangrobeira & Mangabeif & $>1,51$ \\
\hline \multirow{3}{*}{ Pajcú } & Bambs & \multirow{3}{*}{ Pajou } & Bombs & \multirow{4}{*}{ Pajioti } & & \multirow{4}{*}{$1,7 \cdot 1,6$} \\
\hline & Ipucabu & & Jpesaba & & Lagaa de IXentro & \\
\hline & Rivcho Funda & & Riarlwo Fundn & & & \\
\hline Sapisanga & + & \multirow{3}{*}{ Bocuporầ } & Sypirangu & & Ouricuri do Ora & \\
\hline Ska Simàn & - & & S.in Simlo & $\begin{array}{l}\text { Río dos } \\
\text { Rcundios }\end{array}$ & Rio das Rancidios & \multirow[t]{2}{*}{$1,77-1,71$} \\
\hline Algesio & $=$ & & Agodalio & & & \\
\hline
\end{tabular}


Tabela 3.2: Principais dados geocronológicos das rochas do Supergrupo Espinhaço. Fonte: Martins (2008)

\begin{tabular}{|c|c|c|c|}
\hline Autar & Métıdio & Rocha / Lacal & Idade \\
\hline Jatdim do Să cetal (1976) & Rb/sr (Rochs total) & $\begin{array}{l}\text { Metavulcinicas/ Chapada } \\
\text { Diamavina }\end{array}$ & $\begin{array}{c}1.175 \pm 120 \mathrm{M} \times \text { (1dade } \\
\text { minima! }\end{array}$ \\
\hline Jandie de Sá si al (1976) & RtuSr (Rocha tatal) & $\begin{array}{l}\text { Metindeinicas' Espinhiço } \\
\text { Setentrional }\end{array}$ & 1.150 e.750Ma \\
\hline Britu-Neves et al (1980) & Rhisr (Rocha intal) & $\begin{array}{l}\text { Metavulclrsicas! Cluapada } \\
\text { Diamantina (Boiajara-ftuacu) }\end{array}$ & $1.000 \mathrm{Ma}$ \\
\hline Bubinsti et all (1994) & UTP $\left(Z_{\text {rfovies }}\right)$ & $\begin{array}{l}\text { Metavuleinicad Chapada } \\
\text { Diamantina }\end{array}$ & $1.748+1$ \\
\hline Schobbentuas et al (1991) & UPbiZiciestes) & $\begin{array}{l}\text { Melavuleingeds' Chapada } \\
\text { Diamamtina }\end{array}$ & $1.752 \mathrm{Ma}$ \\
\hline Jarilim de Sà et al. (1976) & fthst (Rocha total) & $\begin{array}{l}\text { Pelintos di Formaçà Caboclo } \\
\text { (Regiän de Morro do Cheociu) }\end{array}$ & $1.250 \pm 100 \mathrm{Ma}=910 \neq 80$ \\
\hline $\begin{array}{l}\text { Brito-Neves es al. }(1979) \text { e } \\
\text { Britu-Neves os al ( }(1960) \text {. }\end{array}$ & Fbisr (Rocha toxal) & 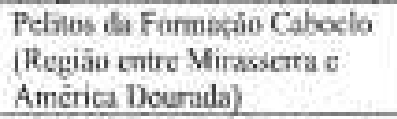 & Ente 1.300 e $1.2001 \mathrm{Ma}$ \\
\hline $\begin{array}{l}\text { Macedo \& Bonhormme } \\
\text { (1984) }\end{array}$ & Rbsir (thlicas) & $\begin{array}{l}\text { Pethins da Formaçio Cibocho } \\
\text { (Regian de Merra de (Chage) }\end{array}$ & $958 \pm 38 \mathrm{Ma}$ \\
\hline $\begin{array}{l}\text { Macede \& Henhorimse } \\
\text { (1954) }\end{array}$ & K/A, (Illies) & $\begin{array}{l}\text { Pelitoo de Furmacào Caboclo } \\
\text { (Regiâir de Monu do Chapón) }\end{array}$ & $706=16 \mathrm{M}=806 \pm 19$ \\
\hline Tshinki d al. (1993) & $\mathrm{PaP} / \mathrm{s}$ & 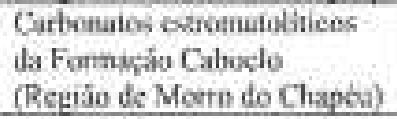 & $1.140 \pm 140 \mathrm{M} 2$ \\
\hline
\end{tabular}

\section{d) Rochas Básicas Intrusivas}

Consiste em um conjunto de rochas intrusivas, na maioria das vezes, gabróicas, dioríticas e diabásicas, as quais ocorrem cortando as unidades do Supergrupo Espinhaço, na região da Chapada Diamantina, na forma de diques e soleiras (Tanner-de-Oliveira \& Corrêa-Gomes, 1996; Danderfer-Filho, 2000). Segundo esses autores, são corpos com foliações de fluxo magmático, de filiação sub-alcalina, com idades 500 e $1200 \mathrm{Ma}$, obtidas através de K/Ar. Uma idade U/Pb em torno de 1.5Ga foi obtida por Guimarães et. al. (2005) para um dique de rocha básica em Lagoa do Dionísio, porção norte da Chapada Diamantina.

\section{e) Supergrupo São Francisco}

As unidades relacionadas ao Supergrupo São Francisco correspondem a depósitos mistos siliciclásticos e carbonáticos acumulados no neoproterozóico, em bacia de margem passiva (Dominguez 1996), ou flexural, gerada por sobrecarga de massa, conforme Delgado et. al. (2003). A sedimentação do Supergrupo São Francisco aconteceu, segundo Guimarães (2000), e Martins-Neto \& Alkmim (2001), entre 950 a 600Ma e sua coluna estratigráfica é constituída pelos Grupo Santo 
Onofre, na região do Espinhaço Setentrional, Grupo Bambuí a oeste do Espinhaço, e Grupo Una na Chapada Diamantina.

$\mathrm{Na}$ Serra do Espinhaço Setentrional, este Supergrupo encontra-se representado pelo Grupo Santo Onofre (Schobbenhaus 1996). A Formação Santo Onofre é constituída predominantemente por filitos sericíticos a silto-quartzosos geralmente laminados, e subordinadamente por quartzitos e conglomerados (Kaul 1970). Segundo este autor, o contato com a Formação Sítio Novo é gradacional, caracterizado pela alternância entre quartzitos médios a finos, típicos da unidade sotoposta, com estratificações cruzadas acanaladas e filitos cinza.

Os filitos apresentam-se geralmente cinzentos, claros ou escuros, a depender do teor de hematita, grafita e, mais raramente, óxidos de manganês (Rocha 1991). De acordo com esse autor, em alguns locais ocorrem mármores calcíticos sob a forma de pequenas lentes. Estes filitos são interpretados como resultado da deposição em ambiente relativamente profundo e calmo, onde durante a metade do tempo predominaram condições anóxicas (Danderfer Fo, 2000).

\subsubsection{Chapada Diamantina}

A Chapada Diamantina, denominada de Bacia de Lençóis por Indra \& Barbosa (1978) compreende dois domínios, Oriental e Ocidental, separados pelo Lineamento Barra do Mendes-João Correia (Sá et. al, 1976). No Domínio Ocidental, os dobramentos são apertados e o vulcanismo intenso. Já no Domínio Oriental, as dobras são suaves e o magmatismo é restrito principalmente a intrusões básicas.

De acordo com Silva (1994), a Chapada Diamantina é uma bacia do tipo riftesinéclise, com o estágio rifte representado por rochas vulcânicas da Formação Rio dos Remédios, e o estágio sinéclise pelos depósitos continentais e marinhos dos Grupos Paraguaçu e Chapada Diamantina.

Segundo Souza et. al. (2003), o empilhamento estratigráfico das coberturas sedimentares na região da Chapada Diamantina inclui os Grupos Paraguaçu (Formações Rio dos Remédios, Ouricuri do Ouro, Mangabeira, Lagoa de Dentro e 
Açuruá), e Chapada Diamantina (Formações Tombador, Caboclo e Morro do Chapéu).

As unidades estratigráficas da Chapada Diamantina (Supergrupo Espinhaço e Supergrupo São Francisco) foram afetadas por dobramentos anticlinais e sinclinais com eixos mergulhando suavemente para Norte. Os dobramentos foram responsáveis pelo aparecimento de clivagens e xistosidade nas estruturas rochosas da região. (Soledade 1985).

Dois importantes sistemas de falhamentos ocorrem na área, um de direção longitudinal, geralmente coincidente com a estrutura geral das rochas (NW-SE), com rejeitos direcionais como verticais. $\mathrm{O}$ outro sistema ocorre transversal ao primeiro, $\mathrm{e}$ apresenta rejeito direcional e pequena extensão.

Veios de quartzo leitoso aparecem com frequência preenchendo fraturas e zonas de falhamentos, além de serem comuns em rochas do Supergrupo Espinhaço, podendo também ocorrer em rochas da Formação Rio dos Remédios e do Complexo Metamórfico-Migmatítico.

No domínio da Chapada Diamantina, afloram as unidades do Supergrupo Espinhaço e do Supergrupo São Francisco, as quais serão descritas a seguir.

\subsubsection{Unidades Litoestratigráficas}

\section{a) Supergrupo Espinhaço}

O Supergrupo Espinhaço, no domínio da Chapada Diamantina, subdivide-se em Espinhaço Inferior, Espinhaço Meio e Espinhaço Superior (Costa, 1976).

O Espinhaço Inferior é representado pela Formação Rio dos Remédios, constituída por níveis ortoquartzíticos basais e rochas vulcânicas ácidas a intermediárias, representadas por riolitos, quartzo pórfiros, riodacitos e dacitos.

O Espinhaço Médio é representado, em ordem de idade cronológica decrescente, pelas: Formação Lagoa de Dentro, representada por quartzitos e conglomerados; Formação Mangabeira, composta por quartzitos e metaconglomerados; Formação Paraguaçú, formada por arenitos vermelhos 
metassiltitos e quartzitos; Formação Lavras, constituída por quartzitos e conglomerados diamantíferos.

O Espinhaço Superior é representado, também em ordem de idade cronológica decrescente, pelas: Formação Tombador, composta por quartzitos recristalizados e metarenitos intercalados; Formação Caboclo, constituída por metarenitos, metassiltitos e metarenitos; Formação Morro do Chapéu, formada por siltitos e arenitos. Segundo Schobbenhaus (1993) as duas primeiras formações representam sedimentos plataformais mesoproterozóicos, enquanto a Formação Morro do Chapéu é datada do neoproterozóico.

\section{b) Supergrupo São Francisco}

$\mathrm{Na}$ Chapada Diamantina, este Supergrupo encontra-se representado pelo Grupo Una (Schobbenhaus 1996), o qual é subdividido nas Formações Bebedouro e Salitre (Inda \& Barbosa, 1978).

A Formação Bebedouro é constituída por diamictitos com matriz grauváquica, arcosiana e quartzoarenítica, na qual flutuam seixos e matacões de composições variadas, quartzoarenitos, grauvacas, arcóseos e pelitos com ou sem clastos associados. Segundo Guimarães (1996), o ambiente deposicional é do tipo plataformal marinho, com influência glaciogênica. Macedo \& Bonhomme (1981, 1984), obtiveram em rochas pelíticas da Formação Bebedouro, idades Sr/Sr de 960 a $31 \mathrm{Ma}, \mathrm{K} / \mathrm{Ar}$ entre 901 e $21 \mathrm{Ma}$ e 876 a 20Ma, Rb/Sr e $\mathrm{Sr} / \mathrm{Sr}$ variando entre 932 a $30 \mathrm{Ma}$ e 911 a 27Ma. Tais idades foram interpretadas como marcadoras da fase diagenética.

A Formação Salitre é representada por um conjunto de litofácies carbonáticas que se alternam com pelitos (Inda \& Barbosa 1978; Misi 1993; Dominguez 1996; Guimarães 1996; Meneses Fo 1996). As estruturas sedimentares mais comumente encontradas são a laminação plano-paralela, estratificações cruzadas dos tipos hummocky e planar, e marcas de ondas. Segundo Leão \& Dominguez, (1992) e Leão et. al. (1992), seu ambiente de deposição é marinho raso, do tipo rampa carbonática, com constante agitação de ondas em planície de maré. Macedo \& Bonhomme (1984), e Toulkeridis et. al. (1999), realizaram datações $\mathrm{Rb} / \mathrm{Sr}$ dos 
carbonatos da Formação Salitre, os quais indicaram uma deposição entre 750 e $850 \mathrm{Ma}$. Já os resultados dos estudos isotópicos realizados por Misi \& Veizer (1996) indicam um intervalo de deposição para a Formação Salitre entre 700 e 560Ma.

Tabela 3.3: Propostas de colunas estratigráficas para o Supergrupo Espinhaço na Chapada Diamantina/BA. Fonte: Martins (2008)

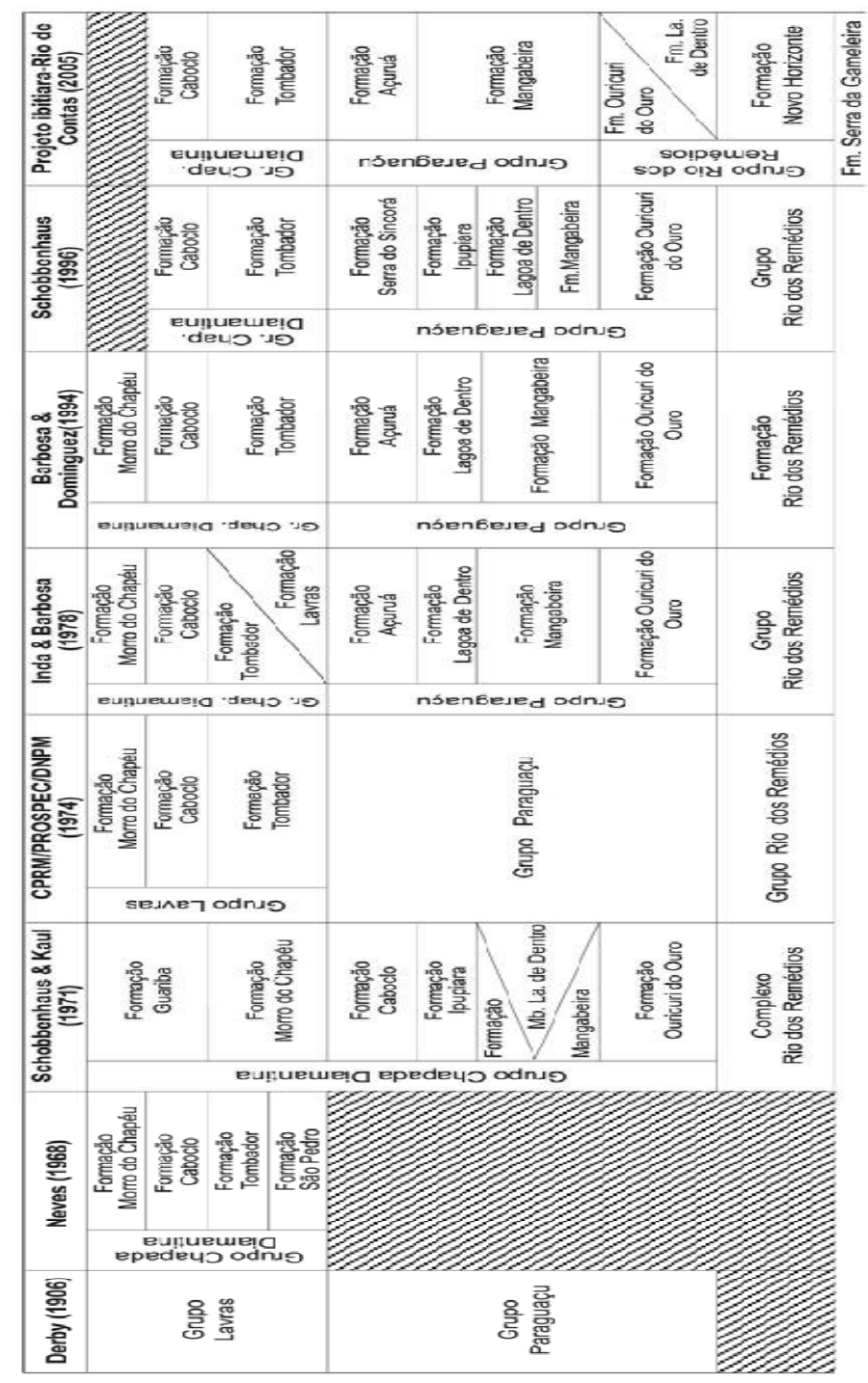

\subsubsection{Jacobina}

A geologia da região de Jacobina é representada por unidades que compreendem os períodos paleoproterozóico, representado por um pequeno corpo do Greenstone Belt de Mundo Novo (na base), englobando metabasaltos, metadacitos, rochas calcissilicáticas, anfibolitos, formações ferríferas, xistos e quartzitos, até rochas do período neoproterozóico, as quais compreendem o Grupo Jacobina (no topo). 
A estratigrafia básica do Grupo Jacobina foi definida por Leo et. al, (1964) com a seguinte constituição: Formação Bananeiras (xistos pelíticos com andaluzitacianita-granada-cordierita, e quartzitos); Formação Serra do Córrego (quartzito, ortoconglomerado e camadas de xistos); Formação Rio do Ouro (ortoquartzitos); e Formação Cruz das Almas (xistos pelíticos metamórficos com aluminossilicatos e quartzitos). As rochas ultramáficas encaixadas no Grupo Jacobina, subparalelamente à direção regional norte-sul, foram consideradas pelos autores, como diques ligeiramente discordantes, de composição primária peridotítica.

Griffon (1967) e Mascarenhas (1969) denominaram de Grupo Jacobina Inferior, a seqüência de xistos, gnaisses, calcissilicáticas, formações ferríferas, anfibolitos, ultramafitos e quartzitos que afloram ao longo da região, a leste da Serra de Jacobina, e subdividiram a Formação Cruz das Almas (Leo, et. al. 1964), da base para o topo, nas seguintes Formações: Cruz das Almas propriamente dita (xistos com níveis de quartzitos); Serra do Meio (quartzitos e conglomerados com níveis de cianita e andaluzita xistos); e Água Branca (xistos quartzosos, quartzitos, filitos e formações ferríferas bandadas, com mineralizações manganesíferas associadas).

Em 1971, Jordan admitiu que as rochas do Grupo Jacobina Inferior (Griffon, 1967 e Mascarenhas, 1969) constituíam o flanco leste do Sinclinório de Curaçá, do qual o Grupo Jacobina seria o flanco oeste.

De acordo com a definição de Couto et. al. (1978), o Grupo Jacobina corresponde a uma seqüência neoproterozóica, puramente sedimentar, de baixo grau metamórfico, onde predominam metassedimentos clásticos médios a grossos, distribuídos nas Formações Serra do Córrego (basal) e Rio do Ouro.

A Formação Serra do Córrego é composta por uma seqüência de metaconglomerados oligomícticos lenticulares, e de quartzitos de granulação grossa, o qual apresenta com freqüência, estratos cruzados e marcas de ondas. Os quartzitos são predominantemente brancos, verdes, ou avermelhados, de granulação grossa, recristalizados, e com presença de mica nos limites intersticiais. Nos conglomerados, predominam seixos de quartzo e quartzito, com tamanho, arredondamento e empacotamento variados, e matriz quartzítica. Sua deposição está relacionada a sistemas de leques aluviais e planícies aluviais, com 
paleocorrentes fluindo de leste para oeste. A Formação Serra do Córrego tem grande importância econômica, relacionada às lentes de metaconglomerados, onde se encontram jazimentos de ouro e/ou urânio a eles associados.

A Formação Rio do Ouro é constituída por ortoquartzitos brancos, cinzas e verdes, de granulação fina a média, bem cristalizados, e raramente friáveis, com estratificação cruzada na base, do tipo espinha-de-peixe, e marcas de ondas preservadas. A deposição desta formação está relacionada a ambiente marinho raso, dominado por marés. Veios de quartzo pouco espessos, alguns deles com concentrações auríferas ou outras mineralizações, podem aparecer cortando os quartzitos. 


\section{CONTEXTO GEOLOGICO LOCAL}

\subsection{Introdução}

Os principais depósitos de quartzo do Estado da Bahia, de qualidade gemológica encontram-se inseridos em três grandes contextos geológicos, sendo eles, a Serra do Espinhaço Setentrional, a Serra de Jacobina, e a Chapada Diamantina, nas quais predominam ocorrências de quartzo em veios hidrotermais. Algumas ocorrências de quartzo de natureza coluvionar e aluvionar também são exploradas nas regiões acima citadas.

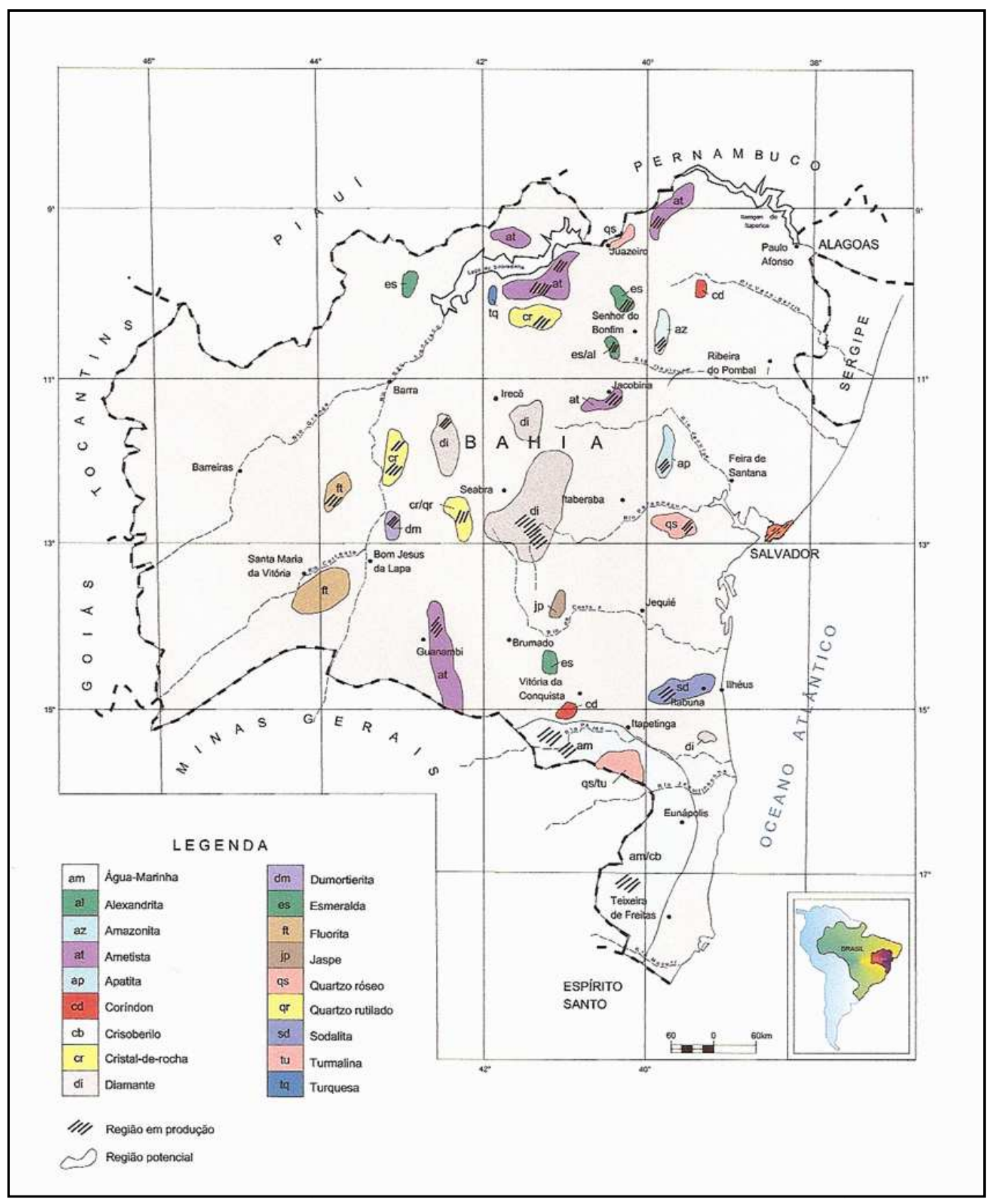

I. (2000). Modificado a xo, com os dados das 


\subsection{Tipologia dos depósitos de quartzo na Bahia}

Ocorrências de variedades levemente coloridas ou incolores do quartzo, que aceitem tratamentos por irradiação gama e tratamento térmico tem sido recentemente notificadas em depósitos secundários, fator este que levou os aluviões e coluviões de diversas regiões da Bahia, a constituírem um tipo de depósito intensamente procurado por geólogos, gemólogos e garimpeiros, devido ao valor comercial do seu material produzido.

Os depósitos de quartzo, observados no distrito gemológico em questão, apresentam duas tipologias principais, sendo elas, depósitos coluvionais e depósitos epigenéticos hidrotermais, os quais serão descritos abaixo.

\subsubsection{Depósitos Coluvionais}

Depósitos deste tipo caracterizam-se por serem acumulações sedimentares formadas pela concentração mecânica de minerais de valor econômico, incluindo pedras preciosas, originados a partir da decomposição e erosão da rocha-fonte, principalmente através da ação do intemperismo e da água das chuvas, que lixiviam os depósitos fontes, como é o caso dos garimpos da Brauninha e Vai Quem Pode, visitados em Brejinho das Ametistas/BA (Fotos 4.1; 4.2). Nesses depósitos, associado com a ametista foram observados seixos de quartzitos.

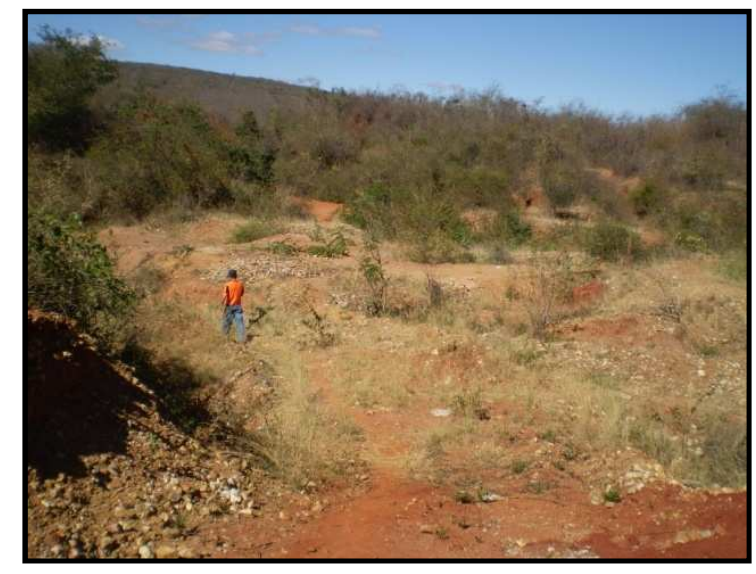

Foto 4.1: Vista geral do garimpo da Brauninha

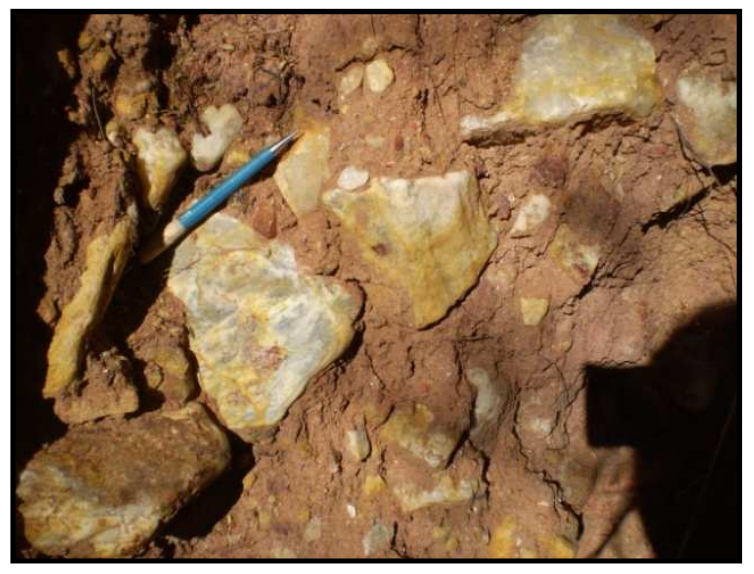

Foto 4.2: Detalhe do depósito mostrando os seixos de quartzitos no Garimpo Brauninha 


\subsubsection{Depósitos Epigenéticos}

São caracterizados por depósitos epigenéticos (hidrotermais) aquelas mineralizações ou depósitos minerais formados posteriormente à formação da rocha encaixante, como é o caso do garimpo da Mina do Paraguai (Fotos 4.3; 4.4), e garimpo da Mina da Bolívia, visitados em Brejinho das Ametistas/BA.

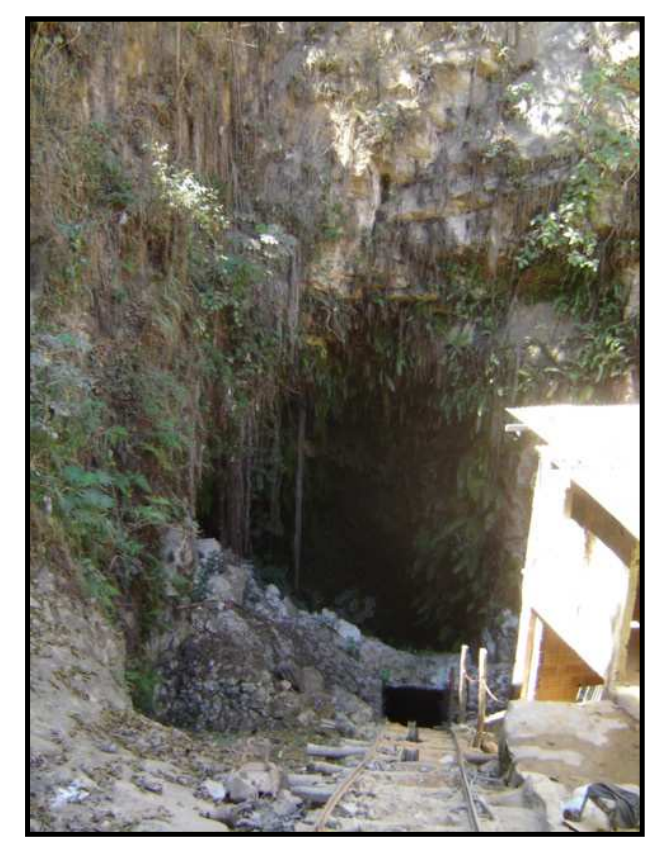

Foto 4.3: Boca da Mina do Paraguai

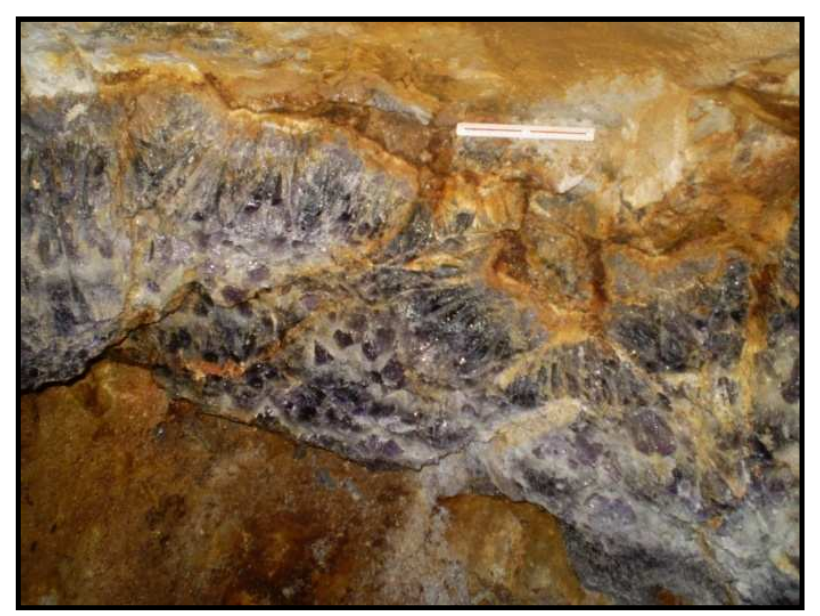

Foto: 4.4: Mineralizações de ametistas encaixadas em fraturas de tração nos quartzitos da Formação Salto, na Mina Paraguai

\subsection{O quartzo na Serra do Espinhaço Setentrional}

$\mathrm{Na}$ região em questão, os principais depósitos minerais são controlados por zonas de cisalhamento, as quais encontram-se subordinadas à evolução politectônica e são marcadas por sucessivos processos de reativações, acompanhadas de inversões tectônicas.

No Corredor do Paramirim, os distritos gemológicos apresentam elevado potencial, ocupando um quadro de destaque na economia mineral do Estado da Bahia. A atividade comercial envolvendo gemas é uma das mais importantes fontes de renda das comunidades da região. Os processos de tratamento e beneficiamento permitem a valorização das gemas e uma ampliação na margem de lucro da economia local. 
Dentre as gemas encontradas nesta região, de norte para sul, tem destaque para o quartzo hialino/rutilado de Oliveira dos Brejinhos, o cristal-de-rocha de Macaúbas, o cristal-de-rocha, citrino, ametrino e ametista da Serra do Salto (Licínio de Almeida) e de Brejinho das Ametistas (Caetité).

\subsubsection{Depósitos Estudados}

\subsubsection{Brejinho das Ametistas e Serra do Salto}

Segundo Werner Lieber (1994), provavelmente desde 1727 cristais de ametista baiana foram exportados ilegalmente para a Europa, mas de acordo com Santos (1995), as ocorrências de ametista de Brejinho das Ametistas foram legalmente "descobertas" no ano 1873, e as da Serra do Salto em 1891.

Os primeiros exploradores da ametista de Brejinho das Ametistas foram empresários alemães de Idar-Oberstein, que moraram e exploraram ametista em Brejinho das Ametistas por pouco tempo a vários anos. Empresários como Jakob Tasch (1880-1890), August Lambert (1883-1888), Irmãos Bohrer (1890), Karl Zorn (1890), Jakob Cullmann (1890), Nikolaus Verschuur (1895), Phil. Veeck (1895), Wilhelm Becker-Rische (1897), August Conrad (1897), Heinrich Henn (1897), Hugo Veeck (1905), Heinrich Albert Becker (1906-1945) e Kurt Walther Dreher e José Catarino da Silva, que receberam no dia 6 de maio 1954, pela primeira vez, oficialmente o requerimento (alvará) de pesquisa para a exploração de ametista e citrino no município de Brejinho das Ametistas, o qual situa-se a cerca de $22 \mathrm{~km}$ ao sul da cidade de Caetité (Falz 1939).

Segundo reportagem do Correio da Bahia (2007), os nomes para os garimpos como Califórnia, Paraguai e Bolívia foram criados pelos exploradores alemães, para confundir os compradores internacionais, sem revelar a origem real das ametistas. 


\section{a) Cristal-de-Rocha}

Esta variedade do quartzo, também conhecida como quartzo hialino, é um dos minerais gema mais abundantes, o que já permitiu ao Brasil ser o seu principal produtor mundial.

Nesta região, o cristal-de-rocha aparece, na maioria das vezes, associado às outras variedades do quartzo, tendo destaque para a ametista e/ou citrino e para o quartzo acinzentado, nas suas diversas tonalidades (enfumaçado, fumê e moriom), (Couto et. al, 2000).

As mineralizações ocorrem em stockworks ou filões de quartzo. De acordo com Cassedanne (1974), essas mineralizações são bastante freqüentes na região, as quais compreendem faixas silicificadas por circulação de fluidos hidrotermais ou meteóricos, formando crostas superficiais, de porosidade mediana, com nódulos de ágatas e calcedônias, ou lentes compactas com jaspe e calcedônia maciça.

\section{b) Citrino}

$\mathrm{Na}$ Bahia, sob o nome de citrino são comercializadas tanto a variedade natural (in natura) amarelo alaranjado do quartzo (não muito freqüente), encontrados associados às ametistas, quanto o produto resultante da queima (tratamento térmico) da ametista ou de certos cristais acinzentados (enfumaçados), esverdeados, e as vezes arroxeados, os famosos cristais de ametrino, os quais também são conhecidos na região como "Lambreo" (Couto et al. 2000).

\section{c) Ametistas}

A exploração da ametista corresponde a 14,84\% dos jazimentos de gemas do estado da Bahia (Figura 4.2) (Couto et. al, 2000). O distrito de Brejinho das Ametistas se consolidou como um importante produtor no cenário estadual, e sua ametista corresponde a 54,83\% das gemas produzidas na região (Misi et. al. 2006), mas infelizmente, por falta de investimentos, atualmente a produção encontra-se parada. De acordo com este autor, esse distrito situa-se na porção sul da Província Metalogenética do Paramirim, na feição tectônica denominada de Cinturão de 
Dobramentos e Cavalgamentos da Serra do Espinhaço Setentrional. Este cinturão compõe o Corredor do Paramirim, que corresponde à porção tectonicamente invertida do Aulacógeno homônimo, durante o neoproterozóico.

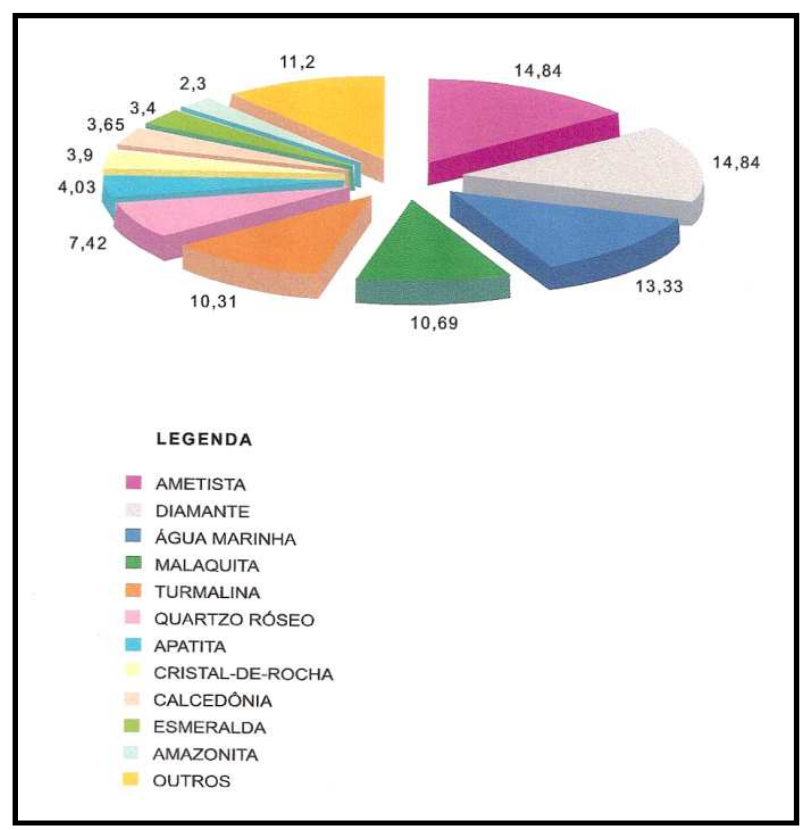

Figura 4.2: Distribuição Quantitativa dos jazimentos da Bahia (em \%). Fonte Couto et. al, 2000.

A ametista é uma gema muito popular e abundante, mas nem todas apresentam um potencial gemológico. Na Bahia ocorrem grande parte das principais mineralizações brasileiras de ametista (Couto et. al, 2000). Neste sentido, de acordo com este autor, destacam-se as ocorrências da Serra do Salto (Fazenda Serra do Salto), localizada no município de Licínio de Almeida, e as ocorrências do distrito de Brejinho das Ametistas, pertencente ao município de Caetité.

As concentrações de ametista, nesta região, ocorrem de duas formas principais, sendo elas, a forma primária, como drusas em veios de quartzo que cortam litologias da região, normalmente em zonas de falhas e fraturas (filões ou em stockworks); e formas secundárias, comumente associadas às coberturas detritolateríticas, onde este mineral ocorre na forma de rolado, associado aos níveis de cascalhos, intercalados nestes depósitos. Os depósitos in-situ, na maioria, ocorrem nas rochas da Formação Salto (Supergrupo Espinhaço) e estão associados com as ocorrências de ferro e manganês. Os depósitos aluvionares ocorrem recobrindo as rochas xistosas da Formação Mosquito (Figura 4.3). 


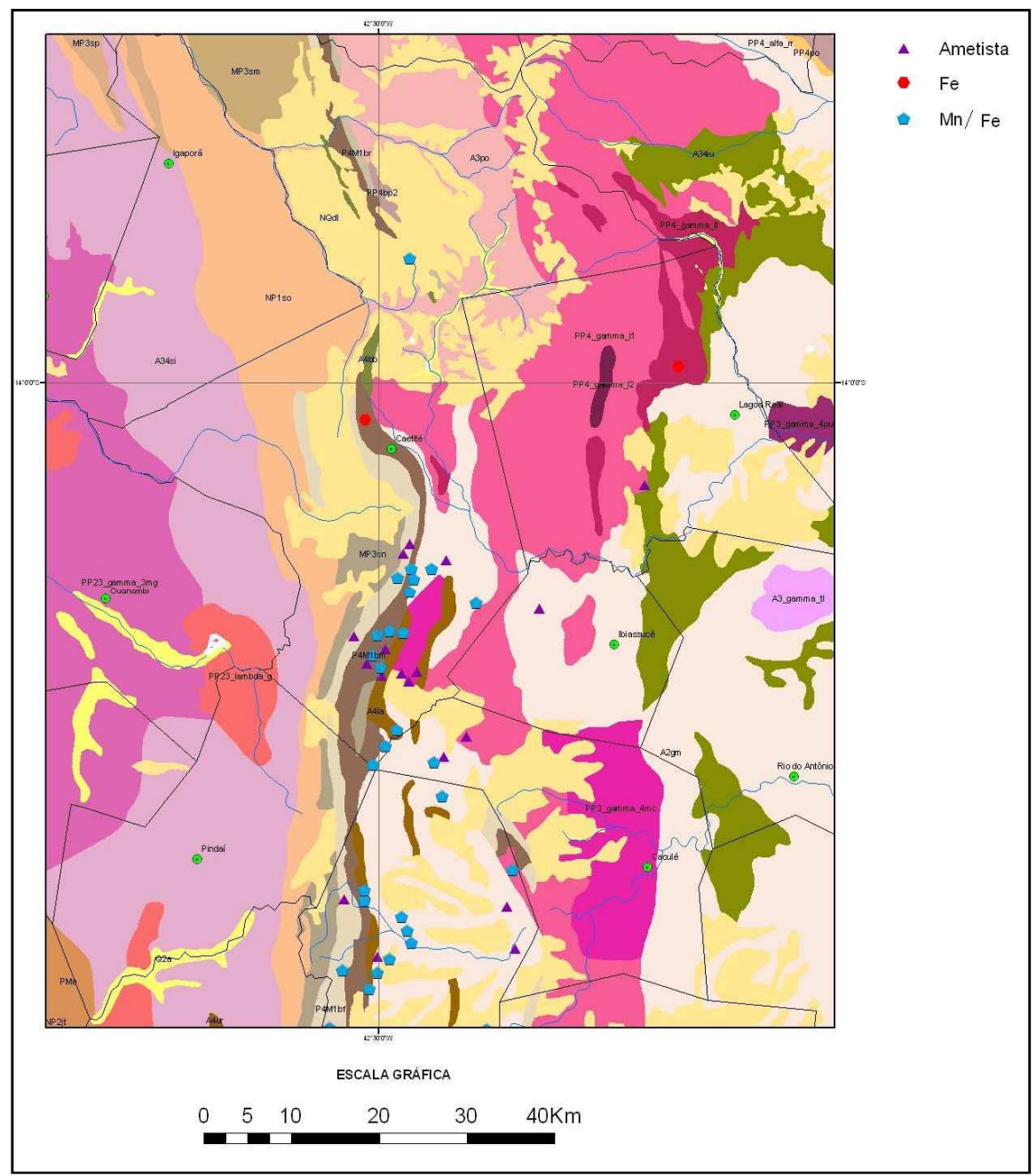

Figura 4.3: Mapa Geológico simplificado mostrando as ocorrências de Ametista, Ferro e Manganês da região.

De um modo geral, as mineralizações in situ da Fazenda Serra do Salto e de Brejinho das Ametistas, posicionam-se na Serra do Espinhaço Setentrional, e estão encaixadas em fraturas alojadas nos quartzitos da Formação Salto (Grupo Serra Geral, Supergrupo Espinhaço).

Para Misi et. al. (2006), os domínios mineralizados correspondem a faixas tectonizadas, na qual grandes blocos de rochas bascularam uns sobre os outros. Nas fraturas, a ametista aparece recobrindo toda a superfície, formando um mosaico de larga beleza. Em ambos os jazimentos citados, a ametista ocorre como drusas de forma radial, geodos, preenchendo veios, fraturas e cavidades, ou em forma de cristais disseminados no quartzito, apresentando cristais com faces desenvolvidas, inseridos em material esbranquiçado de granulação muito fina (Couto et. al, 2000). 
Nas adjacências dos jazimentos de ametista in situ, são encontrados depósitos secundários desta gema nas formas de aluviões, eluviões e coluviões, os quais são, na sua maioria, de pequeno porte, com exceção para o distrito de Brejinho das Ametistas, onde tem sido explorado um vasto lençol aluvionar, que bordeja a leste, a Serra do Espinhaço, localmente conhecida como "Serra das Ametistas", tendo destaque para os garimpos Vai-Quem-Pode, Brauninha, Rapa, Coiraná, Califôrnia, entre outros situados ao redor do município (Cassedanne, 1974). No referido lençol aluvionar, muitas lentes de conglomerados se apresentam constituídos por seixos e lascas de quartzo leitoso, e de alguns cristais de ametista, cimentados por material argilo-arenoso (Misi et. al, 2006). De acordo com o mesmo autor, esses conglomerados se originaram através do intemperismo físico (erosão) sofrido pelos veios e lentes de ametista e quartzo, que afloram na região da Serra do Espinhaço.

As gemas do garimpo Paraguai (Foto 4.5) apresentam uma coloração bastante escura, enquanto que as mineralizações da Serra do Salto (Foto 4.6) apresentam cristais um pouco menos corados. No garimpo da Bolívia, por sua vez, os cristais são muito claros. O teor gemológico dessa última é muito baixo, e a exploração é realizada a céu aberto ou em galerias tortuosas. A grande maioria dos exemplares explorados nesse garimpo é quase incolor.

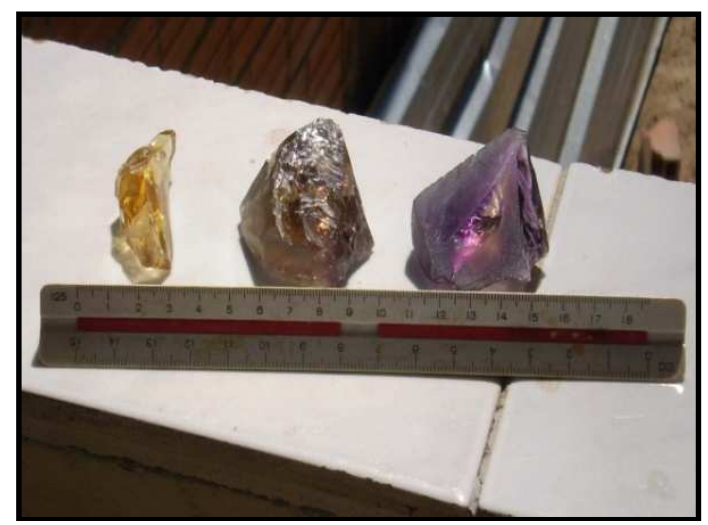

Foto 4.5: Amostras de ametista, quartzo fumê e citrino (ametista queimada) da Mina do Paraguai, Brejinho das Ametistas/BA.

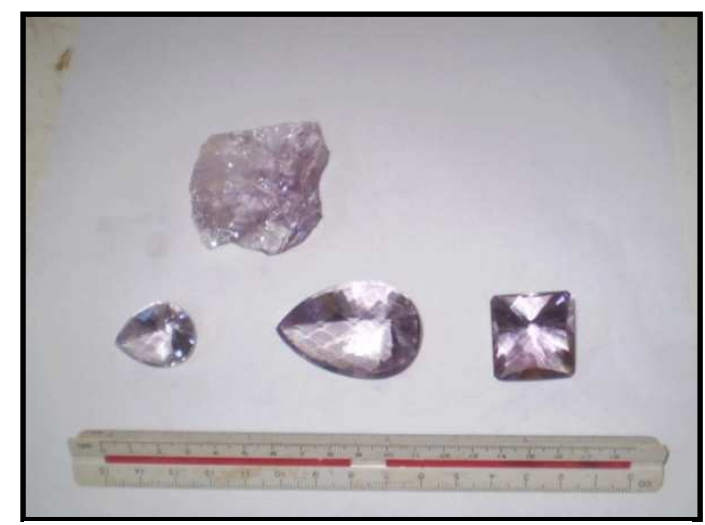

Foto 4.6: Amostras de ametista da Mina da Bolívia, Brejinho das Ametistas/BA.

Na maioria dos garimpos da região, a ametista é extraída de forma artesanal, e em apenas alguns, é realizada através de lavra subterrânea, semi-mecanizada, que se desenvolve através de "grunas" (galerias subterrâneas precárias), nas quais 
os garimpeiros fazem o desmonte com a utilização de explosivos e ferramentas manuais (fotos 4.7 e 4.8). As inclusões de hematita, mais comumente encontradas na ametista, são eliminadas em um processo de seleção manual, realizado no próprio garimpo. (Fotos 4.9).

Alguns garimpos foram abandonados, por conta da baixa produtividade, qualidade do material e a conseqüente queda de preço. Atualmente, dentre os garimpos visitados, encontra-se em atividade apenas o garimpo da Serra do Salto, instalado na Serra do Salto, em Licínio de Almeida.

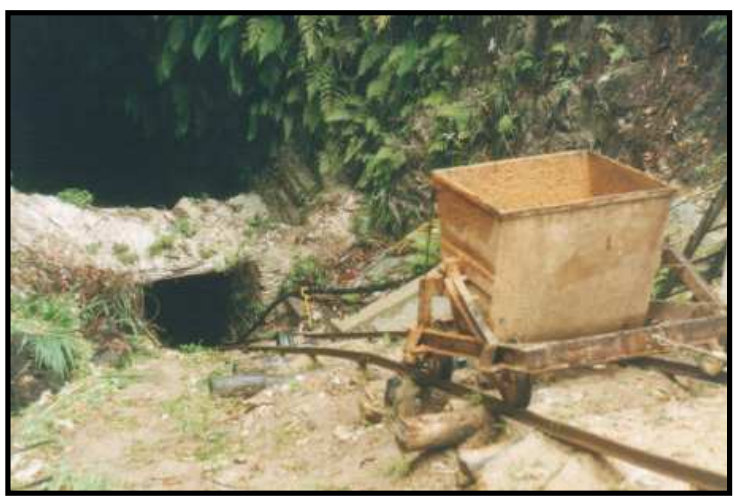

Foto 4.7: Vista da entrada da Mina Paraguai, Caetité/BA

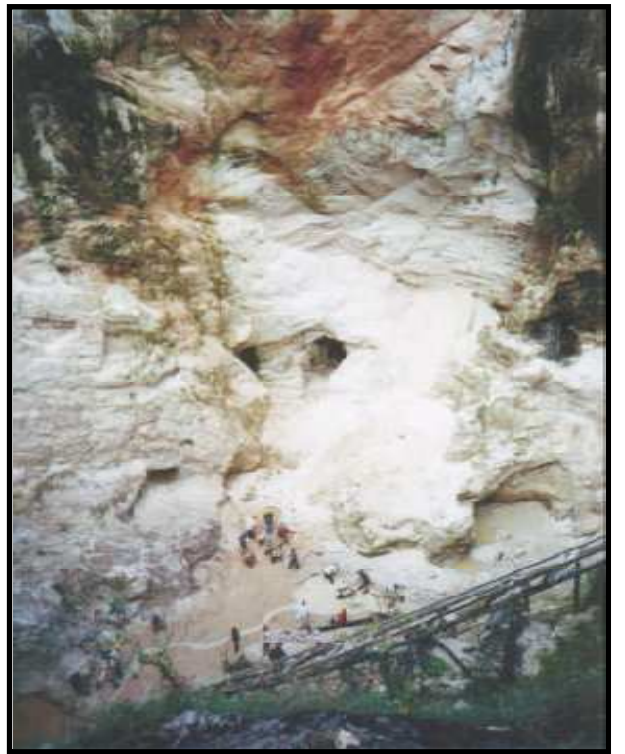

Foto 4.8: Vista parcial das "grunas" do garimpo da Serra do Salto, Licínio de Almeida-BA

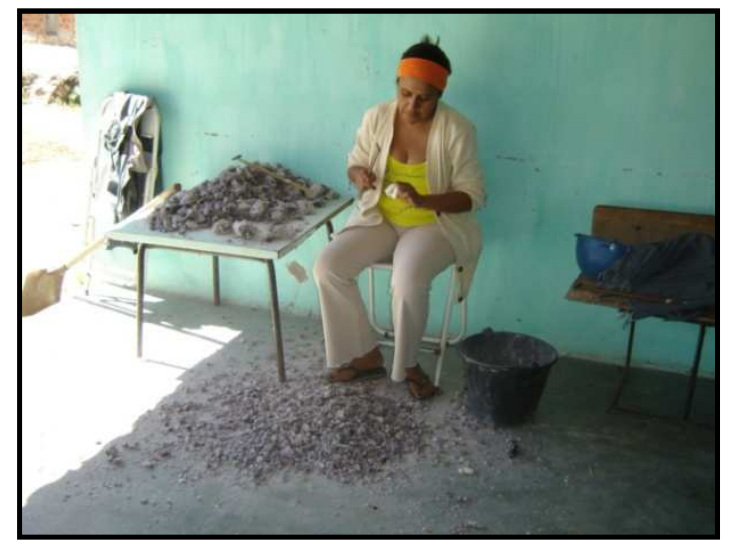

Foto 4.9: seleção manual para eliminação da impregnação de hematita na ametista 
Toda a produção é rateada entre a cooperativa e os garimpeiros que trabalham na exploração, sendo esta posteriormente repassada a terceiros, que geralmente são agenciadores de indústrias de beneficiamento de dentro e fora do Estado.

Apesar da importância da mineralização, existe uma carência de estudos científicos que abordem questões relacionadas com a evolução dos depósitos de ametista da região.

\subsection{Caracterização Geológica e Estrutural da Mineralização}

$\mathrm{Na}$ região de Brejinho das Ametistas os depósitos de quartzo estão hospedados na Formação Salto (Supergrupo Espinhaço). A estruturação é marcada por um conjunto de zonas de cisalhamento compressionais que justapõe as unidades do embasamento sobre os xistos da Formação Mosquito e estes sobre a Formação Salto (Figura 4.4).

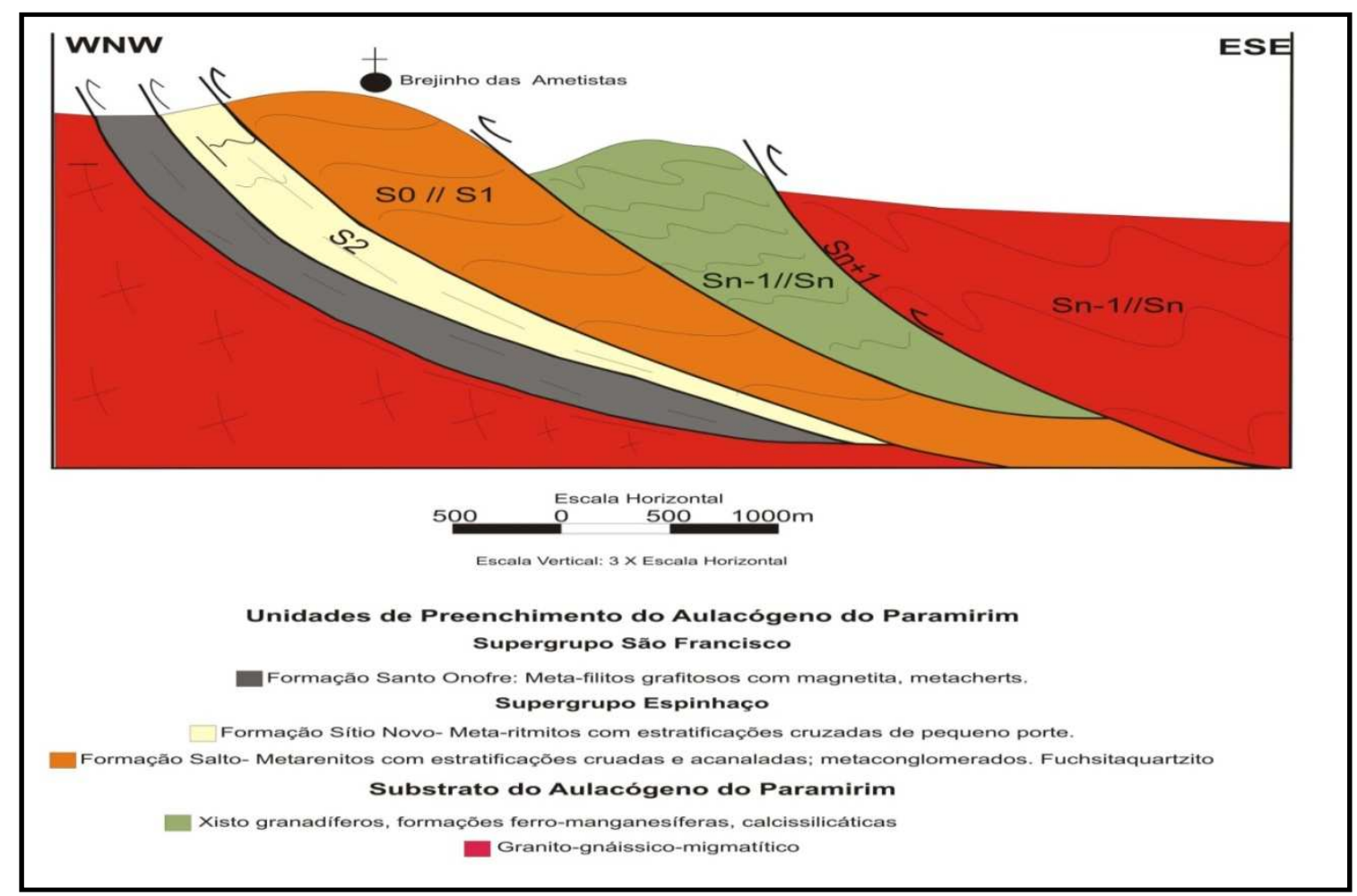

Figura 4.4: Perfil Geológico Esquemático da região de Brejinho das Ametistas construído a partir dos dados de campo 
Os trabalhos de análise estrutural foram realizados no garimpo da Mina do Paraguai, localizado em Brejinho das Ametistas (Caetité-BA).

A mineralização de ametista no garimpo em questão possui coloração violeta intenso (Foto 4.10), hábito prismático e encontra-se preferencialmente em arranjo radial (Foto 4.11). As faixas mineralizadas estão encaixadas em fraturas de tração, com geometria fusiforme e distribuição errática, alojadas em rochas metareníticas/quartzíticas da Formação Salto (Supergrupo Espinhaço). Tais fraturas posicionam-se, preferencialmente em baixo ângulo com a foliação S0//S1 (Foto 4.12). Um conjunto menos expressivo de fraturas se posicionam em alto ângulo com o S0 e ortogonalmente distribuída com relação às guirlandas do S0 (Figuras 4.5; 4.6) e das fraturas subhorizontais. Não foram observadas relações de truncamento entre elas.

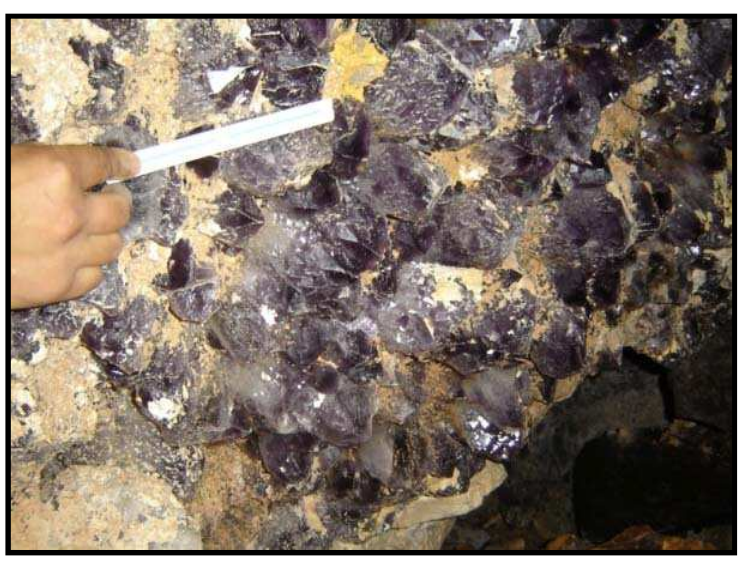

Foto 4.10: Detalhe dos cristais de Ametista de coloração violeta intenso na mina Paraguai, Brejinho das Ametistas/BA.

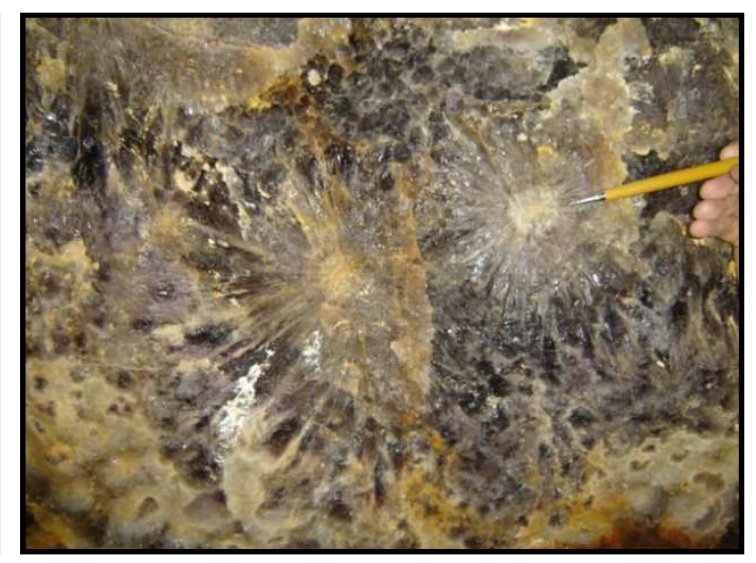

Foto 4.11: Arranjo Radial da lineação de crescimento dos cristais de ametista, da mesma localidade.

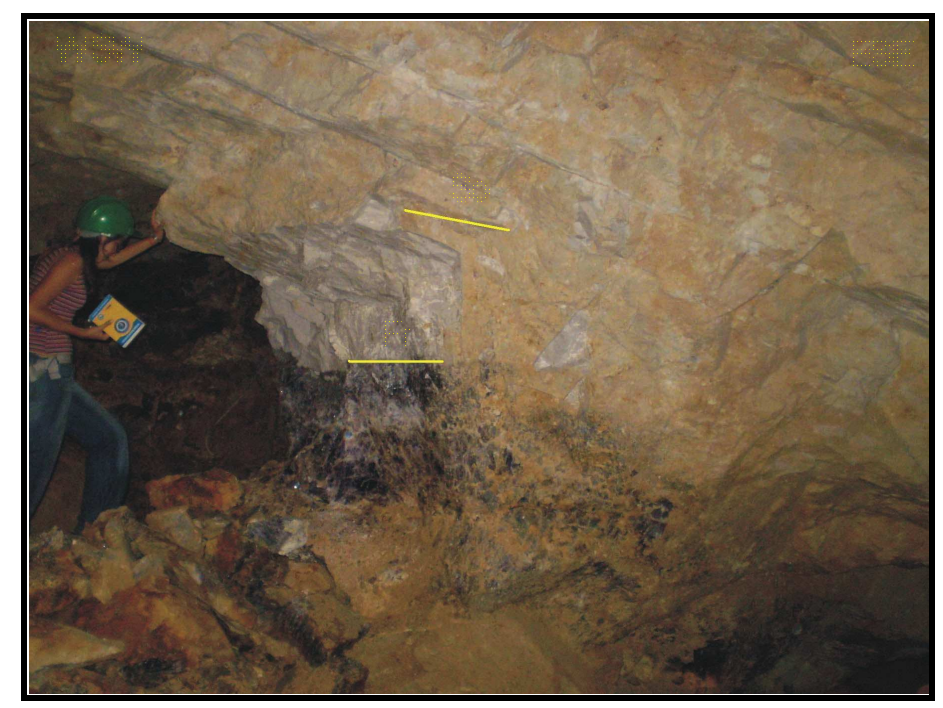

Foto 4.12: Fraturas de tração (Fr) mineralizadas encaixadas em rochas metareníticas da Formação Salto (Supergrupo Espinhaço). 


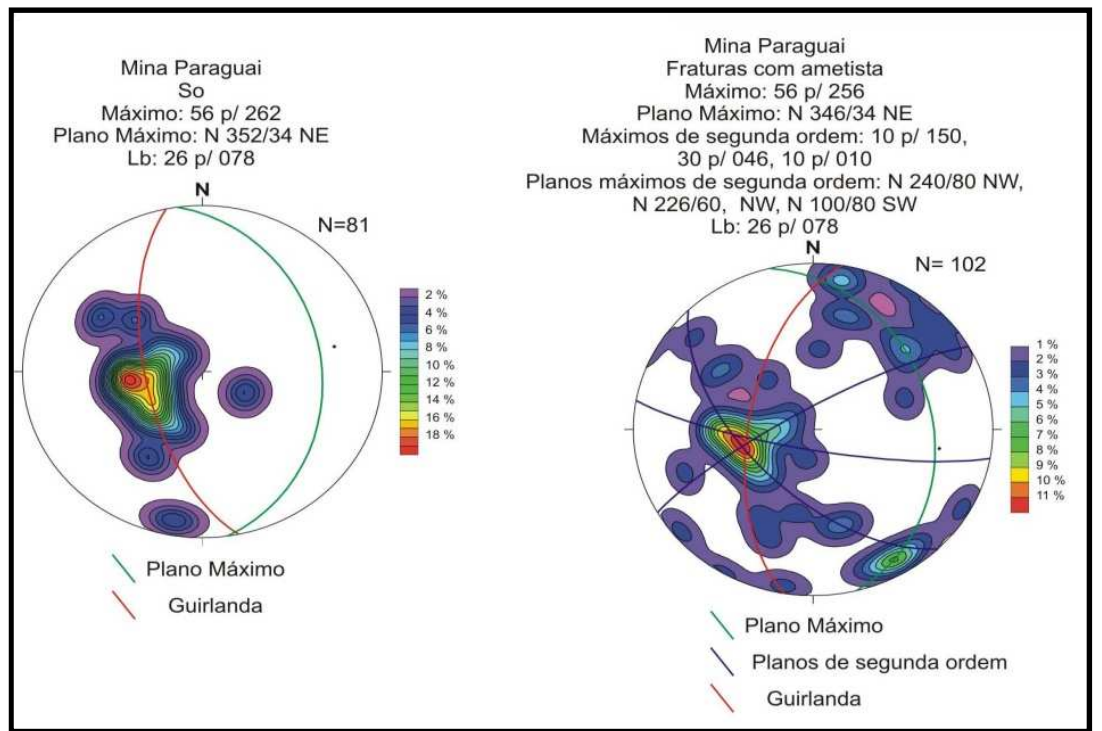

Figura 4.5: Diagramas estereográficos sinópticos para o conjunto de estruturas recuperadas na Mina Paraguai, Hemisfério inferior. $\mathrm{N}=$ Número de medidas.

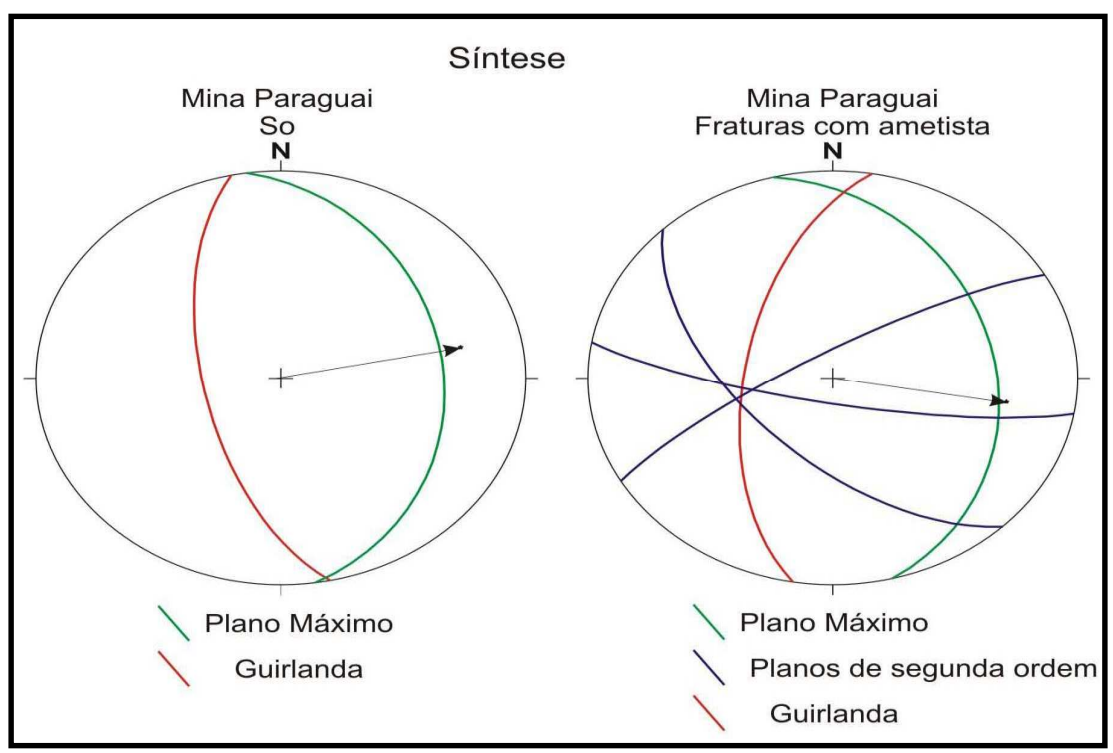

Figura 4.6: Síntese dos dados estruturais em diagramas estereográficos sinópticos

A posição das fraturas de tração com relação a essa foliação sugere um controle estrutural para a mineralização. Tais fraturas estariam, preferencialmente, relacionadas com o desenvolvimento de rampas de empurrão e zonas de cisalhamento de caráter compressional, associadas com um campo de compressão segundo ESE-WNW (Figura 4.7). 


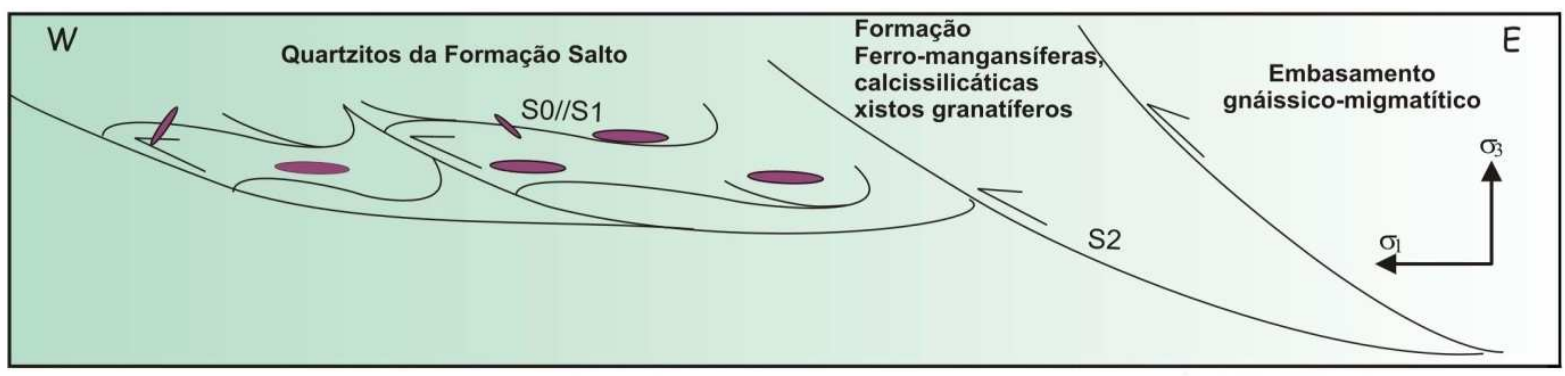

Figura 4.7: Modelo Estrutural das Fraturas de Tração em Zonas de Cisalhamento Compressionais.

Em vários trechos do garimpo, a presença de zonas de intensa fragmentação sugere a atuação de fraturamento hidráulico, possivelmente relacionado com variações na pressão de fluidos. Como demonstrado por Sibson (1990), sob regime compressional, fases de elevada pressão de fluidos são sucedidas por processos de fraturamento intenso e posterior período de baixa pressão de fluidos, com posterior alternância com períodos de alta pressão, sucessivamente.

A ametista cresce com o eixo maior em alto ângulo com o plano de fratura, compondo uma proeminente lineação de crescimento mineral. A distribuição dessa lineação é radial. Ao longo de uma mesma fratura, vários pontos de nucleação e crescimento radial da ametista podem ser verificados. Os cristais variam de tamanho, de milimétricos a centimétricos, tendo sido observados cristais com até $12 \mathrm{~cm}$ (Foto 4.13). No interior de alguns cristais observou-se um zoneamento de cor (Foto 4.14), sendo que na borda os cristais são de quartzo hialino e no centro de ametista. A presença desse zoneamento sugere uma variação na composição do fluido.

No garimpo estudado, é comum a presença de veios de quartzo leitoso cortando as fraturas preenchidas pela ametista, sugerindo fases sucessivas de injeção de fluidos nas zonas de cisalhamento (Foto 4.15). Além disso, encontram-se zonas ferruginosas associadas com os domínios de intenso fraturamento (Foto 4.16). 


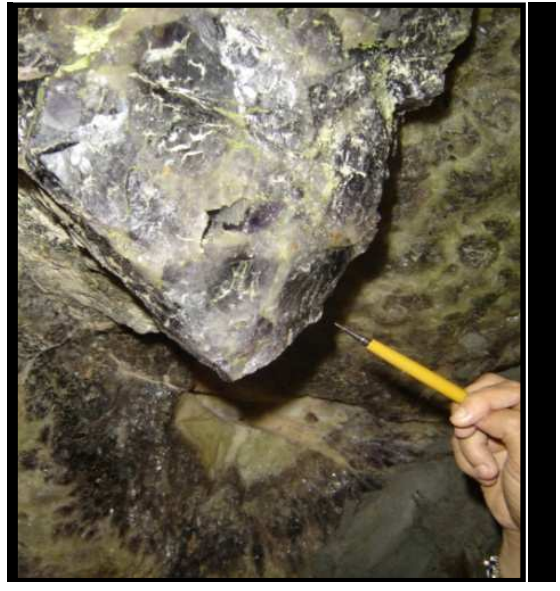

Foto 4.13: Cristal de ametista com $12 \mathrm{~cm}$

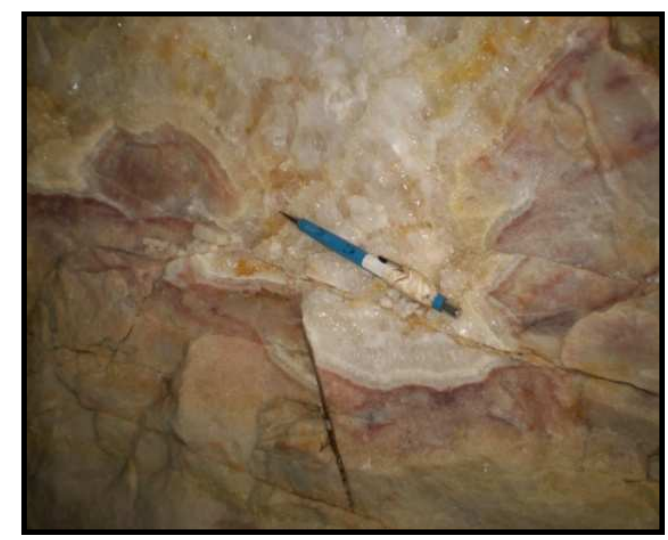

Foto 4.15: Veios de quartzo leitoso cortando fraturas

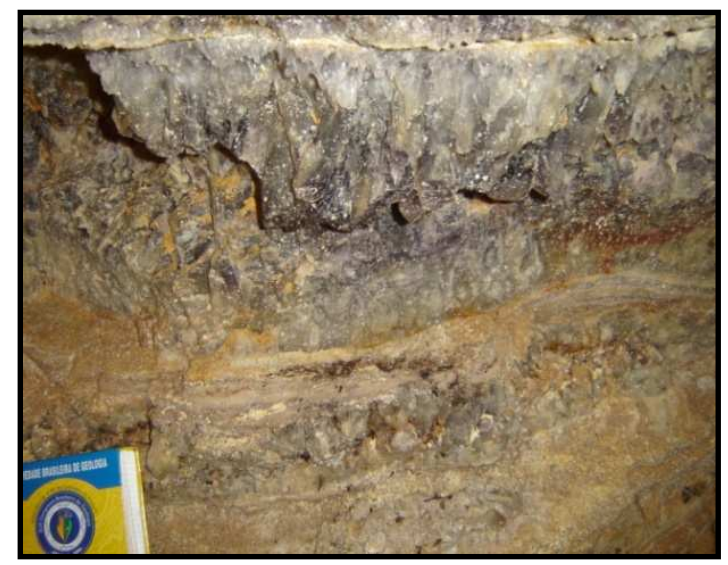

Foto 4.14: zoneamento de cor, onde na borda os cristais são de quartzo hialino e no centro de ametista

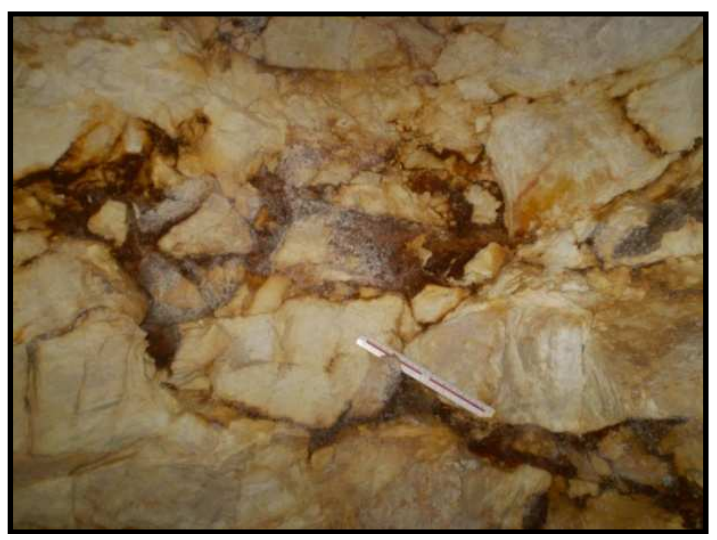

Foto 4.16: Zonas ferruginosas associadas à domínios de intenso fraturando

\subsubsection{Oliveira dos Brejinhos}

A produção de cristal-de-rocha na região se iniciou durante a II Guerra Mundial, quando a demanda da indústria bélico-eletrônica levou a atividade de garimpagem de lascas de quartzo ao seu apogeu na Bahia. Posteriormente, a atividade entrou em decadência devido a falta de demanda e queda do preço. Hoje essa prática de garimpagem é quase extinta (Luz e Braz, 2000).

O quartzo rutilado, associado ao cristal-de-rocha, é a variedade do quartzo de maior destaque econômico na região (fotos 4.17 e 4.18), na qual, de acordo com garimpeiros locais, também apresenta ocorrências de ametista, citrino e quartzo morion, que foram exploradas no passado. Mas não existem informações precisas, ou registros sobre a real existência dessas ocorrências bem como a qualidade do material destas ultimas gemas citadas (Loureiro et. al, 2009). 

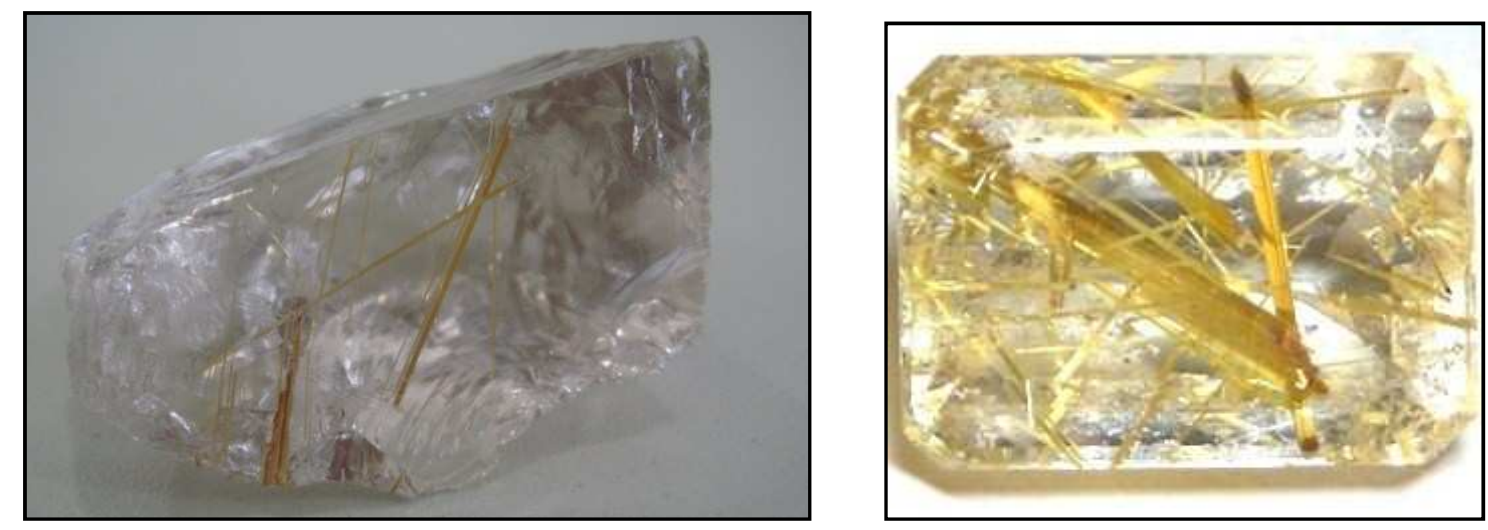

Foto 4.17 e 4.18: cristais de quartzo rutilado da região de Oliveira dos brejinhos/BA, bruto e lapidado, respectivamente.

A grande maioria das ocorrências de cristal-de-rocha encontram-se associadas com rochas metassedimentares do Grupo Paraguaçu (Supergrupo Espinhaço), na região de Oliveira dos Brejinhos. Há apenas um registro de ocorrência no domínio do embasamento, encaixado em paragnaisses do Complexo Gnaisse-Migmatítico, de idade arqueana (Couto, 2000).

Nessa região, o quartzo ocorre nas formas: primária e secundária. Os depósitos primários podem ocorrer de diversas formas, como tabular, lenticular, bolsão, irregular e chaminé, as quais são genericamente chamadas de filonianas ou filonares. Já os depósitos secundários caracterizam-se por eluvioões e coluviões, provenientes da erosão dos depósitos primários. Os depósitos secundários ainda hoje, são os primeiros a serem explorados, devido a maior facilidade dos trabalhos de exploração e garimpagem (Schobbenhaus, 1991).

De acordo com Couto (2000), a maioria dos filões é concordante a subconcordante com os metarenitos, o que sugere atitude subhorizontal dos veios. Os metarenitos feldspáticos são geralmente friáveis, o que denota alteração hidrotermal, geralmente acompanhada de formação de caulinita.

A exploração é realizada de forma rudimentar, diretamente nos filões, com o uso de ferramentas manuais, cordas e pouquíssimos explosivos (foto 4.19). Além dos filões, da mesma forma também são explorados os blocos que se encontram depositados em meio ao material coluvionar, o qual incorpora produtos da desagregação dos filões acima citado (Couto, 2000).

Segundo Loureiro et. al. (2009), o garimpo São Pedrinho, localizado na encosta oriental da Serra do Espinhaço Setentrional, apresenta "salões" (cavidades) 
com cerca de $10 \mathrm{~m}$ de diâmetro por até $5 \mathrm{~m}$ de altura. Cristais de boa qualidade de quartzo rutilado são produzidos neste garimpo, do qual já foi retirada uma pedra de $600 \mathrm{Kg}$, de excelente qualidade, dos quais cerca de $300 \mathrm{Kg}$ foram vendidos por $\mathrm{R} \$ 200.000,00$ em novembro de 2006. Outras drusas pesando cerca de $500 \mathrm{Kg}$ e $1.000 \mathrm{Kg}$, mas de menor qualidade, também já foram retiradas deste mesmo garimpo.

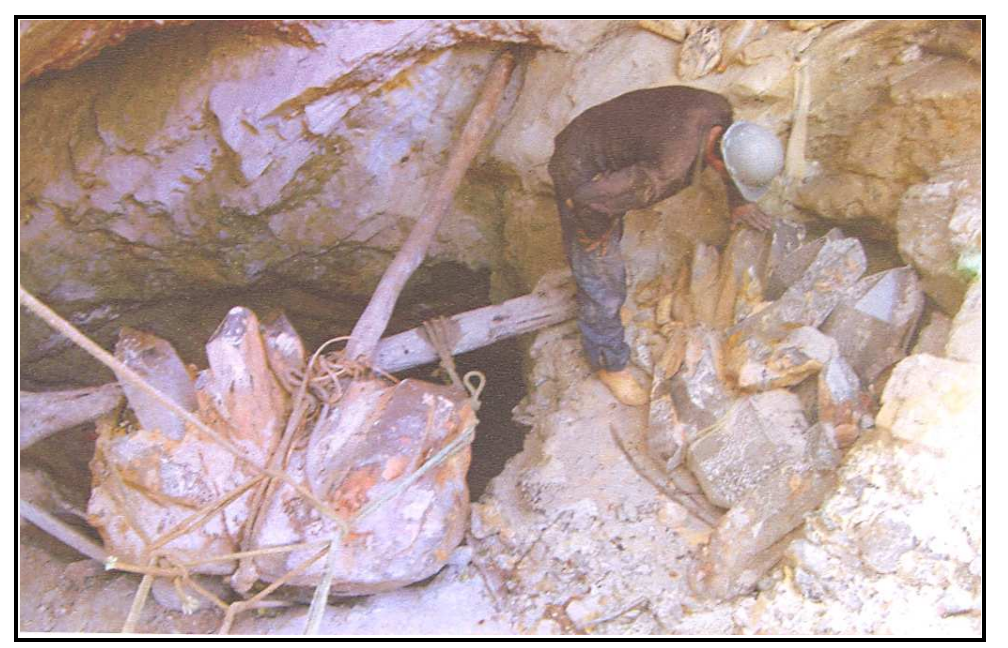

Foto 4.19: Drusas de Cristal-de-rocha, explorados de forma artesanal, no garimpo São Pedrinho, Oliveira dos Brejinhos/BA. Fonte: Loureiro (2009).

De acordo com garimpeiros da Casef (Cooperativa Agromineral Sem Fronteiras Ltda), em área de Permissão de Lavra Garimpeira, no final do ano de 2007, fragmentos translúcidos de quartzo foram aproveitados e comercializados ao preço de $\mathrm{R} \$ 40,00$ por tonelada, em alguns garimpos da região, para uso siderúrgico. (Loureiro et. al, 2009).

Atualmente, os cristais de quartzo com inclusões de rutilo, também conhecidos comercialmente por "quartzo rutilado", da região de Oliveira dos Brejinhos, tem assumido destacada importância gemológica no cenário comercial do território baiano. 


\subsubsection{Macaúbas}

Na região de Macaúbas, situada na Serra do Espinhaço, na porção do Espinhaço Setentrional, a maioria dos jazimentos de cristal-de-rocha, encontram-se inseridos, em forma de filões, em domínios de rochas quartzíticas do Grupo Serra Geral (Supergrupo Espinhaço) (Couto 2000).

Os jazimentos são explorados por meio de garimpagem artesanal, com o uso de técnicas e ferramentas rudimentares (foto 4.20). A grande maioria dos cristais produzidos nesta região são considerados de qualidade gemológica, pois apresentam na sua maioria, excelente transparência, brilho vítreo intenso e são praticamente ausentes de inclusões (foto 4.21). Segundo Couto (2000) existem boatos sobre a existência de citrinos sendo explorados na região.

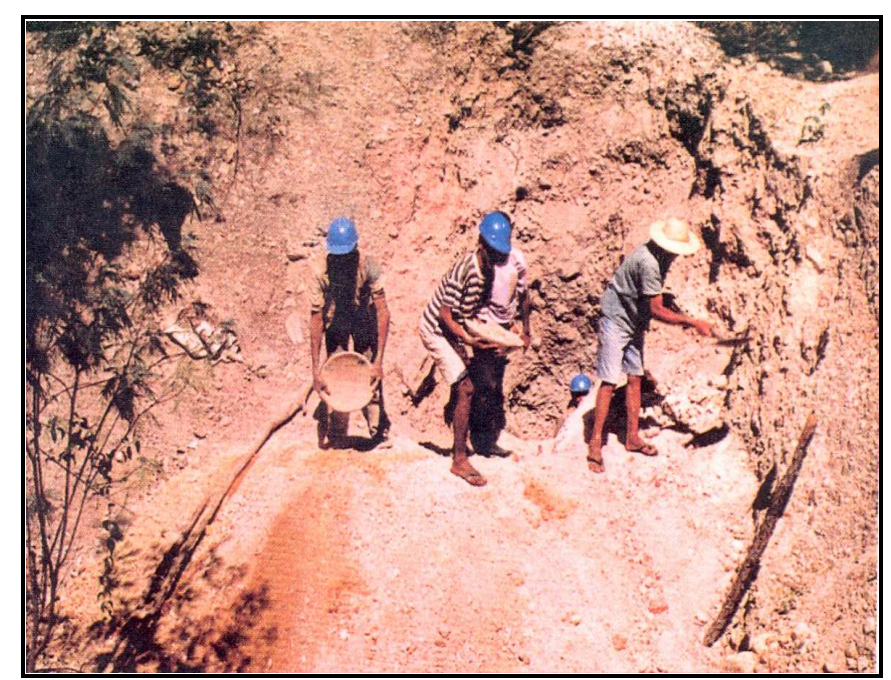

Foto 4.20: Extração de cristal-de-rocha, de forma rudimentar, em depósitos eluvionares, na região de Macaúbas-BA. Fonte: Couto (2000).

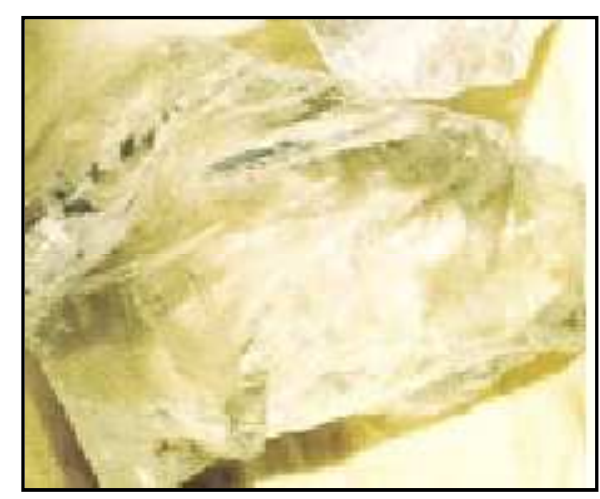

Foto 4.21: cristais de quartzo hialino de qualidade gemológica

\subsection{O Quartzo na Chapada Diamantina}

Na região da Chapada Diamantina, os principais depósitos minerais são na sua maioria, controlados por zonas de cisalhamento, e fraturas de tração.

Os quartzos da Chapada Diamantina apresentam elevado potencial gemológico, ocupando um quadro de destaque na economia mineral do Estado da Bahia. A atividade comercial envolvendo gemas, já foi uma das mais importantes fontes de renda das comunidades da região. Hoje em dia, muitas das antigas 
ocorrências de gemas conhecidas pelos garimpeiros da região, não são mais encontradas.

Dentre as gemas encontradas nesta região, tem destaque para o cristal-derocha, e o quartzo rutilado associado ao quartzo hialino, da Chapada Diamantina, e a ametista e o citrino de Sento Sé.

\subsubsection{Depósitos Estudados}

\subsubsection{Chapada Diamantina}

Durante o período da II Guerra Mundial, diversas ocorrências de cristal-derocha foram ativamente garimpadas no Brasil, principalmente na região da Chapada Diamantina. (Luz e Braz, 2000).

De acordo do Couto (2000), na região da Chapada Diamantina, os jazimentos primários de cristal-de-rocha são encontrados sob diversas formas, dentre as principais, tem-se: Filoniana: formas tabulares e contatos irregulares, com ramificações; Estratiforme: concordante com a foliação ou acamadamento da rocha encaixante; Lenticular: formas aproximadamente elípticas; e Irregular.

A grande maioria dos garimpos de cristal-de-rocha desta região encontram-se encaixadas em sedimentos pelíticos com níveis arenosos, da Formação Caboclo (Grupo Chapada Diamantina), e em menor parte, em arenitos finos a médios de aspecto recristalizado, às vezes conglomeráticos, constituintes da Formação Morro do Chapéu (Couto, 2000). Essas ultimas mineralizações, na sua maioria, estão encaixadas em veios quartzosos representando manifestações hidrotermais, as quais cortam ou concordam com as camadas das seqüências sedimentares (Foto 4.22). 


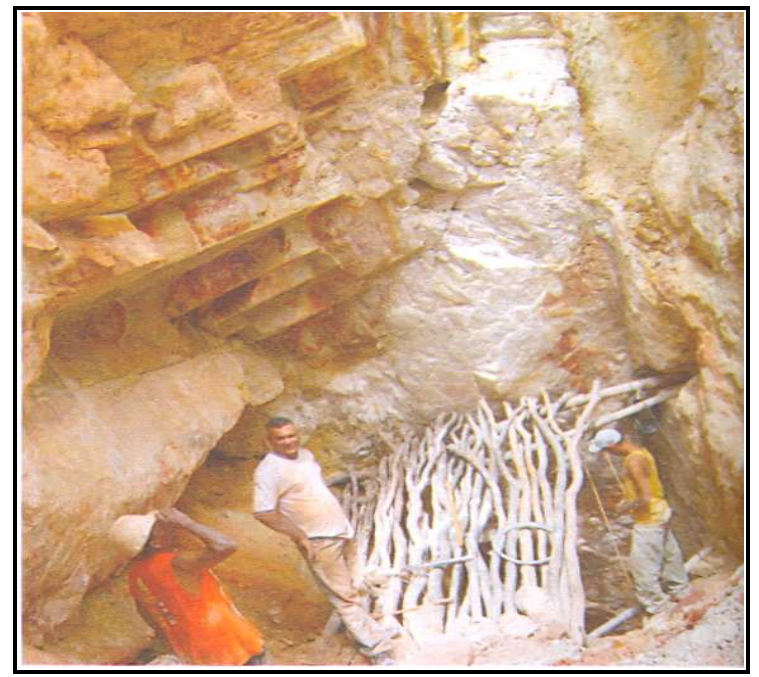

Foto 4.22: mineralizações, de veios de quartzo hidrotermal cortando as camadas das seqüências sedimentares. Fonte: Loureiro (2009).

Na maioria das vezes, os cristais de quartzo ocorrem associados tanto a veios e bolsões de quartzo leitoso, quanto a veios de pegmatitos, os quais preenchem zonas fraturadas ou seguem lineações estruturais. Essas formas ocorrem isoladamente ou combinadas no domínio de um mesmo jazimento, podendo ocorrer também blocos secundários de cristal-de-rocha em coluviões e eluviões, após desmantelamentos das formas citadas, por processos erosivos. (Bruni et. al, 1976).

Nos domínios do Grupo Chapada Diamantina, Supergrupo Espinhaço, de idade mesoproterozóica, como já mencionado, situam-se inúmeros garimpos de cristal-de-rocha, sendo que alguns deles, apresenta boa produção de exemplares com elevado potencial gemológico.

Além das ocorrências de cristal-de-rocha, na região da Chapada Diamantina, também são encontradas ocorrências de quartzo rutilado, associado ao quartzo hialino (Fotos 4.23 e 4.24).
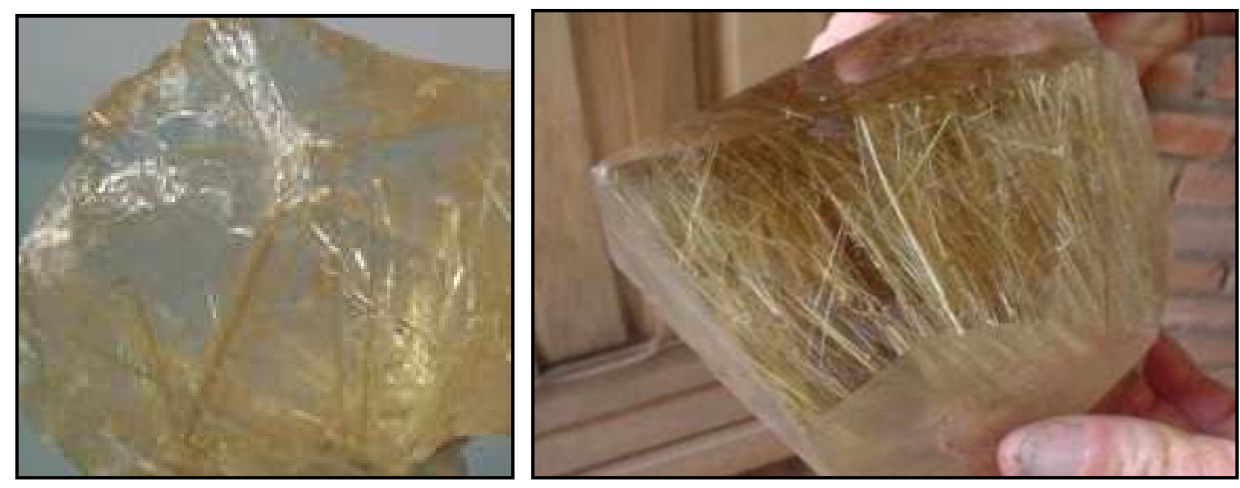

Fotos 4.23 e 4.24: cristais de quartzo rutilado associados ao quartzo hialino, da região de Ibitiara e Novo Horizonte, Chapada Diamantina/BA 
Segundo Couto (2000), as mais importantes mineralizações de cristal-derocha, com associações de quartzo rutilado, ocorrem na região de Ibitiara e Novo Horizonte (fotos 4.23 e 4.24). Essas mineralizações encontram-se encaixadas em rochas siliciclásticas metamorfizadas do Grupo Paraguaçu, (Supergrupo Espinhaço) junto às rochas vulcânicas da Formação Rio dos Remédios, na Formação Salitre (Grupo Una), ou nos domínios da cobertura vulcanossedimentar dobrada, mesoproterozóica da Chapada Diamantina Ocidental.

\subsubsection{Sento Sé}

\section{a) Ametista}

Situada as margens do lago de Sobradinho, na região do Baixo Médio São Francisco, a cidade de Sento Sé é cercada de um lado pelo Velho Chico e do outro lado por belíssimas serras. Fundada em 1832, Sento Sé está entre as cinco cidades que tiveram que ser inundadas por causa da construção da Barragem de Sobradinho. A nova cidade de Sento Sé foi erguida em 1976.

No município de Sento Sé, tem-se destaque para dois jazimentos de ametista, sendo eles, a mina da Cabeluda e o garimpo do Incaibro.

A mina da Cabeluda, situada a $35 \mathrm{Km}$ ao sul da cidade de Sento sé, foi descoberta em 1940, a qual já foi considerada uma das mais importantes jazidas produtoras de ametista do Estado da Bahia. Já o garimpo do Incaibro, distante cerca de $20 \mathrm{Km}$ a nordeste de Sento Sé, situa-se à margem direita do rio São Francisco, ao sul do lago Sobradinho, apresenta-se em forma de morro testemunho, e produz ametista de qualidade um pouco inferior às do outro jazimento citado.

De acordo com Santana et. al. (1974), as mineralizações ocorrem ao longo de falhas e fraturas, associadas a uma falha de direção NE e mergulho vertical, a qual corta os metarenitos da Formação Tombador, base do Grupo Chapada Diamantina, de idade mesoproterozóica. As escavações da mina Cabeluda situam-se na borda norte da Chapada Diamantina. 
A ametista ocorre de forma filonar (Leo, 1964), formando drusas e geodos, preenchendo cavidades, veios, fraturas, ou em cristais disseminados no arenito. Também podem ser encontrados cristais com faces bem desenvolvidas, imersos em material esbranquiçado, de fina granulação, proveniente da alteração da sericita no arenito, e cimentados por caulim, material este, que localmente é conhecido como "mocororô" (Couto, 2000).

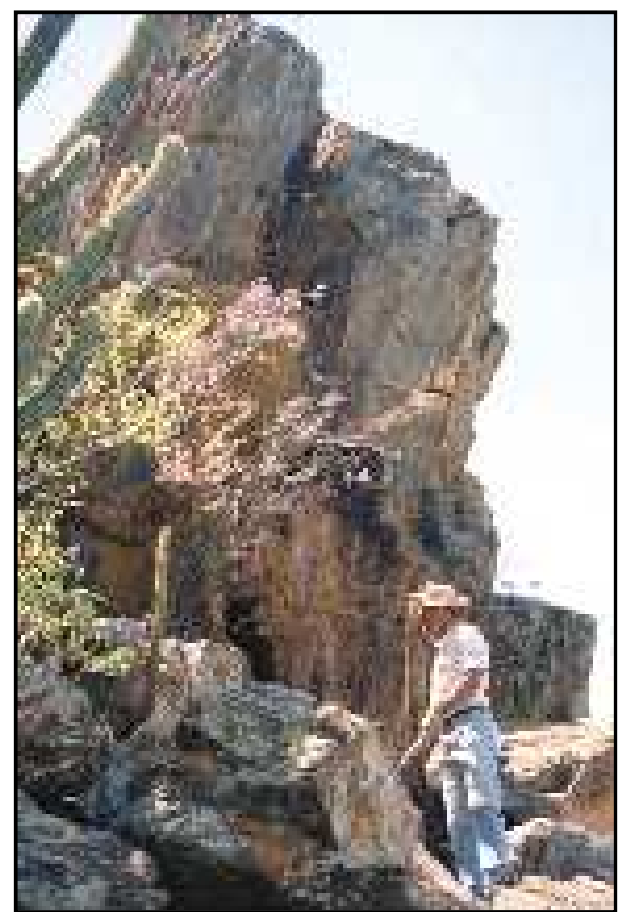

Foto 4.25: metarenitos da Formação Tombador, base do Grupo Chapada Diamantina, da região de Sento Sé/BA. Fonte Loureiro (2009).

De acordo com o mesmo autor, os arenitos friáveis da Formação Tombador (Foto 4.25), são de granulação fina a média e apresentam coloração creme claro. Nestes arenitos, além dos grãos de quartzo predominantes, foram identificados, em estudo de lâmina pretrográfica, finas palhetas de sericita e minúsculos cristais euedrais de turmalina, dispersos na rocha.

Barbosa (1965) considerou as mineralizações de ametista e quartzo hialino associado, presentes nos arenitos da Formação Tombador, como resultantes da recristalização de solução fracamente hidrotermal, a qual a sílica foi proveniente da rocha hospedeira e o caulim, dos migmatitos subjacentes. O manganês necessário à coloração da ametista, idéia vigente na época, segundo o autor, seria proveniente de camadas de arenitos cinza-escuros que se intercalam na referida Unidade do Grupo Chapada Diamantina. 
Os cristais de ametista exibem um zoneamento de base ao topo do cristal, onde o mineral vai se tornando mais corado em direção ao topo. Um zoneamento invertido pode indicar mudanças nas condições químicas ou físicas do ambiente à que a cristalização avança (Santana et. al, 1974).

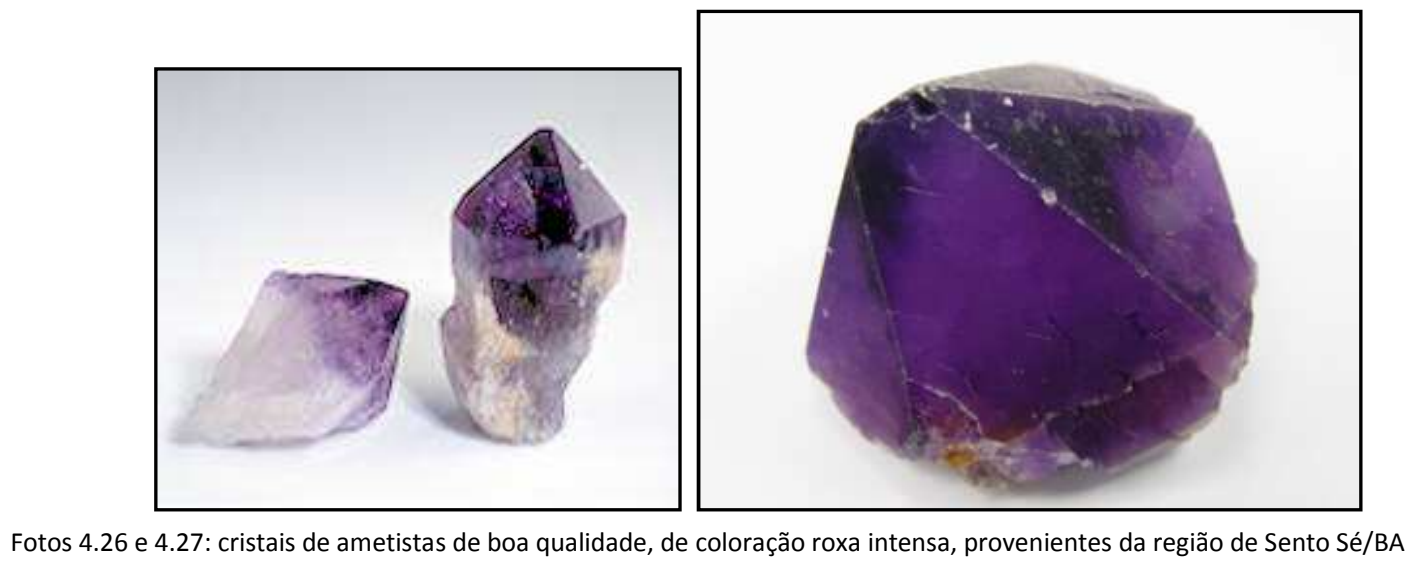

A maioria dos lotes de ametista examinados nas áreas de Incaibro e Cabeluda são de boa qualidade, apresentando boa cristalização e cor roxa intensa e uniforme (fotos 4.26 e 4.27). Outras amostras evidenciaram alternâncias de faixas de cores claras e escuras, sendo elas, incolor e lilás tendendo a violeta, de tonalidade suave e homogênea. As faixas de cor encontram-se separadas por bandas, as quais podem mostrar linhas de crescimento no cristal (Couto 2000).

Segundo Bruni et. al. (1976), foi estimada no passado, na mina Cabeluda, em regime de lavra, uma reserva de $40.000 \mathrm{~kg}$ de ametista lapidável, nas cores lilás e violeta, transparentes, e sem jaças ou inclusões. Já no garimpo do Incaibro, a produção em 1974 foi muito pequena, situando-se em torno de $54 \mathrm{Kg}$ de ametista e $364 \mathrm{Kg}$ de escórias.

\section{b) Citrino}

Localmente, na região de Sento Sé, algumas ocorrências de citrino (foto 4.28), normalmente associado ao cristal-de-rocha, são mencionadas por garimpeiros da região. Este citrino ocorre em depósitos secundários, do tipo aluviões e coluviões, como é o caso do garimpo de Careta. A ocorrência primária deste citrino, até o presente momento, ainda não foi encontrada. Novos estudos e levantamentos de 
campo são necessários para a obtenção de maiores informações sobre estas ocorrências.

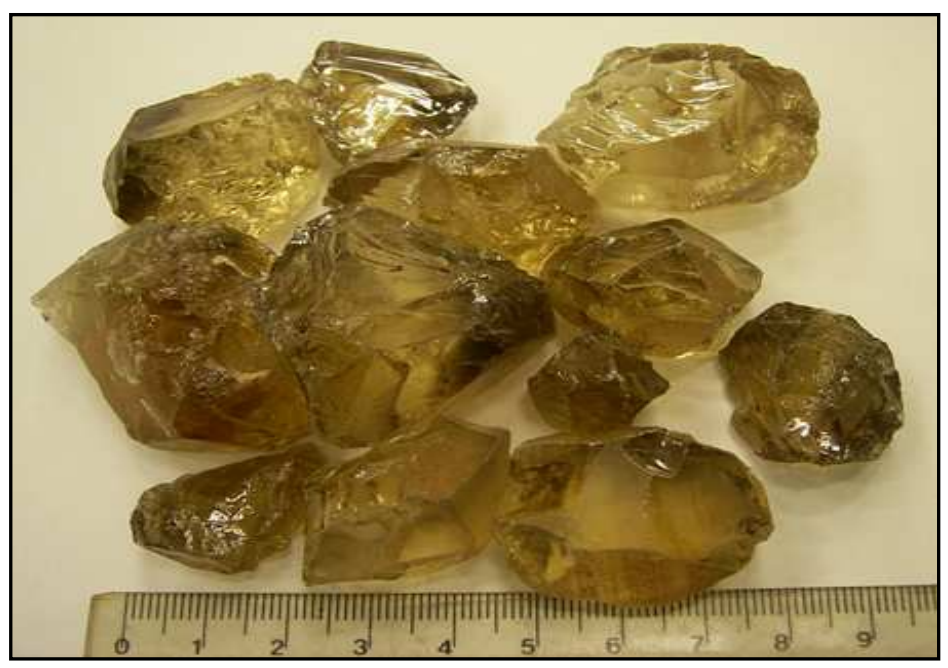

Foto 4.28: cristais de citrino natural de boa qualidade, provenientes da região de Sento Sé/BA

\subsection{O Quartzo em Jacobina}

$\mathrm{Na}$ cidade de Jacobina, encontra-se a famosa mina de ametista do Vale do Rio do Coxo, também conhecida por mina da Grota do Coxo.

Este jazimento está situado a ENE da cidade de Jacobina e a NW de Salvador, ao longo de uma falésia, no vale do riacho do Coxo, afluente do Rio Itapicuru-Mirim, ao sul da Serra de Jacobina. O acesso à área da mina se faz por $56 \mathrm{~km}$ pela estrada Capim Grosso - Jacobina e depois por estradas não pavimentadas e caminhos de serviços recortando várias vezes o riacho do Coxo (Schobbenhaus et. al, 1991).

A região de Jacobina é formada por altas serras de quartzito divididas por vales profundos. Esta jazida está inserida em um contexto representado por rochas de idade pré-cambriana, constituída por conglomerados e quartzitos da Formação Rio do Ouro na base, onde ocorre a ametista; sobrepostos por xistos associados a quartzitos micáceos amarelados da Formação Cruz das Almas; e quartzitos e filitos ferríferos e manganesíferos da Formação Água Branca no topo (Bruni et. al, 1976).

A jazida corresponde a uma zona tectonizada vertical, paralela ao vetor regional NS (Pough, 1969). Segundo Couto et. al, (1978), devido ao falhamento de 
empurrão que atingiu o Grupo Jacobina, localmente, os blocos de quartzitos encontram-se deslocados uns sobre os outros de forma imbricada, dificultando o seguimento do veio-fratura nos trabalhos de lavra.

A ametista desta mineralização, conhecida há mais de 90 anos, ocorre de forma filonar (Branco, 1984 e Leo, 1964), em cavidades ovóides, localmente conhecidas por "vugs", de 1 a 2m (Bruni et. al, 1976), geralmente em forma de geodos, grandes placas ou drusas, as quais podem ultrapassar até metros de diâmetro e extensão (foto 4.29), ocupando os espaços causados pelo fraturamento que afetou os quartzitos brechados e friáveis da Formação Rio do Ouro, pertencente ao Grupo Jacobina, de idade paleoproterozóica (Couto, 2000). Nesses quartzitos, de granulação fina e litificação variável, em alguns locais pode ser observadas marcas de ondas preservadas (foto 4.30).

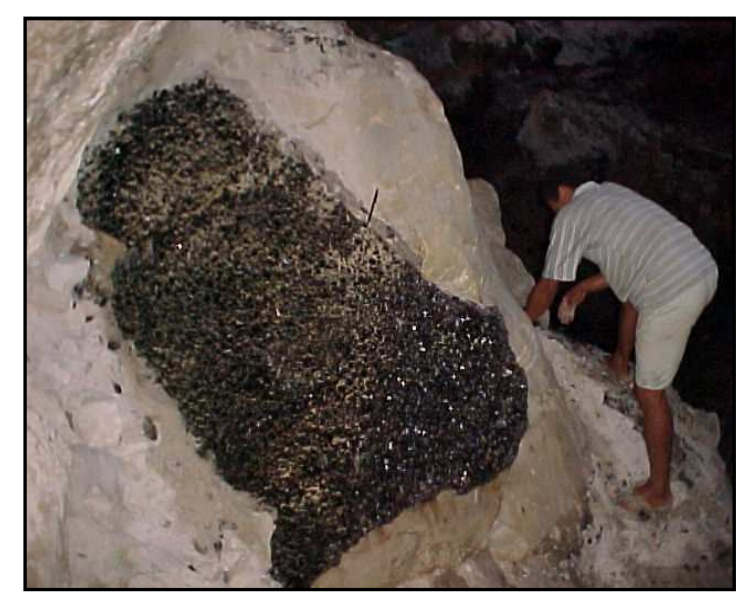

Foto 4.29: ametistas em forma de cavidades ovóides, localmente conhecidas por "vugs"

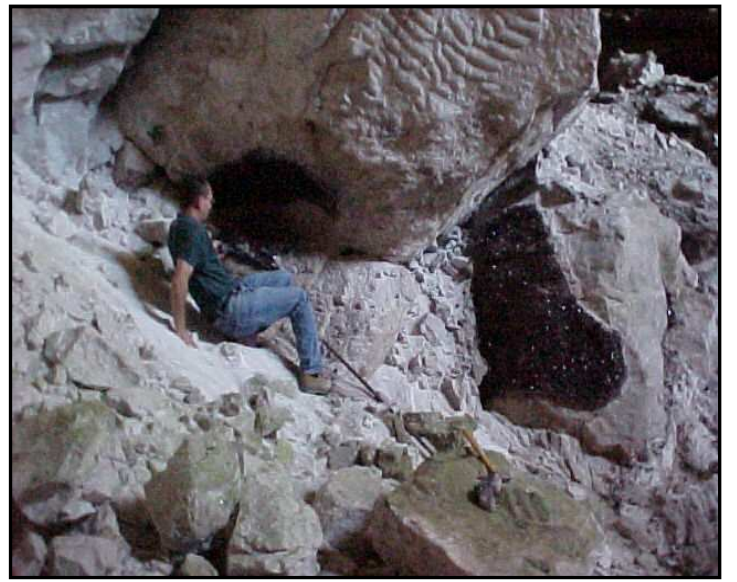

Foto 4.30: marcas de ondas preservadas nos quartzitos da Formação Rio do Ouro, Grupo Jacobina.

Existem também drusas de quartzo hialino e/ou leitoso e fumê, onde o material aparece variavelmente britado e cimentado por cristais de quartzo com um córtex ferruginoso, de coloração amarronzada, comumente opacos, denominados de "quartzo hematóide" (foto 4.31) (Cassedane \& Cassedane, 1979), característica que particulariza esta mineralização das demais encontrada no Estado da Bahia. Devido ao quartzito ser friável, placas mineralizadas soltam-se com enorme facilidade das paredes, permitindo que o material seja catado com muita facilidade. Algumas destas drusas apresentam também um preenchimento de material orgânico carbonoso. 


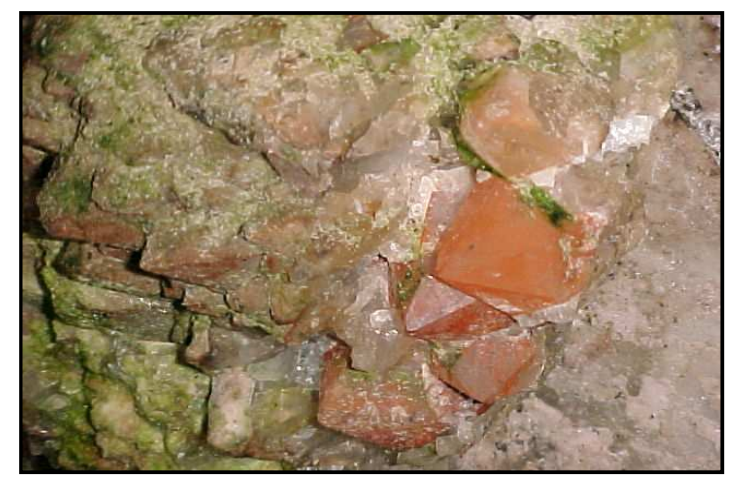

Foto 4.31: drusa de Hematóide da mina do Coxo, Jacobina/BA

De um modo geral, os cristais de ametista da Grota do Coxo variam de transparentes a translúcidos, apresentam arestas que variam de 1 a $30 \mathrm{~cm}$, e diâmetros em torno de 2 a $5 \mathrm{~cm}$, e o tamanho dos cristais pode variar de 1 a $10 \mathrm{~cm}$, podendo, mais raramente, atingir tamanhos maiores em alguns locais. A ametista possui uma tonalidade que varia de violeta com nuances avermelhados ao violetaescuro chegando por vezes a um tom aveludado extremamente apreciado no mercado de gemas.

Os cristais encontram-se formando capeamentos nas paredes das cavidades, nas quais, nem sempre os centros encontram-se preenchidos. Os eixos dos cristais são ortogonais ou levemente oblíquos às paredes de arenito (Cassedanne \& Cassedanne, 1979).

Alguns cristais mostram zoneamento de cores, arranjadas perpendicularmente ao eixo "c", indicando mudanças contínuas na solução mineralizadora. (Bruni et. al, 1976). Estes cristais quando cortados da base ao topo, ao longo do eixo "c" mostram na base, quartzo do tipo microcristalino; seguido de quartzo leitoso com algumas faixas avermelhadas paralelas às faces externas; longo corpo translúcido; e capeamento de ametista, com espessura que pode atingir alguns centímetros (fotos $4.32 ; 4.33,4.34 ; 4.35$ ). Na falta deste capeamento, passase ao quartzo ferruginoso (hematóide). Alguns cristais mostraram um capeamento de quartzo avermelhado repousando sobre um filme de pirita (com traços de cobre), recobrindo uma pirâmide de quartzo leitoso. A alteração da pirita produz cristais de quartzo encapuzados, associados a um pouco de material carbonoso. 


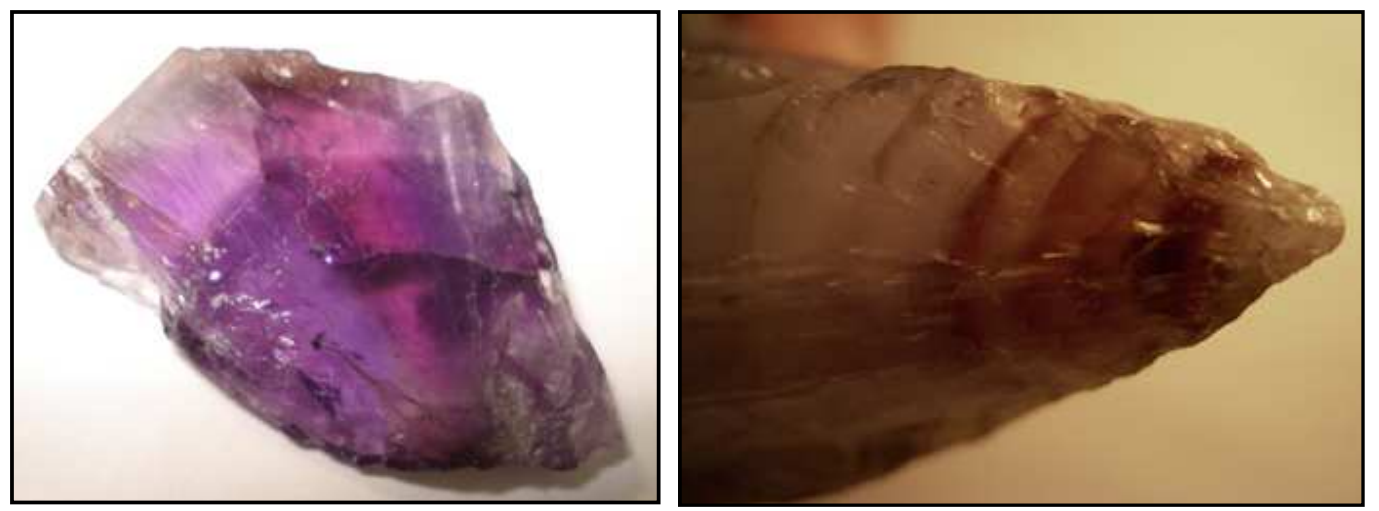

Fotos 4.32 e 4.33: zoneamento de cores arranjadas perpendicularmente ao eixo " $c$ ", em cristais de ametistas da Mina do Coxo, Jacobina/BA.
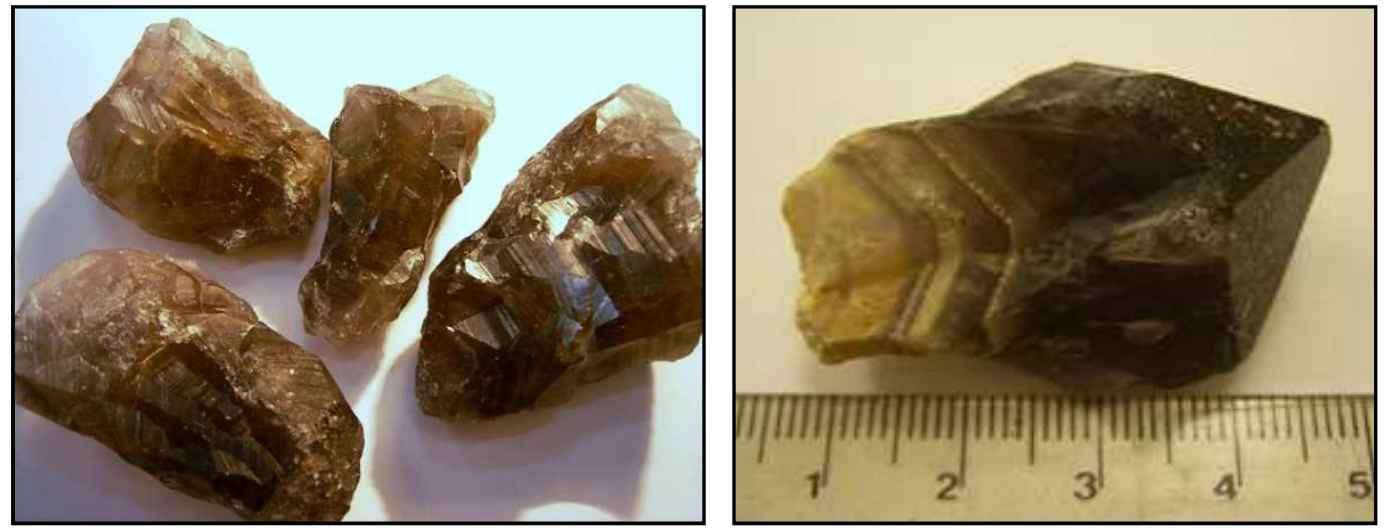

Fotos 4.34 e 4.35: zoneamento de cores e linhas de crescimento, em cristais de quartzo fumê da Mina do Coxo, Jacobina/BA.

Apesar da grande quantidade de inclusões e fraturas encontradas nos cristais, boa parte da ametista de Jacobina apresenta transparência, cor intensa e uniforme, e elevado potencial gemológico (fotos 4.36 e 4.37). De acordo com Schobbenhaus et. al, (1991), devido a sua coloração avermelhada, essa ametista já foi considerada uma das mais belas gemas do Brasil. A referida ametista também é conhecida por "Ametista Jacobina".
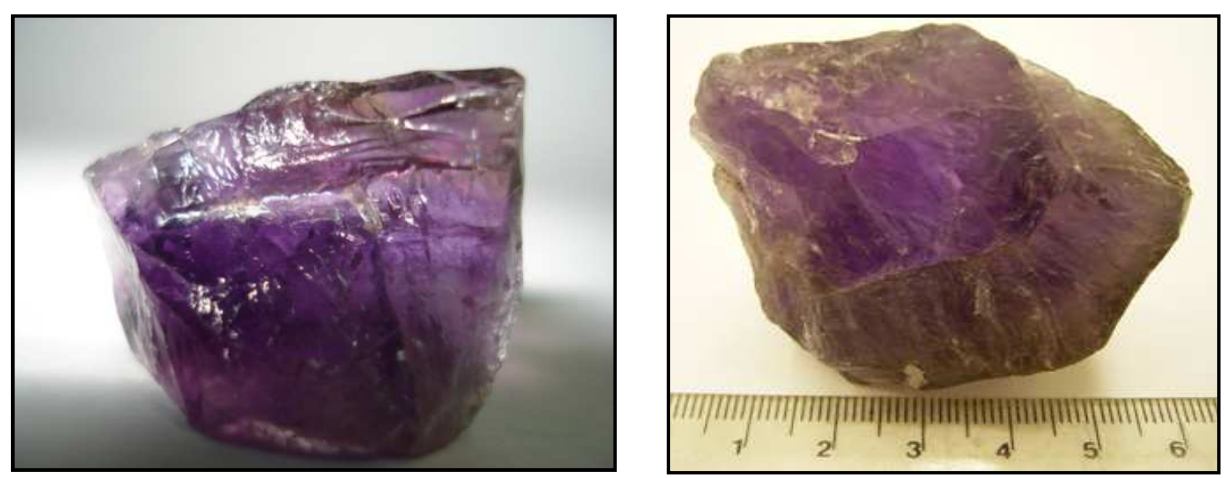

Fotos 4.36 e 4.37: cristais de ametista de boa qualidade, da Mina do Coxo, Jacobina/BA 
Amplamente distribuídas, as mineralizações de ametista já foram responsáveis por grande parte do comércio de pedras preciosas no Estado da Bahia, e a potencialidade de sua contribuição, no total produzido e arrecadado no Estado, era muito satisfatória.

Em 1976, a reserva desta mina (Figura 4.8) foi estimada em torno de $1.000 .000 \mathrm{~kg}$ de material bruto dos veios, contendo tanto ametista defeituosa (escórias) como lapidáveis (Bruni et. al, 1976).

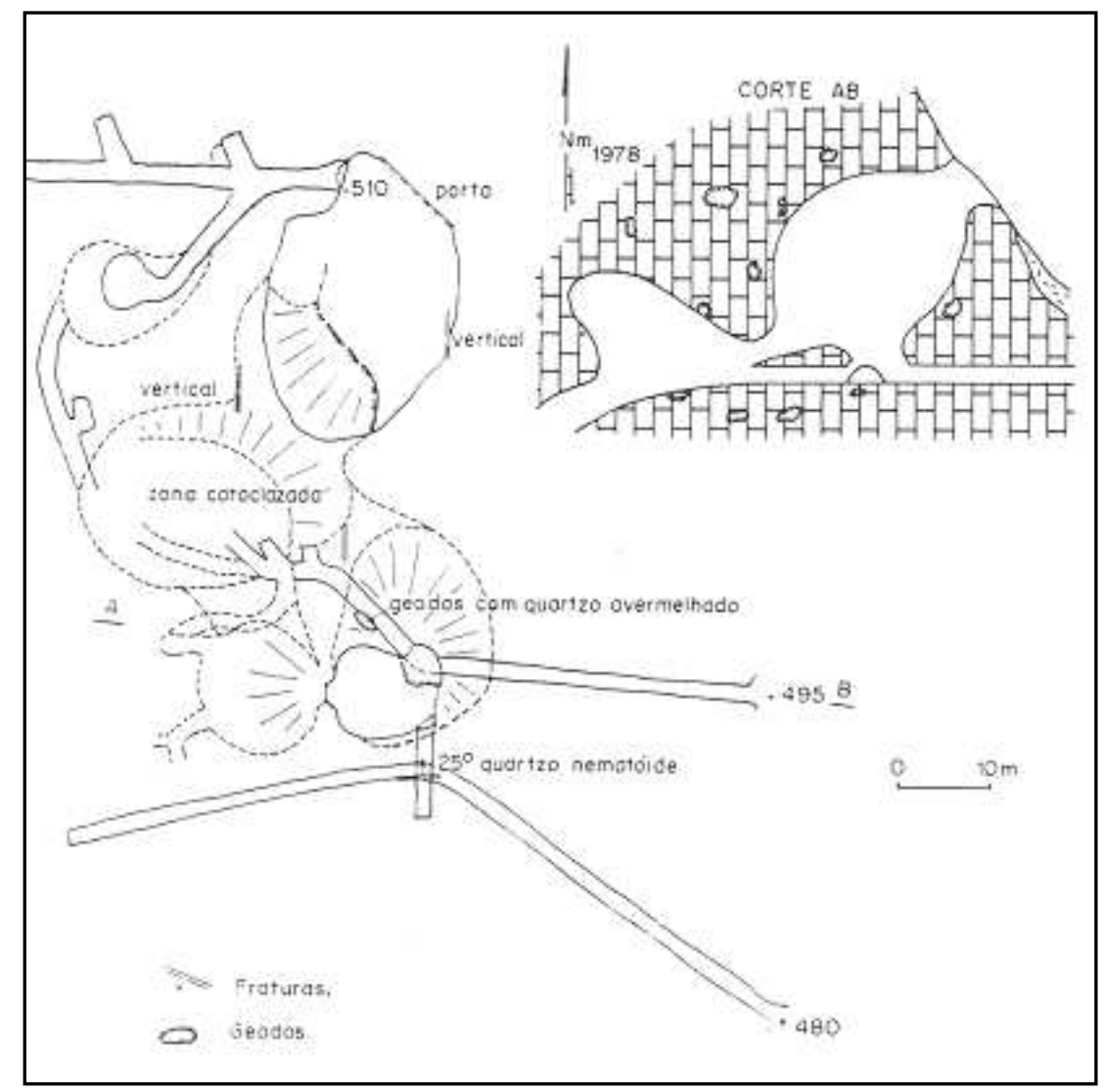

Figura 4.8: Planta da mina de ametista da Grota do Coxo. Fonte: Schobbenhaus et. al, (1991)

A lavra embora, pouco mecanizada, foi responsável pela exploração de câmaras de vários milhares de $\mathrm{m}^{3}$ (Foto 4.38). Atualmente, a mina encontra-se praticamente desativada, restando apenas um ou dois funcionários que trabalham de forma muito precária e sem infra-estrutura. 


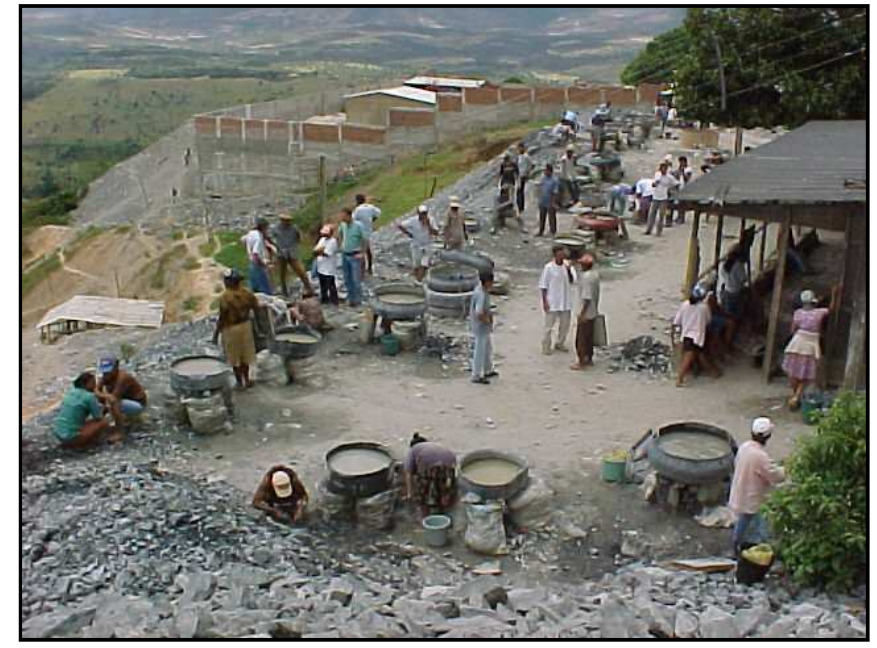

Foto 4.38: Garimpeiros na Mina do Coxo, em meados de 1976, quando ela se encontrava em plena atividade

Ainda existe um potencial razoável de ametista e hematóide a ser explorado nesta mina, mas o método de lavra deve ser aperfeiçoado e modernizado, para garantir um maior aproveitamento e uma maior redução na relação custo-benefício da produção. 


\section{CARACTERÍSTICAS MINERALÓGICAS}

\subsection{Introdução}

O quartzo é um dos minerais mais abundantes na Terra (aproximadamente $12 \%$ vol.) É denominado mineral formador de rocha, e pertence a classe dos silicatos. Mais de $60 \%$ em volume das rochas que constituem a crosta terrestre são formadas por minerais desta classe. A grande maioria dos minerais que formam as rochas magmáticas são silicatos, constituindo assim, cerca de $92 \%$ da crosta terrestre. O quartzo é o principal componente da fração arenosa do solo, e apresenta alta resistência ao intemperismo químico e físico (Lima, 2004). As principais reservas mundiais de quartzo, em volume, encontram-se no Brasil e em Madagascar.

Apesar de ser um mineral conhecido desde a antiguidade, o nome "quartzo" é de origem incerta, sendo mais provável a palavra de origem eslava, "quarz" que significa "dura" (Branco,1982).

Durante a II Guerra Mundial, o Brasil era o fornecedor de quase todo o quartzo de grau eletrônico para o mercado americano (Stoiber \& Butler, 1945). Em 1974, o governo brasileiro embargou os carregamentos de quartzo, causando uma crise no suprimento internacional, elevando em 10 vezes o seu preço.

A variação sintética do quartzo conhecida como quartzo cultivado reduziu bastante o preço do quartzo natural, deixando algumas minas inativas em países subdesenvolvidos. O quartzo cultivado tem larga utilidade na indústria eletrônica (Luz \& Braz, 2000).

\subsection{Propriedades Físicas e Ópticas}

Propriedades do quartzo, segundo Dana \& Hurlbut, (1969):

- Fórmula Química: $\mathrm{SiO}_{2}$ (Óxido de Silício, vulgarmente chamado Sílica)

- Composição: $46,7 \%$ Si - 53,3\% O

- Dureza na Escala de Mohs: Macrocristalina: 7 / Criptocristalina: 6,5 - 7

- Densidade: 2,65 
- Peso Específico: $2,6481 \mathrm{~g} / \mathrm{cm}^{3}$

- Ponto de Fusão: $1705^{\circ} \mathrm{C}$

- Ponto de Ebulição: $2477^{\circ} \mathrm{C}$

- Condutividade Térmica $(\lambda): \lambda=12,14$ paralela ao ei $\lambda=6,70$ paralelo a um eixo

- Clivagem: Não apresenta

- Fratura: Conchoidal típica, as vezes quebradiça

- Hábito : Granular, prismático, maciço

- Tenacidade: Frágil

- Cor: Habitualmente incolor ou branco, e colorido por impurezas como $\mathrm{Li}, \mathrm{Na}$, $\mathrm{Al}, \mathrm{Fe}, \mathrm{Mn}, \mathrm{Ti}, \mathrm{P}, \mathrm{H}$, entre outros.

- Traço: Incolor, branco (se puro)

- Brilho: Vítreo, gorduroso em algumas espécies

- Transparência: Transparente a translúcido

- Fluorescência: Usualmente ausente

- Índice de Refração: $\mathrm{n}_{\circ}=1,54422 / \mathrm{e}_{\mathrm{N}}=1,55332$, para $\lambda_{D}=489 \mathrm{~nm}$

- Dispersão: 0,0091-0,013

- Mineral Uniaxial Positivo

- Birrefringência: + 0,00910

- Pleocroísmo: Normalmente ausente, dicroísmo fraco é observado no quartzo fumê, ametista e citrino.

- Solubilidade: Solúvel em ácido fluorídrico

- Fusibilidade: Não é fusível

- Espectro de Absorção: Não determinável

- Propriedades Piezelétricas e Pirelétricas acentuadas

- Permissividade Relativa: $\varepsilon$ r: 4,69 paralelo a um eixo

- Comportamento em Campos Magnéticos: Diamagnético

- Pertencente a Família dos Tectossilicatos / Grupo do Quartzo

- Sistema Cristalino: Trigonal (baixa temperatura): Quartzo a 
Hexagonal (alta temperatura): Quartzo $\beta$

- Classe Cristalina: Trigonal Trapezoedral, Romboedral

- Grupo Espacial: P3 ${ }_{121}$ (lado esquerdo), P3 221 (lado direito)

- Célula Unitária: um $=4.9133, c=5.4053$, uma relação: $C=1: 1.10013 / Z=3$.

\subsection{Propriedades Químicas}

O quartzo é um composto formado por uma molécula de silício e duas moléculas de oxigênio (dióxido de silício), $\mathrm{SiO}_{2}$. Sua composição química (e do elemento silício, Si) foi descoberta pelo químico sueco Jöns Jakob Berzelius em 1823. Dióxido de silício é comumente chamado de sílica.

Em temperatura ambiente, o $\mathrm{SiO}_{2}$ é quase inerte, e não reage com a maioria das substâncias terrestres. Mesmo em altas temperaturas, a sílica é quimicamente muito estável. Por essa razão, fundidos de quartzo (vidro de sílica) são amplamente utilizados para aparelhos químicos. A razão para a baixa reatividade da sílica está na forte ligação entre seus átomos de Si-O, e também na sua estrutura macromolecular (Dana, 1978).

A sílica pode ser atacada por ácido, como o ácido fluorídrico (HF), que decompõe o quartzo para formar primeiramente SiF (fluoreto de silício), e em seguida, ácido hidro-fluoretosilício.

$\mathrm{SiO}_{2}+6 \mathrm{HF} \rightarrow \mathrm{H}_{2} \mathrm{SiF}_{6}+2 \mathrm{H}_{2} \mathrm{O}$

E também por substâncias alcalinas (como hidróxido de potássio, $\mathrm{KOH}$ ). A velocidade da reação depende da modificação e do tamanho dos cristais. O quartzo cristalino vai se dissolver muito lentamente em soluções alcalinas aquosas quentes, enquanto o quartzo amorfo será facilmente dissolvido em temperatura ambiente (Klein et. al, 1993).

Nas altas temperaturas dos vários ambientes geológicos, o quartzo atua como um ácido, e reage com muitos minerais alcalinos. Um exemplo bem conhecido é a formação do mineral wollastonita $\left(\mathrm{Ca}_{3} \mathrm{Si}_{3} \mathrm{O}_{9}\right)$, formado devido a interação de quartzo 
e calcita, em contato com processos metamórficos, sob temperaturas na faixa de $600^{\circ} \mathrm{C}$ (Dana, 1978).

$\left(\mathrm{SiO}_{2}\right)_{3}+\left(\mathrm{CaCO}_{3}\right)_{3} \rightarrow \mathrm{Ca}_{3} \mathrm{Si}_{3} \mathrm{O}_{9}+3 \mathrm{CO}_{2}$

De acordo com o mesmo autor, o quartzo é considerado "minério de silício". O silício é recuperado sob temperaturas na faixa de $2000{ }^{\circ} \mathrm{C}$, nas reações endotérmicas.

$\left(\mathrm{SiO}_{2}\right)_{2}+\mathrm{C} \rightarrow \mathrm{Si}+2 \mathrm{CO}$

A solubilidade do dióxido de silício na água depende da temperatura, pressão, estrutura e mudanças estruturais. O quartzo em temperatura ambiente é praticamente insolúvel em água. Em temperaturas acima de $100{ }^{\circ} \mathrm{C}$ e pressões elevadas, a solubilidade do quartzo aumenta rapidamente. A $300^{\circ} \mathrm{C}$, sua solubilidade encontra-se entre 700 e $1200 \mathrm{mg} / \mathrm{l}$, dependendo da pressão (Klein, et. al. 1993).

\subsection{Estrutura Cristalina}

A estrutura cristalina de um sólido é a designação dada ao conjunto de propriedades que resultam da forma como estão espacialmente ordenados os átomos ou moléculas que o constituem.

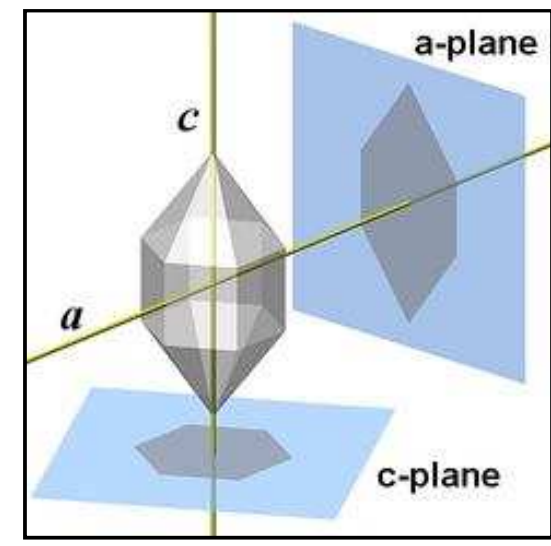

Figura 5.1: Projeção da estrutura de um cristal de quartzo em um eixo "c". Fonte: Akahavan, (2005).

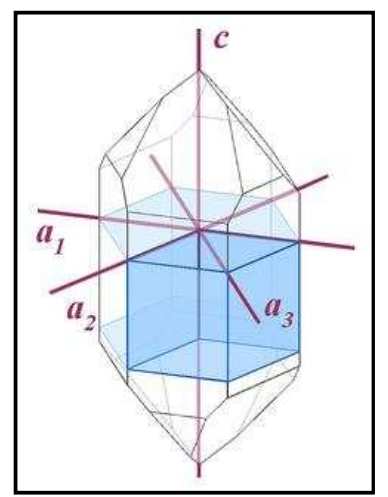

Figura 5.2: Célula Unitária (azul) e eixos cristalográficos projetados em um cristal de quartzo. Fonte: Akahavan, (2005). 


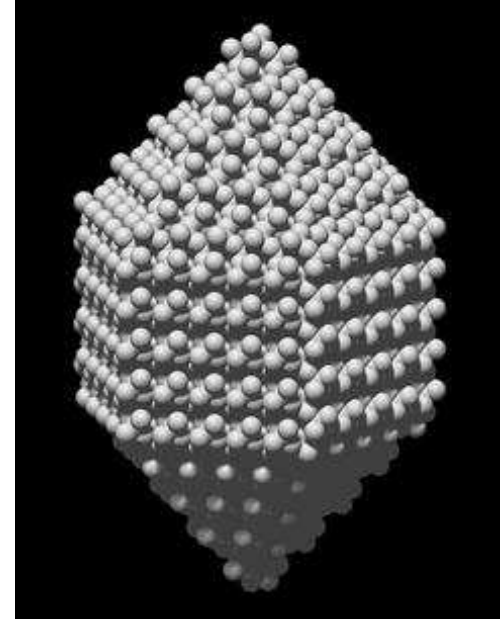

Figura 5.3: Modelo de um cristal de quartzo. Fonte: Akahavan, (2005).

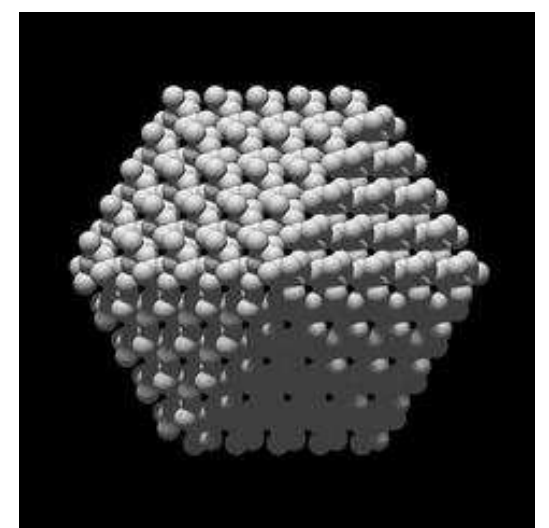

Figura 5.4: Vista superior do modelo de cristal de quartzo. Fonte: Akahavan, (2005).

Sua estrutura é formada por um retículo construído a partir de tetraedros de $\mathrm{SiO}_{4}$, onde os átomos de "Si" são coordenados por quatro átomos de "O", formando a unidade tetraédrica fundamental. Nos tectossilicatos, cada átomo de "O" está sempre compartilhado por dois tetraedros adjacentes, formando uma rede tridimensional contínua com o mais alto grau de polimerização (Dana \& Hurlbut, 1969).

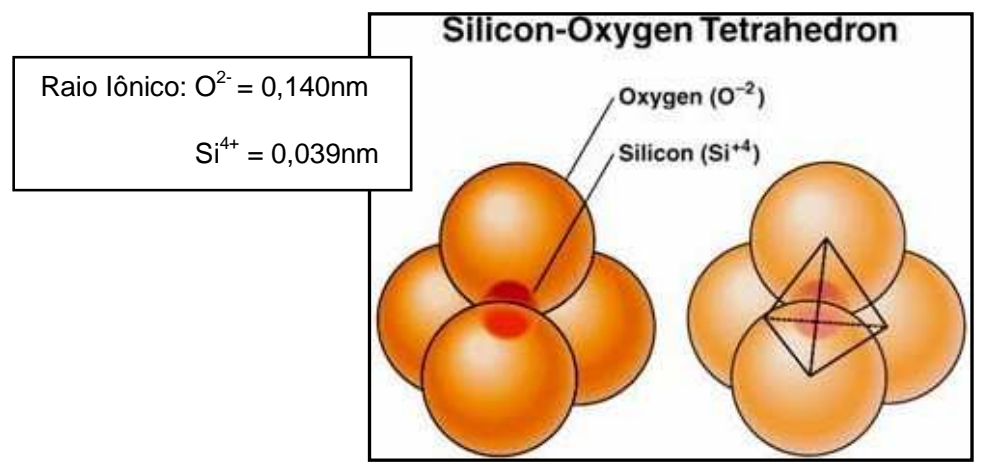

Figura 5.5: Tetraedros de $\mathrm{Si}^{4+}$ e $\mathrm{O}^{2-}$, com seus respectivos raios iônicos. Fonte: Akahavan, (2005).

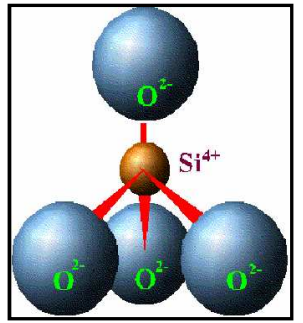

Figura 5.6: Ligação Tridimensional de tetraedros de $\mathrm{SiO}_{4}$. Fonte: Akahavan, (2005).

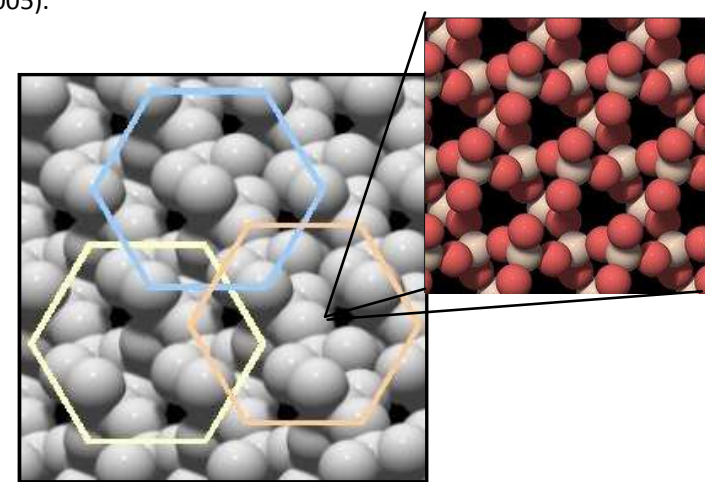

Figura 5.7: Arranjo Hexagonal de tetraedros de $\mathrm{SiO}_{4}$, átomos de silício são de cor branca e átomos de oxigênio são de cor vermelha. Fonte: Akahavan, (2005). 
De acordo com os mesmos autores, os íons de $\mathrm{O}^{2-}$ no tetraedro de Si podem igualmente partilhar os seus elétrons em ligações com outros tetraedros de $\mathrm{Si}$. As ligações Si-O e Al-O nos tetraedros contêm contribuições covalente e iônica em proporções similares, e são muito fortes.

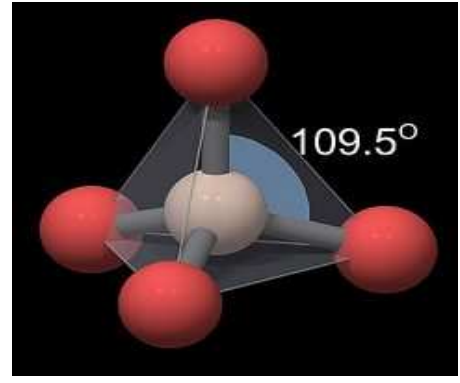

Figura 5.8: O ângulo central formado pelos átomos de O-Si-O é muito próximo ao valor ideal de um tetraedro $\left(109,5^{\circ}\right)$. Fonte: Akahavan, (2005).

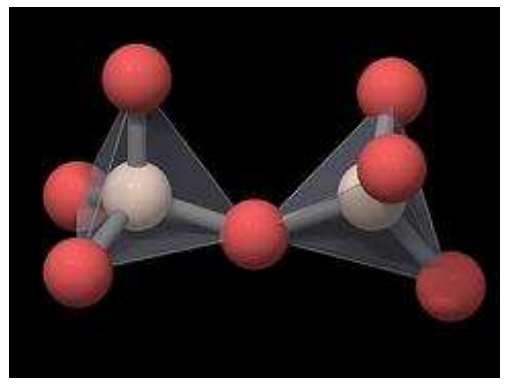

Figura 5.9: Ligação entre dois tetraedros de $\mathrm{SiO}_{4}$ Fonte: Akahavan, (2005).

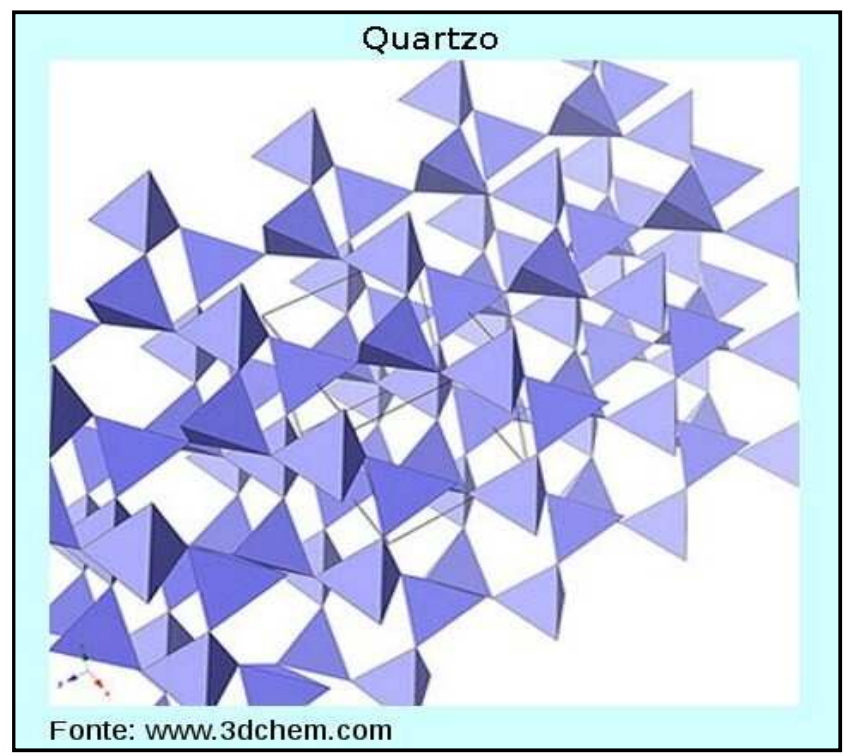

Figura 5.10: Rede de tetraedros

Os cristais de quartzo geralmente são prismáticos, com as faces do prisma estiradas horizontalmente, podendo ser alongados, em formas afiladas e pontiagudas. Normalmente formam romboedros nas suas terminações, que muitas vezes são duplas (positivo e negativo), parecendo bipirâmides hexagonais.

A lateralidade da estrutura do cristal de quartzo não é somente expresso na geometria dos cristais, mas também desempenha papel importante nas suas propriedades ópticas. $\mathrm{O}$ quartzo é uma substância opticamente ativa: ele gira o 
plano de polarização da luz que passa por ele ao longo de seu eixo "c". O Grupo Espacial do quartzo é: P3 ${ }_{1} 21$ (hélice esquerdo), $P_{3}{ }_{2} 21$ (hélice direito) (Dana, 1978).

A seguinte tabela mostra as características morfológicas, estruturais e ópticas do quartzo esquerdo e direito (Klein et. al, 1993).

Tabela 5.1: características morfológicas, estruturais e ópticas do quartzo esquerdo e direito

\begin{tabular}{|c|c|c|c|}
\hline & $\begin{array}{c}\text { Posição de } \\
\text { Faces }\end{array}$ & $\begin{array}{c}\text { Lateralidade de } \\
\text { Tripla Hélice }\end{array}$ & $\begin{array}{c}\text { Rotação de } \\
\text { Plano de Polarização }\end{array}$ \\
\hline Quartzo Esquerdo & esquerdo & $\begin{array}{c}\text { direito } \\
\text { (sentido horário) }\end{array}$ & $\begin{array}{c}\text { direito } \\
\text { (sentido horário) }\end{array}$ \\
\hline Quartzo Direito & direito & $\begin{array}{c}\text { esquerda } \\
\text { (sentido anti-horário) }\end{array}$ & $\begin{array}{c}\text { esquerda } \\
\text { (sentido anti-horário) }\end{array}$ \\
\hline
\end{tabular}

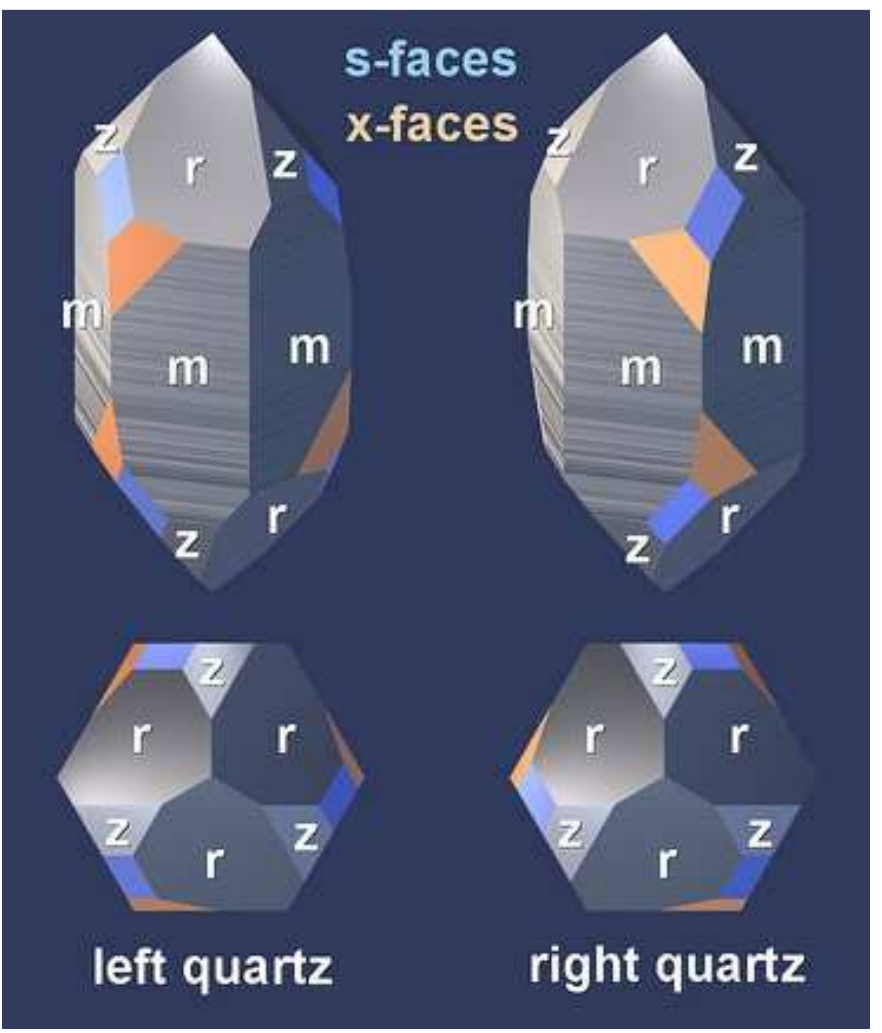

Figura 5.11: Morfologia dos cristais de quartzo direito e esquerdo. As faces menores são X, S e Z, localizadas à esquerda do observador no quartzo esquerdo, e à direita, no quartzo direito. Fonte: Akahavan, (2005). 


\subsection{Hábito}

Assim como as faces de um cristal, que se desenvolvem de acordo com o ambiente de formação do cristal, o hábito de um cristal reflete as condições de crescimento individuais dos cristais, em diferentes ambientes (Branco, 1982). Dentre os principais hábitos observados nos cristais de quartzo estudos, tem-se:

a) Cristais Biterminados: corresponde a uma combinação de romboedros positivos e negativos, que muitas vezes são desenvolvidos de maneira tão igual a ponto de culminarem na formação de uma bipirâmide hexagonal.

b) Cristais Laser ou Agulha: corresponde a cristais que se desenvolvem desproporcionalmente ao longo do eixo "c", assemelhando-se a uma grande barra ou agulhas, podendo os mesmos ocorrerem isoladamente ou em drusas. Seu crescimento é devido a quedas bruscas de temperatura e/ou pressão, indicando ambiente tectonicamente ativo. O quartzo Laser é comumente encontrado na região da Serra do Espinhaço.

c) Cristais Prismáticos: são os mais comuns, nos quais os cristais se mostram de forma bem desenvolvida, chegando perto da forma "ideal" do cristal. Quando ocorrem isolados das drusas, são conhecidos como "Dentes-deCão", ou "Polegares".

d) Cristais Tipo Catedral: correspondem a cristais cujas linhas de crescimento descrevem feições geométricas. São também conhecidos como "Barracado". Cristais com esse hábito são encontrados com freqüência nas Serras do Espinhaço e Jacobina.

e) Quartzo Fantasma: ocorre quando inclusões minerais tais como clorita, hematita e quartzo impuro ou leitoso, se amoldam ou se formam ao longo dos planos de crescimento, criando um aspecto nevoado no cristal, dando a impressão da existência de um outro cristal dentro do cristal de quartzo, como se fosse um cristal fantasma. 
f) Cristais Oblatos: corresponde a um achatamento do cristal ao longo dos eixos $Z$ ou $X$, ou de duas de suas faces prismáticas. Cristais com esse hábito são encontrados com freqüência em certas regiões da Serra do Espinhaço. $O$ crescimento desses cristais se dá em ambientes de cristalização com pressão moderada, o que não permite que o cristal se desenvolva livremente.

\subsection{Geminação}

De acordo com Dana \& Hurlbut (1969), geminação é um intercrescimento entre dois cristais da mesma espécie, com algumas relações cristalográficas entre as duas partes. Em termos da estrutura atômica, a relação espacial é um plano ou uma fileira reticular que é comum a ambas as partes. Em termos de geometria, a relação é tal que uma parte pode girar (normalmente $180^{\circ}$ ) em torno de um eixo (eixo de geminação) na direção de orientação da outra. Freqüentemente, uma parte é a imagem especular da outra a partir de um plano (plano de geminação).

A geminação pode ser de contato ou de penetração. Os geminados de contato tem uma superfície de contato de composição definida separando os dois indivíduos, enquanto que os geminados de penetração, são constituídos por indivíduos que se interpenetram tendo uma superfície irregular de contato, ou um eixo de geminação (Dana \& Hurlbut, 1969). Ainda segundo os autores, a geminação pode ser simples, quando apenas dois cristais estão unidos, ou polissintética, quando ocorre intercrescimento de vários cristais em orientações geminadas.

O quartzo da Bahia mostra com freqüência, diversos tipos de geminação. Dentre as principais formas de geminação do quartzo, tem-se:

a) Lei do Brasil: apresenta o plano do cristal geminado perpendicular a um dos eixos cristalográficos do cristal. Desta forma, os indivíduos, "esquerdo" e "direito", encontram-se formando um geminado de penetração.

b) Lei de Dauphiné: é uma geminação de penetração, na qual o cristal geminado utiliza como seu eixo, o eixo "c" do outro cristal. Cristais geminados nesta lei encontram-se formando compostos de dois elementos direitos, ou de dois elementos esquerdos. 
c) Lei do Japão: corresponde a cristais cujo plano do cristal geminado encontrase paralelo a um romboedro $\{1122\}$.

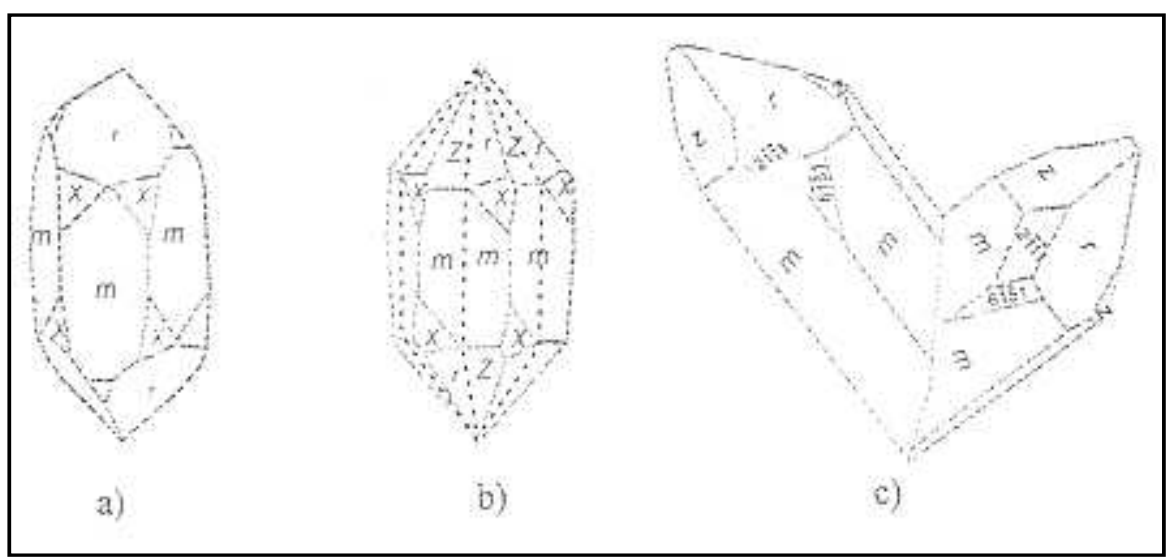

Figura 5.12: Tipos de geminação encontradas em cristais de quartzo da Bahia; a) geminação do Brasil, b) geminação Lei de Dauphiné, c) geminação Leio do Japão. Modificado de Dana \& Hurlbut, (1969)

\subsection{Principais Polimorfos}

Propriedades dos principais polimorfos, segundo Dana \& Hurlbut, (1969):
a) Tridimita $-\mathrm{SiO}_{2}$

- Sistema Cristalino: Ortorrômbico ( $\alpha$ ), Pseudo-hexagonal ( $\beta$ )

- Cristais normalmente pequenos e geminados

- Dureza: 7

- Densidade: 2,26

- Brilho: Vítreo

- Cor: Incolor a branco

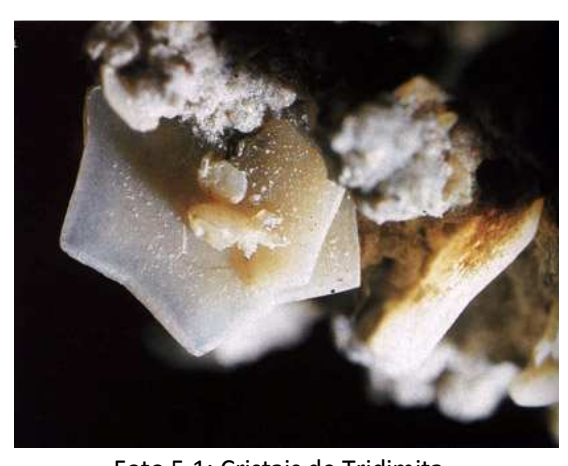

Foto 5.1: Cristais de Tridimita

- Estável somente entre $870-1470$ ㄷ

- Caráter biaxial positivo 


\section{b) Cristobalita $-\mathrm{SiO}_{2}$}

- Sistema Cristalino: Tetragonal ( $\alpha$ ), Pseudo-isométrico ou cúbico ( $\beta$ )

- Pequenos cristais octaedros

- Dureza: 7

- Densidade: 2,30

- Brilho: Vítreo

- Cor: Incolor

- Estável somente acima de 1470

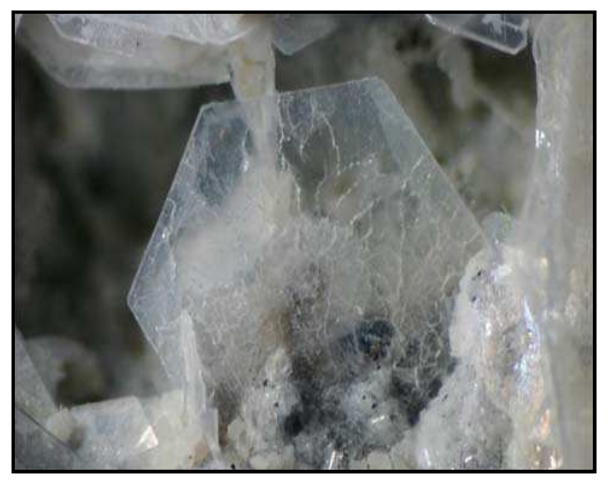

Foto 5.2: Cristais de Cristobalita

- Caráter uniaxial negativo

A tridimita e a cristobalita têm birrefringências inferiores às do quartzo, e relevos moderados negativos, com índices de refração próximos a 1,48, ou pouco maiores para a cristobalita (Dana, 1978).

Ocorrem em algumas rochas vulcânicas intermediárias a ácidas, como andesitos, dacitos e riolitos, em geral preenchendo cavidades de lavas. A cristobalita aparece mais freqüentemente como produto de cristalização magmática tardia ou da inversão polimórfica da tridimita. Já a tridimita é um produto típico do metamorfismo pneumatolítico, burial, ou "de carga", sendo comum nas seqüências vulcanosedimentares recentes da cordilheira dos Andes (Klein et. al, 1993).

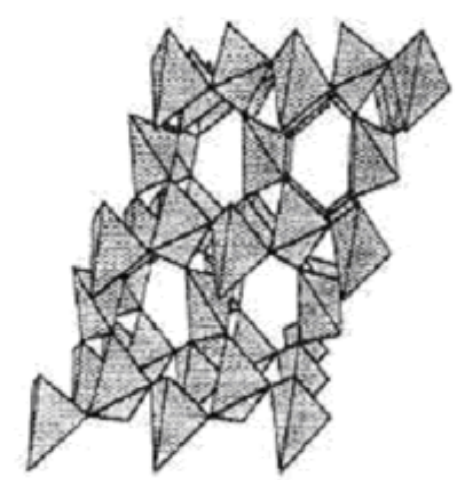

a)

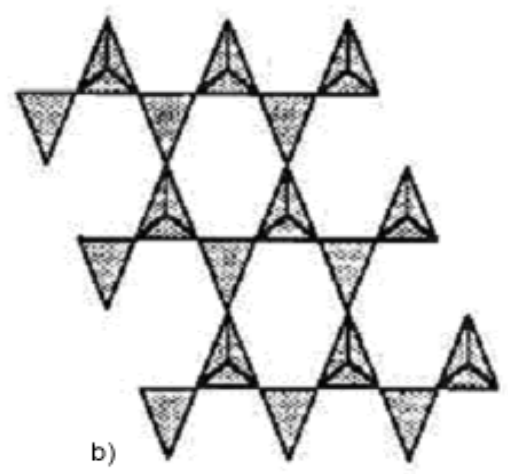

Figura 5.13: Representações das estruturas poliédricas do quartzo (a) e da tridimita e cristobalita (b) Fonte: Dana (1979) 


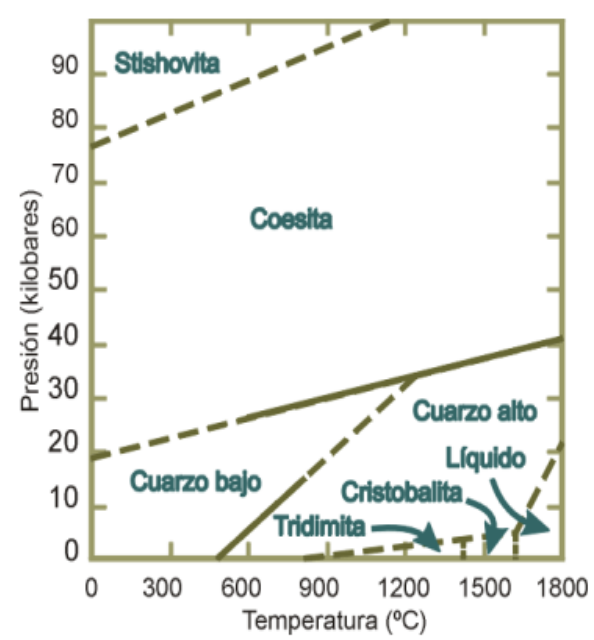

Figura 5.14: Diagrama dos campos de estabilidade em função da P e T das fases polimórficas de sílica. Fonte: Klein (1993)

\subsection{Inclusões}

Inclusões, na definição gemológica, são quaisquer irregularidades, corpo estranho ou defeito que esteja no interior de um mineral. Qualquer que seja sua origem, sua natureza, composição ou gênese, é tida como um importante elemento diagnóstico na diferenciação das gemas naturais das sintéticas (Lima, 2004).

As inclusões nos minerais são muito freqüentes, sejam da mesma espécie (por exemplo: diamante dentro de outro diamante) ou de espécies diferentes (por exemplo: zircão dentro da safira).

As inclusões fluidas são pequenos volumes de fluidos que ficam aprisionados nos minerais durante ou após a sua formação. $O$ quartzo e um dos minerais hospedeiros mais adequados devido a sua grande estabilidade em um amplo intervalo de pressão e temperatura, ausência de clivagem, alta dureza e abundancia. É o mineral que melhor preserva as inclusões fluidas que se formam durante a sua cristalização, ou em processos posteriores (Pasquali, 1992).

A maioria das inclusões é considerada como desvalorizadora dos minerais gemas, pois estas influenciam na cor, nos fenômenos ópticos e na resistência mecânica dos mesmos. No entanto, existem inclusões que justamente agem como característica principal de alguns minerais, tais como: efeito olho-de-gato, dendritas, 
e inclusões de agulhas de rutilo no quartzo, causando o fenômeno do asterismo (Branco, 1982).

O quartzo é uma das espécies minerais com maior variedade de inclusões. As inclusões no quartzo podem ser protogenéticas, singenéticas ou epigenéticas. A maior parte das inclusões no quartzo são singenéticas (Klein et. al, 1993).

As Inclusões mais comuns encontradas no quartzo são de goethita, hematita, magnetita, ouro, rutilo, enxofre, turmalina, fluorita, manganês, calcita, pirita, clorita, mica, zircão, granada, pirolusita, entre outros.
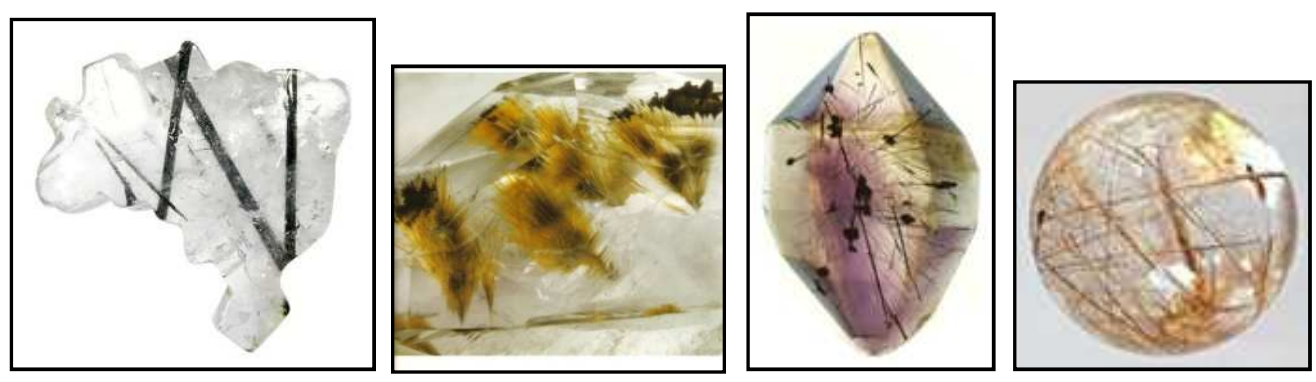

Fotos 5. 3, 5. 4, 5. 5, 5. 6: Inclusões mais comumente encontradas no quartzo; turmalina, hematita, gohetita, rutilo, respectivamente.

\subsection{Aplicações}

A ausência de centro de simetria em cristais de quartzo, e a sua transparência resultam em propriedades características, com destaque para a atividade óptica e a piezeletricidade, as quais tornam este mineral peça importante para as indústrias ópticas e eletro-eletrônicas.

A atividade óptica está relacionada ao poder do cristal de rotacionar o plano de polarização da luz, isto é, realizar uma polarização rotativa, que pode ser direita ou esquerda em relação à orientação original do plano de vibração da luz, o qual caminha paralelamente ao eixo cristalográfico "c" (Dana, 1978).

A piezeletricidade é a propriedade de um cristal de desenvolver polaridade elétrica por meio da migração de cargas elétricas ao longo de uma direção reticular (eixo polar), quando se aplica um esforço mecânico ao longo dele. O quartzo, em particular, apresenta piezeletricidade reversa, que é a propriedade de um cristal se 
expandir ao longo do eixo polar quando uma corrente elétrica flui por ele em um sentido, e contrair quando o sentido da corrente é invertido (Dana \& Hurlbut, 1969).

Quartzo natural, obtido a partir de depósitos de areia, saprólitos graníticos e agregados de quartzo (arenitos e quartzitos), tem diversas aplicações na construção civil, e é a matéria prima essencial para a fabricação de vidros e de algumas cerâmicas (Lima, 2004). O emprego do quartzo nos diversos segmentos industriais é função do conteúdo de impurezas, defeitos na estrutura do cristal, e outras especificações.

Algumas variedades coloridas do quartzo, com cristais bem formados, alto brilho, transparência elevada, cor uniforme, e baixo índice de inclusões, podem apresentar caráter gemológico, os quais são destinados a joalherias e a fins esotéricos (Branco, 1984).

Segundo Luz et. al. (2003), o cristal de quartzo pode ser utilizado em sua forma natural ou como quartzo cultivado (por crescimento hidrotermal, em autoclave). Atualmente, quase todas as aplicações piezelétricas e de óptica são atendidas pelo quartzo cultivado. No Brasil não se verifica a produção do quartzo cultivado, entretanto os grandes cristais naturais, utilizados como sementes para a produção de quartzo cultivado são aqui encontrados e exportados.

As lascas de quartzo de alta pureza, além de serem usadas na produção de quartzo cultivado, são também empregadas na produção do quartzo fundido, e de carga para microcircuitos de alta integração (Arcoverde, 1988; Iwasaki et. al, 1991). O quartzo fundido é empregado em uma vasta gama de indústrias de alto valor agregado, como: óptica, equipamentos elétricos e eletrônicos, química de base, cerâmicas especiais e de precisão, fibra óptica, entre outros (Luz \& Braz, 2000).

Devido à sua grande importância técnica, sua abundância, e seu papel nos processos geológicos, o quartzo provavelmente é um dos minerais mais estudados nos últimos tempos, mas ainda nem tudo sobre ele pode ser compreendido. 
De acordo com Luz \& Braz (2000), as principais aplicações dos produtos de quartzo nas indústrias são:

\begin{tabular}{|c|c|}
\hline Indústrias & Uso e Aplicações \\
\hline Telecomunicação & osciladores, filtros, fibra óptica, silicones e chips \\
\hline Relojoaria & osciladores, silicones, células fotovoltaicas e sensores \\
\hline Química & $\begin{array}{l}\text { transdutores, tubos para difusão, vidraria especial, ampolas, } \\
\text { cadinhos, silicones, tubos de sílica, vasilhames e vidraria } \\
\text { em geral, fabricação de tintas, lixas, massas para polimento, } \\
\text { saponáceos, esmaltes, abrasivos }\end{array}$ \\
\hline Óptica & $\begin{array}{l}\text { vidro óptico, vidraria especial, placas de sílica, blocos de } \\
\text { sílica, silicones, detentores e abrasivos, lentes e prismas }\end{array}$ \\
\hline Metalúrgica & $\begin{array}{l}\text { tubos de sílica, aços especiais, ligas especiais, silicones, } \\
\text { refratários, resistores }\end{array}$ \\
\hline Equipamento Médico & $\begin{array}{l}\text { osciladores, tubos de sílica, fibra óptica, vidraria especial, } \\
\text { cadinho, silicones, chips, vidros planos, vasilhames e } \\
\text { vidraria em geral }\end{array}$ \\
\hline Eletrônica & $\begin{array}{l}\text { osciladores, filtros, transdutores, tubos de sílica, tubos para } \\
\text { difusão, vidraria especial, silicones, células fotovoltaicas, } \\
\text { transdutores, transistores, tiristores, sensores, chips e } \\
\text { detentores }\end{array}$ \\
\hline Eletrodoméstica & osciladores, silicones, transistores, tiristores e chips \\
\hline Elétrica & $\begin{array}{l}\text { tubos de sílica, bulbos, ampolas, silicones, bastões de } \\
\text { sílica, refratários e resistores, ligas de silício, cálcio-silício, } \\
\text { ferro-silício-magnésio, ferro-silício e silício metálico }\end{array}$ \\
\hline Construção Civil & $\begin{array}{l}\text { aços especiais, ligas especiais, silicones, refratários, vidros } \\
\text { planos e areia, cerâmicas, porcelanas, moldes de fundição, } \\
\text { argamassa, concreto, pedras para revestimento, tijolos de } \\
\text { sílica }\end{array}$ \\
\hline Computação & osciladores, silicones e chips \\
\hline Bélica & $\begin{array}{l}\text { osciladores, filtros, sensores, transdutores, lã de sílica, fios } \\
\text { de sílica, aços especiais, ligas especiais, silicones, células } \\
\text { fotovoltaicas, chips, detentores, abrasivos e refratários }\end{array}$ \\
\hline Automobilística & $\begin{array}{l}\text { sensores, transdutores, fibra óptica, vidraria especial, aços } \\
\text { especiais, ligas especiais, silicones, transistores, tiristores, } \\
\text { chips, detentores e vidros planos }\end{array}$ \\
\hline Gemológica & material ornamental, joalheria, esoterismo \\
\hline
\end{tabular}




\section{VARIEDADES COLORIDAS DO QUARTZO MACROCRISTALINO}

\subsection{Introdução}

Se puro, o quartzo é incolor, transparente, cristalino e muito rígido. Dentre as principais variedades coloridas, tem-se a ametista (violeta), citrino (amarelo), quartzo fumê (cinza a marrom), quartzo rosa, quartzo verde, quartzo azul, entre outros. $O$ quartzo também ocorre em formas densas, sem cristais visíveis, e muitas vezes multi-coloridos, como é o caso das calcedônias e ágatas.

No entanto, é possível classificar as variedades do quartzo, devido a sua formação, em dois grandes grupos: "quartzo macrocristalino" e "quartzo criptocristalino".

A tabela 6.1 a seguir enumera os fatores que promovem ou inibem a formação das variedades macrocristalina e criptocristalina do quartzo (Dana, 1978).

Tabela 6.1: Fatores para a formação das variedades macrocristalina e criptocristalina do quartzo

\begin{tabular}{|l|l|l|}
\hline Macrocristalina & Fatores Favoráveis & Fatores Desfavoráveis \\
\hline & $\begin{array}{l}\text { Temperaturas acima de } 150^{\circ} \mathrm{C} \\
\text { silício em soluções aquosas } \\
\text { Presença de eletrólitos em } \\
\text { soluções aquosas. }\end{array}$ & $\begin{array}{l}\text { Temperaturas abaixo de } 100^{\circ} \mathrm{C} \\
\text { Altas concentrações de silício em } \\
\text { soluções aquosas }\end{array}$ \\
\hline Criptocristalina & $\begin{array}{l}\text { Temperaturas abaixo de } 150{ }^{\circ} \mathrm{C} \\
\text { Altas concentrações de silício } \\
\text { em soluções aquosas }\end{array}$ & $\begin{array}{l}\text { Temperaturas acima de } 2000^{\circ} \mathrm{C} \\
\text { Presença de eletrólitos em } \\
\text { soluções aquosas } \\
\text { Ausência de água }\end{array}$ \\
\hline
\end{tabular}

Outros fatores, como pressão, e ausência ou presença de água líquida, também podem desempenhar um papel importante na formação das variedades macrocristalina e criptocristalina do quartzo. 
De um modo geral, as variedades macrocristalinas do quartzo compreendem aqueles minerais que apresentam cristais bem definidos, ou que possuem uma estrutura cristalina macroscopicamente visível. Neste caso, as variedades macrocristalinas do quartzo serão descritas de acordo com sua cor.

\subsection{Origem da cor}

Uma das primeiras propriedades ópticas observadas em um mineral é a sua cor, que, em alguns casos, é de suma importância para ajudar na sua identificação, mas na maioria deles, a cor é uma das propriedades mais variáveis, não podendo ser usada como uma propriedade diagnóstica.

A cor é um fenômeno que ocorre nos cristais quando eles absorvem, refletem ou transmitem a luz. Ela não é causada apenas pela composição química do mineral, mas também pela presença de inclusões, pelo seu arranjo atômico e por impurezas e defeitos na sua estrutura cristalina (Dana, 1978).

A cor é a resposta do olho à escala de luz visível do espectro eletromagnético e da absorção dos comprimentos de onda dentro do espectro visível, que se estendem de $375 \mathrm{~nm}$ a $740 \mathrm{~nm}$ ) ( $\mathrm{nm}=$ nanômetro, $1 \mathrm{~nm}=10$ angstroms) (figura 6.1). Uma gema tem a cor do comprimento da onda que ela não absorve, ou seja, as gemas negras ou muito escuras têm essa cor devido a absorção total do espectro de luz. Já quando elas não absorvem nenhum comprimento de onda, e toda a luz as atravessa, são incolores. Quando a absorção da luz é seletiva, a gema irá ter a cor ou a mistura de cores que não forem absorvidas (Klein, 2002). 


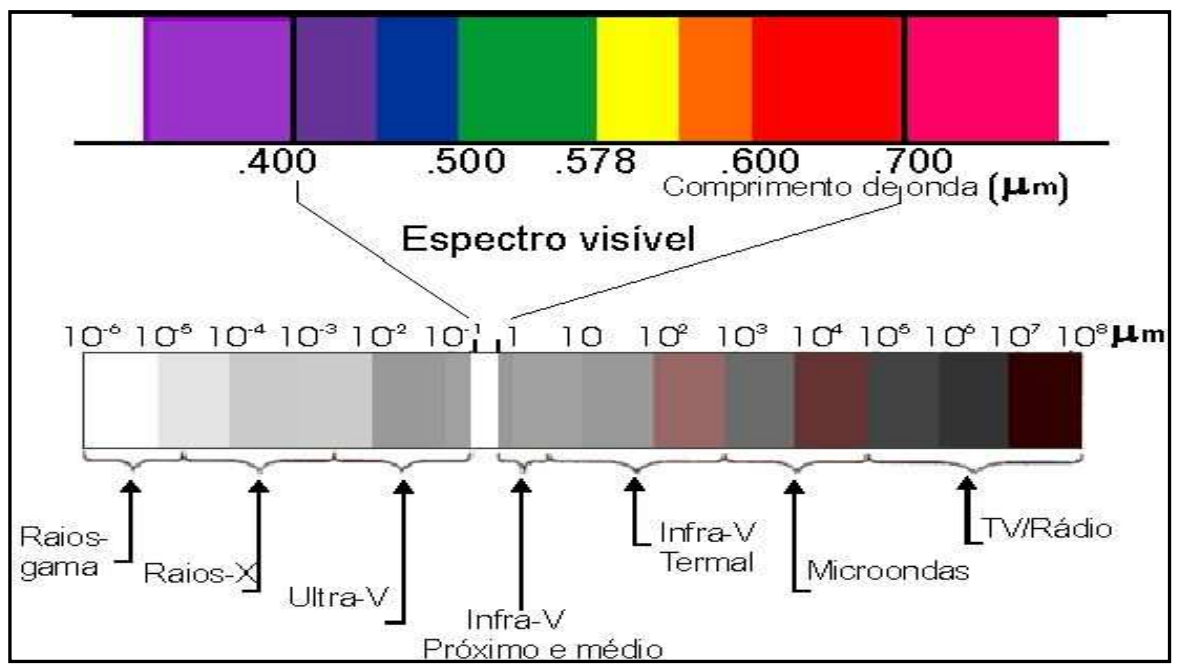

Figura 6.1: O espectro eletromagnético. O quartzo absorve comprimentos de ondas dentro da faixa dos espectros visível, ultravioleta e infravermelho. $O$ espectro visível abrange a faixa que vai de $375 \mathrm{~nm}$ a aproximadamente $740 \mathrm{~nm}$. Modificado de Klein (2002).

Ao longo dos séculos, muitas foram as teorias, desenvolvidas por artistas, cientistas, filósofos e pensadores, como Newton, Goethe, Rouge, Munsell e Wilhelm, com o objetivo de compreender e definir a cor (Lima, 2004). Em 1931, foi desenvolvido o sistema de cores CIE, conhecido pelo seu Diagrama de Cromaticidade (XYZ), no qual não estão representadas apenas as cores puras monocromáticas, como também, as misturas delas para cada coordenada cromática (Figura 6.2). Esse diagrama compreende uma das primeiras gamas de cores matematicamente definidas.

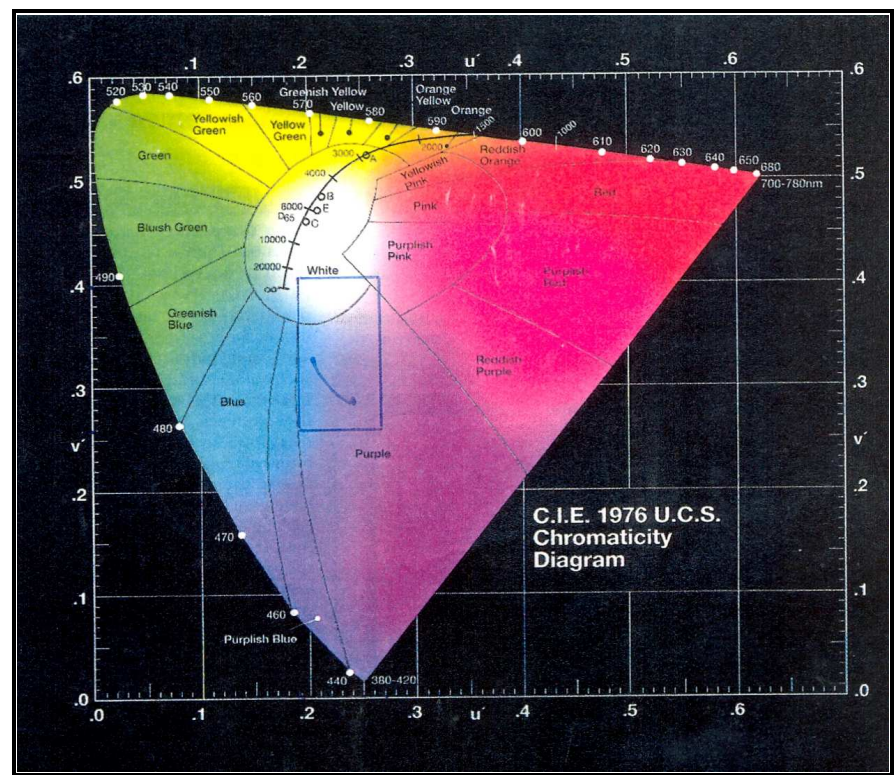

Figura 6.2: Diagrama de Cromaticidade (XYZ), onde A variável $Y$ corresponde ao brilho, enquanto que as variáveis $X$ e $Z$ se referem ao tom e a saturação. 
A origem da cor no quartzo pode estar relacionada a quatro fatores principais, sendo eles: a) íons metálicos, b) centros de cor, c) transferência de carga, e d) inclusões minerais; os quais serão descritos a seguir.

\section{a) Íons Metálicos}

A coloração do quartzo pode ser resultado da absorção de determinados comprimentos de ondas do espectro visível devido a presença de íons metálicos em sua estrutura.

Segundo Fyfe (1964), os elétrons de um átomo movem-se ao redor dele, em camadas denominadas de orbitais, os quais constituem níveis distintos de energia. A absorção de determinados comprimentos de onda no espectro visível ocorre quando estes elétrons, com a incidência da luz natural, saltam para outros orbitais de maior energia, fazendo com que essa mudança de orbital seja igual a energia da luz absorvida.

De acordo com Fritsch \& Rossman, (1987), a mudança de orbitais por parte dos elétrons de um íon é denominado de "transição". Essa transição corresponde a passagem de um elétron do estado de repouso para um estado de excitação, fator este que irá gerar a cor do mineral. Este estado de excitação é normalmente instável, o que leva o elétron a voltar ao seu estado de repouso, liberando energia na forma de calor, ou de luminescência (Figura 6.3).

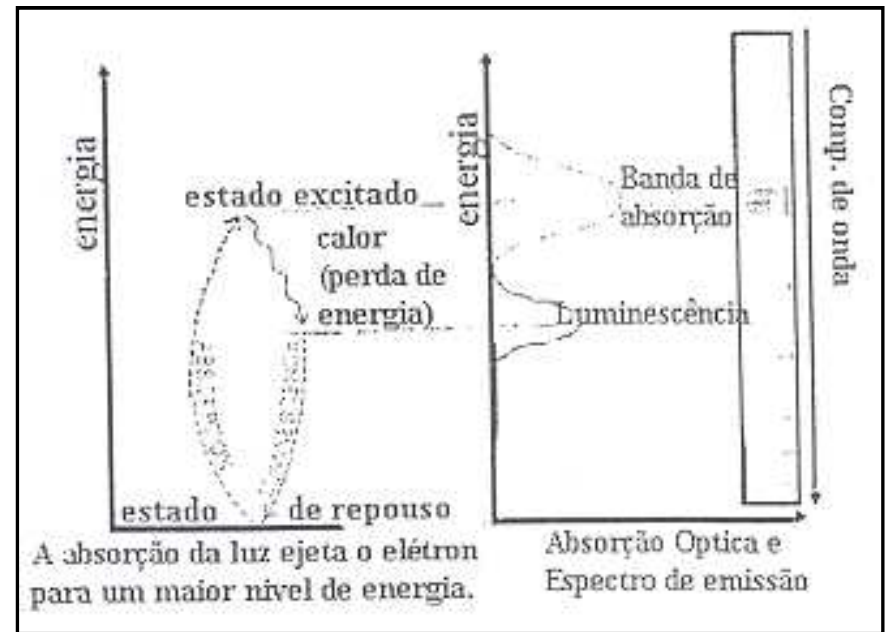

Figura 6.3: Desenho esquemático do espectro de absorção de luz por um mineral. Quando um cristal absorve luz, os elétrons são levados de um nível de baixa energia (estado de repouso), a um nível de alta energia (estado de excitação). Essa energia perdida é dissipada na forma de calor ou luminescência, ao elétron voltar ao seu estado de repouso. Fonte Fritsch \& Rossman, (1987). 
A grande variedade colorida do quartzo é proveniente da exposição a radiações naturais, de alta energia, devido a elevada ocorrência de baixas concentrações de isótopos radioativos naturais de urânio, tório, potássio. A radiação artificial, também pode produzir efeitos semelhantes. Essa radiação pode realizar alterações no estado de oxidação dos íons metálicos presentes na estrutura do mineral, interagindo com as vacâncias e/ou elétrons extraídos dos orbitais, os quais são considerados "defeitos" na estrutura do cristal. Estes defeitos são denominados de "centros de cor".

Na maioria das vezes, a coloração está ligada a substituição do silício por íons de $\mathrm{Al}^{3+}, \mathrm{Fe}^{3+}, \mathrm{OH}^{-}$e $\mathrm{H}_{2} \mathrm{O}$. Essa substituição gera um desequilíbrio eletrônico devido a diferença entre suas valências. O restabelecimento do equilíbrio é feito por íons monovalentes, também conhecidos como "compensadores eletrônicos", tais como $\mathrm{Li}^{+}, \mathrm{Na}^{+}, \mathrm{K}^{+} \mathrm{e} \mathrm{H}^{+}$(Figura 6.4) (Rossman 1994).

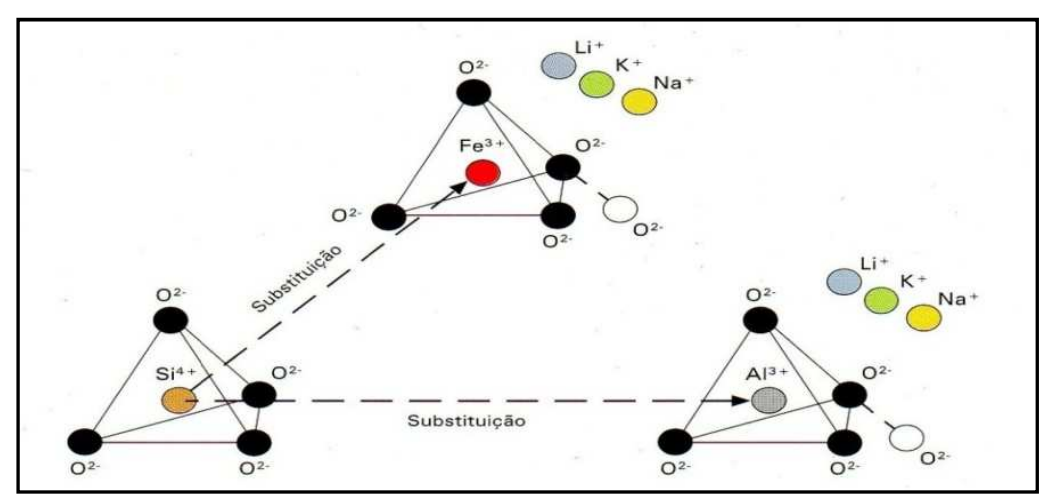

Figura 6.4: Principais Impurezas responsáveis pela coloração do Quartzo. Fonte Castaneda (2001).

O conteúdo de $\mathrm{Li}^{+}, \mathrm{Na}^{+}$, e K ${ }^{+}$é proporcional ao conteúdo de $\mathrm{Fe}+\mathrm{Al}$, enquanto que as quantidades de $\mathrm{H}^{+}$só podem ser obtidas, se houver $(\mathrm{OH})^{-}$ou água molecular na estrutura do mineral (Dennem, 1966). O teor de Fe presente no quartzo está na faixa de 10 até 350ppm, enquanto o teor de Al encontra-se entre 13 e 15000ppm (Smith in Steele 1984).

Segundo Rossman (1994), o $\mathrm{Na}$ e $\mathrm{K}$ encontram-se principalmente relacionados ás causas de cores do quartzo sintético, enquanto o Li e $\mathrm{H}$, juntamente 
com o $\mathrm{Fe} \mathrm{e} \mathrm{Al,} \mathrm{constituem} \mathrm{os} \mathrm{principais} \mathrm{responsáveis} \mathrm{pela} \mathrm{cor} \mathrm{das} \mathrm{variedades}$ naturais do quartzo, como ametista, citrino e quartzo fumê.

De acordo com Hurlbut (1993), a coloração é devido a formação de centros de cores, quando o quartzo é exposto a elevadas temperaturas, o que leva o elemento que doou um elétron, a tentar compensar a camada defasada, através do ganho de energia. A coloração é efeito da radiação, e o elemento bombardeado vai completar suas camadas com elétrons capturados através de energia luminosa ou calor (Figura $6.5 \mathrm{a}, \mathrm{b})$.

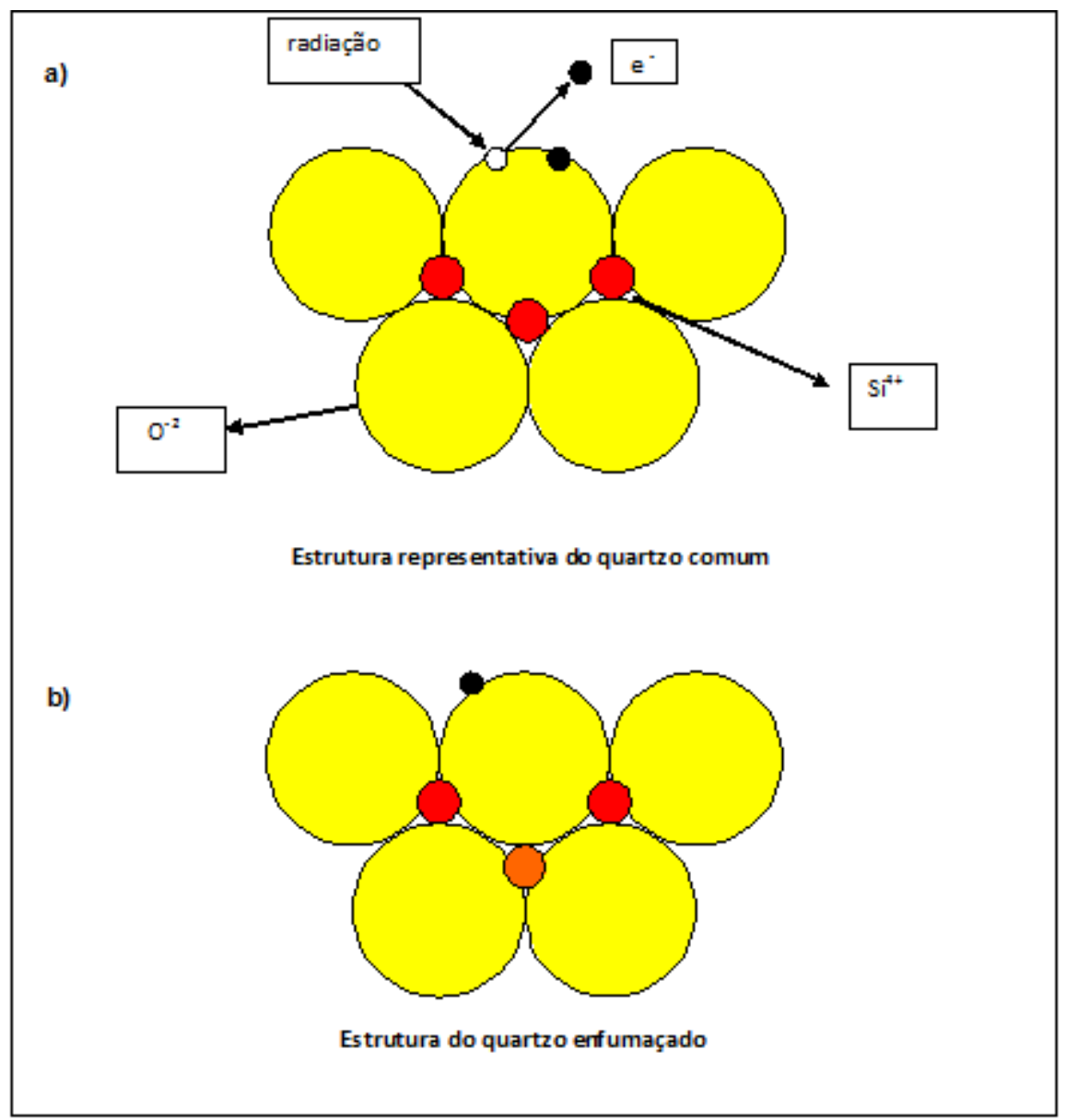

Figura 6.5 a, b: Desenho ilustrativo comparativo das estruturas dos quartzos hialino e enfumaçado. Fonte : Klein et. al, (1993). 


\section{c) Transferência de Carga}

O fenômeno de transferência de carga é o processo responsável pela aquisição da cor em diversas variedades coloridas do quartzo, como quartzo rosa, citrino proveniente do tratamento térmico da ametista, e ametista.

A transferência de carga consiste em uma movimentação de elétrons dentre os íons que constituem a estrutura do mineral, podendo dar origem a íons de valências diferentes. Esses elétrons podem se mover (ou saltar) de um átomo a outro, de inúmeras maneiras, as quais podem levar ao surgimento das cores no mineral (Rossman, 1994).

\section{d) Inclusões Minerais}

A presença de inclusões de outros minerais na estrutura cristalina do quartzo pode ser um fator determinante da sua coloração. As inclusões presentes estão diretamente relacionadas com a reflexão, difração, dispersão, interferência e espalhamento da luz no mineral.

O conteúdo de impurezas contido no cristal está diretamente relacionado ao ambiente de cristalização do quartzo, denotando a importância da correlação entre as variedades coloridas do quartzo e seus ambientes de formação.

\subsection{Cristal-de-rocha/ Quartzo Hialino}

O cristal de rocha ou quartzo hialino é o quartzo em seu estado ideal, sendo a variedade incolor e transparente do quartzo. O quartzo é incolor quando puro, mas pode assumir qualquer cor devido às inclusões de outros elementos e minerais em sua estrutura. $\mathrm{O}$ quartzo hialino é uma das principais variedades gemológicas do quartzo.

Ultimamente, os cristais de quartzo hialino tem sido alvo de muitos tratamentos, com o intuito de se obter gemas coradas a partir desses cristais. Através da irradiação gama, o quartzo hialino pode se tornar enfumaçado ou esverdeado (quartzo verde). Através de experimentos realizados com cristal-derocha, da região de Macaúbas/BA (Serra do Espinhaço), obteve-se como resultado do tratamento por irradiação, cristais de quartzo verde de boa qualidade gemológica. 
Devido as suas inclusões, o cristal-de-rocha pode mostrar alguns fenômenos, como asterismo, e iridescência (quartzo íris).

A palavra cristal deriva de Krystallos, do grego, que significa gelo. $\mathrm{Na}$ antiguidade, acreditava-se que o cristal-de-rocha era um gelo eterno.

As principais ocorrências de quartzo hialino conhecidas no mundo estão no Brasil (Minas Gerais, Bahia, Rio Grande do Sul), República de Malgaxe (Madagascar), Estados Unidos (Arkansas; Nova York), Europa (Alpes), e Japão.
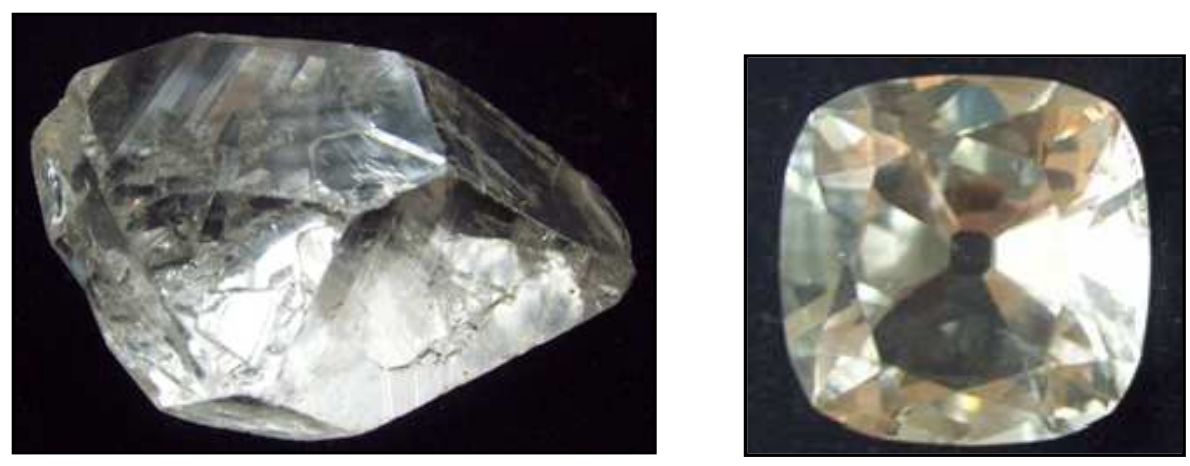

Fotos 6.1 e 6.2: cristais de quartzo hialino de qualidade gemológica

\subsection{Ametista}

Ametista é tida como a variedade púrpura a violeta do quartzo a (Trigonal, de baixa temperatura), cuja cor se desenvolve apenas na presença de íons de Fe. É uma das variedades de quartzo mais apreciada no mercado de gemas.

A cor da ametista está associada a uma transferência de carga entre $\mathrm{Fe}^{3+} \mathrm{e}$ $\mathrm{O}^{2-}$, o que leva a formação do íon (incomum) $\mathrm{Fe}^{4+}$ (oxidação $\mathrm{Fe}^{3+} \rightarrow \mathrm{Fe}^{4+}$ ), íon este, que segundo Lehmann (1976), é o agente responsável pela cor da ametista. A equação abaixo explica o processo de interação entre os íons, e a formação do íon $\mathrm{Fe}^{4+}$ (Rossman 1994).

$\left[\mathrm{Fe}^{3+}+\mathrm{O}_{4} \ldots \mathrm{X}\right]+\left[\mathrm{Fe}^{3+}+\mathrm{O}_{6}\right] \rightarrow\left[\mathrm{Fe}^{4+}+\mathrm{O}_{4} \ldots \mathrm{X}\right]+\left[\mathrm{Fe}^{2+}+\mathrm{O}_{6}\right]$, onde "X" são íons compensadores de carga.

De acordo com estudos realizados por Berthelot (1906), descobriu-se que a cor da ametista está associada à radiação ionizante. A irradiação natural ou artificial dá início ao mecanismo de transferência de carga, e consequentemente ao 
surgimento da cor violeta da ametista (Cox, 1977). A cor da ametista pode ser facilmente destruída pelo calor, mas pode ser restaurada pela ação da radiação inonizante, se o calor não for excessivo.

Segundo Cohen (1984), a intensidade da banda de absorção da ametista a 545nm tem características de transferência de carga, fenômeno este, responsável pelos tons mais fortes nas cores do mineral. A cor violeta intensa de alguns cristais de ametista, como as de Pau D' Arco (PA), e as de Brejinho das Ametistas (BA), podem ser explicadas por este fenômeno.

Favacho-Silva (2000), admite em seu trabalho, que a água molecular e/ou hidroxila, contidas na estrutura da ametista, também contribuem para a sua coloração.

A cor na ametista nem sempre é uniforme, podendo apresentar alternância de faixas ou manchas claras e escuras no interior do cristal, as quais encontram-se normalmente concentradas na face romboédrica principal, $r=\{1011\}$, ou em forma de finas bandas que se paralelizam a face " $r$ " ou a face $z=\{0111\}$. A geminação polissintética é comumente observada em cristais de ametista.

Acreditava-se, por volta dos anos 60, que a cor da ametista era causada por $\mathrm{Au}$, Ti ou Mn. Este último elemento foi citado como agente responsável pela cor, devido a cor da ametista ser muito semelhante a cor do $\mathrm{KMnO}_{4}$ (permanganato de potássio) (Berthelot 1906).

A ametista normalmente apresenta um pleocroísmo muito fraco, violeta a violeta-acinzentado, e uma fluorescência quase ausente, em tom esverdeado. As inclusões mais comumente encontradas em ametista são hematita e goethita em formas de agulhas e/ou palhetas. 


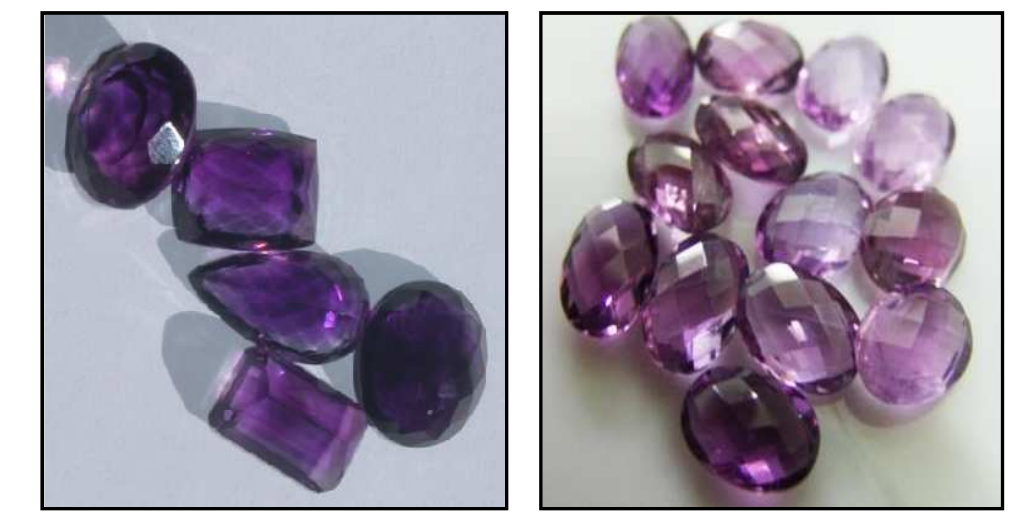

Fotos 6.3 e 6.4: Cristais de ametista de qualidade gemológica, de diversas tonalidades.

Quando submetida a tratamento térmico, a ametista pode apresentar tons nas cores amarela ou verde, de acordo com os íons presentes em sua estrutura (Figura 6.6).

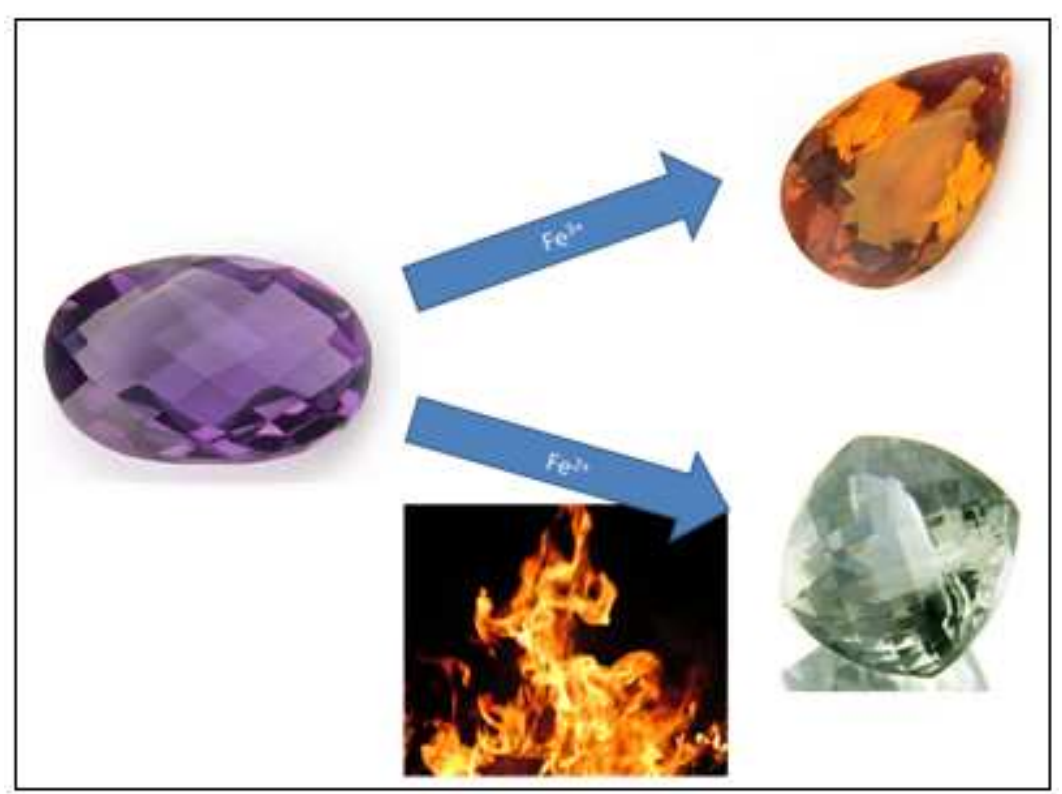

Figura 6.6: Variedades coloridas da ametista obtidas através de tratamento térmico. Citrino (amarelo) e Prasiolita (verde).

A origem de seu nome vem do grego, "amethuskein", que significa "desintoxicar", de acordo com a antiga crença de que esta pedra protegia seu dono da embriaguez, do sono, de venenos e até mesmo de gafanhotos.

As principais ocorrências conhecidas de ametista no mundo são Brasil (Rio Grande do Sul, Bahia, Minas Gerais, Pará Goiás), República de Malgaxe (Madagascar), Zâmbia, Uruguai, Birmânia (Myanmar), Índia, Canadá, México, Namíbia, Rússia, Sri Lanka, Estados Unidos, Paraguai e Austrália. 


\subsection{Citrino}

O citrino é tido como a variedade amarelo alaranjado do quartzo, e pode ser dividido em dois grupos principais, sendo eles; a) ametista tratada por aquecimento térmico, grupo que compreende a grande maioria do citrino comercializado; b) citrino de ocorrência natural.

\section{a) Citrino Termicamente Tratado}

O citrino desta variedade constitui um mineral de coloração variando de amarelo claro a avermelhado, ou ainda, amarelo-amarronzado a pardo-dourado. $\mathrm{O}$ citrino tratado por aquecimento não apresenta pleocroísmo.

O tratamento térmico da ametista para a produção do citrino consiste no aquecimento da ametista em uma faixa de temperatura entre 450 a 500 , a qual resulta em amostras de citrino de coloração amarelo claro. Para a obtenção de amostras de coloração amarelo escuro, pardo-avermelhado/dourado, tendendo a amarronzado, o aquecimento deve ser realizado a temperaturas na faixa de 550 a $600^{\circ} \mathrm{C}$.

O responsável pela cor da "ametista queimada ou falso citrino", é o íon $\mathrm{Fe}^{3+}$, no qual o íon $\mathrm{Fe}^{4+}$, responsável pela cor na ametista, sofre redução pelo aquecimento, passando para o íon $\mathrm{Fe}^{3+}$.
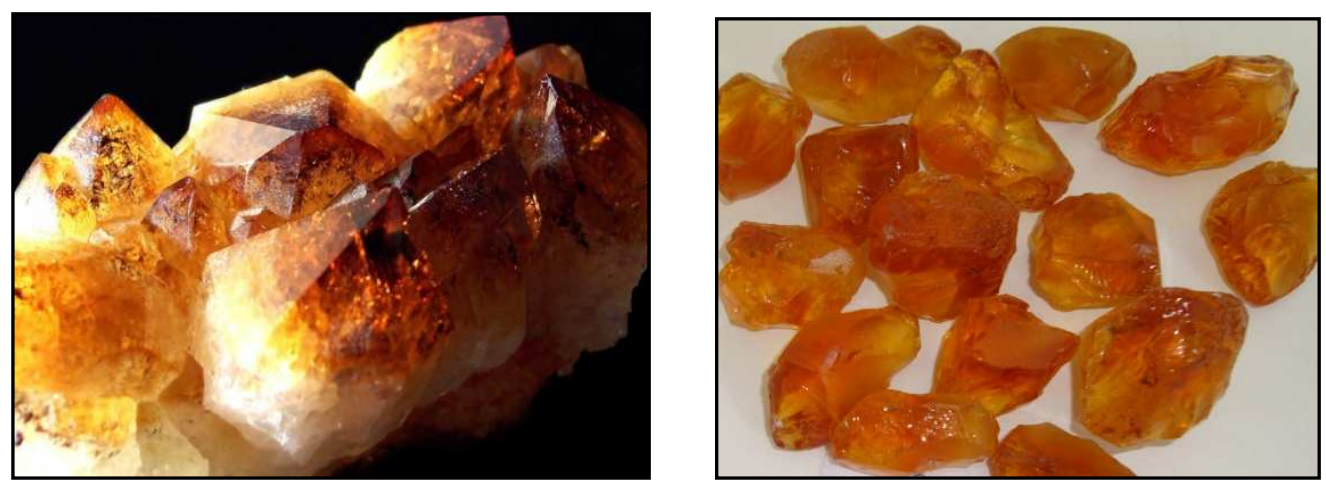

Fotos 6.5 e 6.6: Cristais de citrino provenientes de ametista termicamente tratada 


\section{b) Citrino de Ocorrência Natural}

Cristais de citrino de ocorrência natural constituem minerais de coloração variando de cinzento, cinza amarelado, cinza esverdeado a amarelo pálido amarronzado. Este tipo de citrino apresenta um pleocroísmo muito fraco (amareloamarelo claro).

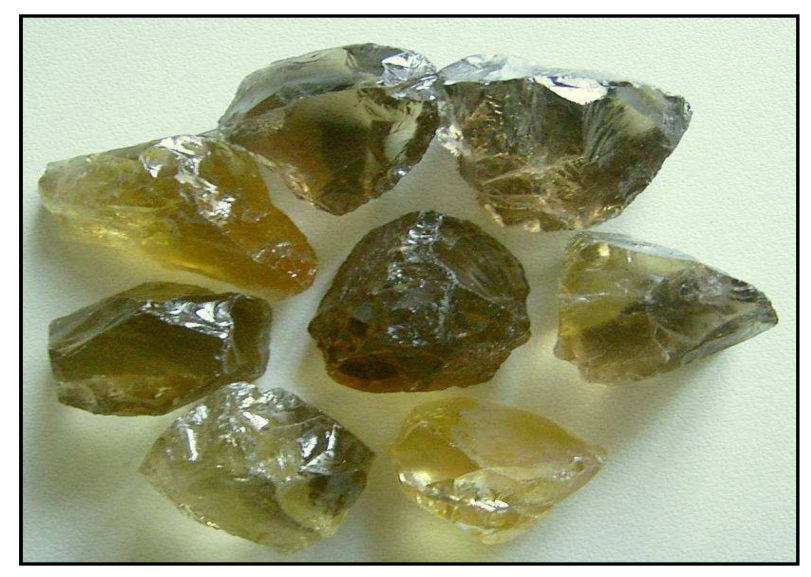

Foto 6.7: Cristais de citrino de ocorrência natural.

Em 1965, Barry \& Moore indicaram o íon $\mathrm{Fe}^{3+}$ substitucional, como a causa mais provável da cor no citrino natural, com base em padrões de EPR. E em 1986, Aines \& Rossman indicaram a presença do hidrogênio em certas zonas do citrino sob a forma de molécula de água, mas o papel da água molecular na causa de cor do citrino ainda é pouco conhecido. Segundo Maschmeyer \& Lehmann (1983), um defeito na estrutura do quartzo, conhecido como centro de cor é a principal causa da cor no citrino natural.

A causa de cor do "citrino natural" é compreendida hoje pela presença do íon $\mathrm{Al}^{3+}$ na estrutura do quartzo, na qual ele encontra-se substituindo o íon $\mathrm{Si}^{4+}$, causando um desequilíbrio eletrônico, o qual é compensado pela entrada de íons compensadores de carga, como cátions de $\mathrm{H}^{+}$ou Li+ (Schmetzer 1989).

Com base no estudo do espectro de ressonância paramagnética eletrônica de amostras de citrino natural, elaborado por Maschmeyer et. al. (1980), acredita-se que a cor do citrino tem sua origem por meio da irradiação natural. Neste trabalho, os autores descreveram a existência de dois centros de cor no citrino. Mais tarde, Maschmeyer \& Lehmann (1983), descreveram sete centros de cor em cristais de citrino, os quais são originados pela irradiação. 
Cristais de citrino com colorações tendendo ao fumê adquirem cores mais amareladas (Schmetzer, 1989), se submetidos ao tratamento térmico, a temperaturas na faixa de 300 a $400{ }^{\circ} \mathrm{C}$.
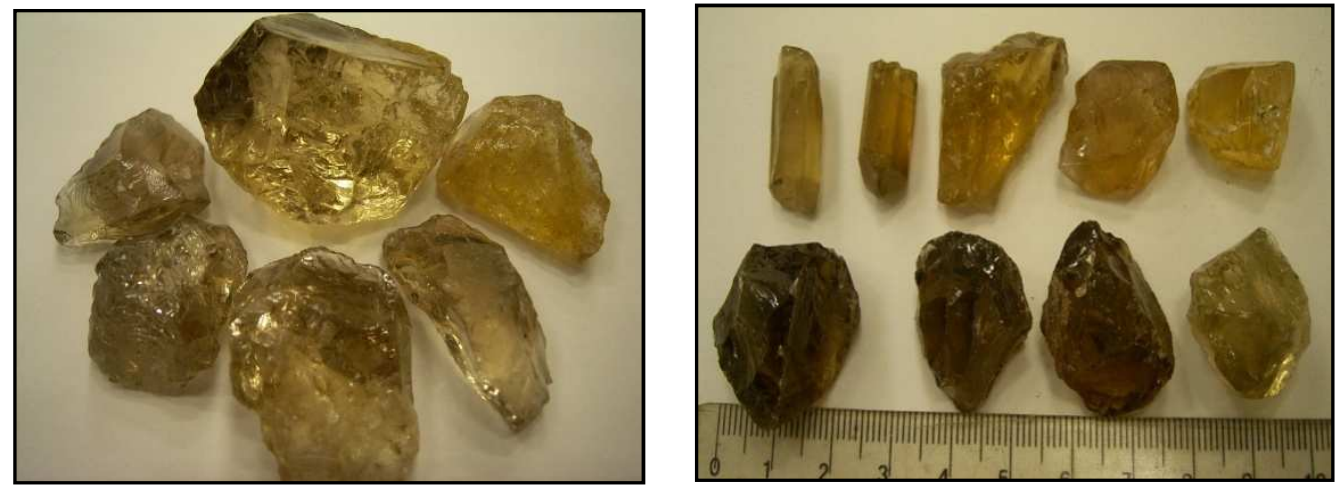

Fotos 6.8 e 6.9: Cristais de citrino natural submetidos ao tratamento térmico para melhoramento de sua cor.

A Irradiação também pode ser citada como um importante mecanismo para a obtenção de tons amarelo alaranjado no citrino, desde que o quartzo possa receber doses maiores de radiação a partir do decaimento do isótopo instável $\mathrm{K}_{40}, \mathrm{U}$, Th, e seus subprodutos.

A origem do seu nome vem do latim "citrus", devido a sua cor amarelada. O citrino também é conhecido e comercializado com o nome de Topázio Rio Grande, Topázio Bahia, Topázio da Espanha, Topázio Madeira, Topázio Ouro, e Topázio de Palmeira.

O citrinos natural é raro. As principais ocorrências mundiais conhecidas deste material encontram-se no Brasil (Minas Gerais, Bahia, Goiás, Espírito Santo), República de Malgaxe (Madagascar), Argentina, Birmânia (Myanmar), Namíbia, Rússia, Escócia, Espanha, Estados Unidos (Colorado), e França.

\subsection{QuartzoFumê/ Morion}

O quartzo fumê é a variedade do quartzo de coloração parda, acinzentada, enfumaçada, podendo chegar a negra, a qual é conhecida como quartzo "morion". 
Cristais de quartzo fumê normalmente apresentam um pleocroísmo definido (pardo - pardo-avermelhado). É também chamado de "Pedra de Cairngorm", nome do local na Escócia, onde foi encontrado/extraído pela primeira vez.
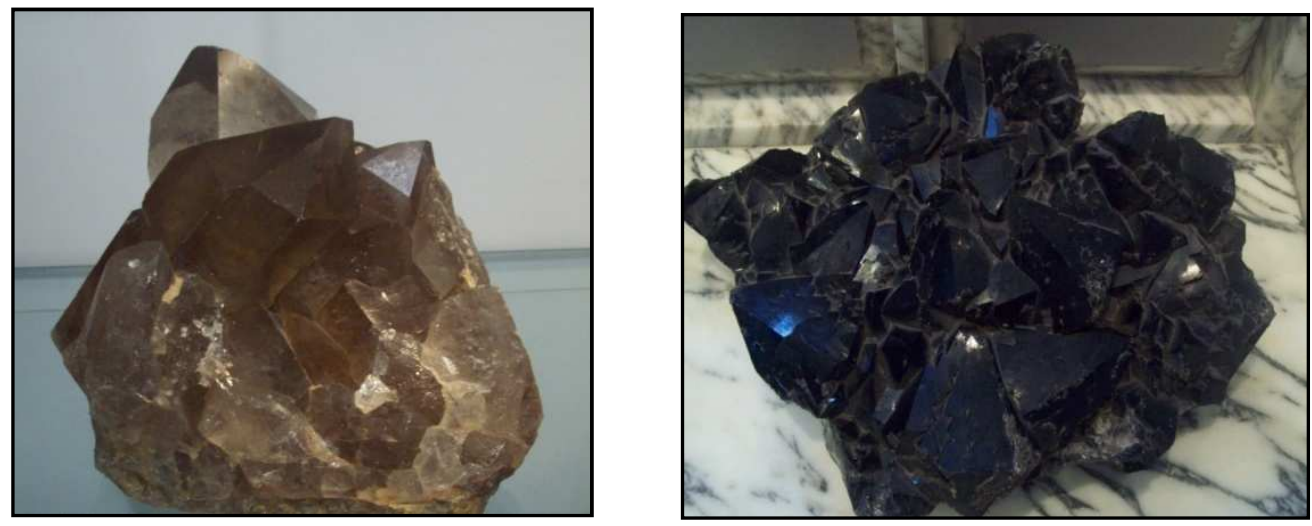

Fotos 6.10 e 6.11: Cristais de quartzo fumê e morion, respectivamente.

A coloração acinzentada é devido a formação de um defeito na estrutura, conhecido como centro de cor, no qual o íon de $\mathrm{Si}^{4+}$ é substituído por um íon de $\mathrm{Al}^{3+}$. Essa substituição causa um desequilíbrio eletrônico, o qual é compensado por um cátion de $\mathrm{H}^{+}, \mathrm{Na}^{+}$ou de $\mathrm{Li}^{+}$, para que se mantenha a neutralidade elétrica. $\mathrm{A}$ coloração é efeito da radiação natural em quartzo com impurezas de $\mathrm{Al}$ e $\mathrm{Li}$, o íon irradiado vai completar suas camadas com elétrons capturados através de energia luminosa ou do calor (Hurlburt, 1993). O modelo abaixo, desenvolvido por O'Brien e Pryce (1955), representa detalhadamente o centro de cor no quartzo fumê. Este modelo é baseado em ressonância paramagnética eletrônica de quartzo fumê irradiado com raio-X.

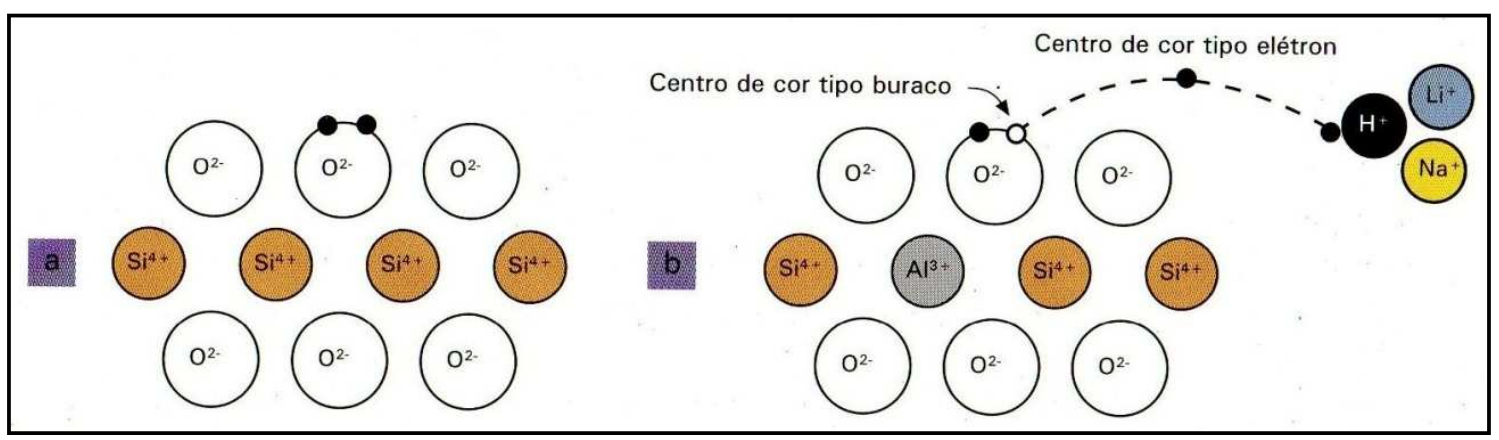

Figura 6.7: Formação do centro de cor no quartzo: a) Molécula de $\mathrm{SiO}_{2}$ (quartzo incolor) antes da irradiação, b)Depois da irradiação, nos locais onde o $\mathrm{Si}^{4+}$ é substituído pelo $\mathrm{Al}^{3+}$. Existe um desequilíbrio eletrônico (falta de uma carga positiva) em que o restabelecimento ocorre com a retirada de um elétron (Fonte: Nassau, 1984). 
De acordo com Guzzo et. al. (1997), o centro de cor Al-Li é responsável pela coloração do quartzo fumê em ambientes pegmatíticos, enquanto que em ambientes hidrotermais, o centro de cor responsável pela coloração é o Al-OH. Mackey (1963) determinou que a partir de padrões de espectros de ressonância paramagnética eletrônica em cristais de quartzo fumê irradiados, nos quais um cátion monovalente, situado nas redondezas do íon $\mathrm{Al}^{3+}$, encontrar-se-ia associado com $\circ \mathrm{Al}$ substitucional, constituindo assim, um centro de cor do tipo $\left[A \mid \mathrm{O}_{4} / \mathrm{M}\right]^{0}$, onde $\mathrm{M}=\mathrm{H}^{+}$, $\mathrm{Li}^{+}$ou $\mathrm{Na}^{+}$.

O quartzo fumê pode perder com facilidade sua cor a temperaturas de 140 a $400^{\circ} \mathrm{C}$. Segundo Favacho-Silva (2000), quanto a estabilidade da cor do quartzo fumê, pode-se dizer que as amostras, provenientes da Serra do Espinhaço (hidrotermal) tem maior estabilidade do que as provenientes da Província Pegmatítica Oriental Brasileira, o que indica que a presença de lítio diminui a estabilidade da cor no quartzo fumê.

Através da combinação de irradiação gama e tratamento térmico, alguns cristais de quartzo fumê podem se tornar laranja-amarronzados (Gutter et. al. 2009).

As inclusões mais comumente encontradas no quartzo fumê são agulhas de rutilo, as quais podem causar o fenômeno do asterismo (Foto 6.12).

Dentre as principais ocorrências de quartzo fumê conhecidas no mundo, tem destaque para as do Brasil, República de Malgaxe (Madagascar), Rússia, Escócia, Suíça, Ucrânia e Estados Unidos.

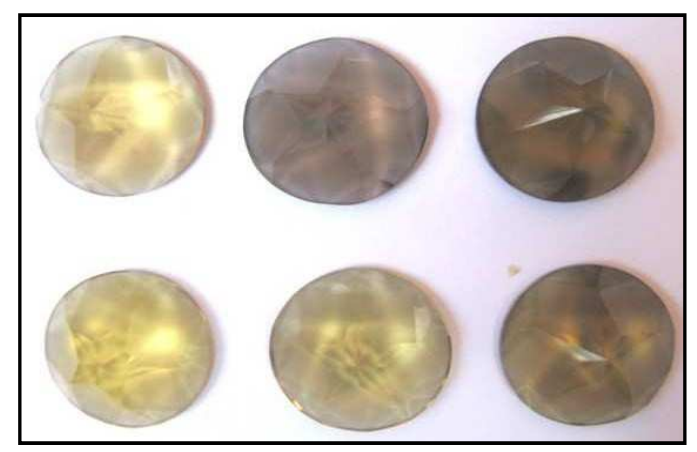

Foto 6.12: Cristais de quartzo fumê apresentando asterismo. 


\subsection{Quartzo Rosa}

O quartzo rosa é a variedade de coloração rosada do quartzo, e pode ser dividido em dois grupos principais de acordo com os elementos responsáveis pela sua cor, e a sua aparência. Ambos são fundamentalmente diferentes quanto a origem de sua coloração, sua foto estabilidade e seu espectro de absorção, sendo eles; a) aparência maciça e intercrescimento de rutilo e dumortierita b) cristais euédricos, bem formados, com presença de impurezas de $\mathrm{P}$ ou Fe.

\section{a) Aparência Maciça, e Intercrescimento de Rutilo e Dumortierita}

Constituem minerais de coloração rosa intenso a rosa pálido. Os cristais são normalmente translúcidos e sem brilho visível, de estrutura maciça, de aspecto nevoado, e apresentam com freqüência, grande quantidade de fissuras. Essa variedade desbota quando exposto a luz, já que sua cor é estável até por volta de $575^{\circ}$.

Acredita-se que o agente responsável pela coloração dessa variedade do quartzo rosa, é o intercrescimento do quartzo com cristais de dumortierita (Applin \& Hicks, 1987) ou a presença de agulhas de rutilo (Vultée, 1955 a, b; Vultée \& Lietz,1956).

É freqüente nesses cristais de quartzo rosa, a presença de pequenas inclusões de agulhas de rutilo, as quais causam o fenômeno do asterismo (normalmente em formato de estrela de seis pontas), bem visualizado quando lapidado em forma de cabochão.

O quartzo rosa maciço ocorre associado a cristais de feldspato, normalmente em pegmatitos, com ou sem outros tipos de gemas agregadas.

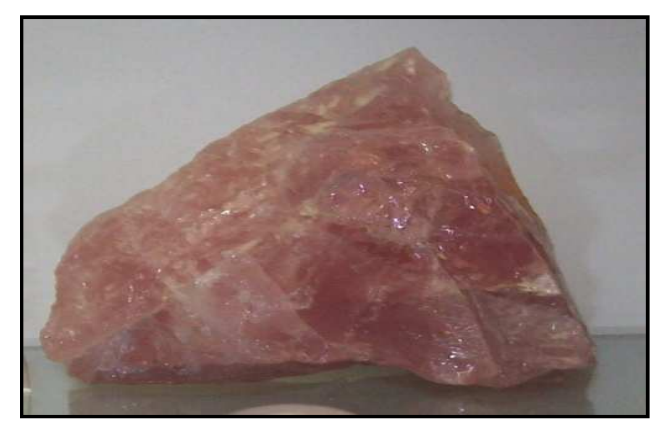

Foto 6.13: Cristal de quartzo rosa de aparência maciça. 


\section{b) Cristais Euédricos, com Presença de Impurezas de P ou Fe.}

Constituem minerais de coloração vermelho-rosa a róseo intenso. Os cristais são, na maioria das vezes, translúcidos e euédricos bem definidos. Se submetidos a irradiação gama, sua coloração se intensifica, tendendo ao vermelho.

A questão do agente corante dessa variedade do quartzo rosa é algo muito discutido desde o início do século $\mathrm{XX}$, e vem sendo discutido até hoje por pesquisadores renomados e especialistas da área. Por volta de 1924, Holden acreditava que a coloração era proveniente da presença do íon $\mathrm{Mn}^{3+}$ na estrutura do cristal. Em 1962, análises químicas de amostras de quartzo rosa, realizada por Masgutov, apresentaram resultados que comprovaram a ausência de $\mathrm{Mn}$ na composição do mineral $(0.000 x$ \%MnO). Lehmann (1969) propôs que a coloração do quartzo rosa era decorrente da substituição do íon de $\mathrm{Si}^{4+}$ pelo íon de $\mathrm{P}^{5+}$. Segundo Smith (1978), a coloração é razão da substituição do íon de $\mathrm{Fe}^{2+}$ (intersticial) pelo íon de $\mathrm{Si}^{4+}$ (substitucional). E de acordo com Cassedanne \& Roditi (1991), sua cor está ligada a existência de um centro de cor, tendo o fósforo como elemento principal, devido a cor do quartzo rosa possuir baixa estabilidade, e desaparecer a aproximadamente $200^{\circ} \mathrm{C}$.
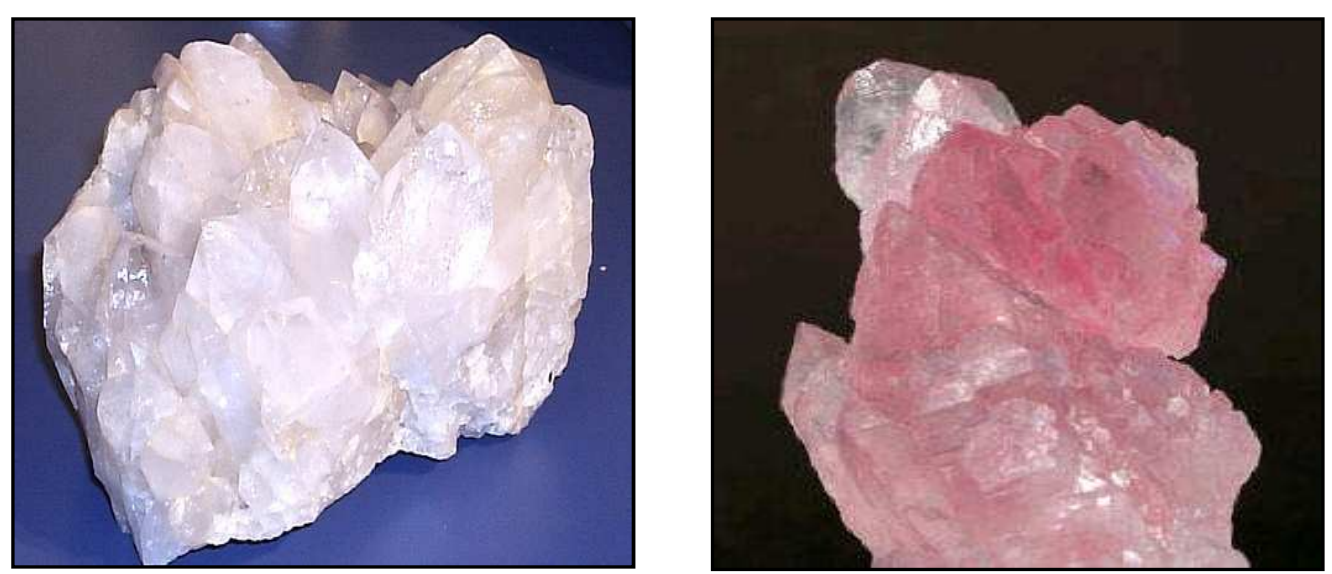

Fotos 6.14 e 6.15: Cristais de quartzo rosa natural e submetido a irradiação gama, respectivamente

Dentre as ocorrências mundiais conhecidas de quartzo rosa tem-se destaque para as do Brasil, República de Malgaxe (Madagascar), Índia, Moçambique, Namíbia, Sri Lanka e Estados Unidos. 


\subsection{Green Gold}

Green Gold é tida como uma variedade do quartzo, produzido em laboratório, de coloração verde-oliva a verde amarelado.

Esta espécie de quartzo pode ser obtida através de dois processos; $1^{\circ}$ ) através da irradiação gama sobre quartzo hialino até ele tornar-se fumê, seguido por tratamento térmico à temperaturas na faixa de 140 a $280^{\circ} \mathrm{C} ; 2^{\circ}$ ) tratamento térmico sobre o quartzo fumê de ocorrência natural, a baixas temperaturas. Essa coloração incomum do quartzo tem sido obtida através de cristais de quartzo hialino provenientes da região de São José da Safira - MG (Guttler, 2009).

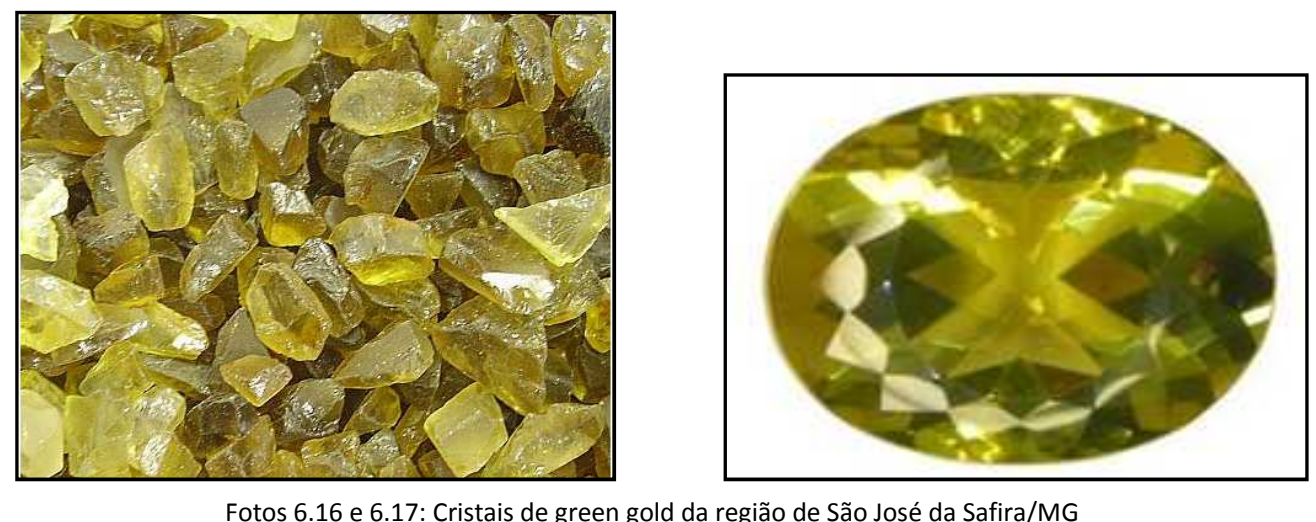

A cor desta variedade de quartzo é causada pela substituição do íon de $\mathrm{Si}^{4+}$ pelo íon de $\mathrm{Al}^{3+}$, causando um desequilíbrio eletrônico, o qual é compensado pela entrada de um cátion de $\mathrm{H}^{+}$ou de $\mathrm{Li}^{+}$na estrutura.

Cristais de Quartzo Green Gold apresentam alto teor de $\mathrm{H}_{2} \mathrm{O}, \mathrm{Al}^{3+}, \mathrm{H}^{+}, \mathrm{Li}^{+}$; e pouquíssimo Fe na sua composição (Favacho-Silva, 2000).

Lehmann (1971) reconheceu, primeiramente, que o quartzo verde-amarelado poderia ser obtido a partir da irradiação de quartzo natural com alto teor de Al e $\mathrm{H}$. De acordo com Schmetzer (1989), variedades de quartzo verde-amarelados podem ser consideradas como citrino. 


\subsection{Prasiolita/ Ametista Verde}

A prasiolita, também é conhecida vulgarmente como "ametista verde", é a variedade do quartzo produzida em laboratório, de coloração verde intenso a verde acinzentado, a partir de cristais de ametista de origem hidrotermal (Guttler, 2009).

Essa variedade do quartzo é produzida desde 1950, através do tratamento térmico de cristais de ametista à temperaturas na faixa de 400 a $500^{\circ} \mathrm{C}$. A prasiolita só é obtida com ametista rica em íons de $\mathrm{Fe}^{3+}$ e $\mathrm{Al}^{3+}$, e muito pobre em $\mathrm{H}_{2} \mathrm{O}$. A redução do Ferro $\left(\mathrm{Fe}^{3+} \rightarrow \mathrm{Fe}^{2+}\right.$ ) é o causador da cor (Rossman, 1994). Atualmente, esta variedade de quartzo vem sendo produzida a partir de cristais de ametista provenientes da mina de Montezuma-MG.

A cor da prasiolita é muito estável, podendo suportar temperaturas superiores a $600^{\circ}$, sua fotoestabilidade é muito superior a do quartzo verde.
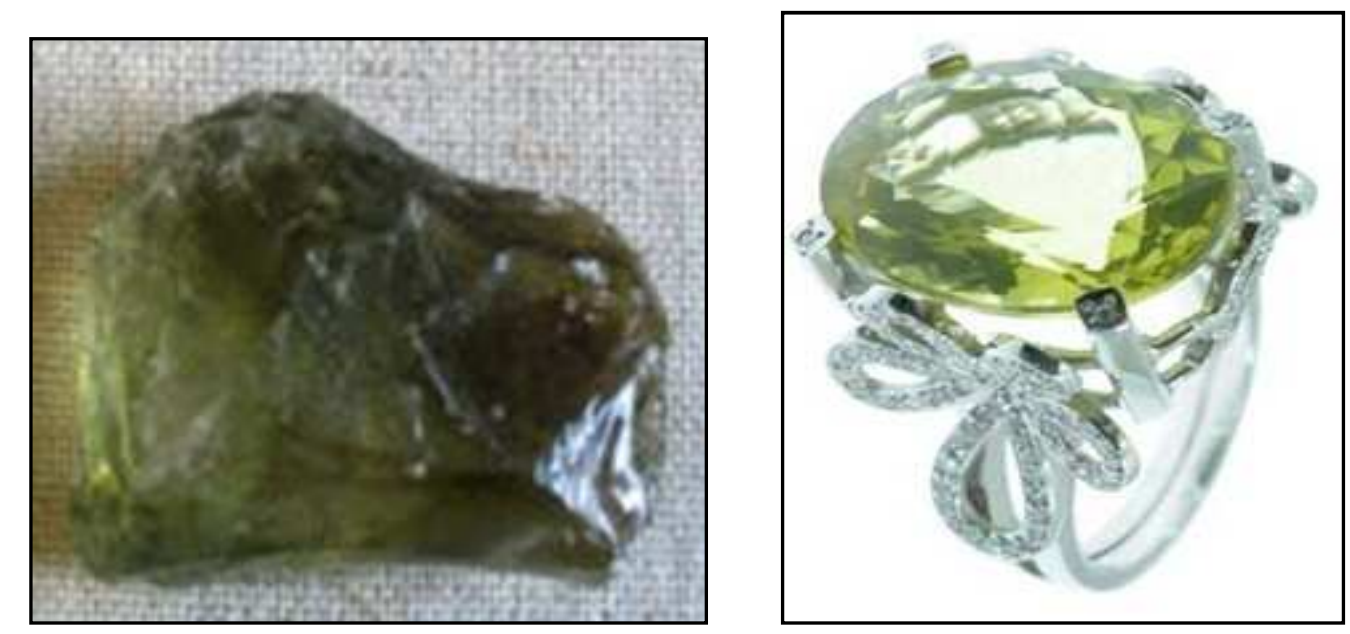

Fotos 6.18 e 6.19: cristais de prsiolita nas formas bruta e lapidada, respectivamente

\subsection{Quartzo Verde}

O quartzo verde é a variedade verde claro, verde acinzentado ou levemente esverdeado do quartzo produzido em laboratório, através da irradiação gama no quartzo hialino.

Esses cristais apresentam alto teor de $\mathrm{H}_{2} \mathrm{O}$ e $\mathrm{OH}$, defeitos na estrutura (centros de cor) e pouquíssimo teor de Fe em sua composição. O principal causador da coloração do quartzo verde é o alto teor de água e/ou hidroxila existente na estrutura do mineral (Guttler, 2008). 
A coloração esverdeada do quartzo desbota facilmente sob forte luz ultravioleta ou sob temperaturas na faixa de 150 a $200^{\circ} \mathrm{C}$. Atualmente, esta variedade de quartzo vem sendo produzida a partir de cristais de quartzo hialino, de depósitos hidrotermais provenientes do Rio Grande do Sul, Paraná, Minas Gerais, e Bahia (Macaúbas).
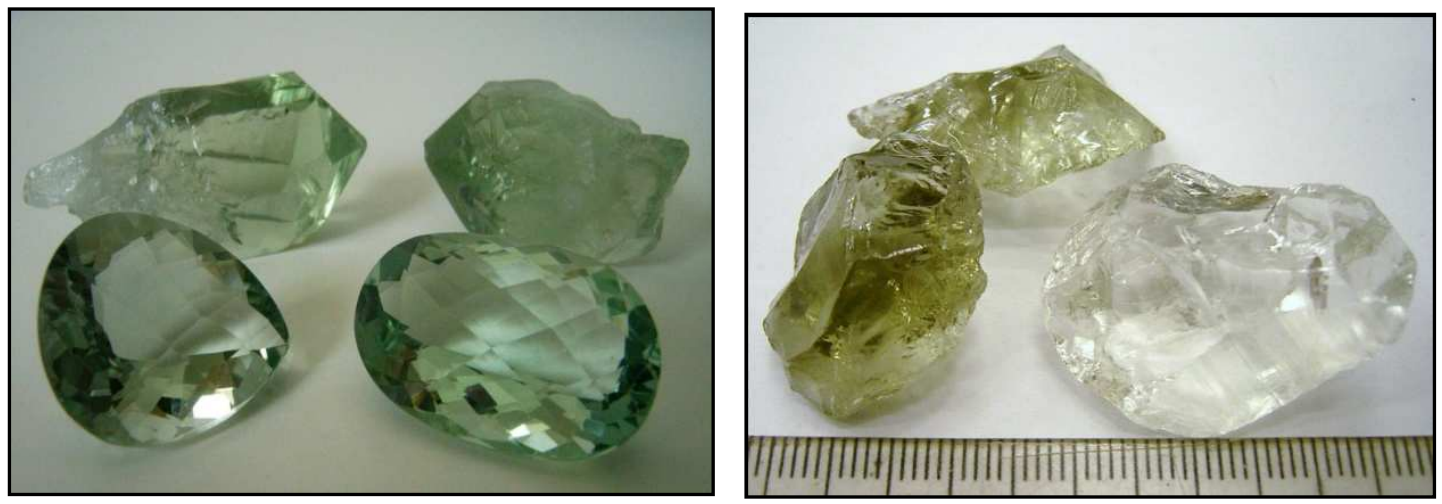

Fotos 6.20 e 6.21: Cristais de quartzo verde produzidos através de irradiação gama em quartzo hialino, da região de Macaúbas/BA.

A prasiolita e o quartzo verde, a olho nu são praticamente idênticos, mas eles podem ser diferenciados com a ajuda do filtro Chelsea. Todos os cristais de "quartzo verde" derivado da irradiação do quartzo incolor mostram-se vermelhos ou avermelhados sob luz incandescente se observados através do filtro Chelsea, enquanto a "prasiolita", derivada da queima da ametista, permanece esverdeada (Guttler, 2008).

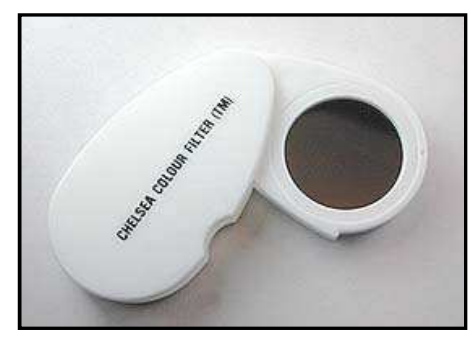

Foto 6.22: Filtro Chelsea.

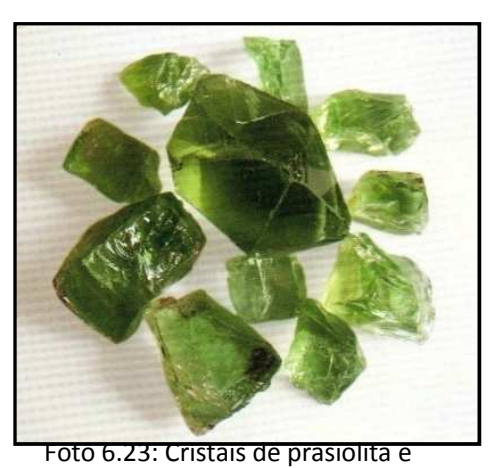

quartzo verde vistos a olho nu.

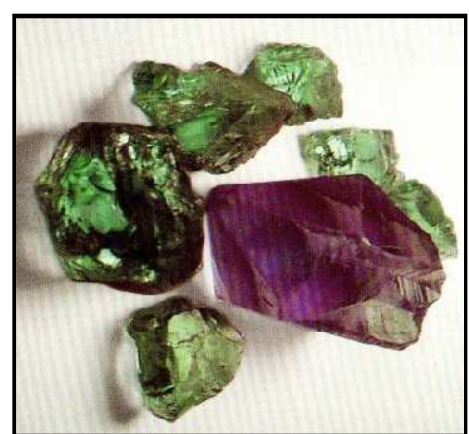

Foto 6.24: Cristais de prasiolita e quartzo verde, vistos através do filtro Chelsea. 


\subsection{Quartzo Azul}

O quartzo azul é a variedade de coloração azulada a azul profundo do quartzo, a qual pode ser dividida em dois grupos principais, sendo eles; a) quartzo azul produzido através de irradiação gama; b) quartzo azul de ocorrência natural.

\section{a) Produzidos por Irradiação Gama}

Esta variedade do quartzo azul constitui minerais de coloração azul arroxeado, acinzentado a azul profundo.

É produzido através da irradiação gama ou do tratamento térmico a temperaturas em torno de 350 a $450^{\circ} \mathrm{C}$ da ametista ( $p$ rasiolita), seguido de uma segunda irradiação gama da mesma amostra (Guttler \& Kohigashi, 2006).

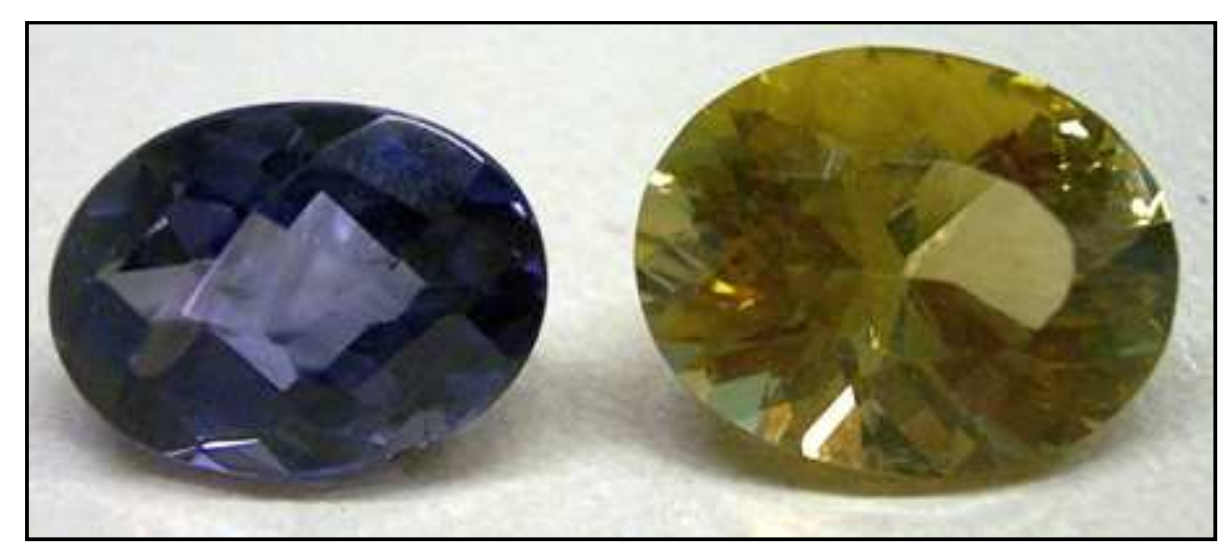

Foto 6.25: Cristais de quartzo azul e prasiolita, respectivamente.

\section{b) Ocorrência Natural}

Constituem minerais de coloração azul esbranquiçado a azul profundo, composto por agregados de quartzo de granulação grossa.

A cor azul, geralmente turva, é causada por grande quantidade de inclusões de agulhas de rutilo, ilmenita e crocidolita, agulhas de turmalina azul, dumortierita ou grande quantidade de minúsculas inclusões fluidas. A cor é efeito da dispersão da luz incidente nas inclusões. 

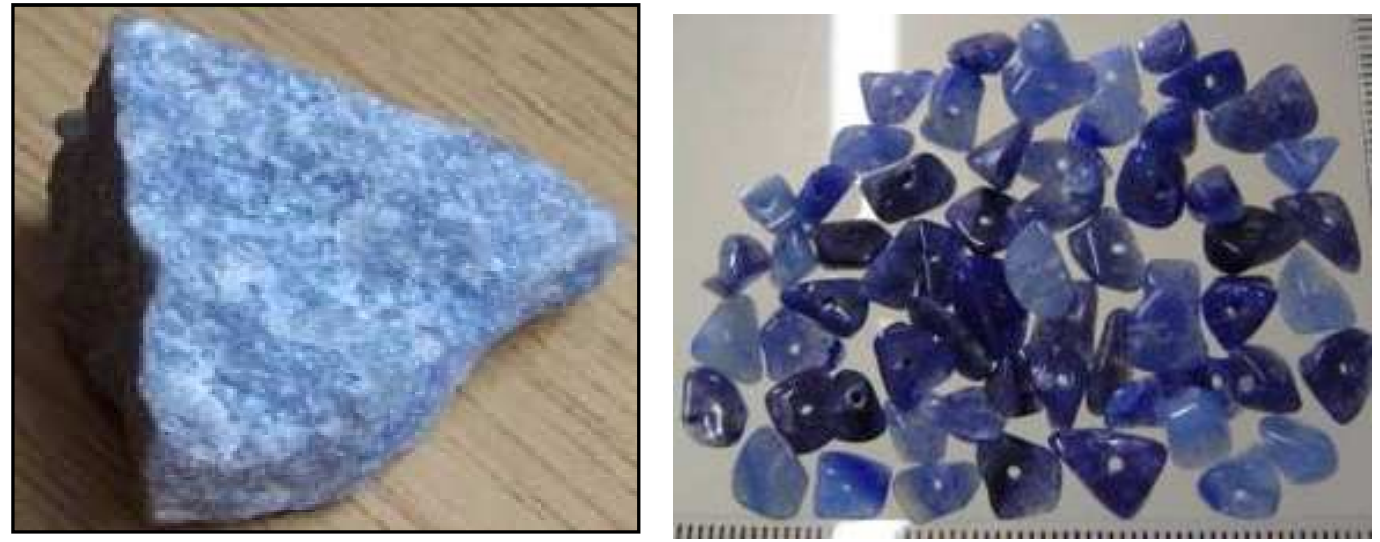

Fotos 6.26 e 6.27: Cristais de quartzo azul de ocorrência natural.

Dentre as principais ocorrências mundiais de quartzo azul destacam-se as do Brasil, Escandinávia, Áustria (Salzburg), África do Sul, Espanha e Estados Unidos (Virgínea).

\subsection{Quartzo Leitoso}

O quartzo leitoso é a variedade de coloração branca leitosa do quartzo, a qual é causada pela presença de minúsculas inclusões fluidas, as quais dão ao quartzo um aspecto translúcido. Em alguns casos, amostras apresentam brilho gorduroso, e são sempre translúcidos.

Essa é a variedade colorida mais comum do quartzo, a qual pode ser encontrada associada a qualquer outra variedade do quartzo e de diversos minerais, em ambientes pegmatíticos, ou em veios hidrotermais.

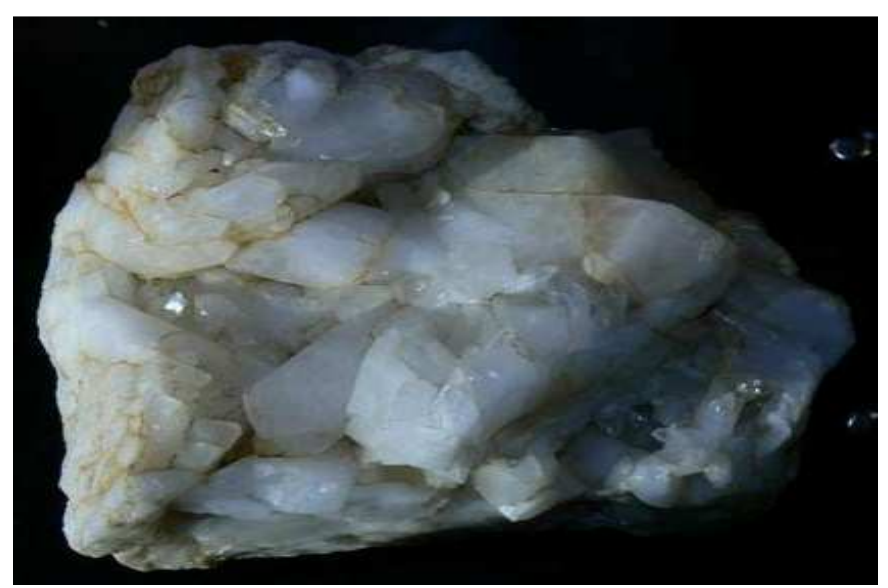

Foto 6.28: Cristal de quartzo Leitoso 


\subsection{Quartzo Hematóide}

O quartzo hematóide é a variedade do quartzo de coloração vermelho, vermelho-alaranjado a amarronzado. Sua cor é devido a presença de pequenas e variáveis quantidades de inclusões de goethita e/ou hematita no cristal. Ele normalmente ocorre associado a depósitos hidrotermais de ametista, como pode ser observado na mina Grota do Coxo, na região de Jacobina/BA.
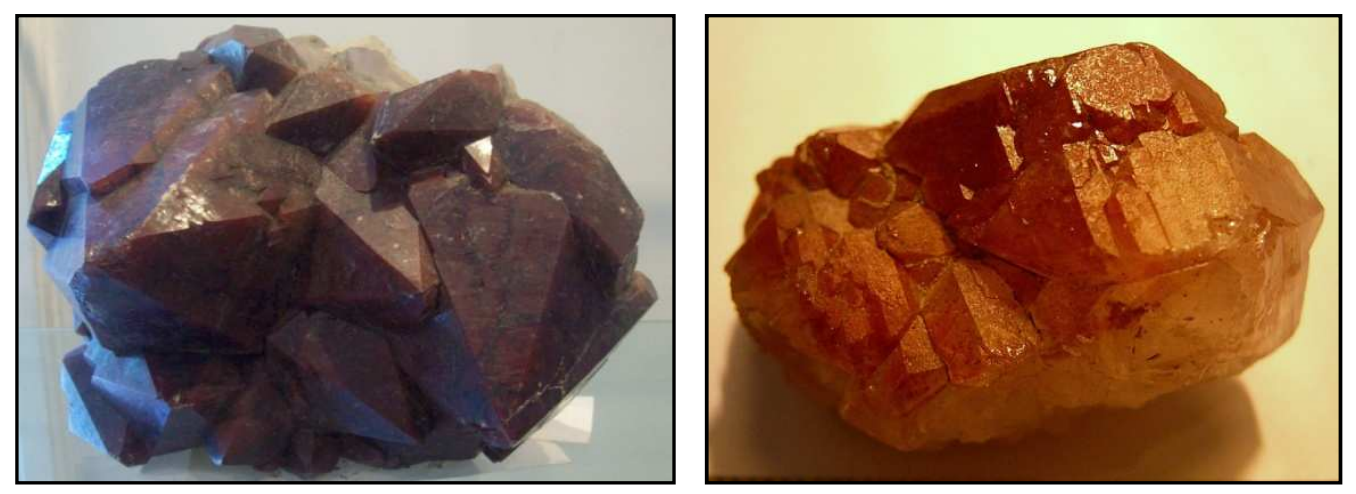

Foto 6.29 e 6.30: Cristais de hematóide da mina Grota do Coxo, Jacobina/BA.

\subsection{Influência do Ambiente Geológico}

\subsubsection{Introdução}

De acordo com a literatura, estudos e observações de campo, pode-se dizer que as variedades coloridas do quartzo parecem estar diretamente relacionadas com um determinado tipo de ambiente geológico de formação.

$\mathrm{Na}$ Bahia, a ametista predominantemente ocorre relacionada a depósitos hidrotermais, enquanto que o quartzo hialino pode aparecer tanto relacionado com depósitos hidrotermais, quanto com depósitos pegmatíticos. O quartzo hialino, se submetido a irradiação gama em laboratório, pode fornecer dados importantes referentes o seu ambiente de formação, de acordo com a sua coloração adquirida com a radiação.

Pode-se dizer que é indispensável para uma melhor compreensão das causas de cor do quartzo natural, bem como daqueles coloridos através de tratamentos térmicos e irradiação, a correlação entre a tipologia dos depósitos de quartzo e suas variedades coloridas. 
Segundo Iwasaki (1991) e Guzzo (1992), o quartzo é composto por íons de Si e $\mathrm{O}$, e pequenas quantidades de impurezas, como $\mathrm{Al}^{3+}, \mathrm{Fe}^{3+}, \mathrm{OH}^{-}$e $\mathrm{H}_{2} \mathrm{O}$, as quais podem substituir o $\mathrm{Si}^{4+}$, gerando um desequilíbrio eletrônico. Este desequilíbrio pode ser restabelecido por íons monovalentes de $\mathrm{Li}^{+}, \mathrm{Na}^{+}, \mathrm{K}^{+}$e $\mathrm{H}^{+}$, também chamados de compensadores eletrônicos. Essa substituição natural associada a irradiação origina os centros de cor no quartzo, onde ligações do tipo Al-Li e Al-OH e/ou Fe-Li e Fe-OH influenciam na intensidade da cor no quartzo.

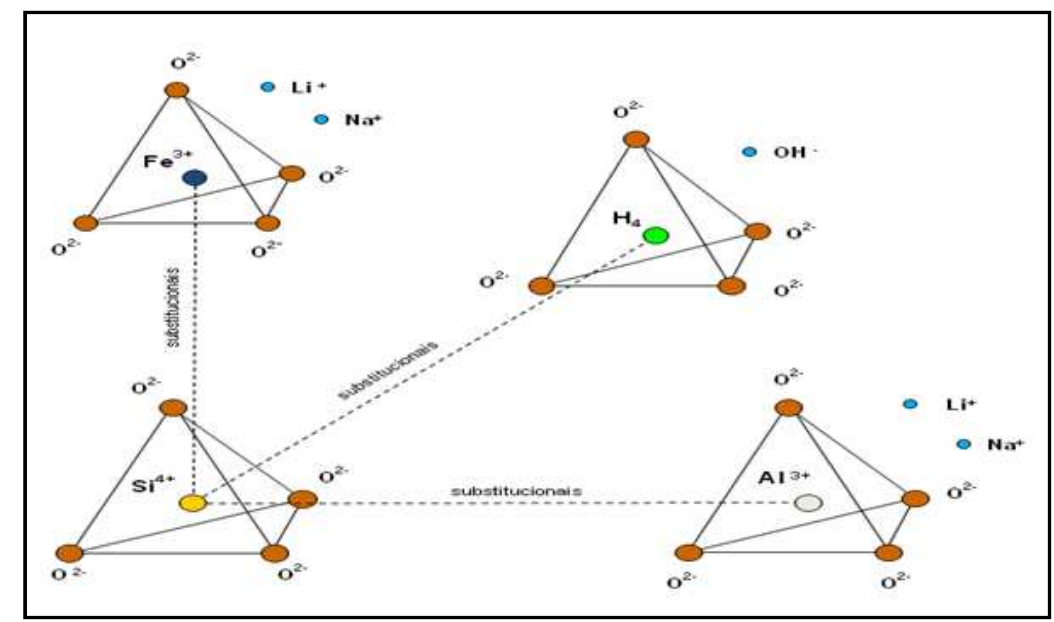

Figura 6. 8: Principais impurezas responsáveis pela coloração do quartzo. Modificado de Castaneda (2001).

A relação entre a composição química do mineral, e a predominância de determinadas variedades coloridas do quartzo, está intimamente ligada aos ambientes de formação do mineral. Conhecer essas correlações em cada ambiente geológico permite uma melhor compreensão das causas de cor nos minerais.

\subsubsection{Quartzo Fumê}

O quartzo fumê, assim como o quartzo hialino, aparece com freqüência tanto em ambientes hidrotermais, como em ambientes pegmatíticos.

Segundo Guzzo et. al. (1997), os centros de cor de alumínio do tipo Al-Li e Al$\mathrm{OH}$ são os principais responsáveis pela coloração do quartzo fumê. Os centros de cores do tipo Al-Li predominam em ambientes pegmatíticos, enquanto os centros de cor do tipo Al-OH predominam em ambientes hidrotermais. Quartzo hialino com alto 
conteúdo de Al-Li originará a cor fumê mais facilmente, quando submetidos a irradiação, do que o quartzo com alto conteúdo de $\mathrm{Al}-\mathrm{OH}$, pois a cor fumê do quartzo está predominantemente relacionada ao centro de cor Al-Li. A cor do quartzo fumê depende da relação $\mathrm{Al}-\mathrm{Li} / \mathrm{Al}-\mathrm{OH}$, cuja relação é diretamente proporcional com a formação de centros de cor no quartzo.

\subsubsection{Ametista}

De acordo com Chaves \& Coutinho (1992), e observações de campo, a maioria das ocorrências de ametista na Serra do Espinhaço estão relacionadas a depósitos hidrotermais.

Tanto na região da Serra do Espinhaço, quanto nas regiões de Jacobina e Sento Sé, a ametista encontra-se em ambientes de veios hidrotermais, a qual deve sua coloração a presença do íon de $\mathrm{Fe}^{4+}$, e à radiação ionizante natural ou artificial.

Segundo Favacho-Silva (2000), a estabilidade e a intensidade da cor da ametista está relacionada com a quantidade de irradiação absorvida e o conteúdo de Fe-OH presente em sua estrutura. Com isso, a ausência de ametista em ambientes pegmatíticos pode estar relacionada a uma menor propensão a formação dos centros de $\mathrm{Fe}-\mathrm{OH}$ nesses ambientes.

\subsubsection{Citrino}

O citrino pode se apresentar em diversas cores, como amarelo, amareloesverdeado, laranja, laranja-amarronzado a pardo-dourado. Essa diversidade de cores é proveniente não apenas de citrino de ocorrência natural, mas também daqueles produzidos através de tratamento térmico de ametista e/ou quartzo fumê, e irradiação gama em quartzo hialino (Schmetzer 1989).

Ele ocorre, assim como o quartzo fumê, tanto em ambientes hidrotermais, como em ambientes pegmatíticos. De acordo com Favacho-Silva (2000), os cristais de citrino de ambientes pegmatíticos (ricos em Li) apresentam uma coloração mais alaranjada, já os cristais observados em ambientes hidrotermais (ricos em $\mathrm{OH}$ ) tem sua coloração mais amarelo acinzentada. Segundo Iwasaki (1991), em ambiente pegmatítico, o citrino apresenta valores de 2.9 a 3.6ppm de $\mathrm{Li}$, enquanto que em 
ambiente hidrotermal, esses valores chegam apenas a 1.1ppm. Quando submetidos a tratamento térmico, cristais de citrino ricos em Li adquirem coloração amarela, e os ricos em $\mathrm{OH}$, tendem a ficar incolor.

\subsection{Características Gemológicas}

Foram analisadas gemologicamente, amostras de quartzo hialino, fumê, ametista, ametrino, hematóide, e citrino (natural e tratado), provenientes da região da Serra do Espinhaço (Serra do Salto e Brejinho das Ametistas), Serra de Jacobina, e Chapada Diamantina. As propriedades gemológicas foram obtidas através de análises em refratômetro (índice de refração), polariscópio (caráter óptico/ anisotropia e isotropia), conoscópio (figuras de interferência), difratômetro (pleocroísmo), e balança digital (densidade). As gemas analisadas não apresentaram propriedades gemológicas diferentes das observadas em minerais de quartzo de caráter gemológico, de todo o mundo.

\section{a) Ametista}

A ametista proveniente das Serras do Espinhaço e Jacobina apresenta coloração púrpura azulada a levemente púrpura, podendo mostrar manchas acinzentadas (fumê), com presença de leves a moderadas inclusões, predominantemente de Fe e/ou Mn (hematita e/ou goethita em formas de agulhas ou cogumelos), cristais negativos, inclusões bifásicas, e inclusões fluidas tipo listas de tigre, microfraturas, transparência elevada, raramente translúcida, brilho vítreo, zoneamento de cor, e estrias na superfície do cristal. Seu índice de refração mostra valores da ordem de $\omega=1.541$ e $\varepsilon=1.550$ e a birrefringência em torno de 0,009 . Apresenta densidade em torno de 2,65, e pleocroismo fraco a moderado, de matriz púrpuro/acinzentado a violeta/púrpuro. Foram analisadas 19 amostras. 


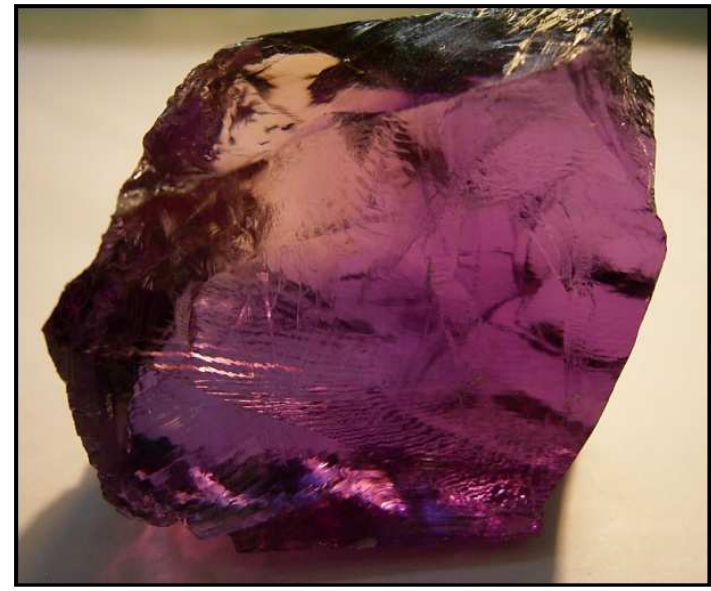

Foto 6.31: inclusões fluidas tipo listas de tigre

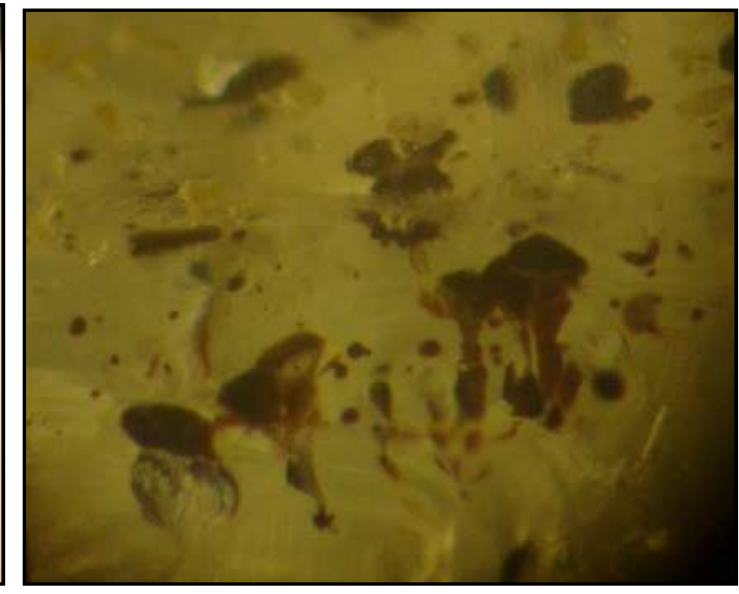

Foto 6.32: inclusões de goethita, em forma cogumelo

\section{b) Citrino}

Foram analisadas amostras de citrino natural, provenientes da região de Sento Sé, bem como citrino produzido a partir de tratamento térmico da ametista de Brejinho das Ametistas. O citrino natural analisado apresenta coloração amarelo acinzentada, algumas amostras tendem ao fumê, transparência elevada, raramente translúcida, brilho vítreo, praticamente não apresenta microfraturas e inclusões, são comuns marcas de geminação na superfície do cristal. Seu índice de refração mostra valores da ordem de $\omega=1.546$ e $\varepsilon=1.550$ e a birrefringência em torno de 0,009 . Apresentam densidade em torno de 2,65, e pleocroismo fraco, de matriz amarelo alaranjado/ amarelo acinzentado. Já o citrino proveniente da "queima" da ametista apresenta coloração amarelo alaranjada, microfraturas e pouquíssimas inclusões, índice de refração na ordem de $\omega=1.541$ e $\varepsilon=1.550$, birrefringência em torno de 0,009 , densidade em torno de 2,65, e pleocroismo ausente. Foram analisadas 8 amostras provenientes da queima de ametista, e 9 amostras de ocorrência natural. 


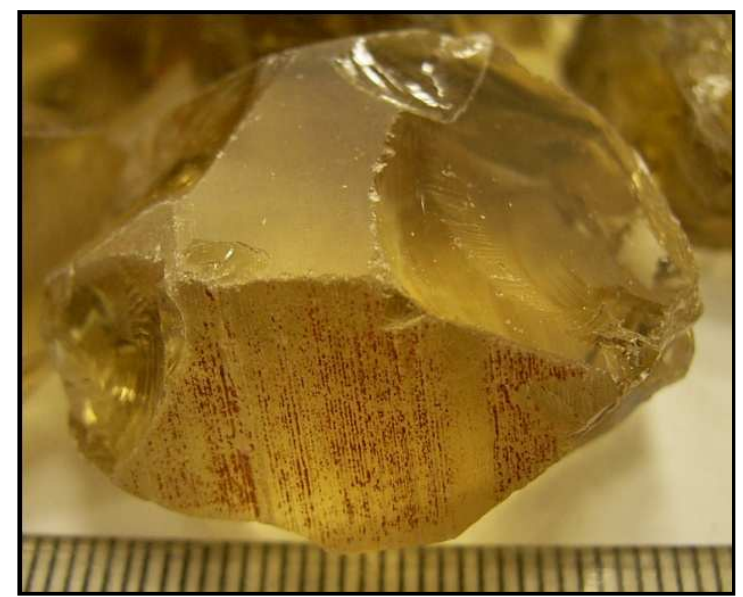

Foto 6.33: marcas de geminação na superfície do cristal de citrino de ocorrência natural

\section{c) Ametrino}

As amostras de ametrino analisadas são provenientes das regiões de Brejinho das Ametistas (Serra do Espinhaço) e Jacobina. Os cristais de ametrino são bicolores, apresentam coloração púrpura-azulada/ amarelo-alaranjada, ou púrpura avermelhada/ amarela esverdeada, podendo mostrar manchas acinzentadas (fumê), com presença de inclusões leves, normalmente de hematita, cristais negativos, e inclusões fluidas, microfraturas, transparência elevada, raramente translúcida, brilho vítreo, zoneamento de cor, e estrias na superfície do cristal. Seu índice de refração mostra valores da ordem de $\omega=1.541$ e $\varepsilon=1.550$ e a birrefringência em torno de 0,009. Apresentam densidade em torno de 2,64, e pleocroismo moderado a muito fraco, de matriz violeta/púrpuro a levemente púrpuro/acinzentado. Foram analisadas 6 amostras.

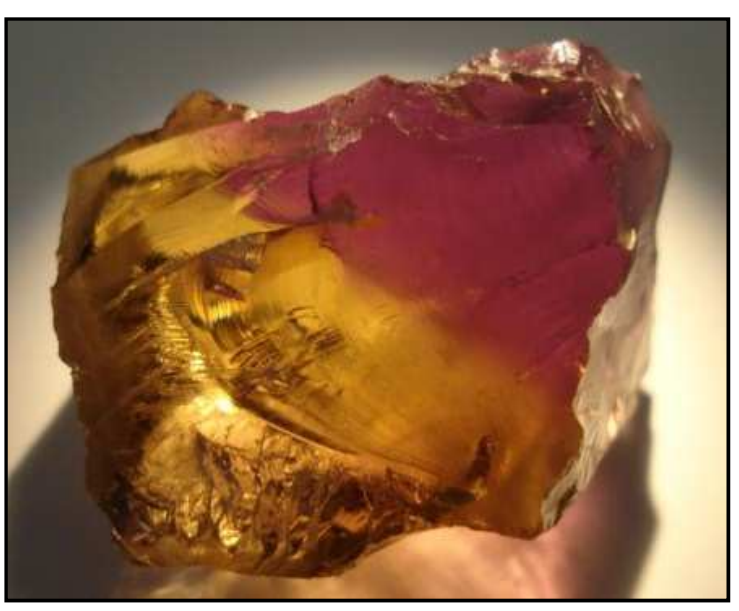

Foto 6.34: cristal de ametrino de qualidade gemológica

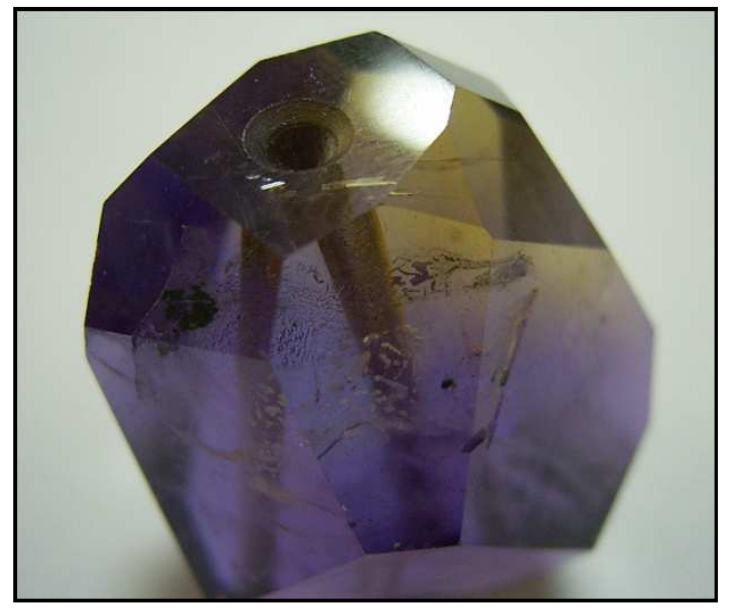

Foto 6.35: cristal de ametrino com inclusões fluidas e microfraturas 


\section{d) Quartzo fumê/ Morion}

Os cristais de quartzo fumê provenientes das regiões de Brejinho das Ametistas e Serra de Jacobina apresentam coloração acinzentada a amarronzada, podendo chegar a quase negro, como algumas amostras de Jacobina. São geralmente semitransparentes, podendo chegar a translúcidos, com presença de inclusões leves, cristais negativos, inclusões bifásicas (líquido-gás), inclusões fluidas, microfraturas com iridescência, brilho vítreo, zoneamento de cor, e estrias na superfície do cristal. Seu índice de refração mostra valores da ordem de $\omega=1.542 \mathrm{e}$ $\varepsilon=1.550$ e a birrefringência em torno de 0,008 . Apresentam densidade em torno de 2,65, e pleocroismo fraco a muito fraco, de matriz cinzento/acinzentado a acinzentado/levemente acinzentado, quase incolor. Foram analisadas 9 amostras.

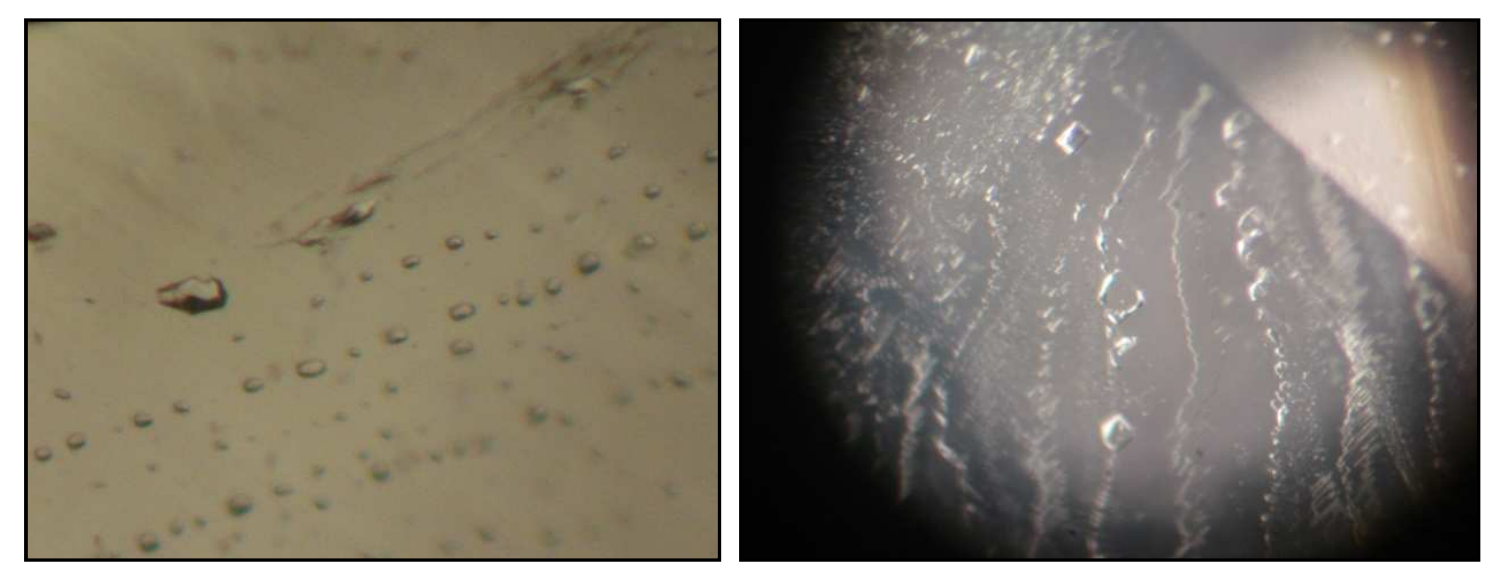

Fotos 6.36 e 6.37: cristal de quartzo fumê com presença de inclusões leves dos tipos bifásica, e cristais negativos, respectivamente

\section{e) Quartzo Hialino/ Cristal-de-Rocha}

O cristal-de-rocha das regiões da Chapada Diamantina, Serra do Espinhaço, e Serra de Jacobina são incolores, com presença de leves a moderadas inclusões, predominantemente de goethita, inclusões fluidas tipo listas de tigre e microfraturas, transparência elevada, raramente translúcidos, brilho vítreo, iridescência, e estrias na superfície do cristal. Seu índice de refração mostra valores da ordem de $\omega=1.540$ e $\varepsilon=1.549$ e a birrefringência em torno de 0,009 . Apresentam densidade em torno de 2,63 , e pleocroismo ausente.Foram analisadas 7 amostras. 


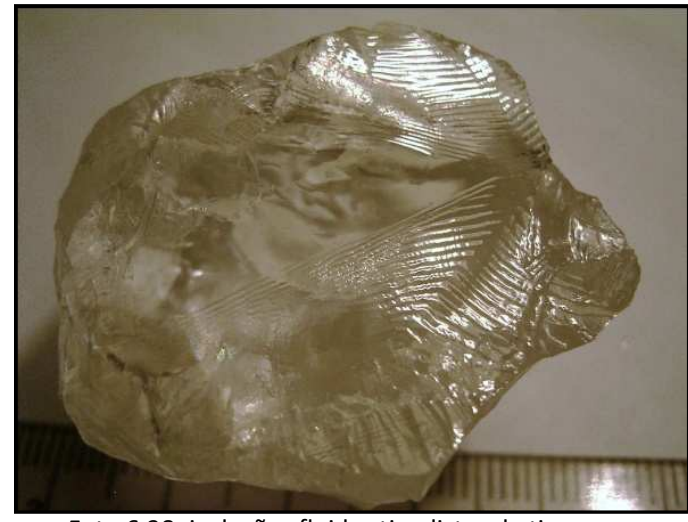

Foto 6.38: inclusões fluidas tipo listas de tigre

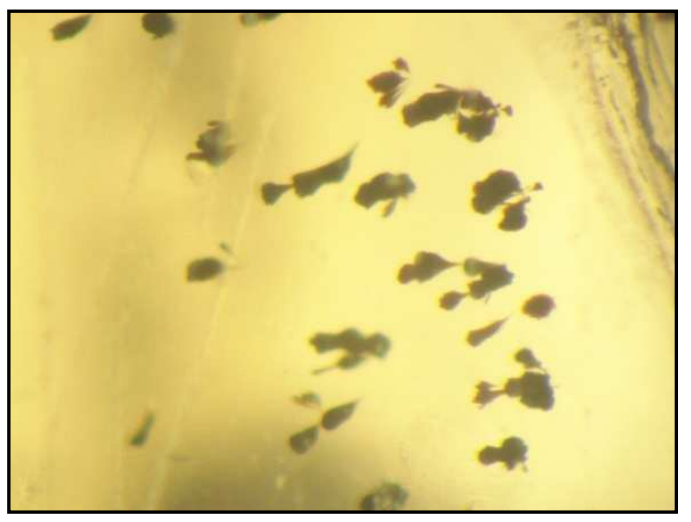

Foto 6.39: inclusões de goethita

\section{f) Quartzo Hematóide}

O quartzo hematóide ocorre somente associado à ametista da Serra de Jacobina. Os cristais de hematóide apresentam coloração vermelho amarronzado devido a elevada quantidade de inclusões de ferro (hematita em forma de agulhas) presentes no cristal. É normalmente translúcido, apresenta brilho vítreo, e constituise de uma camada cristalina com manchas vermelhas, depositada sobre uma camada de quartzo leitoso muito fraturado. Seu índice de refração mostra valores da ordem de $\omega=1.540$ e $\varepsilon=1.549$ e a birrefringência em torno de 0,009 . Apresentam densidade em torno de 2,58, e pleocroismo ausente. Foram analisadas 5 amostras.

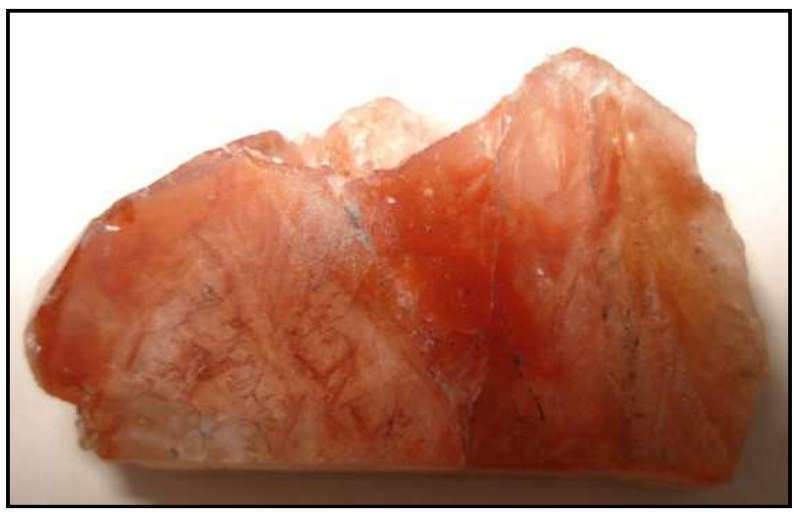

Foto 6.40: cristal de hematóide

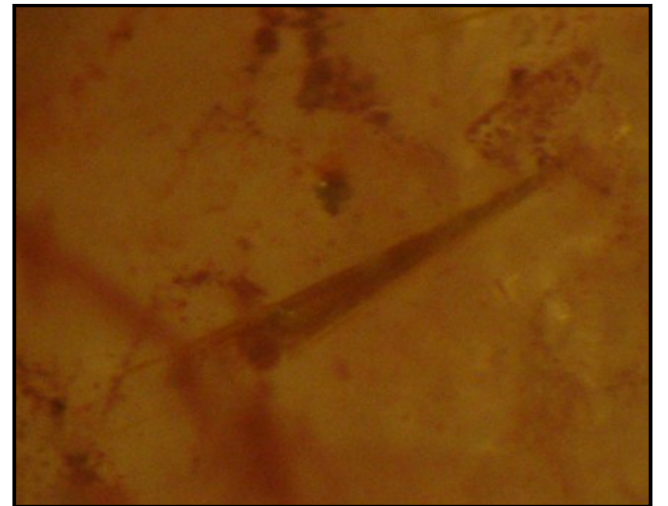

Foto 6.41: inclusões de hematita em forma de agulhas 


\section{TÉCNICAS DE BENEFICIAMENTO UTILIZADAS}

Segundo o Instituto Gemológico Americano (GIA) tratamentos em gemas são qualquer processo controlado pelo homem que possa melhorar a aparência, a durabilidade e o valor de uma gema. Dentre os tratamentos existentes, os cristais de quartzo estudados foram submetidos a tratamentos térmico e de irradiação gama. $O$ beneficiamento do quartzo por irradiação gama e tratamento térmico visa o aumento de sua qualidade gemológica, bem como o incentivo da aplicação desses tratamentos para o beneficiamento de outros minerais. Cabe ressaltar que esses tratamentos aplicados às gemas, em laboratório, não são prejudiciais a saúde.

\subsection{Irradiação Gama}

Sabendo-se que a radiação natural presente nos depósitos está relacionada com a maioria das causas de cor em cristais de quartzo, esta técnica é considerada comercialmente viável, pois não gera mudanças significativas na estrutura cristalina do mineral.

Amostras das variedades coloridas do quartzo, provenientes das Serras do Espinhaço e Jacobina e da Região da Chapada Diamantina, foram submetidas a irradiação gama, a qual usa como fonte radioativa, o cobalto-60 o qual não deixa radioatividade residual na gema.

As amostras de quartzo foram submetidas à irradiação no Irradiador Multipropósito de Cobalto-60, do Centro de Tecnologia da Radiação, do IPENCNEN/SP, que contém atualmente 32 lápis de Cobalto-60, e atividade total de aproximadamente $220.000 \mathrm{Ci}$. As amostras foram colocadas dentro de dispositivos de irradiação, confeccionados com tela de aço inox de malha fina, presa a uma armação também de aço inox, e inseridas posteriormente na piscina do irradiador. As amostras de quartzo das regiões estudadas foram separadas em lotes e irradiadas com diversas doses de Cobalto-60, até a máxima de aproximadamente $900 k$ Gy. As taxas de doses foram calculadas em função das horas de irradiação, às quais as amostras foram submetidas. As doses foram obtidas através da leitura dos dosímetros do tipo Red Perspex 4034, de polimetilmetacrilato, da empresa Harwell Dosimeters Limited, e os de triacetato de celulose (CTA), com trifenil fosfato, da Fujifilm. 
Com base nos efeitos da irradiação gama nas amostras analisadas, os seguintes resultados foram obtidos, os quais serão descritos por região:

\section{a) Serra de Jacobina}

Amostras de ametista provenientes da mina da Grota do Coxo, foram submetidas a irradiação gama. Como resposta ao tratamento, as amostras de ametista de coloração intensa, que apresentam zoneamento de cor, após a irradiação, continuaram a mostrar tal zoneamento, porém sua coloração tornou-se mais intensa.

\section{b) Sento Sé (Chapada Diamantina)}

Amostras de ametista provenientes da mina de Cabeluda, e cristais de citrino natural da mina de Careta, foram submetidos a irradiação gama. Como resultado, após irradiação, as amostras de ametista se tornaram mais escuras, com tonalidade moderada a fraca, mas também adquiriram cor amarronzada, e algumas faixas marrom-amareladas, entre as bandas lilás violeta e incolor (Monteiro 2001). Os cristais de citrino, em resposta a irradiação, adquiriram coloração muito escura, tendendo a preto, possivelmente devido a elevada quantidade de alumínio, associado a íons de $\mathrm{H}$ e $\mathrm{Li}$, existente nos cristais. Pode-se dizer apenas que as amostras estudadas possuem elevadas quantidades de Al em sua estrutura, por terem escurecido em resposta a irradiação, mas seus teores exatos são desconhecidos. No geral, o Al ocorre em teores relativamente baixos, entre 80ppm e 100ppm (Nunes et. al, 2006). Após a irradiação, as amostras foram submetidas a tratamento térmico para a mudança e melhoramento de sua cor, pois a etapa de aquecimento reverte o processo, da irradiação. Esta tapa será explicada mais adiante. 


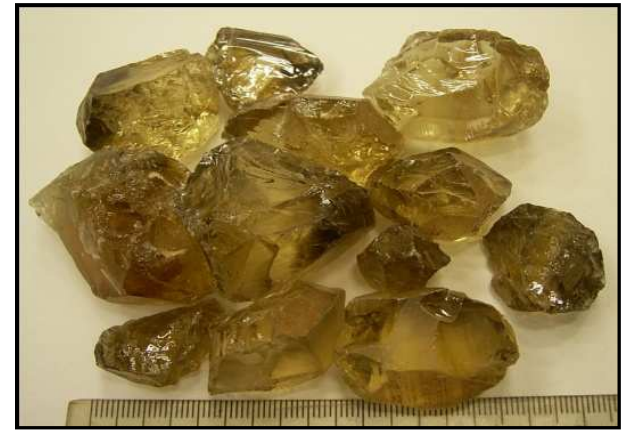

Foto 7.1: Cristais de citrino natural

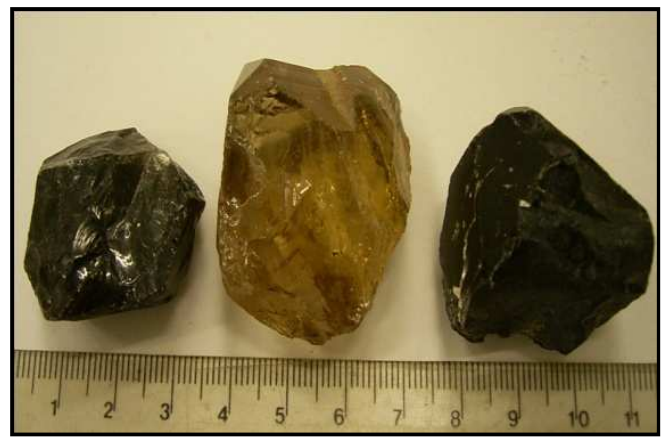

Foto 7.2: cristais de citrino irradiados

\section{c) Macaúbas (Serra do Espinhaço)}

Amostras de quartzo hialino, provenientes da região de Macaúbas/BA, depois de submetidas a irradiação, resultam em cristais de quartzo verde, de coloração verde claro, a verde acinzentado. Esses cristais apresentam alto teor de $\mathrm{H}_{2} \mathrm{O}$ e OH, os quais são os principais elementos causadores da coloração do quartzo verde (Guttler, 2008).

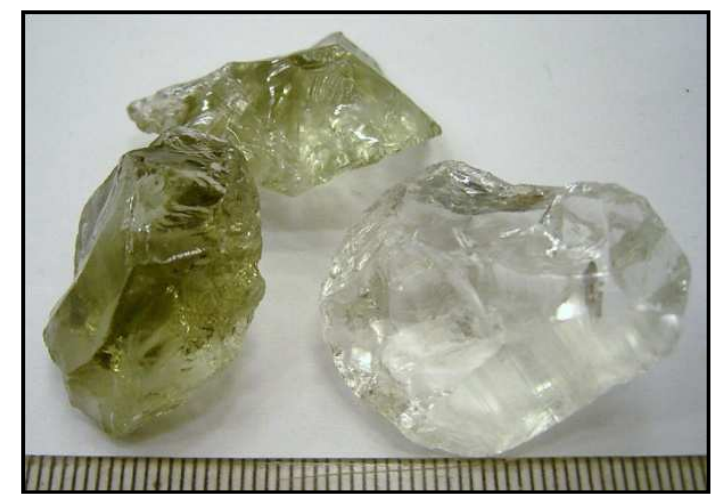

Foto 7.3: Cristais de quartzo hialino irradiados e naturais, respectivamente

\subsection{Tratamento Térmico}

O tratamento térmico é considerado um dos mais antigos tratamentos em gemas, o qual em conjunto com a irradiação proporciona ótimos resultados.

Ele é utilizado não somente para a mudança, uniformização ou melhoramento da cor nas gemas, mas também para a observação e estudo da estabilidade da cor nas gemas, desenvolvimento ou eliminação de asterismo, melhoramento da transparência por dissolução de inclusões, filtragem de cores indesejadas como, por exemplo, a presença de tons fumê em cristais de citrino natural, que tornam a gema comercialmente menos aceitável, e filtragem da saturação na cor provocada pela 
irradiação, pois grande parte das gemas irradiadas satura na cor, tomando-se escuras. Tal escurecimento pode ser filtrado através de um minucioso e adequado tratamento térmico.

O tratamento térmico foi realizado em dois fornos elétricos, um da marca Rinnai Pratic (temp. max: $330^{\circ} \mathrm{C}$ ), e o outro da Marc Cobel Digi Mec (temp. max. medida na calibragem: $647^{\circ} \mathrm{C}$ ) os quais foram calibra dos com a utilização de um termopar tipo $\mathrm{K}$ conectado a um termômetro digital MT-401a. A ponta do termopar foi revestida com um cone de Berilo perfurado para diminuir flutuações de temperaturas, a qual foi colocada no centro do forno. A calibragem foi feita a partir da temperatura de $100^{\circ} \mathrm{C}$ e a cada $50^{\circ} \mathrm{C}$ foram registr adas as temperaturas reais resultantes no termômetro. Vale ressaltar que a temperatura não ultrapassou $600{ }^{\circ}$, para não mudar as características mineralógicas do quartzo.

Foram submetidas a tratamento térmico, amostras de ametista das regiões de Brejinho das Ametistas, Serra do Salto e Jacobina, bem como amostras de citrino de ocorrência natural, da região de Sento Sé.

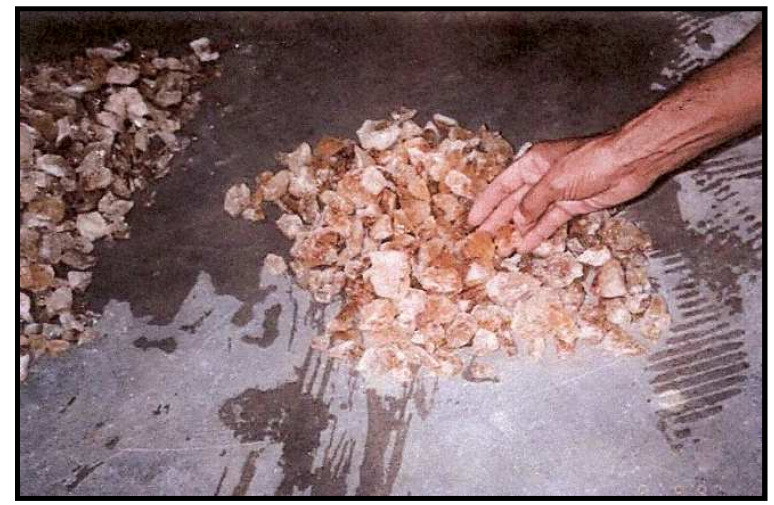

Foto 7.4: Lascas de citrino resultante da "queima" da ametista. Serra do Salto, Licínio de Almeida-BA. Fonte: (Couto et al, 2000)

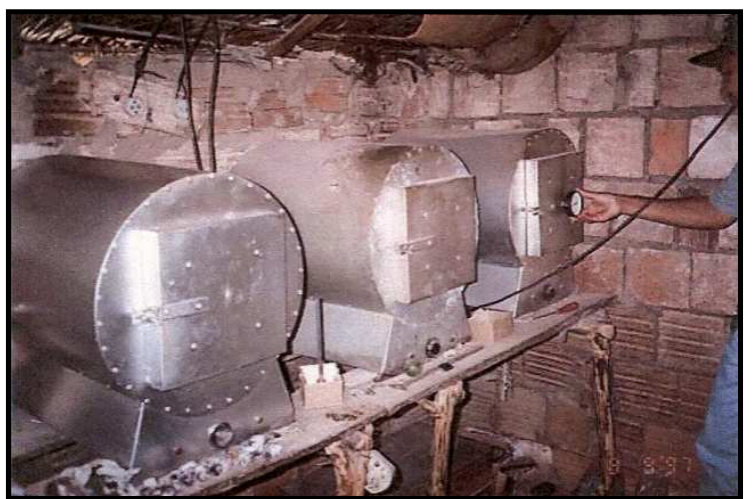

Foto 7.5: Estufas para a "queima" da ametista, Lavra do Salto, Licínio de Almeida-BA. Fonte: (Couto et al,2000)

\section{a) Ametista}

Quando a ametista é inicialmente aquecida, a cor violeta começa a clarear. Com o contínuo aquecimento, a ametista pode tomar-se completamente incolor, ou cores amarelas, verdes ou alaranjadas podem surgir, em temperaturas que variam dos $350^{\circ}$ aos $560^{\circ} \mathrm{C}$. 
Tons fumês em ametista podem ser filtrados através de tratamentos térmicos em temperaturas que não ultrapassem os $300^{\circ} \mathrm{C}$, beneficiando a gema que ficará apenas com a cor violeta. Vale ressaltar que caso esta temperatura seja ultrapassada, além da filtragem da cor fumê começará a desbotar violeta, tendendo a amostra para o incolor.

A cor da ametista é muito sensível à luz, tornando-se mais pálida quando exposta por tempo muito prolongado. Hassan (1972) e Dotto \& Isotani (1991) apresentaram estudos detalhados sobre temperaturas de perda de cor através do espectro da ametista, e sua regeneração em resposta a irradiação. Mais tarde, Vasconcelos et. al. (1994) demonstraram que a estabilidade da ametista varia de acordo com seu conteúdo de ferro, presença de $\mathrm{OH}$, e ambiente de formação. Segundo Karfunkel et . al. (1998), a foto estabilidade da ametista varia amplamente em Minas Gerais. Cristais da região de Grão Mogol perdem sua cor durante exposição ao sol em alguns dias, enquanto que cristais de ametista da região de Buenópolis e Felício dos Santos perdem sua cor a temperaturas acima de $350^{\circ} \mathrm{C}$. Uma melhor caracterização da presença dos conteúdos de ferro e hidroxila é necessária para a melhor compreensão das causas de cor e desbotamento das mesmas em cristais de ametista.

A ametista proveniente da Serra do Salto e de Brejinho das Ametistas adquiriu coloração amarela alaranjada desejada, na faixa dos $450^{\circ} \mathrm{C}$, enquanto que os cristais de ametista provenientes da Serra de Jacobina, só obtiveram coloração semelhante na faixa dos $500^{\circ} \mathrm{C}$.

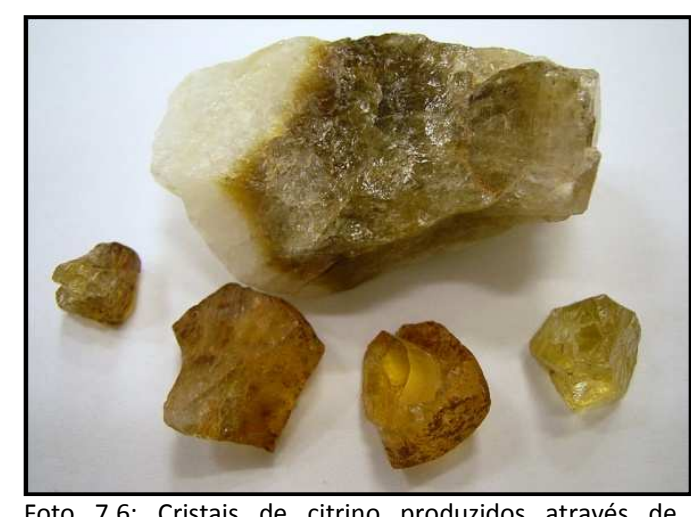

tratamento térmico em ametista da região de Jacobina.

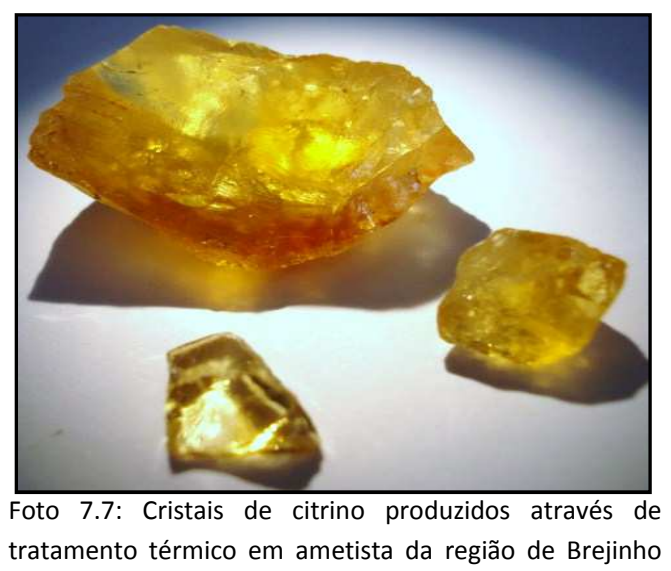

das Ametistas. 


\section{b) citrino}

Os cristais de citrino laranja-amarronzados de ocorrência natural podem ter sua coloração intensificada através de tratamento térmico a temperaturas na faixa dos 150 a $2700^{\circ}$.

A estabilidade da cor em cristais de citrino varia amplamente, pois os mesmos podem ter sua cor proveniente de íons $\mathrm{Fe}^{3+}$, ou devido a presença de centros de cor nos cristais.

Citrino de cor laranja, marrom-alaranjada e marrom, também podem ser obtidos a partir do aquecimento a baixas temperaturas (150 a $250^{\circ} \mathrm{C}$ ) de cristais de quartzo fumê.

As amostras de citrino provenientes da região de Sento Sé adquiririam a coloração alaranjada desejada, a temperaturas na faixa de $260^{\circ} \mathrm{C}$.

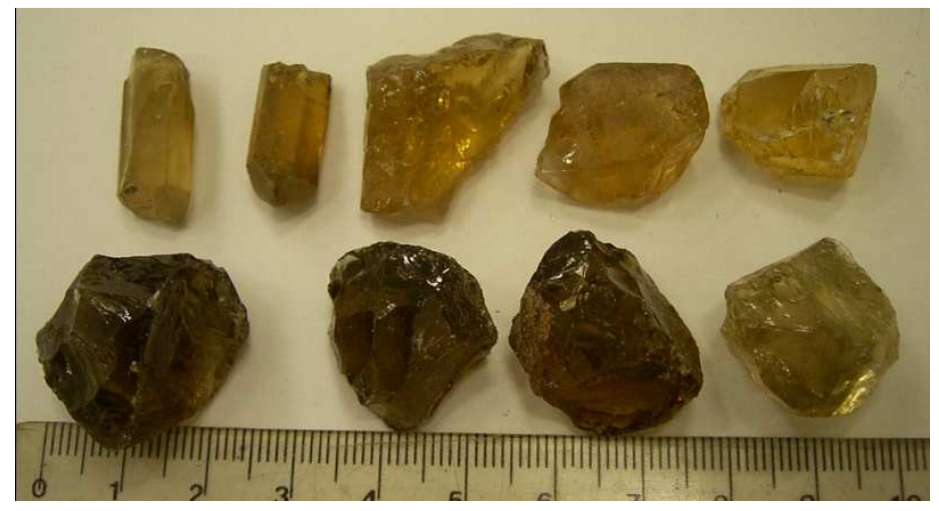

Foto 7.8: cristais de citrino de Sento Sé, após irradiação e tratamento térmico

\subsection{Leis e Órgãos de Controle de Comercialização de Gemas}

Com exceção do embelezamento do polimento e facetamento da gema, é de inteira responsabilidade do vendedor, na hora da compra, informar todo o processo envolvido no tratamento para o melhoramento da cor da gema. A não identificação de gemas naturais tratadas, quando existente, é uma prática desonesta de comércio, tais informações são exigidas em todos os níveis de comércio de gemas.

A Comissão Federal de Comércio (The Federal Trade Commission), juntamente com o comitê de vigilância dos Joalheiros (Cooperation of the Jewelers Vigilance Committee), adverte a indústria joalheira, a informar o consumidor sobre $o$ tratamento de gemas, quanto ao tipo de tratamento realizado.

A forma básica de comunicar o consumidor pode ser feita via panfletos explicativos de fácil entendimento. $O$ joalheiro deve ter conhecimento do manual de tratamento de gemas (Gemstone Enhancement Manual), editado pela Associação Americana de Comércio de Gemas - AGTA. Este manual deve ser usado no 
comércio, para indicar a possibilidade de tratamento e identificação do processo em questão, através de códigos que serão descritos a seguir.

Quanto ao tratamento das gemas de quartzo, as mesmas podem ser divididas em duas categorias básicas:

a) Gemas Não Tratadas

A letra "N" (Natural), usado para gemas não tratadas ou naturais. Esta gema deve vir acompanhada de um documento comercial tal como um atestado de laboratório gemológico garantindo o fato de a gema não ser realmente tratada.

b) Gemas Tratadas Normalmente.

A letra "G" e designada para as gemas de quartzo tratadas por irradiação gama. Enquanto a letra "H" (do inglês Heated) é usada para gemas tratadas por tratamento térmico.

No Brasil, o controle da qualidade de gemas é de responsabilidade da ABNTAssociação Brasileira de Normas Técnicas, que juntamente com o IBGM- Instituto Brasileiro de Gemas e Metais Preciosos elaboram as leis que regulamentam a qualidade de gemas no território brasileiro.

Atualmente, existem duas Normas Brasileiras sendo utilizadas pelo setor na área de gemas: $\left.1^{\circ}\right)$ NBR 10.630, classifica os materiais gemológicos e apresenta o modelo para emissão do Certificado de Identificação da Gema; 2º) NBR 12.254, refere-se a classificação de diamantes.

Em conseqüência do trabalho que vem sendo desenvolvido pelo Setor, foi criado o CB33 - Comitê Brasileiro de Normalização para Joalheria, Gemas, Metais Preciosos e Bijuteria, cuja coordenação está a cargo do IBGM. 


\section{CONCLUSÕES}

A partir dos dados levantados e discutidos, pode-se concluir que, de um modo geral, nos garimpos estudados, a mineralização do quartzo está preferencialmente posicionada em fraturas de tração de baixo ângulo, estando estas encaixadas em metarenitos e quartzitos. Tais fraturas de tração apresentam tamanhos bastante variados, desde milimétricos a métricos. São estruturas planares, com terminações abruptas geradas por processos rúpteis e estão associadas com rampas de empurrão que se desenvolveram durante as deformações que culminaram com a estruturação do cinturão de dobramentos e cavalgamentos da Serra do Espinhaço Setentrional.

Na região de Brejinho das Ametistas, a ametista estudada cresce com o eixo maior em alto ângulo com o plano de fratura, compondo uma proeminente lineação de crescimento mineral, a qual apresenta distribuição radial. A presença desta lineação de crescimento mineral sugere baixa velocidade de preenchimento das fraturas, o que pode ser um indício de que elas se desenvolveram sobre condições de alta tensão diferencial, característica de regimes compressionais. Desta forma, conclui-se que a mineralização possui um controle tectônico/estrutural.

Em vários trechos dos garimpos estudados na Serra do Espinhaço Setentrional foi notada a presença de intensa fragmentação, a qual sugere uma atuação de fraturamento hidráulico. Com isso, pode se dizer que a formação das mineralizações de quartzo em questão refletem a presença de períodos de elevada pressão de fluidos, os quais podem se relacionar ás zonas de cisalhamento compressionais da fase de inversão do Aulacógeno do Paramirim.

A ametista estudada, gerada em ambiente hidrotermal, tem sua coloração decorrente da presença de ferro em sua estrutura, a cor da ametista está associada a uma transferência de carga entre $\mathrm{Fe}^{3+}$ e $\mathrm{O}^{2-}$, o que leva a formação do íon (incomum) $\mathrm{Fe}^{4+}$ (oxidação $\mathrm{Fe}^{3+} \rightarrow \mathrm{Fe}^{4+}$ ), e da radiação ionizante. Segundo FavachoSilva (2000), em ambiente hidrotermal, a cor da ametista é resultado da presença de centros de cores do tipo $\mathrm{Fe}-\mathrm{OH}$.

O quartzo fumê estudado tem sua coloração devido a presença de alumínio em um centro de cor, o qual apresenta diferenças características, de acordo com 
seu ambiente de formação. O centro de cor Al-Li é responsável pela coloração do quartzo fumê em ambientes pegmatíticos, enquanto que em ambientes hidrotermais, o centro de cor responsável pela coloração é o Al-OH. Este último, e de mais difícil geração, mas sua cor é mais estável, o quartzo fumê gerado em ambiente hidrotermal tende a perder sua cor com menor facilidade do que o proveniente de ambiente pegmatítico.

O citrino natural estudado deve sua cor a presença de alumínio, mas as variedades das tonalidades desse material e a reação do mesmo aos tratamentos térmico e de irradiação gama, estão diretamente ligadas a presença dos íons $\mathrm{H}^{+}$ou $\mathrm{Li}^{+}$. Tal variedade não possui um ambiente típico de formação.

Dentre as mineralizações de ametista da Bahia, a única, até o presente momento, que registra um número expressivo da variedade hematóide do quartzo é a mina da Grota do Coxo, na Serra de Jacobina. Variedade esta que particulariza a mineralização de quartzo e ametista de Jacobina das demais mineralizações do Estado da Bahia. Ainda existe um potencial razoável de ametista e hematóide a serem explorados nesta mina, mas o método de lavra deve ser aperfeiçoado, ou melhor, modernizado, para garantir um maior aproveitamento e uma maior redução na relação custo-benefício da produção.

Os resultados obtidos nas análises gemológicas realizadas nas variedades coloridas do quartzo estudadas, mostra que o quartzo da Bahia apresenta um elevado potencial gemológico, com presença de inclusões leves, poucas fraturas, boa coloração, transparência elevada, índice de refração adequado, e encontraremse na faixa de 3 a $5 \mathrm{ct}$, valor razoável para gemas de cor.

As técnicas de irradiação e tratamento térmico podem valorizar as colorações das variedades coloridas do quartzo, mudando ou intensificando-as. Como exemplos, devem ser citados, o quartzo hialino da região de Macaíbas, que depois de irradiado, adquiriu coloração verde, muito apreciada no mercado gemológico, assim como o citrino natural de Sento Sé, que após tratamento térmico, ou irradiação gama seguido de tratamento térmico, adquiriu coloração amarelo alaranjada, bem como o citrino produzido através de tratamento térmico da ametista das regiões de Brejinho das Ametistas, Serra do Espinhaço e Jacobina. 
Com base nos estudos de campo e bibliografia, sabe-se que a grande maioria das reservas dos garimpos estudados são desconhecidas. O controle estrutural das mineralizações de quartzo da Serra do Espinhaço denota um elevado potencial para a descoberta de novos depósitos em subsuperfície, os quais requerem novas pesquisas com base em métodos geológicos, geofísicos, pesquisa mineral, acompanhados de escavações e sondagens, para serem localizados, e prospecção geológica em escalas regional e de detalhe.

Considerando o elevado e diversificado patrimônio mineral existente na região, com diferentes níveis de aproveitamento e disponibilidade, bem como o potencial para a expansão de recursos já conhecidos e para a descoberta de novos depósitos minerais, trabalhos futuros são sugeridos, para um maior entendimento e compreensão dos aspectos geológicos, gemológicos, estruturais e evolução metalogenética dos depósitos de quartzo do Estado da Bahia.

Apesar de ser extremamente rica em depósitos de gemas, a Bahia vem passando por um processo gradativo de falta de investimentos, significativas reduções e limitações nas suas atividades minero-industriais, e de abandono dos garimpos, seja pela parcial exaustão das reservas conhecidas, ou pela necessidade de ampliá-las e, assim, incentivar novos investimentos. Isso, certamente, decorre do fato de que na região, há mais de dois séculos, a abordagem dos depósitos de gemas é realizada de forma muito rudimentar, sem aplicação de conhecimento geológico e de técnicas de pesquisa e lavra adequadas. A atividade de garimpagem, completamente desorganizada e injusta do ponto de vista econômico, social e ambiental, vem exaurindo e inviabilizando jazidas de gemas durante todo esse tempo.

No que diz respeito ao setor de gemas e jóias, a Bahia agrega pouco valor às suas gemas, pois atua principalmente como simples fornecedor de gemas em estado bruto para outros países, pouco contribuindo para a economia estadual. A Bahia só poderá participar ativamente do mercado externo caso sejam criadas condições adequadas para o aumento de sua competitividade, com incentivo ao beneficiamento de suas próprias gemas, como investimentos em novas tecnologias 
de tratamentos em gemas de quartzo e outras variedades, bem como lapidar um maior percentual da produção estadual de suas gemas.

Segundo Castaneda (2001), dados da Embrarad (Empresa Brasileira de Radiações LTDA), indicam que apenas com o tratamento por irradiação gama, 0 quartzo é capaz de gerar valores da ordem de milhões de dólares. Após tratamento, o quartzo agrega um valor de aproximadamente $400 \%$ sobre o valor original de uma gema de cor fraca ou incolor.

Em questão de volume, a Bahia já constituiu um dos maiores produtores de cristal-de-rocha para fins comerciais visando as indústrias ópticas e eletro-eletrônica (décadas de 1940 até 1980). No entanto, atualmente este cenário é bem diferente, e este trabalho segue com o intuito de incentivar o Estado a destinar esforços para quem sabe no futuro, figurar a Bahia como um dos maiores produtores, para fins comerciais, na indústria de gemas tratadas, desde que com o advento das gemas sintéticas, as gemas naturais têm se tornado cada vez mais cobiçadas. Espera-se que as atividades de pesquisa e mineração, com base em conhecimentos geológicos, investimentos e tecnologia disponível, tornem-se economicamente organizadas e sustentáveis do ponto de vista ambiental, par que esses objetivos possam ser atingidos. 


\section{Referências Bibliográficas}

- AKHAVAN, A. C. (2005-2010) - Características e propriedades do quartzo, disponível em: www.quartzpage.de, acessado em 2008 e 2009.

- ALKMIM ET AL. (2006) - Kinematic Evolution of the Araçuaí - West Congo Orogen in Brazil and Africa: Nutcracker tectonics during the Neoproterozoic assembly of Gondwana. PrecambrianResearch, 149:43-64

- $\quad$ alkmim, F. F., MARShaK, S., Pedrosa-SoARes, A. C., PERES, G. G., CRUZ, S. C. P., WHITTINGTON, A. (2003) - A tectônica Quebra-Nozes e a Gênese do Orógeno AraçuaíCongo Ocidental. In: SBG/NRJ-ES, Simpósio Nacional de Estudos Tectônicos, 9, International Symposium on Tectonics, 3, Boletin de Resumos, 40-43.

- AlKMIM, F. F.; CHEMALE JR., F.; ENDO, I. (1996) - As Deformações das Coberturas Proterozóicas do Cráton do São Francisco e o seu Significado Tectônico. Revistada Escola de Minas, Ouro Preto, n. 1, p. 22-38.

- AlKMiM, F. F.; MARTINS NETO, M. A. A. (2001) - Bacia Intracratônica do São Francisco: Arcabouço Estrutural e Cenários Evolutivos. In: Pinto, C. P.; Martins Neto, M. A. (Ed.) A Bacia do São Francisco geologia e recursos minerais. Belo Horizonte: SBG, p. 9-30.

- AlKMIM, F. F.; NEVES, B. B. B.; ALVES, J. A. C. (1993) - Arcabouço Tectônico do Cráton do São Francisco: uma revisão. In: Misi, A.; Dominguez, J. M. L. (Ed.) O Cráton do São Francisco. Salvador: SBG, p. 45-62.

- AlmeidA, F. F. M. (1977) - O Cráton do São Francisco, Revista Brasileira de Geociências, vol. 7, no 4, p. 349-364.

- ALMEIDA, F. F. M.; HASUI, Y. (1984) - O Pré-Cambriano do Brasil. São Paulo, Edgar Blucher. $378 p$.

- ALMEIDA, F. F. M.; HASUI, Y.; NEVES, B. B. B., FUCK, R. A. (1981) - Brazilian Structural Provinces; an introduction. Earth Sci. Ver., 17: 1-29.

- APPLIN, K. R., HICKS, B. D. (1987) - Fibers of Dumortierite in Quartz. Am. Min. oㅜ 72, p.170172.

- ARCANJO, J. B. A.; SOUZA, J. D. (1984) - Projeto Mapas Metalogenéticos.

- ARCANJo, J. B. A.; VARElA, P. H. L.; MaRtins, A. A. M.; LOUREIRO, H. S. C.; NEVES, J. P. (2000) - Projeto Vale do Paramirim: Estado da Bahia, Salvador, CBPM/CPRM, Escala 1:100.000, 105p, CD-ROM.

- ARCOVERDE, W. L. (1988) - Balanço Mineral do Quartzo, Brasil Mineral, no 54, p. 24-35.

- BARBOSA, J. S. F. (1978) - Texto Explicativo para o Mapa Geológico do Estado da Bahia, Escala 1: 1.000.000 - SME/CPM, Salvador, 122p. 
- $\quad$ BARBOSA, J. S. F., DOMINGUEZ, J. M. L (1996) - Mapa Geológico do Estado da Bahia - Texto Explicativo, Salvador, Secretaria da Indústria, Comércio e Mineração, Superintendência de Recursos Minerais, 400p.

- $\quad$ BARBosA, J. S. F., SABAtÉ, P., LEITE, C. M. M. (2001) - Os Quatro Blocos Arqueanos do Embasamento do Cráton do São Francisco na Bahia e a Colisão no Paleoproterozóico. In: SBG/NNE, Simpósio Nacional de Estudos Tectônicos, 8, Anais, p. 131-133.

- BARBOSA, J. S. F.; DOMINGUES, J. L. (1994) - Mapa Geológico do Estado da Bahia ao Milionésimo, Salvador: SICM/SGM, Escala 1:1.000.000.

- BARBOSA, J. S. F.; DOMINGUEZ, J. M. L. (1996) - Geologia da Bahia: texto explicativo e Mapa Geológico do Estado da Bahia, escala $1: 1.000 .000$, Salvador, SGM, 382 p.

- BARBOSA, M. I. M.; PORPhÍRIO, N. H. (1995) - Caracterização Tecnológica de Lascas de Quartzo, 45p, Série Tecnologia Mineral, CNPq/CETEM.

- BARBOSA, O. (1965) - Geologia das Folhas de Remanso e Sento Sé - DNPM/PROSPEC, Relatório Projeto Médio São Francisco.

- $\quad$ BAStOS-LEAL, L. R., TEIXEIRA, W., CUNHA, J. C., MACAMBIRA, M.J.B. (1998) - Archean Tonalitic-Trondhjemitic and Granitic Plutonism in the Gavião Block, São Francisco Craton, Bahia, Brazil: Geochemical and geochronology characteristics. Rev. Bras. Geoc. , 2: 209-220.

- $\quad$ BASTOS-LEAL, L.R. (1998) - Geocronologia U/Pb (Shrimp), ${ }^{207} \mathbf{P b} /{ }^{206} \mathbf{P b}, \mathbf{R b}-\mathrm{Sr}, \mathbf{S m}-\mathrm{Nd}$ e K-Ar dos Terrenos Granito-Greenstone do Bloco do Gavião: Implicações para Evolução Arquena e Proterozóica do Cráton do São Francisco, Brasil. Tese de Doutorado, UNESP, São Paulo, $178 p$.

- BONS, P. D. (2001) - The Formation of Large Quartz Veins by Rapid Ascent of Fluids in Mobile Hydrofranctures, Germany, Elsevier Science, 17p.

- BRAGA, R. (1986) - Quartzo Cultivado, Aspectos da Tecnologia, Aplicações e Economia, Mineração e Metalurgia, p. 60-63.

- BRANCO, P. C. A (1984) - Principais Depósitos Minerais: Conceitos, Metodologia e Listagem, In: "Geologia do Brasil", Schobbenhaus, C. ed, Div. Geol e Mineral, DNPM,Brasília, p.359- 416.

- BRANCO, P. M. (1982) - Dicionário de Mineralogia. $2^{\underline{a}}$ ed. ver. ampl. Apresentação de Jorge Alberto Villwock. Porto alegre: UFRGS.

- $\quad$ BRANCO, P. M. (1984) - Glossário Gemológico, Ed. da UFRS, Porto Alegre, RS. p. 154.

- BRUNI, M. A.L; (1976) - Carta Geológica do Brasil ao Milionésimo, Folha Aracaju (SC.24), Brasilia - texto explicativo, MME/DNPM, 226p. 
- CARVAlHO Fo, A. R.; FROES, R. J. B.; LIMA, U. S. (1976) - Pedras Preciosas e Semipreciosas no Estado da Bahia, Salvador, vol. 1, Diagnóstico, Secretaria de Minas e Energia, Coordenação de Produção Mineral.

- CARVAlHO, A. S. (1982) Geologia e Gênese das Mineralizações de Quartzo no Espinhaço Meridional, Minas Gerais - Brasil. Dissertação de mestrado - UNB, Brasília, 127p.

- CASSEDANE, J. P.; CASSEDANE, J. O. (1979) - La Mine D'amethyste de la Grota do Coxo: Une Merveille Inconnue. Rev. Gemmologie, 59: 2-5.

- CASsedAnNE, J. (1971) - Geologia da Algumas Jazidas de Gemas. Boletim de Geologia, Rio de Janeiro, no 6 , p. 12-21.

- CASsedanne, J. A, SAUER, D. (1987) - Classification of Gemstone Deposits in Brazil Anais: XXI Conf. Int. de Gemol, Rio de Janeiro, p.7-20.

- CASSEDANNE, J. P., RODITI, M. (1991) - Crystallized and massive rose quartz deposits in Brazil, J.Gemmology, 22, p.273-286.

- CASSEDANNE, J.O. \& J.P. CASSEDANNE (1979) - As Jazidas Brasileiras de Ametista.

- CAStañedA, C; ADDAD, J. E.; LICCARDO, A. FAVACHO, M. (2001) - Gemas de Minas Gerais, 1ed, Belo Horizonte: SBG/MG, p.220-233.

- CHAVES, M. L DE S. C.; KARFUNKEL, J.; TUPINAMBÁ, M. (2003) - Estruturação "em rosário" dos Depósitos de Quartzo Hidrotermal do Morro do Juá (Gouveia, MG), R. Esc. Minas - REM, Ouro Preto, p. 15-20.

- ChAVES, M. L. S. C., BRITO, W., FAVACHO-SILVA, M. D. (1999) - Tipologia dos depósitos de quartzo gemológico em Minas Gerais e regiões adjacentes. In: Simp. Geol. de Minas Gerais e Centro-Oeste, 10, Brasília, p.42.

- ChaVES, M. L. S. C., KARFUNKEL, J., QUEMENEU, J., ADDAD, J. (1997) - Depósitos de quartzo da região de Batatal (Diamantina, MG). In: Simp. Geol. Minas Gerais, 9, Ouro Preto, Bol. 14, p.103-104.

- COHEN, A. J. (1956) - Color center in the alpha-quartz called amethyst, 36th Annual Meeting of the Mineralogical Society of America, New Orleans, Louisiana, p.874-881.

- COHEN, A. J., HASSAN, F. (1974) - Ferrous and ferric ions in synthetic and natural amethyst, Am. Min., 59, p.719-728.

- CORDANI, U. G., IYER, S. S., TAYLOR, P. N., KAWASHITA, K., SATO, K., MCREATH, I. (1992) $\mathrm{Pb}-\mathrm{Pb}, \mathrm{Rb}-\mathrm{Sr}$, and $\mathrm{K}-\mathrm{Ar}$ sistematic of the Lagoa Real uranium province (south-central Bahia, Brazil) and the Espinhaço Cycle (ca. 1.5-1.0 Ga), Journal of South American Earth Sciences, vol. $5, \mathrm{n}^{\circ}$ 1, p. 33-46

- COSTA, L. A. M. \& SILVA, W. G. (1980) - Projeto Santo Onofre: Mapeamento Geológico. Relatório Final, Brasília, vol. 1, DNPM/CPRM. 
- COSTA, L. A. M.; INDA, H. A. V. (1982) - O aulacógeno do espinhaço. Rev. Ciências da Terra, ํ․ 1, p. 13-18.

- COUTO, P. A.; SAMPAIO, A. R.; GIL, C. A. A. (1978) - Projeto Serra de Jacobina: geologia e prospecção geoquímica, Relatório final, Salvador, DNPM/CPRM.

COUTO. P. A. A. de. (2000) - Mapa Gemológico do Estado da Bahia, Texto explicativo, Salvador: CPRM.

- COX, R. T. (1977) - Optical absorption of the ion Fe4+ in pleochroic amethyst quartz, J. Phys, Solid State Phys, 10, p.4631-4643.

- $\quad$ CRUZ S. C. P. \& ALKMIM F. F. (2002) - O Arcabouço Estrutural dos Gnaisses Lagoa Real na Porção Sul do Corredor do Paramirim (BA): Evidências do Envolvimento do Embasamento do Cráton do São Francisco Durante a Interação Brasiliana Entre o Corredor do Paramirim e a Faixa Araçuaí- Oeste Congo. In: SBG/NNE, Cong. Bras. de Geolog., 46, p. 301.

- $\quad$ CRUZ, S. C. P \& ALKMIM F. F (2004, 2006) - CRUZ, S.C.P. \& ALKMIM, F.F. (2006). The tectonic interaction between the Paramirim Aulacogen and the Araçuaí Belt, São Francisco Craton region, Easter Brazil. Anais da Academia Brasileira de Ciências, 1: 151-173p.

- CRUZ, S. C. P.; ALKMIM, F. F. (2005) - A Interação Tectônica entre o Aulacógeno do Paramirim e o Orógeno Araçuaí- oeste Congo. In: Simp. Sobre o Cráton do São Francisco, 3., Salvador, p. 215-218.

- CRUZ, S. C. P. (2004) - Tectônica do Embasamento na Porção Sul do Corredor do Paramirim-MG/BA e sua relação com o orógeno Araçuaí-Oeste Congo. Tese de Doutorado, UFOP, Ouro Preto, 505p.

- DANA, J. D., HURLBUT, C. S. (1969) - Manual de Mineralogia, Revisto por Cornelius S. Hurlbert Júnior, Tradução de Rui Ribeiro Franco, $1^{\underline{a}}$ ed. $5^{\underline{a}}$ ver., Rio de Janeiro, Livros Técnicos e Científicos, Editora S.A, p. 528-530

- DANDERFER Fo. (1990) - A Analise estrutural descritiva e cinemática do Supergrupo Espinhaço na região da Chapada Diamantina (BA), Dissertação de Mestrado, UFOP, Ouro Preto, 119p.

- DANDERFER Fo. (2000) - A Geologia Sedimentar e Evolução Tectônica do Espinhaço Setentrional, Estado da Bahia, Tese de Doutorado, UNB, Brasília, 498p.

- DANDERFER Fo., A. \& DARDENNE, M. A. (2002) - Tectonoestratigrafia da Bacia Espinhaço na porção centro-norte do Cráton do São Francisco: registro de uma evolução poli-histórica descontínua. Rev. Bras. Geoc., 4: 449-460.

- DELGADO, I. M.; SOUZA, J. D. ; SILVA, L. C. et al. (2003) - Geotectônica do Escudo Atlântico. In: Bizzil, L. A.; Schobbenhaus, C.; Vidottil, R. M. et al. (Ed.) Geologia, Tectônica e Recursos Minerais do Brasil: Texto, Mapas \& SIG. Brasília: CPRM, p. 227-332.

- DIANA, F. R. (2004) - Pedras Brasileiras. Ed. Reler, Rio de Janeiro, 124p. 
- $\quad$ DINIZ, F. L. C; ARCOVERDE, W. L. (2000) - Quartzo (cristal), Sumário Mineral, Brasília.

- DOMINGUEZ, J. M. L. (1992) - As coberturas do Cráton do São Francisco: Uma abordagem do ponto de vista da análise de bacias. In: Dominguez, J. M. L. \& Barbosa, J. S. F. (Ed.) O Cráton do São Francisco, SGM, pp. 137-159.

- DOMINGUEZ, J. M. L. (1996) - As Coberturas Plataformais do Proterozóico Médio e Superior. In: Barbosa J.S.F.\& Dominguez, J.M.L. (Ed.), Mapa Geológico do Estado da Bahia, Texto Explicativo, p.109-112, Salvador, vol. 2, Convênio DNPM/CPRM.

- DOMINGUEZ, J. M. L. (1996) - Geologia da Bahia: texto explicativo para o mapa geológico ao milionésimo, Salvador, SICT/SGM, p.105-125

- DOSSIN, I. A., UHLEIN, A., DOSSIN, T. M. (1984) - Geologia da Faixa Móvel Espinhaço em sua porção meridional - MG. In: 33 Congr. Bras. Geol., Rio de Janeiro, p.3118-3132.

- DOSSIN, T. M. (1994) - Associations volcano-plutoniques de I'Espinhaço Meridiollal (SEBresil), Tese de Doutorado, France: Univ. d'Orleans, 177p.

- FAVACHO-SILVA, M. D. (2000) - Variedades gemológicas de quartzo em Minas Gerais: geologia, mineralogia, causas de cor, técnicas de tratamento e aspectos mercadológicos, Dissertação de Mestrado, Belo Horizonte: IGC/UFMG, 182p.

- FRISTSCH, E. \& ROSSMAN, G. R (1987) - An update on color in gems. Part 1: Introduction and colors caused by dispersed metal ions, Gems \& Gemology, 23, p.128-138.

- FRISTSCH, E. \& ROSSMAN, G. R. (1988) - An update on color in gems. Part 2: Color Involving Multiple Atoms and Color Center, Gems \& Gemology, 24, p.3-15.

- FYFE, W. S. (1978) - Fluids ill the earth's crust, New York: Elsevier, 325p.

- FYFE, W. S. (1964) - Geochemistry of Solids, Mcgraw-Hill Book Co., New York.

- GIA (1990) - Gem Reference Guide, Published by the Gemological Institute of America.

- GUTTLER R. A. S.; HENN, U.; MILISENDA, C. C.; (2008) - Grüne Quarze-Farbusachen und Behandlung, Gemmologie 57 Heft 1, p. 61-71.

- GUTtLeR, R. A. S. (2006) - "Safirita”, o Quartzo Azul Brasileiro, Diamond News, ano 6, no 25, p.45.

- GUTTLER, R. A. S. (2008) - Quartzo Verde ou Prasiolita?, Diamond News, Ano 8, n²8, p. 1928.

- Guttler, R. A. S.; ENOKIHARA, C. T.; RELA, P. R. (2009) - Characterization of Color Centers in Quartz Induced by Gamma Irradiation. International Nuclear Atlantic conference INAC, Rio de Janeiro.

- GUTTLER, R. A. S.; HENN, U. (2009) - Colour-enhanced quartz and its identification: Green, Violet-blue and yellow-green quartz from Brazil, The Canadian Gemmologist, Volume 30, n², p. 46-54. 
- GUTTLER, S. R. AND KOHIGASHI, H. C. (2006) - Treated violetish blue to violet quartz from Brazil, Gems \& Gemology 42, p. 285-286.

- GUZZO, P. L. (1992) - Caracterização de impurezas estruturais e de centros de defeitos relacionados ao Al e OH no quartzo natural, Dissertação, UNICAMP.

- GUZZO, P. L., IWASAKI, F., IWASAKI, H. (1997) - Al-related centers in relation to Y-irradiation (Response in natural quartz), Phys. Chem. Miner., 24, p.254-263.

- GUZZO, P. L.; MIRANDA, M. R.; LUZ, A. B. (2009) - Espectroscopia Infravermelha à Baixa Temperatura em Quartzos e Ametistas com Altas Concentrações de $\mathrm{OH}$ e $\mathrm{H}_{2} \mathrm{O}$, Rev. Esc. Minas vol.62, nํㅜ, Ouro Preto, 12p.

- HASSAN, F. (1972) - Amethyst, Min. Rec., 3, p.221-225.

- INDA, H. A. V. \& BARBOSA, J. F. (1978) - Texto Explicativo para o Mapa Geológico do Estado da Bahia, Escala 1:000.000, Salvador: SME/CPM, 1978. 237p., mapa anexo.

- KARFUNKEL, B. \& KARFUNKEL, J (1976) - Geologia da Serra do Espinhaço no Norte de Minas Gerais (Itacambira-Botumirim). In: Congr. Bras. Geolog., 29, Ouro Preto, vol.2, p.169-178.

- KARFUNKEL, J., ADDAD, J., PINHEIRO, M., KRANBROCL, K., LAMEIRAS, F., BANKO, A, HADRIAN, W. (2000) - Temperature time bleaching reaction in smoky quartz: nature and experiment, Congr. Int. Geol., Rio de Janeiro - RJ.

- KARFUnKEL, J., QUEMENEUR, J., CHAVES, M. L. S. C., BANKO, A., LAMEIRAS, F. S., PINHEIRO, M. V. B., PFANNES, H. D. (1998) - A ametista de Grão Mogol (MG): ocorrência, descrição e métodos de tratamento. In: Congo Brasileiro de Geologia, p.263.

- KARKUNFEL, J., CHAVES, M. L. S. C., BANKO, A. G. HOOVER, D. B. (1998) - Colluvional Diamond and Quartz Deposits from the Espinhaço Range: genesis and economic importance. In: Cong. Bras. Geolog., 40, Belo Horizonte, p.272.

- KLEIN, C. (2002) - Manual of Mineral Science, New York: John Wiley, 22 ed., p. 475 -480.

- KLEIN, C., HURLBUT, C. S. (1993) - Manual Of Mineralogy. John Wiley\&Sons, Inc.

- LEHMANN, G. (1971) - The structure of yellow iron centers in quartz, Phys. Stat. Sol. (b), 48, p.65-67.

- LEHMANN, G. (1971) - Yellow color centers in natural and synthetic quartz, Phys. Kondens Materie, 13, p.297-306.

- LEHMANN, G., MOORE, W. J. (1966) - Optical and paramagnetic properties of iron centers in quartz. J. Chem. Phy., p.1741-1745.

- $\quad$ LIMA, S. A. R. P. dos. (2004) - Guia de Mineralogia. 144 p. GEOSOL/ Fundação Victor Dequech.

- LOUREIRO, H. S. C. (2009) - Geologia e Recursos Minerais da Parte Norte do Corredor do Paramirim, Projeto Barra-Oliveira dos Brejinhos, Estado da Bahia., Salvador, CBPM/CPRM, Escala 1 :200.000, 2 mapas anexos, 118p., (série arquivos abertos, 33) 
- LUZ, A. B. e BRAZ E. (2000) - Quartzo: Série Rochas e Minerais Industriais, no 2. CETEM/MCT, Rio de Janeiro, RJ, 5-6.

- LUZ, A. B.; LINS, F. A. F.; PIQUET, B.; COSTA, M. J.; COELHO, M. J. (2003) - Pegmatitos do Nordeste: Diagnóstico sobre o Aproveitamento Racional e Integrado - Série Rochas e Minerais Industriais, no 9. CETEM/MCT, Rio de Janeiro, RJ, p79.

- MARTINS, A. A. M. (2008) - Geologia da Chapada Diamantina (Projeto Ibitiara-Rio de Contas), Salvador, CBPM/CPRM, 68p., (Série Arquivos Abertos; 31).

- MARTINS-NETO, M. A.; ALKMIM, F. F. (2001) - Estratigrafia e evolução tectônica das Bacias Neoproterozóicas do Paleocontinente São Francisco e suas margens: registro da quebra de Rodinia e colagem de Gondwana. In: Pinto, C. P.; Martins-Neto, M. A. (Ed.), Bacia do São Francisco: geologia e recursos naturais, Belo Horizonte, 349 p., p. 31-54.

- MASCARENHAS, J. F. (1976) - Estruturas do tipo "Greenstone belt" no Leste da Bahia. In: Cong. Bras. Geolog., 29, Ouro Preto, vol. 4, p. 25-49.

- MASCARENHAS, J. F.; SILVA, E. F. A. (1994) - "Greenstone Belt' de Mundo Novo: caracterização e implicações metalogenéticas e geotectônicas no Cráton de São Francisco, Salvador, CBPM, (Serie Arquivos Abertos, 5).

- MASChMEYER, D., LEHMANN, G. (1983) - New hole centers in natural quartz. Phys. Chem., p.84-88.

- MASchmeYeR, D., NiEMANN, K., HAKE, H., LeHMANN, G., RAUBER, A. (1980) - Two modified quartz centers in natural citrine. Phys. Chem. Min., p.145-156.

- MC MILLAN, P. F., HOFMEISTER, A. H. (1988) - Infrared and Raman Spectroscopy. In: Spectroscopy Methods in Mineralogy and Geology. p.99-159.

- MEDINA, A. R. C.; GRIFFON, J. C. (2002) - Caracterização e potencialidade mineral do município de Brotas de Macaúbas-BA, Salvador, CBPM, disponível em: http://www.cbpm.com.br, acesso em: 30 out. 2009.

- MISI, A.; et. al. (2006) - Metalogenético do Estado da Bahia. Texto Explicativo. Mapas. CBPM/CPRM.

- MISI, A.; SILVA, M. G. (1996) - Chapada Diamantina Oriental, Bahia: geologia e depósitos minerais, Salvador, SGM, 194p.

- MONTEIRO, C. V. (2001) - Caracterização das ametistas brasileiras em face aos efeitos da radiação gama e seu tratamento térmico, Dissertação de Mestrado, Rio Claro - SP, UNESP, $65 p$.

- NASSAU, K. (1984) - Gemstone Enhancement. 2o ed., Ed. Butherworths, London, 221p.

- NUNES, E. H. M. (2005) - Investigação da formação da cor no quartzo de São José da Safira, (MG), Tese de Mestrado, Centro de Desenvolvimento da Tecnologia Nuclear - CDTN, Belo Horizonte. 
- NUNES, E. H.M., LAMEIRAS, F.S. $(2005,2006)$ - The Optical Absorption of Gamma Irradiated and Heat-Treated in Natural Quartz, Materials Research, 8, pp. 305-308.

- O'BRIEN, M. C. M. (1955) - The structure of the colour centeres in smoky quartz, p.404-414.

- O'BRIEN, M. C. M., PRYCE, M. H. L. (1955) - Paramagnetic resonance in irradiated diamond and quartz: interpretation. In: Efects in Crystalline Solids: report of the conference on defects in crysstalline solids, The Physical Society, London, p.88-91.

- PAIVA, G. de. (1946) - Províncias pegmatíticas do Brasil. Rio de Janeiro: DNPM-DFPM, (Boletim 78).

- PATI, J. K.; PATEL, S. C.; PRUSeTH, K. L.; MALVIYA. V. P.; ARIMA, M.; RAJU, S.; PATI, P.; PRAKASH, K. (2007) - Geology and Geochemistry of giant quartz veins from the Bundelkhand Craton, central India and their implications, India, p. 497-510.

- PFLUG, R. \& RENGER, F. (1973) - Estratigrafia e evolução geológica da margem SE do Cráton São franciscano - $27^{\circ}$ Cong. Bras. Geol, Aracaju, p.5-19.

- PIMENTEL, M. M., MACHADO, N., LOBATO, L. M. (1994) - Geocronologia U/Pb de rochas graníticas e gnáissicas da região de Lagoa Real, Bahia, e implicações para a idade da mineralização de urânio. In: Congresso Brasileiro de Geologia, 38, Boletim de Resumos Expandidos, p. 389-390.

- POUGH, F.H. (1969) - The Jacobina Amethyst Mine, Lapidary Journal 22(10): 1306-1308.

- Rela, P. R.; CAlvo, W. A. P.; NAPOlitano, C. M.; KOdAMA, Y.; COSTA, F. E. DA; FERREIRA, D. C.; ANDRADE E SILVA, L. G. (2005) - Programa de qualificação de um irradiador multiproposito de cobalto-60 tipo compacto, International Nuclear Atlantic Conference INAC2005, Santos, Brazil, ABEN.

- ROCHA, A. J. D. (1997) - Morro do Chapéu, folha SC.24C-V. Programa Levantamentos Geológicos Básicos do Brasil, Geologia e Metalogênese. Escala 1:100.000, Estado da Bahia. Brasília, CPRM, 134p., e 2 mapas.

- $\quad$ ROCHA, A. J.D. (1998) - Programa Levantamentos Geológicos Básicos do Brasil. Geologia e Metalogênese. Escala 1:100.000. 2 mapas. Apêndices. CPRM, 134 p.

- ROCHA, G.M. F. (1998) - Distrito manganesífero de Urandi-Licínio de Almeida, Bahia: Geologia e Potencialidade Econômica. Salvador.CBPM.

- ROCHA, G.M.F. (1991) - Projeto distrito manganesífero do sudoeste da Bahia. Superintêndência de Geologia e Mineração - SGM, Salvador, Bahia.

- ROSSMAN, G. R. (1994) - Colored varieties of the silica minerals, Reviews in mineralogy, Mineralogical Society of America, vol.29, p.433-467.

- SÁ, E. F. J. (1981) - A Chapada Diamantina e a Faixa Santo Onofre: um exemplo de tectônica intraplaca no Proterozóico Médio do Cráton São Francisco. In: Inda, H. A. V.; Marinho, M. M.; 
Duarte, F. B. (Ed.) Geologia e Recursos Minerais do Estado da Bahia: textos básicos. Salvador: SME/COM, 1981. vol. 4, p. 111-120.

- SÁ, E. F. J.; BARTELS, R. L.; NEVES, B. B. B. (1976) - Geocronologia e modelo tectomagmático da Chapada Diamantina e Espinhaço Setentrional, Bahia. In: Cong. Bras. Geolog., 29, Ouro Preto, vol. 4, p. 205-227.

- SÁ, H. S. (2002) - Desempenho da Mineração na Bahia, 1989-2000, SICOMIN (programa), Salvador-BA, Governo do Estado da Bahia.

- SABATÉ, P.; BARBOSA, J. S. F. (2000) - Archean and Paleoproterozoic Tectonic Evolution of the São Francisco Craton, Brazil. In: Cordani, U. G.; Milani, E. J.; Thomaz Filho, A. et al. (Ed.) Tectonic Evolution of South America. Rio de Janeiro: 31st Internacional Geological Congress, p. 101-137.

- SCHMETZER, K. (1989) - Methods for the distinction of natural and synthetic citrine and prasiolite, J. Gemmology, 21, p.368-391.

- SCHOBBENHAUS, C. (1972) - Relatório geral sobre a geologia da região setentrional da Serra do Espinhaço: Bahia Central, nota explicativa do mapa geológico 1:250.000, Recife, Sudene, $112 \mathrm{p}$.

- SCHOBBENHAUS, C. (1993) - O Proterozóico médio do Brasil com ênfase na região centroleste, uma revisão, Tese de Doutorado, Albert-Ludwings-Universitat, Freiburg-Alemanha, 166p.

- SCHOBBENHAUS, C. (1996) - As tafrogêneses superpostas Espinhaço e Santo Onofre, Estado da Bahia: revisão e novas propostas, Revista Brasileira de Geociências, vol. 26, ㄲo4, p.265-276.

- SCHOBBENHAUS, C.; HOPPE, A.; BAUMANN, A. (1994) - Idade U/Pb do vulcanismo Rio dos Remédios, Chapada Diamantina, Bahia. In: Cong. Bras. Geolog., 38, Balneário Camboriú, Boletim de Resumos Expandidos, vol. 2, p. 397-398.

- SCHOBBENHAUS, C.; KAUL, P. F. T. (1971) - Contribuição à estratigrafia da Chapada Diamantina, Bahia Central. Mineração e Metalurgia, vol. 53, № 315, p. 116-120.

- SCHUMMAN. W. (2006) - Gemas do Mundo - Editora ao Livro Técnico, traduzido por Mário Del Rio, 9a Edição, p. 116-122.

- SILVA, A. J. C. L. P. (1994) - Supergrupo Espinhaço na Chapada Diamantina no CentroOriental, Bahia: sedimentologia, estratigrafia e tectônica, Tese de Doutorado, USP, São Paulo, $126 p$.

- SMITH, G., STRENS, R. G. J. (1976) - Intervalence transfer absorption in some silicate, oxide and phosphate minerals. In: R. G. J. Strens, Kd., The Physics and Chemistry of Minerals and Rocks, John Wiley \& Sons, New York, p.583-612. 
- SOUZA, J. D.; MELO, R. C.; KOSIN, M.; JESUS, J. D. A.; RAMOS, A. M. B. (2003) - Geologia e Recursos Minerais do Estado da Bahia: Sistema de Informações Geográficas-SIG e Mapas. Versão 1.1. Salvador, CPRM, 1 CD-ROM.

- StOIBER, E. R.; TOLMAN, C.; BUTLER, D. R. (1945) - Geology of Quartz Cristal Deposits, American Mineralogist, Vol. 30, p 219-229.

- SVISERO, D.; FRANCO, R. R.(1991) - Província gemológica brasileira. In: Schobbenhaus, C.; Queiroz, E. T.; Coelho, C. E. S. Principais depósitos minerais do Brasil: gemas e rochas ornamentais. Brasília: DNPM/CPRM, vol. 4, parte A, p. 9-16.

- $\quad$ tavares, S. A.; ANDRADE, C, A, de.; BAIÃO, S. M. G.; GAMA, N. L. J. da.; SILVEIRA, G. A. L. da.; LEITE, M. W. (1998) - Manual Técnico de Gemas - DNPM, IBGM, 112 p.

- TURPIN, L., MARUĖJOL, P., CUNEY, M. (1988) - U-Pb, Rb-Sr and Sm-Nd chronology of granitic basement, hydrothermal albitites and uranium mineralization, Lagoa Real, South Bahia, Brazil. Contrib. Mineral. Petrol.,98: 139-147.

- UHLEIN, A. (1986) - Contribuição a geologia estrutural e tectônica das rochas arqueanas e proterozóicas da Serra do Espinhaço Meridional. In: Congr. Bras. Geol., 34, p.1191-1199.

- UHLEIN, A.; TROMPETTE, R. (1997) - As faixas dobradas Araçuaí-Paramirim e os eventos geológicos no limite meso-neoproterozóico. In: Simp. Geolog. De Minas Gerais, 9, Ouro Preto, p. 34-35.

- VAIL, P. R.; MITACHUM JUNIOR, R. M.; TODD, R. G. (1977) - Seismic stratigraphy and global changes of sea level. In: Payton, C. E., Seismic Stratigraphy Applications to Hydrocarbon Exploration. Tulsa: AAPG, p. 49-212. (AAPG Memoir, 26).

- VAsconcelos, P. M., WENK, H. R., ROSSMAN, G. R. (1994) - The Anahi ametrine deposit, Bolivia, Gems and Gemology, vol.30, p.4-23.

- VULTEE, J. V. (1955) - Uber die orientierten werwachsungen von rutil in quartz, N. Jb. Min. Abh., p.389-415.

- VULTEE, J. V., LIETZ, J. (1956) - Uber die rolle des titans als farbungsursache von blau-und rosenquartz, Z. Krist, p.1-17.

- WEBSTER, R. Gems: Their Sources, Descriptions and Identification. 5aㅡ ed. / revised by Peter G. Read.

- YARDLEY, B. W. D. (1983) - Quartz Veins and Devolatilization During Metamorphism, Geol. Soc. London, vol. 140, p. 657-663.

- ZUSSMAN, J.; HOWIE, A. R.; DEER, A, W. (1966) \& MACEDO, R. A.C. (2000) - Minerais constituintes das Rochas. Fundação Calouste Gulbernkian. Lisboa. 727 p.

- GRATZ, A. J. (1991) - Solution-transfer Compaction of Quartzites: Progress toward a rate law, California, Geology, vol. 19, p. 901-904. 


\section{ANEXO}

Localidades e posições geográficas das ocorrências de quartzo gemológico no Estado da Bahia:

\begin{tabular}{|c|c|c|c|c|c|}
\hline Região & Município & Recurso & Latitude & $\mathrm{H}$ & Longitude \\
\hline RE-05 & Guaratinga & AMETISTA & $16035^{\prime} 05,6^{\prime \prime}$ & $\mathrm{S}$ & 390 59'13,0" \\
\hline RE-05 & Guaratinga & AMETISTA & $16035^{\prime} 31,4^{\prime \prime}$ & $\mathrm{S}$ & 39o $58^{\prime} 45,3^{\prime \prime}$ \\
\hline RE-05 & Itamaraju & AMETISTA & $17001^{\prime} 40,0^{\prime \prime}$ & $\mathrm{S}$ & 39은 '28,0" \\
\hline RE-05 & Itamaraju & AMETISTA & 16 55' 57,9" & $\mathrm{S}$ & $39035^{\prime} 04,6$ " \\
\hline RE-08 & Anagé & AMETISTA & 14은 $44^{\prime} 30,0^{\prime \prime}$ & $\mathrm{S}$ & 41으잉 $40,0^{\prime \prime}$ \\
\hline RE-08 & Anagé & AMETISTA & $14038^{\prime} 29,8^{\prime \prime}$ & $\mathrm{S}$ & $41^{\circ} 05^{\prime} 58,3^{\prime \prime}$ \\
\hline RE-08 & Belo Campo & AMETISTA & $14 \div 58^{\prime} 18,0^{\prime \prime}$ & $\mathrm{S}$ & $41^{\circ} 12^{\prime} 15,0^{\prime \prime}$ \\
\hline RE-08 & Tremedal & AMETISTA & 15으 $03^{\prime} 50,0^{\prime \prime}$ & $\mathrm{S}$ & 41을 $180,0^{\prime \prime}$ \\
\hline RE-08 & Tremedal & AMETISTA & $14{ }^{\circ} 58^{\prime} 38,0^{\prime \prime}$ & $\mathrm{S}$ & $41016^{\prime} 35,0^{\prime \prime}$ \\
\hline RE-08 & Tremedal & AMETISTA & $14051^{\prime} 40,0^{\prime \prime}$ & $\mathrm{S}$ & $41^{\circ} 23^{\prime} 40,0^{\prime \prime}$ \\
\hline RE-08 & Tremedal & AMETISTA & $14 \% 52^{\prime} 02,0^{\prime \prime}$ & $\mathrm{S}$ & 41은 24 ' 19,0 " \\
\hline RE-08 & Vitória da Conquista & AMETISTA & $14 \div 56^{\prime} 02,0^{\prime \prime}$ & $\mathrm{S}$ & 41으임 25,0 " \\
\hline RE-08 & Vitória da Conquista & AMETISTA & $14 \div 52^{\prime} 25,0^{\prime \prime}$ & $\mathrm{S}$ & 41우 $08^{\prime} 00,0^{\prime \prime}$ \\
\hline RE-08 & Vitória da Conquista & AMETISTA & $14054^{\prime} 54,0^{\prime \prime}$ & $\mathrm{S}$ & 41으 $08^{\prime} 01,0^{\prime \prime}$ \\
\hline RE-08 & Vitória da Conquista & AMETISTA & $14052^{\prime} 11,0^{\prime \prime}$ & $\mathrm{S}$ & 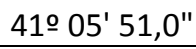 \\
\hline RE-09 & Casa Nova & AMETISTA & 09을' $328,0^{\prime \prime}$ & $\mathrm{S}$ & 41은 $34,37,0^{\prime \prime}$ \\
\hline RE-09 & Casa Nova & AMETISTA & 09 o $10^{\prime} 49,0^{\prime \prime}$ & $\mathrm{S}$ & $41^{\circ} 37^{\prime} 17,0^{\prime \prime}$ \\
\hline RE-09 & Casa Nova & AMETISTA & 09ㅇ 19' 25,0" & $\mathrm{S}$ & $41^{\circ} 14^{\prime} 05,0^{\prime \prime}$ \\
\hline RE-09 & Casa Nova & AMETISTA & 09o 31' 30,3" & $\mathrm{S}$ & $41^{\circ} 37^{\prime} 23,6^{\prime \prime}$ \\
\hline RE-09 & Casa Nova & AMETISTA & 09o 30' 29,1" & $\mathrm{S}$ & $41^{\circ} 28^{\prime} 38,9^{\prime \prime}$ \\
\hline RE-09 & Curaçá & AMETISTA & $08052^{\prime} 12,0^{\prime \prime}$ & $\mathrm{S}$ & $39 \circ 47^{\prime} 44,0^{\prime \prime}$ \\
\hline RE-09 & Curaçá & AMETISTA & 08 o 50' 27,0" & $\mathrm{S}$ & $39035^{\prime} 27,0^{\prime \prime}$ \\
\hline RE-09 & Curaçá & AMETISTA & 08 o 49' 25,0" & $\mathrm{S}$ & $39045^{\prime} 42,0^{\prime \prime}$ \\
\hline RE-09 & Curaçá & AMETISTA & 08우 49' 20,0" & $\mathrm{S}$ & 390 43' $17,7^{\prime \prime}$ \\
\hline RE-09 & Curaçá & AMETISTA & 08 o 50' 53,4" & $\mathrm{S}$ & $39036^{\prime} 10,3^{\prime \prime}$ \\
\hline RE-09 & Curaçá & AMETISTA & 09 o $08^{\prime} 45,2^{\prime \prime}$ & $\mathrm{S}$ & $39050^{\prime} 45,6^{\prime \prime}$ \\
\hline RE-09 & Curaçá & AMETISTA & $08 \div 46^{\prime} 20,0^{\prime \prime}$ & $\mathrm{S}$ & $39035^{\prime} 10,0$ " \\
\hline RE-09 & Juazeiro & AMETISTA & 09o 13' 35,3" & $\mathrm{S}$ & $39055^{\prime} 30,8^{\prime \prime}$ \\
\hline RE-09 & Pilão Arcado & AMETISTA & 09o 50' 19,6" & $\mathrm{S}$ & $42 \circ 34^{\prime} 35,2^{\prime \prime}$ \\
\hline RE-09 & Pilão Arcado & AMETISTA & 09 53 ' 16,0" & $\mathrm{S}$ & $42 \circ 44^{\prime} 01,9 "$ \\
\hline RE-09 & Sento Sé & AMETISTA & 09은 58 ' 15,0" & $\mathrm{S}$ & $41^{\circ} 21^{\prime} 45,0^{\prime \prime}$ \\
\hline RE-09 & Sento Sé & AMETISTA & 09o 33' 18,0" & $\mathrm{S}$ & 41으 $06^{\prime} 30,0^{\prime \prime}$ \\
\hline RE-09 & Sento Sé & AMETISTA & 09o 53' 15,0" & $\mathrm{S}$ & 41이 '45,0" \\
\hline RE-09 & Sento Sé & AMETISTA & 09 o $31^{\prime} 43,8^{\prime \prime}$ & $\mathrm{S}$ & $41^{\circ} 06^{\prime} 45,4^{\prime \prime}$ \\
\hline RE-09 & Sento Sé & AMETISTA & 09 58' 51,7" & $\mathrm{S}$ & $41^{\circ} 20^{\prime} 17,2^{\prime \prime}$ \\
\hline RE-09 & Sento Sé & AMETISTA & 09o 59' 38,5" & $\mathrm{S}$ & $41^{\circ} 20^{\prime} 52,6^{\prime \prime}$ \\
\hline RE-10 & Campo Formoso & AMETISTA & 10 o 21' 30,0" & $\mathrm{S}$ & 41이 $09^{\prime} 30,0$ " \\
\hline RE-10 & Campo Formoso & AMETISTA & 10 o $24^{\prime} 15,4^{\prime \prime}$ & $\mathrm{S}$ & 41으이 05,3 " \\
\hline RE-10 & Jacobina & AMETISTA & 11 o $10^{\prime} 44,6^{\prime \prime}$ & $\mathrm{S}$ & $40028^{\prime} 46,7^{\prime \prime}$ \\
\hline RE-10 & Jacobina & AMETISTA & 11은 11' 02,1" & $\mathrm{S}$ & 40 - $28^{\prime} 44,7^{\prime \prime}$ \\
\hline RE-10 & Jacobina & AMETISTA & 11 o $03^{\prime} 00,4^{\prime \prime}$ & $\mathrm{S}$ & 40 - 32'00,2" \\
\hline RE-10 & Jacobina & AMETISTA & 11 o $03^{\prime} 05,6 "$ & $\mathrm{~S}$ & $40 \circ 33^{\prime} 40,2^{\prime \prime}$ \\
\hline RE-10 & Jacobina & AMETISTA & 11 o $05^{\prime} 00,4^{\prime \prime}$ & $\mathrm{S}$ & 40 $34^{\prime} 00,2^{\prime \prime}$ \\
\hline RE-11 & Barra do Mendes & AMETISTA & $12 \circ 02^{\prime} 00,0^{\prime \prime}$ & $\mathrm{S}$ & $42 \circ 08^{\prime} 30,0^{\prime \prime}$ \\
\hline
\end{tabular}




\begin{tabular}{|c|c|c|c|c|c|}
\hline RE-11 & Barra do Mendes & AMETISTA & $12 \circ 00^{\prime} 37,3^{\prime \prime}$ & $\mathrm{s}$ & $42 \circ 04$ ' $15,7^{\prime \prime}$ \\
\hline RE-11 & Barra do Mendes & AMETISTA & $12^{\circ} 00^{\prime} 16,0^{\prime \prime}$ & $\mathrm{s}$ & $42 \circ 04^{\prime} 15,5^{\prime \prime}$ \\
\hline RE-11 & Barra do Mendes & AMETISTA & $11^{\circ}=58^{\prime} 10,1^{\prime \prime}$ & $\mathrm{S}$ & 42004 ' $57,8^{\prime \prime}$ \\
\hline RE-11 & Barra do Mendes & AMETISTA & $11^{\circ}=58^{\prime} 00,3^{\prime \prime}$ & $\mathrm{S}$ & $42 \circ 05^{\prime} 04,5^{\prime \prime}$ \\
\hline RE-11 & Barra do Mendes & AMETISTA & $12 \circ 00^{\prime} 21,7^{\prime \prime}$ & $\mathrm{S}$ & $42^{\circ} 04^{\prime} 15,3^{\prime \prime}$ \\
\hline RE-11 & Gentio do Ouro & AMETISTA & $11^{\circ} 28^{\prime} 53,0^{\prime \prime}$ & $\mathrm{S}$ & $42^{\circ}=41^{\prime} 07,0^{\prime \prime}$ \\
\hline RE-11 & Gentio do Ouro & AMETISTA & $11^{\circ}=33^{\prime} 06,0^{\prime \prime}$ & $\mathrm{S}$ & $42 \circ 26^{\prime} 43,0^{\prime \prime}$ \\
\hline RE-11 & Gentio do Ouro & AMETISTA & $11^{\circ} 21^{\prime} 40,0^{\prime \prime}$ & $\mathrm{s}$ & $42^{\circ} 36^{\prime} 05,0^{\prime \prime}$ \\
\hline RE-11 & Gentio do Ouro & AMETISTA & $11^{\circ} 28^{\prime} 23,9^{\prime \prime}$ & $\mathrm{S}$ & $42^{\circ} 32^{\prime} 04,3^{\prime \prime}$ \\
\hline RE-11 & Gentio do Ouro & AMETISTA & $11^{\circ} 28^{\prime} 34,6^{\prime \prime}$ & $\mathrm{S}$ & $42^{\circ}=41^{\prime} 16,5^{\prime \prime}$ \\
\hline RE-11 & Gentio do Ouro & AMETISTA & $11027^{\prime} 31,4 "$ & $\mathrm{~S}$ & $42^{\circ} 41^{\prime} 21,6^{\prime \prime}$ \\
\hline RE-11 & Gentio do Ouro & AMETISTA & $11^{\circ} 28^{\prime} 25,4^{\prime \prime}$ & $\mathrm{S}$ & $42^{\circ}=41^{\prime} 14,6^{\prime \prime}$ \\
\hline RE-12 & Boninal & AMETISTA & $12^{\circ}=41^{\prime} 45,0^{\prime \prime}$ & $\mathrm{S}$ & $41046^{\prime} 15,0^{\prime \prime}$ \\
\hline RE-12 & Boquira & AMETISTA & 12 은 53,0" & $\mathrm{s}$ & $42 \circ 38^{\prime} 30,0^{\prime \prime}$ \\
\hline RE-12 & Botuporã & AMETISTA & 13을 21' 40,0" & $\mathrm{S}$ & $42 \circ 27^{\prime} 50,0^{\prime \prime}$ \\
\hline RE-12 & Paramirim & AMETISTA & 13을 $27^{\prime} 05,0^{\prime \prime}$ & $\mathrm{S}$ & $42^{\circ}=19^{\prime} 45,0^{\prime \prime}$ \\
\hline RE-12 & Tanque Novo & AMETISTA & 13으 35' 15,0" & $\mathrm{S}$ & $42^{\circ}=24^{\prime} 46,0^{\prime \prime}$ \\
\hline RE-13 & Brumado & AMETISTA & $14008^{\prime} 10,0^{\prime \prime}$ & $\mathrm{S}$ & 41 은 $43^{\prime} 30,0^{\prime \prime}$ \\
\hline RE-13 & Caculé & AMETISTA & $14024^{\prime} 28,2^{\prime \prime}$ & $\mathrm{S}$ & $42 \circ 27^{\prime} 03,4^{\prime \prime}$ \\
\hline RE-13 & Caculé & AMETISTA & $14^{\circ} 21^{\prime} 55,0^{\prime \prime}$ & $\mathrm{S}$ & $42^{\circ} 24^{\prime} 30,0^{\prime \prime}$ \\
\hline RE-13 & Caetité & AMETISTA & $14016^{\prime} 45,0^{\prime \prime}$ & $\mathrm{s}$ & $42^{\circ} 29^{\prime} 10,0^{\prime \prime}$ \\
\hline RE-13 & Caetité & AMETISTA & 140 15' 42,4" & $\mathrm{S}$ & $42 \circ 31^{\prime} 28,9^{\prime \prime}$ \\
\hline RE-13 & Caetité & AMETISTA & 140 18' 22,0" & $\mathrm{S}$ & $42 \div 29^{\prime} 10,0^{\prime \prime}$ \\
\hline RE-13 & Caetité & AMETISTA & $14015^{\prime} 52,0^{\prime \prime}$ & $\mathrm{S}$ & $42^{\circ} 29^{\prime} 26,0^{\prime \prime}$ \\
\hline RE-13 & Caetité & AMETISTA & 14o 18' 10,0" & $\mathrm{s}$ & $42 \circ 29^{\prime} 45,0^{\prime \prime}$ \\
\hline RE-13 & Caetité & AMETISTA & 140 17' 40,9" & $\mathrm{S}$ & $42^{\circ} 29^{\prime} 32,5^{\prime \prime}$ \\
\hline RE-13 & Caetité & AMETISTA & $14018^{\prime} 12,0^{\prime \prime}$ & $\mathrm{S}$ & $42 \circ 27^{\prime} 35,0^{\prime \prime}$ \\
\hline RE-13 & Caetité & AMETISTA & $14018^{\prime} 00,0^{\prime \prime}$ & $\mathrm{S}$ & $42^{\circ}=28^{\prime} 30,0^{\prime \prime}$ \\
\hline RE-13 & Caetité & AMETISTA & 140 10' 48,0" & $\mathrm{s}$ & $42^{\circ} 24^{\prime} 10,0^{\prime \prime}$ \\
\hline RE-13 & Caetité & AMETISTA & 140 10' 35,0" & $\mathrm{s}$ & $42^{\circ} 28^{\prime} 25,0^{\prime \prime}$ \\
\hline RE-13 & Caetité & AMETISTA & $14015^{\prime} 54,0^{\prime \prime}$ & $\mathrm{S}$ & $42^{\circ}=30^{\prime} 15,0^{\prime \prime}$ \\
\hline RE-13 & Caetité & AMETISTA & $14^{\circ} 17^{\prime} 38,1^{\prime \prime}$ & $\mathrm{S}$ & $42^{\circ}-31^{\prime} 54,9^{\prime \prime}$ \\
\hline RE-13 & Condeúba & AMETISTA & $15008^{\prime} 09,3^{\prime \prime}$ & $\mathrm{s}$ & $42-04^{\prime} 17,7^{\prime \prime}$ \\
\hline RE-13 & Condeúba & AMETISTA & 150 09' 14,4" & $\mathrm{S}$ & $42 \circ 03^{\prime} 49,3^{\prime \prime}$ \\
\hline RE-13 & Condeúba & AMETISTA & $15007^{\prime} 58,1^{\prime \prime}$ & $\mathrm{S}$ & $42^{\circ} 04^{\prime} 56,4^{\prime \prime}$ \\
\hline RE-13 & Condeúba & AMETISTA & 15007 ' 25,6" & $\mathrm{S}$ & $42^{\circ} 04^{\prime} 57,3^{\prime \prime}$ \\
\hline RE-13 & Cordeiros & AMETISTA & $15006^{\prime} 45,0^{\prime \prime}$ & $\mathrm{S}$ & $41^{\circ}=54^{\prime} 27,0^{\prime \prime}$ \\
\hline RE-13 & Cordeiros & AMETISTA & $15003^{\prime} 52,9 "$ & $\mathrm{~S}$ & 41 은 $48^{\prime} 47,9^{\prime \prime}$ \\
\hline RE-13 & Ibiassucê & AMETISTA & $14^{\circ} 11^{\prime} 27,0^{\prime \prime}$ & $\mathrm{S}$ & $42^{\circ} 18^{\prime} 59,0^{\prime \prime}$ \\
\hline RE-13 & Ibiassucê & AMETISTA & 140 14' 03,0" & $\mathrm{s}$ & $42^{\circ} 21^{\prime} 22,0^{\prime \prime}$ \\
\hline RE-13 & Jacaraci & AMETISTA & 140 44' 45,8" & $\mathrm{s}$ & 42 ㅇ $13^{\prime} 58,4^{\prime \prime}$ \\
\hline RE-13 & Jacaraci & AMETISTA & $14047^{\prime} 32,0^{\prime \prime}$ & $\mathrm{s}$ & $42 \circ 28^{\prime} 15,0^{\prime \prime}$ \\
\hline RE-13 & Jacaraci & AMETISTA & $14043^{\prime} 08,7^{\prime \prime}$ & $\mathrm{S}$ & $42^{\circ} 14^{\prime} 28,4^{\prime \prime}$ \\
\hline RE-13 & Lagoa Real & AMETISTA & $14000^{\prime} 49,0^{\prime \prime}$ & $\mathrm{S}$ & $42^{\circ}=11^{\prime} 23,0^{\prime \prime}$ \\
\hline RE-13 & Licínio de Almeida & AMETISTA & $14031^{\prime} 54,4^{\prime \prime}$ & $\mathrm{S}$ & $42^{\circ} 32^{\prime} 02,8^{\prime \prime}$ \\
\hline RE-13 & Licínio de Almeida & AMETISTA & $14034^{\prime} 49,9 "$ & $\mathrm{~S}$ & $42^{\circ} 28^{\prime} 25,7^{\prime \prime}$ \\
\hline RE-13 & Licínio de Almeida & AMETISTA & $14^{\circ} 25^{\prime} 24,7^{\prime \prime}$ & $\mathrm{S}$ & $42^{\circ} 28^{\prime} 03,3^{\prime \prime}$ \\
\hline RE-13 & Licínio de Almeida & AMETISTA & $14032^{\prime} 42,0 "$ & $\mathrm{~s}$ & $42^{\circ} 22^{\prime} 14,0^{\prime \prime}$ \\
\hline RE-13 & Licínio de Almeida & AMETISTA & $14047^{\prime} 41,0^{\prime \prime}$ & $\mathrm{S}$ & $42^{\circ}=32^{\prime} 33,0^{\prime \prime}$ \\
\hline RE-13 & Licínio de Almeida & AMETISTA & $14031^{\prime} 00,0 "$ & $\mathrm{~s}$ & $42 \circ 31^{\prime} 40,0^{\prime \prime}$ \\
\hline
\end{tabular}




\begin{tabular}{|c|c|c|c|c|c|}
\hline RE-13 & Licínio de Almeida & AMETISTA & $14^{\circ} 35^{\prime} 00,0^{\prime \prime}$ & $\mathrm{s}$ & $42 \circ 21^{\prime} 30,0^{\prime \prime}$ \\
\hline RE-13 & Maetinga & AMETISTA & $14032^{\prime} 15,7^{\prime \prime}$ & $\mathrm{S}$ & $41^{\circ}=45^{\prime} 25,2^{\prime \prime}$ \\
\hline RE-13 & Mortugaba & AMETISTA & $14056^{\prime} 11,2^{\prime \prime}$ & $\mathrm{S}$ & $42 \circ 14^{\prime} 35,5^{\prime \prime}$ \\
\hline RE-13 & Pres. Jânio Quadros & AMETISTA & $14046^{\prime} 20,0^{\prime \prime}$ & $\mathrm{S}$ & $41^{\circ}=52^{\prime} 25,0^{\prime \prime}$ \\
\hline RE-09 & Casa Nova & CITRINO & 09ㅇ 04' 59,0" & $\mathrm{S}$ & $41^{\circ} 31^{\prime} 11,8^{\prime \prime}$ \\
\hline RE-10 & Campo Formoso & CITRINO & 10 - 23' 13,4" & $\mathrm{S}$ & $40018^{\prime} 52,1^{\prime \prime}$ \\
\hline RE-11 & Barra do Mendes & CITRINO & $11046^{\prime} 14,1^{\prime \prime}$ & $\mathrm{S}$ & $42 \circ 01^{\prime} 51,7^{\prime \prime}$ \\
\hline RE-11 & Gentio do Ouro & CITRINO & $11^{\circ} 37^{\prime} 18,8^{\prime \prime}$ & $\mathrm{s}$ & $42 \div 37^{\prime} 19,0^{\prime \prime}$ \\
\hline RE-14 & Morporá & CITRINO & 11 $52^{\prime} 50,4^{\prime \prime}$ & $\mathrm{S}$ & $42^{\circ}=52^{\prime} 49,6^{\prime \prime}$ \\
\hline RE-03 & Aratuípe & QUARTZO & 13으 03' 49,4" & $\mathrm{S}$ & $39000^{\prime} 35,7^{\prime \prime}$ \\
\hline RE-03 & Aratuípe & QUARTZO & 13응' $12,6 "$ & $\mathrm{~S}$ & 39000 ' 33,1" \\
\hline RE-03 & Brejões & QUARTZO & $13 \circ 04$ ' 00,0" & $\mathrm{S}$ & $39 \circ 47^{\prime} 15,0^{\prime \prime}$ \\
\hline RE-03 & Brejões & QUARTZO & 13으 02 ' 30,0" & $\mathrm{S}$ & $39 \circ 53^{\prime} 15,0^{\prime \prime}$ \\
\hline RE-03 & Brejões & QUARTZO & $13 \circ 05^{\prime} 45,2^{\prime \prime}$ & $\mathrm{s}$ & $39 \circ 47^{\prime} 10,3^{\prime \prime}$ \\
\hline RE-03 & Cabaceiras do Paraguaçu & QUARTZO & $12035^{\prime} 26,8^{\prime \prime}$ & $\mathrm{S}$ & 390 16' $38,0^{\prime \prime}$ \\
\hline RE-03 & Cabaceiras do Paraguaçu & QUARTZO & $12 \circ 38^{\prime} 23,2^{\prime \prime}$ & $\mathrm{S}$ & $39015^{\prime} 11,5^{\prime \prime}$ \\
\hline RE-03 & Cabaceiras do Paraguaçu & QUARTZO & $12 \circ 35^{\prime} 27,9 "$ & $\mathrm{~S}$ & $39 \circ 16^{\prime} 37,4^{\prime \prime}$ \\
\hline RE-03 & Cachoeira & QUARTZO & $12035^{\prime} 54,2^{\prime \prime}$ & $\mathrm{S}$ & $38056^{\prime} 56,6^{\prime \prime}$ \\
\hline RE-03 & Castro Alves & QUARTZO & $12 \circ 45^{\prime} 25,0^{\prime \prime}$ & $\mathrm{S}$ & 39o $22^{\prime} 50,0^{\prime \prime}$ \\
\hline RE-03 & Castro Alves & QUARTZO & 12 o 43' 50,0" & $\mathrm{S}$ & $39026^{\prime} 15,0^{\prime \prime}$ \\
\hline RE-03 & Castro Alves & QUARTZO & $12^{\circ} 43^{\prime} 57,0^{\prime \prime}$ & $\mathrm{s}$ & $39 \circ 22^{\prime} 16,0^{\prime \prime}$ \\
\hline RE-03 & Castro Alves & QUARTZO & $12 \circ 46^{\prime} 30,0^{\prime \prime}$ & $\mathrm{S}$ & $39027^{\prime} 30,0^{\prime \prime}$ \\
\hline RE-03 & Castro Alves & QUARTZO & $12 \circ 46^{\prime} 35,0^{\prime \prime}$ & $\mathrm{S}$ & $39 \circ 21^{\prime} 01,0^{\prime \prime}$ \\
\hline RE-03 & Castro Alves & QUARTZO & $12 \circ 45^{\prime} 34,0 "$ & $\mathrm{~S}$ & $39 \circ 20^{\prime} 00,0^{\prime \prime}$ \\
\hline RE-03 & Castro Alves & QUARTZO & 12 o 45' 32,0" & $\mathrm{s}$ & $39-22^{\prime} 04,0^{\prime \prime}$ \\
\hline RE-03 & Castro Alves & QUARTZO & $12 \circ 36$ '00,0" & $\mathrm{S}$ & 39o $17^{\prime} 30,0^{\prime \prime}$ \\
\hline RE-03 & Castro Alves & QUARTZO & 12 o 36' 00,0" & $\mathrm{S}$ & 39o $17^{\prime} 30,0^{\prime \prime}$ \\
\hline RE-03 & Castro Alves & QUARTZO & 12 - 43' $30,0^{\prime \prime}$ & $\mathrm{S}$ & $39 \circ 27^{\prime} 15,0^{\prime \prime}$ \\
\hline RE-03 & Castro Alves & QUARTZO & $12^{\circ} 48^{\prime} 00,0^{\prime \prime}$ & $\mathrm{s}$ & $39 \circ 25^{\prime} 50,0^{\prime \prime}$ \\
\hline RE-03 & Castro Alves & QUARTZO & $12049^{\prime} 25,0^{\prime \prime}$ & $\mathrm{S}$ & $39025^{\prime} 40,0^{\prime \prime}$ \\
\hline RE-03 & Castro Alves & QUARTZO & $12 \circ 46^{\prime} 15,0^{\prime \prime}$ & $\mathrm{S}$ & $39 \circ 27^{\prime} 03,0^{\prime \prime}$ \\
\hline RE-03 & Castro Alves & QUARTZO & $12 \circ 48^{\prime} 15,0^{\prime \prime}$ & $\mathrm{S}$ & $39 \circ 25^{\prime} 00,0^{\prime \prime}$ \\
\hline RE-03 & Castro Alves & QUARTZO & $12 \circ 45^{\prime} 55,0^{\prime \prime}$ & $\mathrm{S}$ & $39025^{\prime} 45,0^{\prime \prime}$ \\
\hline RE-03 & Castro Alves & QUARTZO & 12 - $42^{\prime} 15,7^{\prime \prime}$ & $\mathrm{S}$ & $39021^{\prime} 11,2^{\prime \prime}$ \\
\hline RE-03 & Castro Alves & QUARTZO & $12 \circ 46^{\prime} 30,0^{\prime \prime}$ & $\mathrm{S}$ & 39을 $22^{\prime} 50,0^{\prime \prime}$ \\
\hline RE-03 & Castro Alves & QUARTZO & 12 - 46' 30,0" & $\mathrm{S}$ & $39 \circ 22^{\prime} 50,0^{\prime \prime}$ \\
\hline RE-03 & Castro Alves & QUARTZO & $12 \circ 44^{\prime} 15,0^{\prime \prime}$ & $\mathrm{S}$ & 39을 20 '30,0" \\
\hline RE-03 & Castro Alves & QUARTZO & 12 o 43' 50,0" & $\mathrm{S}$ & $39021^{\prime} 03,0^{\prime \prime}$ \\
\hline RE-03 & Castro Alves & QUARTZO & $12 \circ 49^{\prime} 45,0 "$ & $\mathrm{~S}$ & 39o 19' 50,0" \\
\hline RE-03 & Castro Alves & QUARTZO & $12^{\circ} 45^{\prime} 47,3^{\prime \prime}$ & $\mathrm{s}$ & 39o $19^{\prime} 34,8^{\prime \prime}$ \\
\hline RE-03 & Castro Alves & QUARTZO & 12ㅇ 45' 06,9" & $\mathrm{s}$ & 39o 24 ' $33,2^{\prime \prime}$ \\
\hline RE-03 & Castro Alves & QUARTZO & $12043^{\prime} 32,0^{\prime \prime}$ & $\mathrm{S}$ & 39o $23^{\prime} 30,0^{\prime \prime}$ \\
\hline RE-03 & Castro Alves & QUARTZO & $12 \circ 44^{\prime} 50,0^{\prime \prime}$ & $\mathrm{S}$ & 39o $19^{\prime} 50,0^{\prime \prime}$ \\
\hline RE-03 & Castro Alves & QUARTZO & $12 \circ 46^{\prime} 15,0^{\prime \prime}$ & $\mathrm{S}$ & $39029^{\prime} 15,0^{\prime \prime}$ \\
\hline RE-03 & Castro Alves & QUARTZO & $12 \circ 41^{\prime} 55,7^{\prime \prime}$ & $\mathrm{S}$ & 39o $15^{\prime} 05,3^{\prime \prime}$ \\
\hline RE-03 & Castro Alves & QUARTZO & $12 \circ 46$ ' 57,5" & $\mathrm{S}$ & $39023^{\prime} 45,2^{\prime \prime}$ \\
\hline RE-03 & Castro Alves & QUARTZO & $12 \circ 47^{\prime} 28,4^{\prime \prime}$ & $\mathrm{S}$ & 39o $23^{\prime} 50,4^{\prime \prime}$ \\
\hline RE-03 & Castro Alves & QUARTZO & $12^{\circ} 38^{\prime} 11,2^{\prime \prime}$ & $\mathrm{s}$ & $39024^{\prime} 27,4^{\prime \prime}$ \\
\hline RE-03 & Castro Alves & QUARTZO & $12 \circ 36^{\prime} 17,4^{\prime \prime}$ & $\mathrm{S}$ & 39o $21^{\prime} 42,1^{\prime \prime}$ \\
\hline RE-03 & Castro Alves & QUARTZO & 12 o 49' $47,3^{\prime \prime}$ & $\mathrm{s}$ & $39 \circ 24^{\prime} 50,0^{\prime \prime}$ \\
\hline
\end{tabular}




\begin{tabular}{|c|c|c|c|c|c|}
\hline RE-03 & Castro Alves & QUARTZO & $12 \circ 38^{\prime} 42,3^{\prime \prime}$ & $\mathrm{s}$ & 39o $15^{\prime} 03,8^{\prime \prime}$ \\
\hline RE-03 & Castro Alves & QUARTZO & $12 \circ 51^{\prime} 11,8 "$ & $\mathrm{~s}$ & $39025^{\prime} 42,2^{\prime \prime}$ \\
\hline RE-03 & Castro Alves & QUARTZO & 12 잉 $31,0^{\prime \prime}$ & $\mathrm{S}$ & $39025^{\prime} 53,9^{\prime \prime}$ \\
\hline RE-03 & Castro Alves & QUARTZO & 12 일 $17,8^{\prime \prime}$ & $\mathrm{S}$ & 39o $26^{\prime} 37,3^{\prime \prime}$ \\
\hline RE-03 & Conceição do Almeida & QUARTZO & 12056 ' 28,3" & $\mathrm{S}$ & 390 15' 24,9" \\
\hline RE-03 & Laje & QUARTZO & 13 으 $05^{\prime} 30,0 "$ & $\mathrm{~S}$ & $39 \circ 24^{\prime} 45,0^{\prime \prime}$ \\
\hline RE-03 & Maragojipe & QUARTZO & $12046^{\prime} 15,0^{\prime \prime}$ & $\mathrm{S}$ & $38058^{\prime} 58,0^{\prime \prime}$ \\
\hline RE-03 & Milagres & QUARTZO & 12 o 57' 00,0" & $\mathrm{S}$ & 390 57' 40,0" \\
\hline RE-03 & Nova Itarana & QUARTZO & 13으 04' 50,0" & $\mathrm{S}$ & $40 \circ 08^{\prime} 10,9^{\prime \prime}$ \\
\hline RE-03 & Nova Itarana & QUARTZO & 12 은 56' 50,0" & $\mathrm{S}$ & $39056^{\prime} 50,0^{\prime \prime}$ \\
\hline RE-03 & Santa Terezinha & QUARTZO & 12ㅇ 39' 45,0" & $\mathrm{S}$ & $39026^{\prime} 45,0^{\prime \prime}$ \\
\hline RE-03 & Santa Terezinha & QUARTZO & $12 \circ 41^{\prime} 28,0^{\prime \prime}$ & $\mathrm{S}$ & $39 \circ 27^{\prime} 38,0^{\prime \prime}$ \\
\hline RE-03 & Santa Terezinha & QUARTZO & $12 \circ 37^{\prime} 41,0 "$ & $\mathrm{~S}$ & $39036^{\prime} 14,6^{\prime \prime}$ \\
\hline RE-03 & São Félix & QUARTZO & $12 \circ 38^{\prime} 17,2^{\prime \prime}$ & $\mathrm{S}$ & $38058^{\prime} 48,7^{\prime \prime}$ \\
\hline RE-03 & Ubaíra & QUARTZO & 13으 11' 30,0" & $\mathrm{S}$ & 39o $44^{\prime} 30,0^{\prime \prime}$ \\
\hline RE-03 & Ubaíra & QUARTZO & 13 ㅇ $20^{\prime} 00,0 "$ & $\mathrm{~S}$ & $39 \circ 39^{\prime} 00,0^{\prime \prime}$ \\
\hline RE-03 & Ubaíra & QUARTZO & 13으 $18^{\prime} 00,0 "$ & $\mathrm{~S}$ & $39 \circ 43^{\prime} 45,0^{\prime \prime}$ \\
\hline RE-04 & Apuarema & QUARTZO & 13으 48' 45,0" & $\mathrm{S}$ & $39 \circ 45^{\prime} 00,0^{\prime \prime}$ \\
\hline RE-04 & Itamari & QUARTZO & $13 \circ 46^{\prime} 44,0^{\prime \prime}$ & $\mathrm{s}$ & 39o 40' 30,0" \\
\hline RE-04 & Itamari & QUARTZO & $13 \circ 48^{\prime} 43,0 "$ & $\mathrm{~S}$ & $39 \circ 41^{\prime} 03,0^{\prime \prime}$ \\
\hline RE-04 & Itamari & QUARTZO & 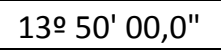 & $\mathrm{S}$ & $39 \circ 40^{\prime} 30,0^{\prime \prime}$ \\
\hline RE-04 & Nilo Peçanha & QUARTZO & 13으 41' 45,0" & $\mathrm{S}$ & 39ㅇ $22^{\prime} 04,0^{\prime \prime}$ \\
\hline RE-04 & Nova Ibiá & QUARTZO & 13 50' 00,0" & $\mathrm{S}$ & $39 \circ 40^{\prime} 30,0^{\prime \prime}$ \\
\hline RE-04 & Pau Brasil & QUARTZO & $15 \circ 32^{\prime} 02,0 "$ & $\mathrm{~S}$ & $39039^{\prime} 13,0^{\prime \prime}$ \\
\hline RE-05 & Belmonte & QUARTZO & 15 o 50' $42,3^{\prime \prime}$ & $\mathrm{S}$ & $39 \circ 23^{\prime} 37,5^{\prime \prime}$ \\
\hline RE-05 & Guaratinga & QUARTZO & $16035^{\prime} 08,8^{\prime \prime}$ & $\mathrm{S}$ & 39o $47^{\prime} 18,0^{\prime \prime}$ \\
\hline RE-05 & Guaratinga & QUARTZO & $16031^{\prime} 08,0 "$ & $\mathrm{~S}$ & 390 45' 39,0" \\
\hline RE-05 & Guaratinga & QUARTZO & $16028^{\prime} 32,0^{\prime \prime}$ & $\mathrm{S}$ & $39 \circ 51^{\prime} 35,0^{\prime \prime}$ \\
\hline RE-05 & Guaratinga & QUARTZO & 16o $16^{\prime} 04,0 "$ & $\mathrm{~S}$ & $39 \circ 54^{\prime} 41,0^{\prime \prime}$ \\
\hline RE-05 & Guaratinga & QUARTZO & $16021^{\prime} 48,0^{\prime \prime}$ & $\mathrm{S}$ & 390 55' 20,3" \\
\hline RE-05 & Guaratinga & QUARTZO & $16031^{\prime} 00,0 "$ & $\mathrm{~S}$ & $40007^{\prime} 35,0^{\prime \prime}$ \\
\hline RE-05 & Guaratinga & QUARTZO & $16040^{\prime} 15,0 "$ & $\mathrm{~S}$ & $40013^{\prime} 35,0^{\prime \prime}$ \\
\hline RE-05 & Guaratinga & QUARTZO & $16033^{\prime} 20,0 "$ & $\mathrm{~S}$ & $40 \circ 02^{\prime} 05,0^{\prime \prime}$ \\
\hline RE-05 & Guaratinga & QUARTZO & $16037^{\prime} 45,0 "$ & $\mathrm{~S}$ & $40008^{\prime} 40,0^{\prime \prime}$ \\
\hline RE-05 & Guaratinga & QUARTZO & $16033^{\prime} 30,8^{\prime \prime}$ & $\mathrm{S}$ & $39041^{\prime} 26,8^{\prime \prime}$ \\
\hline RE-05 & Guaratinga & QUARTZO & $16039^{\prime} 37,8^{\prime \prime}$ & $\mathrm{S}$ & $39 \circ 45^{\prime} 05,8^{\prime \prime}$ \\
\hline RE-05 & Guaratinga & QUARTZO & $16038^{\prime} 23,0^{\prime \prime}$ & $\mathrm{s}$ & 39ㅇ $44^{\prime} 53,7^{\prime \prime}$ \\
\hline RE-05 & Itabela & QUARTZO & 16 o 30' 57,7" & $\mathrm{S}$ & 39 o $33^{\prime} 13,7^{\prime \prime}$ \\
\hline RE-05 & Itabela & QUARTZO & $16032^{\prime} 49,8^{\prime \prime}$ & $\mathrm{S}$ & 39034 '09,7" \\
\hline RE-05 & Itagimirim & QUARTZO & $16000^{\prime} 31,5^{\prime \prime}$ & $\mathrm{s}$ & $39046^{\prime} 39,8^{\prime \prime}$ \\
\hline RE-05 & Itagimirim & QUARTZO & 16 05' 31,3" & $\mathrm{s}$ & 39034 ' 10,0" \\
\hline RE-05 & Itagimirim & QUARTZO & $16005^{\prime} 00,9 "$ & $\mathrm{~s}$ & $39038^{\prime} 52,9^{\prime \prime}$ \\
\hline RE-05 & Itagimirim & QUARTZO & $16001^{\prime} 10,7^{\prime \prime}$ & $\mathrm{S}$ & $39 \circ 44^{\prime} 01,7^{\prime \prime}$ \\
\hline RE-05 & Itamaraju & QUARTZO & $16052^{\prime} 19,0 "$ & $\mathrm{~S}$ & $39 \circ 36^{\prime} 54,0^{\prime \prime}$ \\
\hline RE-05 & Itamaraju & QUARTZO & $16048^{\prime} 47,0^{\prime \prime}$ & $\mathrm{s}$ & $39 \circ 40^{\prime} 46,1^{\prime \prime}$ \\
\hline RE-05 & Itamaraju & QUARTZO & 160 59' 39,2" & $\mathrm{S}$ & 39o 32 '39,9" \\
\hline RE-05 & Itamaraju & QUARTZO & $16053^{\prime} 55,0 "$ & $\mathrm{~S}$ & $39 \circ 50$ ' 55,0" \\
\hline RE-05 & Itamaraju & QUARTZO & $16058^{\prime} 25,0 "$ & $\mathrm{~S}$ & $39 \circ 44^{\prime} 10,0^{\prime \prime}$ \\
\hline RE-05 & Jucuruçu & QUARTZO & 16 o 50' 58,0" & $\mathrm{S}$ & 39o 59' 11,0" \\
\hline RE-05 & Medeiros Neto & QUARTZO & 17o 17' 41,8" & $\mathrm{s}$ & $40 \circ 21^{\prime} 26,2^{\prime \prime}$ \\
\hline
\end{tabular}




\begin{tabular}{|c|c|c|c|c|c|}
\hline RE-05 & Porto Seguro & QUARTZO & $16030^{\prime} 17,0^{\prime \prime}$ & $\mathrm{s}$ & $39 \circ 30^{\prime} 40,0^{\prime \prime}$ \\
\hline RE-05 & Porto Seguro & QUARTZO & $16053^{\prime} 15,0^{\prime \prime}$ & $\mathrm{s}$ & $39006^{\prime} 59,0^{\prime \prime}$ \\
\hline RE-05 & Vereda & QUARTZO & 17o 10' 05,0" & $\mathrm{S}$ & $40008^{\prime} 45,0^{\prime \prime}$ \\
\hline RE-06 & Paripiranga & QUARTZO & 10 o 39' $28,6^{\prime \prime}$ & $\mathrm{S}$ & $37057^{\prime} 29,9^{\prime \prime}$ \\
\hline RE-07 & Baixa Grande & QUARTZO & $12 \circ 00^{\prime} 15,5^{\prime \prime}$ & $\mathrm{S}$ & $40 \circ 09^{\prime} 49,7^{\prime \prime}$ \\
\hline RE-07 & Baixa Grande & QUARTZO & $12 \circ 01^{\prime} 12,4 "$ & $\mathrm{~S}$ & $40003^{\prime} 19,8^{\prime \prime}$ \\
\hline RE-07 & Baixa Grande & QUARTZO & $11055^{\prime} 46,3^{\prime \prime}$ & $\mathrm{N}$ & $40006^{\prime} 49,5^{\prime \prime}$ \\
\hline RE-07 & Baixa Grande & QUARTZO & $11^{\circ} 56^{\prime} 29,6 "$ & $\mathrm{~N}$ & $40 \circ 08^{\prime} 30,3^{\prime \prime}$ \\
\hline RE-07 & Baixa Grande & QUARTZO & $11054^{\prime} 45,5^{\prime \prime}$ & $\mathrm{N}$ & $40 \circ 14^{\prime} 59,0^{\prime \prime}$ \\
\hline RE-07 & Baixa Grande & QUARTZO & 11은 54' 59,9" & $\mathrm{N}$ & $40 \circ 11^{\prime} 42,3^{\prime \prime}$ \\
\hline RE-07 & Baixa Grande & QUARTZO & $12 \circ 02^{\prime} 43,9 "$ & $\mathrm{~N}$ & $40003^{\prime} 55,4^{\prime \prime}$ \\
\hline RE-07 & Baixa Grande & QUARTZO & 12 o 00 ' 30,0" & $\mathrm{S}$ & $40005^{\prime} 15,0^{\prime \prime}$ \\
\hline RE-07 & Baixa Grande & QUARTZO & 11 $56^{\prime} 20,0 "$ & $\mathrm{~S}$ & $40 \circ 08^{\prime} 10,0^{\prime \prime}$ \\
\hline RE-07 & Candeal & QUARTZO & $11^{\circ}=47^{\prime} 22,0^{\prime \prime}$ & $\mathrm{s}$ & $39007^{\prime} 46,9^{\prime \prime}$ \\
\hline RE-07 & Capela do Alto Alegre & QUARTZO & $11^{\circ}-42^{\prime} 00,2^{\prime \prime}$ & $\mathrm{S}$ & $39045^{\prime} 28,5^{\prime \prime}$ \\
\hline RE-07 & Capela do Alto Alegre & QUARTZO & $11^{\circ} 43^{\prime} 47,0^{\prime \prime}$ & $\mathrm{s}$ & $39 \circ 49^{\prime} 30,0^{\prime \prime}$ \\
\hline RE-07 & Capela do Alto Alegre & QUARTZO & 11 은 $46^{\prime} 03,8^{\prime \prime}$ & $\mathrm{S}$ & $39 \circ 48^{\prime} 44,1^{\prime \prime}$ \\
\hline RE-07 & Gavião & QUARTZO & 11 o 30' 30,0" & $\mathrm{S}$ & 39 은 $49^{\prime} 27,0^{\prime \prime}$ \\
\hline RE-07 & Iaçu & QUARTZO & 12 은 $47^{\prime} 16,0^{\prime \prime}$ & $\mathrm{S}$ & $39057^{\prime} 05,6^{\prime \prime}$ \\
\hline RE-07 & Iaçu & QUARTZO & 12 o 40' 30,4" & $\mathrm{S}$ & $40006^{\prime} 23,4^{\prime \prime}$ \\
\hline RE-07 & Iaçu & QUARTZO & $12 \circ 45^{\prime} 55,5^{\prime \prime}$ & $\mathrm{s}$ & $39 \circ 58^{\prime} 50,0^{\prime \prime}$ \\
\hline RE-07 & Iaçu & QUARTZO & 12 o 54' 03,9" & $\mathrm{S}$ & 40 05' $33,8^{\prime \prime}$ \\
\hline RE-07 & Iaçu & QUARTZO & $12 \circ 46^{\prime} 00,0^{\prime \prime}$ & $\mathrm{S}$ & 390 59' 15,0" \\
\hline RE-07 & Iaçu & QUARTZO & $12 \circ 54$ ' 15,0" & $\mathrm{S}$ & $40 \circ 03^{\prime} 15,0^{\prime \prime}$ \\
\hline RE-07 & Iaçu & QUARTZO & 12 o 45' 05,0" & $\mathrm{s}$ & $39 \circ 55^{\prime} 20,0^{\prime \prime}$ \\
\hline RE-07 & Ibiquera & QUARTZO & $12 \circ 36^{\prime} 31,3 "$ & $\mathrm{~s}$ & $40 \circ 53^{\prime} 00,6^{\prime \prime}$ \\
\hline RE-07 & Ipirá & QUARTZO & 12 o $09^{\prime} 18,3 "$ & $\mathrm{~S}$ & 39 o 59' 16,9" \\
\hline RE-07 & Ipirá & QUARTZO & $12 \circ 04^{\prime} 50,0^{\prime \prime}$ & $\mathrm{S}$ & $39 \circ 58^{\prime} 50,0^{\prime \prime}$ \\
\hline RE-07 & Itaberaba & QUARTZO & $12^{\circ} 23^{\prime} 57,8^{\prime \prime}$ & $\mathrm{s}$ & $40 \circ 10^{\prime} 19,2^{\prime \prime}$ \\
\hline RE-07 & Itaberaba & QUARTZO & $12045^{\prime} 12,0^{\prime \prime}$ & $\mathrm{S}$ & 40 일 $46,4^{\prime \prime}$ \\
\hline RE-07 & Itaberaba & QUARTZO & $12 \circ 26^{\prime} 14,6^{\prime \prime}$ & $\mathrm{S}$ & $40021^{\prime} 45,3^{\prime \prime}$ \\
\hline RE-07 & Itaberaba & QUARTZO & $12^{\circ} 28^{\prime} 46,6^{\prime \prime}$ & $\mathrm{N}$ & $40 \circ 02^{\prime} 23,3^{\prime \prime}$ \\
\hline RE-07 & Itaberaba & QUARTZO & 12 o $23^{\prime} 03,8^{\prime \prime}$ & $\mathrm{N}$ & 40 -28'03,4" \\
\hline RE-07 & Itaberaba & QUARTZO & 12 o $28^{\prime} 00,1^{\prime \prime}$ & $\mathrm{N}$ & $40027^{\prime} 43,5^{\prime \prime}$ \\
\hline RE-07 & Itaberaba & QUARTZO & 12 - 23' 05,0" & $\mathrm{S}$ & $40028^{\prime} 05,0^{\prime \prime}$ \\
\hline RE-07 & Itaberaba & QUARTZO & 12 o 21' 45,0" & $\mathrm{s}$ & $40 \circ 12^{\prime} 15,0^{\prime \prime}$ \\
\hline RE-07 & Mundo Novo & QUARTZO & 11 언 $50,8 "$ & $\mathrm{~S}$ & $40021^{\prime} 14,4^{\prime \prime}$ \\
\hline RE-07 & Mundo Novo & QUARTZO & 11 o 49' $24,3 "$ & $\mathrm{~S}$ & $40022^{\prime} 50,1^{\prime \prime}$ \\
\hline RE-07 & Pé de Serra & QUARTZO & $11^{\circ} 52^{\prime} 00,0^{\prime \prime}$ & $\mathrm{S}$ & $39043^{\prime} 15,0^{\prime \prime}$ \\
\hline RE-07 & Pé de Serra & QUARTZO & $11047^{\prime} 17,4^{\prime \prime}$ & $\mathrm{s}$ & $39035^{\prime} 37,9^{\prime \prime}$ \\
\hline RE-07 & Pé de Serra & QUARTZO & 11 o 48'00,9" & $\mathrm{s}$ & $39035^{\prime} 56,2^{\prime \prime}$ \\
\hline RE-07 & Pé de Serra & QUARTZO & $11^{\circ}=47^{\prime} 44,0^{\prime \prime}$ & $\mathrm{S}$ & $39035^{\prime} 23,3^{\prime \prime}$ \\
\hline RE-07 & Pé de Serra & QUARTZO & 11ㅇ4ㅇ 49,7" & $\mathrm{S}$ & $39039^{\prime} 29,6^{\prime \prime}$ \\
\hline RE-07 & Piritiba & QUARTZO & $11^{\circ} 38^{\prime} 05,0^{\prime \prime}$ & $\mathrm{S}$ & $40030^{\prime} 55,0^{\prime \prime}$ \\
\hline RE-07 & Rafael Jambeiro & QUARTZO & 12 o $32^{\prime} 50,0^{\prime \prime}$ & $\mathrm{S}$ & 39o 30' 30,0" \\
\hline RE-07 & Riachão do Jacuípe & QUARTZO & 11 o $37^{\prime} 06,1^{\prime \prime}$ & $\mathrm{s}$ & $39 \circ 31^{\prime} 00,2^{\prime \prime}$ \\
\hline RE-08 & Anagé & QUARTZO & $14046^{\prime} 02,0^{\prime \prime}$ & $\mathrm{S}$ & $41900^{\prime} 50,0^{\prime \prime}$ \\
\hline RE-08 & Anagé & QUARTZO & 14 o $30^{\prime} 36,8^{\prime \prime}$ & $\mathrm{s}$ & $41^{\circ} 044^{\prime} 04,7^{\prime \prime}$ \\
\hline RE-08 & Belo Campo & QUARTZO & $14046^{\prime} 58,0^{\prime \prime}$ & $\mathrm{S}$ & $41^{\circ}=14^{\prime} 05,0^{\prime \prime}$ \\
\hline RE-08 & Belo Campo & QUARTZO & 140 45' 24,0" & $\mathrm{s}$ & 41 일 $13^{\prime} 36,0^{\prime \prime}$ \\
\hline
\end{tabular}




\begin{tabular}{|c|c|c|c|c|c|}
\hline RE-08 & Belo Campo & QUARTZO & $15 \circ 05^{\prime} 10,0^{\prime \prime}$ & $\mathrm{s}$ & $41016^{\prime} 10,0^{\prime \prime}$ \\
\hline RE-08 & Boa Nova & QUARTZO & 14ㅇ 19' 15,0" & $\mathrm{s}$ & $40 \circ 16^{\prime} 40,0^{\prime \prime}$ \\
\hline RE-08 & Caatiba & QUARTZO & 140 57' 58,0" & $\mathrm{S}$ & $40008^{\prime} 25,0^{\prime \prime}$ \\
\hline RE-08 & Caatiba & QUARTZO & 14 o $58^{\prime} 10,0^{\prime \prime}$ & $\mathrm{S}$ & $40007^{\prime} 50,0^{\prime \prime}$ \\
\hline RE-08 & Cândido Sales & QUARTZO & 15 o 24' 20,0" & $\mathrm{S}$ & $41^{\circ} 26^{\prime} 55,0^{\prime \prime}$ \\
\hline RE-08 & Irajuba & QUARTZO & 13으 $15^{\prime} 45,0 "$ & $\mathrm{~S}$ & $39 \circ 56^{\prime} 45,0^{\prime \prime}$ \\
\hline RE-08 & Itaquara & QUARTZO & 13ㅇ 23' 00,0" & $\mathrm{S}$ & 39o 58' 35,0" \\
\hline RE-08 & Itaquara & QUARTZO & 13을 $21^{\prime} 09,0 "$ & $\mathrm{~S}$ & 390 57' $13,0^{\prime \prime}$ \\
\hline RE-08 & Itaquara & QUARTZO & 13 ㅇ $20^{\prime} 00,0 "$ & $\mathrm{~S}$ & $39 \circ 58^{\prime} 45,0^{\prime \prime}$ \\
\hline RE-08 & Jaguaquara & QUARTZO & 13ㅇ $38^{\prime} 35,0^{\prime \prime}$ & $\mathrm{S}$ & $39 \circ 59^{\prime} 10,0^{\prime \prime}$ \\
\hline RE-08 & Jaguaquara & QUARTZO & 13 19' 40,0" & $\mathrm{S}$ & 40 잉 $45,0^{\prime \prime}$ \\
\hline RE-08 & Jaguaquara & QUARTZO & $13035^{\prime} 32,0 "$ & $\mathrm{~S}$ & $39 \circ 50^{\prime} 20,7^{\prime \prime}$ \\
\hline RE-08 & Jaguaquara & QUARTZO & $13036^{\prime} 11,2^{\prime \prime}$ & $\mathrm{S}$ & $39 \circ 51^{\prime} 07,3^{\prime \prime}$ \\
\hline RE-08 & Jequié & QUARTZO & 13ㅇ 55' 00,0" & $\mathrm{s}$ & $40=10^{\prime} 50,0^{\prime \prime}$ \\
\hline RE-08 & Jequié & QUARTZO & 13 o 40' 12,4" & $\mathrm{S}$ & 39 o $58^{\prime} 01,8^{\prime \prime}$ \\
\hline RE-08 & Macarani & QUARTZO & $15 \circ 40$ ' $00,0^{\prime \prime}$ & $\mathrm{s}$ & $40 \circ 22^{\prime} 40,0^{\prime \prime}$ \\
\hline RE-08 & Macarani & QUARTZO & 15 ㅇ $24^{\prime} 25,0^{\prime \prime}$ & $\mathrm{S}$ & $40 \circ 26^{\prime} 51,0^{\prime \prime}$ \\
\hline RE-08 & Macarani & QUARTZO & 15o 44' 31,0" & $\mathrm{s}$ & 40 이 $31^{\prime} 13,0^{\prime \prime}$ \\
\hline RE-08 & Manoel Vitorino & QUARTZO & 140 11' 42,0" & $\mathrm{S}$ & $40918^{\prime} 04,0^{\prime \prime}$ \\
\hline RE-08 & Manoel Vitorino & QUARTZO & 14 o $09^{\prime} 45,0 "$ & $\mathrm{~S}$ & $40039^{\prime} 55,0^{\prime \prime}$ \\
\hline RE-08 & Manoel Vitorino & QUARTZO & $14001^{\prime} 25,0^{\prime \prime}$ & $\mathrm{s}$ & $40 \circ 34^{\prime} 40,0^{\prime \prime}$ \\
\hline RE-08 & Manoel Vitorino & QUARTZO & 14응' $048,0 "$ & $\mathrm{~S}$ & $40 \circ 35^{\prime} 15,0^{\prime \prime}$ \\
\hline RE-08 & Mirante & QUARTZO & 140 12' 40,0" & $\mathrm{S}$ & 40 - $42^{\prime} 10,0^{\prime \prime}$ \\
\hline RE-08 & Tremedal & QUARTZO & $15 \circ 05^{\prime} 05,0 "$ & $\mathrm{~S}$ & $41018^{\prime} 35,0^{\prime \prime}$ \\
\hline RE-08 & Tremedal & QUARTZO & 14 o 50' $25,0^{\prime \prime}$ & $\mathrm{S}$ & $41^{\circ} 21^{\prime} 45,0^{\prime \prime}$ \\
\hline RE-08 & Tremedal & QUARTZO & 140 59' $35,0 "$ & $\mathrm{~S}$ & $41021^{\prime} 50,0^{\prime \prime}$ \\
\hline RE-08 & Tremedal & QUARTZO & 140 55' 09,0" & $\mathrm{S}$ & $41^{\circ} 24^{\prime} 20,0^{\prime \prime}$ \\
\hline RE-08 & Tremedal & QUARTZO & 15 ㅇ 04 ' $01,8 "$ & $\mathrm{~S}$ & $41^{\circ} 21^{\prime} 13,9^{\prime \prime}$ \\
\hline RE-08 & Vitória da Conquista & QUARTZO & $14057^{\prime} 40,0 "$ & $\mathrm{~S}$ & $41^{\circ} 07^{\prime} 45,0^{\prime \prime}$ \\
\hline RE-08 & Vitória da Conquista & QUARTZO & $14 \div 51^{\prime} 30,0^{\prime \prime}$ & $\mathrm{s}$ & $41^{\circ} 02^{\prime} 05,0^{\prime \prime}$ \\
\hline RE-08 & Vitória da Conquista & QUARTZO & $14056^{\prime} 38,9^{\prime \prime}$ & $\mathrm{S}$ & $41^{\circ} 08^{\prime} 16,6^{\prime \prime}$ \\
\hline RE-09 & Campo Alegre de Lourdes & QUARTZO & 09o 31' 50,9" & $\mathrm{S}$ & $43^{\circ} 17^{\prime} 46,8^{\prime \prime}$ \\
\hline RE-09 & Campo Alegre de Lourdes & QUARTZO & $09033^{\prime} 11,5^{\prime \prime}$ & $\mathrm{s}$ & $43-15^{\prime} 18,8^{\prime \prime}$ \\
\hline RE-09 & Casa Nova & QUARTZO & 09o 16' 54,8" & $\mathrm{S}$ & $41^{\circ} 28^{\prime} 20,9^{\prime \prime}$ \\
\hline RE-09 & Casa Nova & QUARTZO & 090 16' 39,5" & $\mathrm{S}$ & $41^{\circ} 28^{\prime} 21,7^{\prime \prime}$ \\
\hline RE-09 & Casa Nova & QUARTZO & 09으 16' 51,3" & $\mathrm{S}$ & $41^{\circ} 28^{\prime} 42,0^{\prime \prime}$ \\
\hline RE-09 & Casa Nova & QUARTZO & 09 05' 05,0" & $\mathrm{s}$ & 41 은 $30^{\prime} 52,0^{\prime \prime}$ \\
\hline RE-09 & Curaçá & QUARTZO & 08 o 59' 05,0" & $\mathrm{S}$ & $39098^{\prime} 36,0^{\prime \prime}$ \\
\hline RE-09 & Curaçá & QUARTZO & $08057^{\prime} 45,0 "$ & $\mathrm{~S}$ & $39 \circ 36^{\prime} 24,0^{\prime \prime}$ \\
\hline RE-09 & Curaçá & QUARTZO & 09 38 '07,0" & $\mathrm{s}$ & $39 \circ 42^{\prime} 50,0^{\prime \prime}$ \\
\hline RE-09 & Curaçá & QUARTZO & 09o 19' 36,2" & $\mathrm{s}$ & 39ㅇ 43' 05,5" \\
\hline RE-09 & Curaçá & QUARTZO & 08 o 50' 38,5" & $\mathrm{S}$ & $39036^{\prime} 08,2^{\prime \prime}$ \\
\hline RE-09 & Curaçá & QUARTZO & 08 55' 19,1" & $\mathrm{S}$ & $39040^{\prime} 16,3^{\prime \prime}$ \\
\hline RE-09 & Juazeiro & QUARTZO & 09은 42' 46,0" & $\mathrm{S}$ & $40041^{\prime} 35,0^{\prime \prime}$ \\
\hline RE-09 & Juazeiro & QUARTZO & 09o 43' 51,7" & $\mathrm{S}$ & $40044^{\prime} 42,8^{\prime \prime}$ \\
\hline RE-09 & Juazeiro & QUARTZO & 09우 47' 20,5" & $\mathrm{S}$ & $40003^{\prime} 17,7^{\prime \prime}$ \\
\hline RE-09 & Juazeiro & QUARTZO & 09o 11' 20,8" & $\mathrm{S}$ & $40007^{\prime} 16,4^{\prime \prime}$ \\
\hline RE-09 & Sento Sé & QUARTZO & $10 \circ 23^{\prime} 35,0^{\prime \prime}$ & $\mathrm{s}$ & $41^{\circ} 32^{\prime} 46,0^{\prime \prime}$ \\
\hline RE-09 & Sento Sé & QUARTZO & 10 o $15^{\prime} 48,0^{\prime \prime}$ & $\mathrm{S}$ & 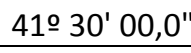 \\
\hline RE-09 & Sento Sé & QUARTZO & 100 15' 00,0" & $\mathrm{s}$ & $41^{\circ} 25^{\prime} 00,0^{\prime \prime}$ \\
\hline
\end{tabular}




\begin{tabular}{|c|c|c|c|c|c|}
\hline RE-09 & Sento Sé & QUARTZO & 10 o $17^{\prime} 15,0^{\prime \prime}$ & $\mathrm{s}$ & $41030^{\prime} 45,0^{\prime \prime}$ \\
\hline RE-09 & Sento Sé & QUARTZO & 10ㅇ $19^{\prime} 47,0^{\prime \prime}$ & $\mathrm{s}$ & $41^{\circ}=32^{\prime} 21,0^{\prime \prime}$ \\
\hline RE-09 & Sento Sé & QUARTZO & $10009^{\prime} 40,0^{\prime \prime}$ & $\mathrm{S}$ & $41024^{\prime} 10,0^{\prime \prime}$ \\
\hline RE-09 & Sento Sé & QUARTZO & $10=20^{\prime} 40,0^{\prime \prime}$ & $\mathrm{S}$ & $41024^{\prime} 35,0^{\prime \prime}$ \\
\hline RE-09 & Sento Sé & QUARTZO & $10=20^{\prime} 55,0 "$ & $\mathrm{~S}$ & $41^{\circ} 23^{\prime} 45,0^{\prime \prime}$ \\
\hline RE-09 & Sento Sé & QUARTZO & $09 \circ 56^{\prime} 00,0^{\prime \prime}$ & $\mathrm{S}$ & $41^{\circ}=15^{\prime} 00,0^{\prime \prime}$ \\
\hline RE-09 & Sento Sé & QUARTZO & 09o $58^{\prime} 15,0^{\prime \prime}$ & $\mathrm{S}$ & $41^{\circ}=21^{\prime} 45,0^{\prime \prime}$ \\
\hline RE-09 & Sento Sé & QUARTZO & 09 $56^{\prime} 56,6^{\prime \prime}$ & $\mathrm{S}$ & $41^{\circ} 21^{\prime} 26,0^{\prime \prime}$ \\
\hline RE-09 & Sento Sé & QUARTZO & $10=25^{\prime} 04,0 "$ & $\mathrm{~s}$ & 41 을 23 '35,0" \\
\hline RE-09 & Sento Sé & QUARTZO & 10o 19' 19,5" & $\mathrm{S}$ & $41^{\circ}=18^{\prime} 20,3^{\prime \prime}$ \\
\hline RE-09 & Sento Sé & QUARTZO & 100 15' 31,4" & $\mathrm{S}$ & $41^{\circ} 26^{\prime} 30,8^{\prime \prime}$ \\
\hline RE-10 & Andorinha & QUARTZO & 10 -19'20,0" & $\mathrm{S}$ & $39055^{\prime} 50,0^{\prime \prime}$ \\
\hline RE-10 & Andorinha & QUARTZO & $10^{\circ} 11^{\prime} 27,6^{\prime \prime}$ & $\mathrm{S}$ & $39 \circ 57^{\prime} 45,4^{\prime \prime}$ \\
\hline RE-10 & Campo Formoso & QUARTZO & $10006^{\prime} 23,0^{\prime \prime}$ & $\mathrm{S}$ & $40 \circ 54^{\prime} 49,0^{\prime \prime}$ \\
\hline RE-10 & Campo Formoso & QUARTZO & $10=02^{\prime} 34,0^{\prime \prime}$ & $\mathrm{S}$ & $40 \circ 57^{\prime} 48,0^{\prime \prime}$ \\
\hline RE-10 & Campo Formoso & QUARTZO & $10=10^{\prime} 22,0^{\prime \prime}$ & $\mathrm{s}$ & 40 - 58' 57,0" \\
\hline RE-10 & Campo Formoso & QUARTZO & $09057^{\prime} 49,0^{\prime \prime}$ & $\mathrm{S}$ & $40 \circ 35^{\prime} 59,0^{\prime \prime}$ \\
\hline RE-10 & Campo Formoso & QUARTZO & $10 \circ 22^{\prime} 01,9^{\prime \prime}$ & $\mathrm{S}$ & $40 \circ 33^{\prime} 05,4^{\prime \prime}$ \\
\hline RE-10 & Capim Grosso & QUARTZO & $11^{\circ} 21^{\prime} 20,0^{\prime \prime}$ & $\mathrm{S}$ & 39o 59'00,0" \\
\hline RE-10 & Capim Grosso & QUARTZO & 11잉 $16^{\prime} 36,0^{\prime \prime}$ & $\mathrm{s}$ & $39 \circ 57^{\prime} 32,7^{\prime \prime}$ \\
\hline RE-10 & Capim Grosso & QUARTZO & 110 $13^{\prime} 44,1^{\prime \prime}$ & $\mathrm{S}$ & $39059^{\prime} 52,1^{\prime \prime}$ \\
\hline $\mathrm{RE}-10$ & Capim Grosso & QUARTZO & $11^{\circ} 22^{\prime} 29,4^{\prime \prime}$ & $\mathrm{S}$ & $39 \circ 58^{\prime} 15,0^{\prime \prime}$ \\
\hline RE-10 & Capim Grosso & QUARTZO & 11을 32 '39,1" & $\mathrm{S}$ & $39058^{\prime} 17,2^{\prime \prime}$ \\
\hline RE-10 & Filadélfia & QUARTZO & $10038^{\prime} 33,1^{\prime \prime}$ & $\mathrm{S}$ & $40 \circ 13^{\prime} 05,1^{\prime \prime}$ \\
\hline RE-10 & Filadélfia & QUARTZO & $10 \circ 39^{\prime} 45,5^{\prime \prime}$ & $\mathrm{S}$ & $40 \circ 14^{\prime} 22,0^{\prime \prime}$ \\
\hline RE-10 & Itiúba & QUARTZO & $10 \circ 44^{\prime} 50,0^{\prime \prime}$ & $\mathrm{S}$ & 39o $44^{\prime} 00,0^{\prime \prime}$ \\
\hline RE-10 & Itiúba & QUARTZO & $10030^{\prime} 55,3^{\prime \prime}$ & $\mathrm{S}$ & 39o 47'09,9" \\
\hline RE-10 & Itiúba & QUARTZO & 10 o $50^{\prime} 15,1^{\prime \prime}$ & $\mathrm{s}$ & $39056^{\prime} 15,4^{\prime \prime}$ \\
\hline RE-10 & Jacobina & QUARTZO & 11을 $12^{\prime} 30,4^{\prime \prime}$ & $\mathrm{S}$ & $40 \circ 29^{\prime} 20,2^{\prime \prime}$ \\
\hline RE-10 & Jaguarari & QUARTZO & 10 o $11^{\prime} 03,0^{\prime \prime}$ & $\mathrm{s}$ & 40 응 $30,0^{\prime \prime}$ \\
\hline RE-10 & Jaguarari & QUARTZO & $10=03^{\prime} 00,0^{\prime \prime}$ & $\mathrm{S}$ & $40007^{\prime} 41,0^{\prime \prime}$ \\
\hline RE-10 & Jaguarari & QUARTZO & $10 \circ 07^{\prime} 00,0^{\prime \prime}$ & $\mathrm{s}$ & $39056^{\prime} 30,0^{\prime \prime}$ \\
\hline RE-10 & \begin{tabular}{|l} 
Jaguarari \\
\end{tabular} & QUARTZO & 09으 59' 56,3" & $\mathrm{s}$ & $39055^{\prime} 10,0^{\prime \prime}$ \\
\hline RE-10 & Jaguarari & QUARTZO & $10000^{\prime} 19,0 "$ & $\mathrm{~S}$ & $39055^{\prime} 02,7^{\prime \prime}$ \\
\hline RE-10 & Jaguarari & QUARTZO & 09o $56^{\prime} 56,0^{\prime \prime}$ & $\mathrm{S}$ & $39055^{\prime} 58,6^{\prime \prime}$ \\
\hline RE-10 & Jaguarari & QUARTZO & 09 어 $54^{\prime} 05,6^{\prime \prime}$ & $\mathrm{S}$ & $39 \circ 57^{\prime} 02,2^{\prime \prime}$ \\
\hline RE-10 & Jaguarari & QUARTZO & $09055^{\prime} 03,6^{\prime \prime}$ & $\mathrm{S}$ & $39 \circ 55^{\prime} 05,3^{\prime \prime}$ \\
\hline RE-10 & Jaguarari & QUARTZO & $10005^{\prime} 43,2^{\prime \prime}$ & $\mathrm{S}$ & 40 40 19'38,2" \\
\hline RE-10 & Jaguarari & QUARTZO & $10006^{\prime} 26,0^{\prime \prime}$ & $\mathrm{s}$ & $40017^{\prime} 02,5^{\prime \prime}$ \\
\hline RE-10 & Miguel Calmon & QUARTZO & $11^{\circ} 26^{\prime} 34,7^{\prime \prime}$ & $\mathrm{S}$ & $40031^{\prime} 32,2^{\prime \prime}$ \\
\hline RE-10 & Morro do Chapéu & QUARTZO & $10 \circ 57^{\prime} 10,0^{\prime \prime}$ & $\mathrm{S}$ & $41^{\circ}=15^{\prime} 05,0^{\prime \prime}$ \\
\hline RE-10 & Morro do Chapéu & QUARTZO & $11000^{\prime} 32,0^{\prime \prime}$ & $\mathrm{S}$ & $41^{\circ} 24^{\prime} 39,0^{\prime \prime}$ \\
\hline RE-10 & Ponto Novo & QUARTZO & 10 o $55^{\prime} 16,4^{\prime \prime}$ & $\mathrm{S}$ & 400 11'29,1' \\
\hline RE-10 & Saúde & QUARTZO & 10 - 53' 44,6" & $\mathrm{s}$ & $40022^{\prime} 51,9^{\prime \prime}$ \\
\hline RE-10 & Umburanas & QUARTZO & $10 \circ 43^{\prime} 05,0^{\prime \prime}$ & $\mathrm{S}$ & $41^{\circ}=23^{\prime} 05,0^{\prime \prime}$ \\
\hline RE-10 & Umburanas & QUARTZO & $10034^{\prime} 59,1^{\prime \prime}$ & $\mathrm{S}$ & 41임 $46,7^{\prime \prime}$ \\
\hline RE-10 & Umburanas & QUARTZO & $10043^{\prime} 11,6^{\prime \prime}$ & $\mathrm{S}$ & $41023^{\prime} 02,2^{\prime \prime}$ \\
\hline RE-10 & Várzea Nova & QUARTZO & $11^{\circ} 05^{\prime} 35,0^{\prime \prime}$ & $\mathrm{s}$ & 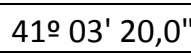 \\
\hline RE-10 & Várzea Nova & QUARTZO & 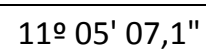 & $\mathrm{s}$ & 41 응 $195^{\prime \prime}$ \\
\hline RE-11 & América Dourada & QUARTZO & 11을 $299,0 "$ & $\mathrm{~S}$ & $41033^{\prime} 23,0^{\prime \prime}$ \\
\hline
\end{tabular}




\begin{tabular}{|c|c|c|c|c|c|}
\hline RE-11 & América Dourada & QUARTZO & $11^{\circ} 31^{\prime} 41,4^{\prime \prime}$ & $\mathrm{s}$ & 41 $42^{\prime} 03,3^{\prime \prime}$ \\
\hline RE-11 & Barra do Mendes & QUARTZO & $12 \div 02^{\prime} 00,0^{\prime \prime}$ & $\mathrm{s}$ & $42^{\circ} 08^{\prime} 30,0^{\prime \prime}$ \\
\hline RE-11 & Barra do Mendes & QUARTZO & $11^{\circ} 44^{\prime} 00,0^{\prime \prime}$ & $\mathrm{s}$ & $42=05^{\prime} 50,0^{\prime \prime}$ \\
\hline RE-11 & Barra do Mendes & QUARTZO & $11^{\circ} 47^{\prime} 50,0^{\prime \prime}$ & $\mathrm{S}$ & $42^{\circ} 02^{\prime} 00,0^{\prime \prime}$ \\
\hline RE-11 & Barra do Mendes & QUARTZO & $11^{\circ}=56^{\prime} 20,0^{\prime \prime}$ & $\mathrm{S}$ & $42^{\circ} 06^{\prime} 12,0^{\prime \prime}$ \\
\hline RE-11 & Barra do Mendes & QUARTZO & 11 은 $23,0^{\prime \prime}$ & $\mathrm{S}$ & $42 \circ 07^{\prime} 35,0^{\prime \prime}$ \\
\hline RE-11 & Barra do Mendes & QUARTZO & $11055^{\prime} 17,4^{\prime \prime}$ & $\mathrm{s}$ & $42 \circ 08^{\prime} 34,9^{\prime \prime}$ \\
\hline RE-11 & Barra do Mendes & QUARTZO & $11056^{\prime} 25,2^{\prime \prime}$ & $\mathrm{s}$ & $42=09^{\prime} 01,5^{\prime \prime}$ \\
\hline RE-11 & Barra do Mendes & QUARTZO & $12 \circ 03^{\prime} 43,6^{\prime \prime}$ & $\mathrm{S}$ & $42^{\circ} 08^{\prime} 22,8^{\prime \prime}$ \\
\hline RE-11 & Barra do Mendes & QUARTZO & $12 \circ 02^{\prime} 29,5^{\prime \prime}$ & $\mathrm{s}$ & $42 \circ 06$ ' $55,7^{\prime \prime}$ \\
\hline RE-11 & Barra do Mendes & QUARTZO & $12^{\circ} 03^{\prime} 24,7^{\prime \prime}$ & $\mathrm{s}$ & $42 \circ 06^{\prime} 24,3^{\prime \prime}$ \\
\hline RE-11 & Barra do Mendes & QUARTZO & $12 \circ 00^{\prime} 37,3^{\prime \prime}$ & $\mathrm{S}$ & $42^{\circ} 04^{\prime} 15,7^{\prime \prime}$ \\
\hline RE-11 & Barra do Mendes & QUARTZO & $12 \div 00^{\prime} 16,0^{\prime \prime}$ & $\mathrm{s}$ & $42 \circ 04^{\prime} 15,5^{\prime \prime}$ \\
\hline RE-11 & Barra do Mendes & QUARTZO & $11^{\circ}=58^{\prime} 10,1^{\prime \prime}$ & $\mathrm{S}$ & 42잉 $57,8^{\prime \prime}$ \\
\hline RE-11 & Barra do Mendes & QUARTZO & $11^{\circ}=59^{\prime} 04,0^{\prime \prime}$ & $\mathrm{s}$ & $42^{\circ} 06^{\prime} 17,0^{\prime \prime}$ \\
\hline RE-11 & Barra do Mendes & QUARTZO & $12^{\circ} 01^{\prime} 04,8^{\prime \prime}$ & $\mathrm{S}$ & $42^{\circ} 08^{\prime} 12,6^{\prime \prime}$ \\
\hline RE-11 & Barra do Mendes & QUARTZO & $12^{\circ} 01^{\prime} 48,1^{\prime \prime}$ & $\mathrm{S}$ & $42^{\circ} 08^{\prime} 20,7^{\prime \prime}$ \\
\hline RE-11 & Barra do Mendes & QUARTZO & $12^{\circ} 01^{\prime} 27,1^{\prime \prime}$ & $\mathrm{s}$ & $42^{\circ} 07^{\prime} 50,7^{\prime \prime}$ \\
\hline RE-11 & Barra do Mendes & QUARTZO & $12^{\circ} 02^{\prime} 51,9^{\prime \prime}$ & $\mathrm{s}$ & $42^{\circ} 08^{\prime} 10,9^{\prime \prime}$ \\
\hline RE-11 & Barra do Mendes & QUARTZO & $11^{\circ} 45^{\prime} 12,6^{\prime \prime}$ & $\mathrm{S}$ & $42^{\circ} 06^{\prime} 32,8^{\prime \prime}$ \\
\hline RE-11 & Barra do Mendes & QUARTZO & $11^{\circ} 46^{\prime} 24,1^{\prime \prime}$ & $\mathrm{s}$ & $42 \circ 02^{\prime} 06,1^{\prime \prime}$ \\
\hline RE-11 & Barra do Mendes & QUARTZO & $12 \circ 04^{\prime} 15,6 "$ & $\mathrm{~s}$ & 42우 $07^{\prime} 40,9^{\prime \prime}$ \\
\hline RE-11 & Barra do Mendes & QUARTZO & $12^{\circ} 05^{\prime} 24,3^{\prime \prime}$ & $\mathrm{s}$ & $42^{\circ} 07^{\prime} 06,7^{\prime \prime}$ \\
\hline RE-11 & Barra do Mendes & QUARTZO & $12^{\circ} 08^{\prime} 34,3^{\prime \prime}$ & $\mathrm{S}$ & $42 \circ 05^{\prime} 55,7^{\prime \prime}$ \\
\hline RE-11 & Barra do Mendes & QUARTZO & $12 \circ 16^{\prime} 21,1^{\prime \prime}$ & $\mathrm{S}$ & $42=05^{\prime} 46,8^{\prime \prime}$ \\
\hline RE-11 & Barra do Mendes & QUARTZO & $12^{\circ} 08^{\prime} 44,5^{\prime \prime}$ & $\mathrm{S}$ & 42응 $03^{\prime} 07,6^{\prime \prime}$ \\
\hline RE-11 & Barra do Mendes & QUARTZO & $11046^{\prime} 33,2^{\prime \prime}$ & $\mathrm{S}$ & $42014^{\prime} 25,3^{\prime \prime}$ \\
\hline RE-11 & Barra do Mendes & QUARTZO & $11^{\circ}=50^{\prime} 05,9^{\prime \prime}$ & $\mathrm{S}$ & $42^{\circ} 08^{\prime} 38,6^{\prime \prime}$ \\
\hline RE-11 & Barra do Mendes & QUARTZO & $11^{\circ}=48^{\prime} 51,1^{\prime \prime}$ & $\mathrm{s}$ & $42^{\circ} 11^{\prime} 23,7^{\prime \prime}$ \\
\hline RE-11 & Barra do Mendes & QUARTZO & $11049^{\prime} 11,7^{\prime \prime}$ & $\mathrm{S}$ & $42=10^{\prime} 28,1^{\prime \prime}$ \\
\hline RE-11 & Barra do Mendes & QUARTZO & $11^{\circ}=40^{\prime} 55,9^{\prime \prime}$ & $\mathrm{s}$ & $42^{\circ} 15^{\prime} 35,1^{\prime \prime}$ \\
\hline RE-11 & Barro Alto & QUARTZO & $11^{\circ}=48^{\prime} 50,0^{\prime \prime}$ & $\mathrm{S}$ & $42^{\circ} 01^{\prime} 15,0^{\prime \prime}$ \\
\hline RE-11 & Barro Alto & QUARTZO & $11^{\circ}=51^{\prime} 08,4^{\prime \prime}$ & $\mathrm{S}$ & 41으 51' 11,0" \\
\hline \begin{tabular}{|l|} 
RE-11 \\
\end{tabular} & Canarana & QUARTZO & $11^{\circ} 38^{\prime} 55,5^{\prime \prime}$ & $\mathrm{s}$ & $41^{\circ} 41^{\prime} 40,1^{\prime \prime}$ \\
\hline RE-11 & Central & QUARTZO & $11^{\circ} 13^{\prime} 00,0^{\prime \prime}$ & $\mathrm{S}$ & $42^{\circ} 13^{\prime} 55,0^{\prime \prime}$ \\
\hline RE-11 & Central & QUARTZO & 11잉 $42,1^{\prime \prime}$ & $\mathrm{S}$ & $42^{\circ} 08^{\prime} 34,8^{\prime \prime}$ \\
\hline RE-11 & Central & QUARTZO & $11^{\circ} 13^{\prime} 01,0^{\prime \prime}$ & $\mathrm{S}$ & 42ㅇ 13' 34,2' \\
\hline RE-11 & Gentio do Ouro & QUARTZO & 11을 $23^{\prime} 42,0^{\prime \prime}$ & $\mathrm{S}$ & $42 \circ 39^{\prime} 42,0^{\prime \prime}$ \\
\hline RE-11 & Gentio do Ouro & QUARTZO & $11^{\circ} 24^{\prime} 06,0^{\prime \prime}$ & $\mathrm{s}$ & $42^{\circ}=39^{\prime} 48,0^{\prime \prime}$ \\
\hline RE-11 & Gentio do Ouro & QUARTZO & $11^{\circ} 30^{\prime} 16,0^{\prime \prime}$ & $\mathrm{s}$ & $42^{\circ} 42^{\prime} 12,0^{\prime \prime}$ \\
\hline RE-11 & Gentio do Ouro & QUARTZO & $1108^{\prime} 00,0^{\prime \prime}$ & $\mathrm{s}$ & 42 $43^{\prime} 06,0^{\prime \prime}$ \\
\hline RE-11 & Gentio do Ouro & QUARTZO & $11^{\circ} 21^{\prime} 20,0^{\prime \prime}$ & $\mathrm{S}$ & $42=37^{\prime} 10,0^{\prime \prime}$ \\
\hline RE-11 & Gentio do Ouro & QUARTZO & $11^{\prime \circ} 28^{\prime} 43,0^{\prime \prime}$ & $\mathrm{s}$ & $42^{\circ} 41^{\prime} 18,0^{\prime \prime}$ \\
\hline RE-11 & Gentio do Ouro & QUARTZO & $11^{\circ}=41^{\prime} 10,0^{\prime \prime}$ & $\mathrm{S}$ & $42^{\circ} 43^{\prime} 05,0^{\prime \prime}$ \\
\hline RE-11 & Gentio do Ouro & QUARTZO & $11034^{\prime} 40,0^{\prime \prime}$ & $\mathrm{S}$ & $42 \circ 43^{\prime} 30,0^{\prime \prime}$ \\
\hline RE-11 & Gentio do Ouro & QUARTZO & $11034^{\prime} 20,0^{\prime \prime}$ & $\mathrm{s}$ & $42 \circ 43^{\prime} 50,0^{\prime \prime}$ \\
\hline \begin{tabular}{|l|} 
RE-11 \\
\end{tabular} & Gentio do Ouro & QUARTZO & $11^{\circ}=31^{\prime} 58,0^{\prime \prime}$ & $\mathrm{s}$ & $42^{\circ} 39^{\prime} 55,0^{\prime \prime}$ \\
\hline RE-11 & Gentio do Ouro & QUARTZO & $11030^{\prime} 40,0^{\prime \prime}$ & $\mathrm{s}$ & $42^{\circ} 39^{\prime} 40,0^{\prime \prime}$ \\
\hline RE-11 & Gentio do Ouro & QUARTZO & $11030^{\prime} 15,0^{\prime \prime}$ & $\mathrm{s}$ & $42 \circ 40^{\prime} 35,0^{\prime \prime}$ \\
\hline RE-11 & Gentio do Ouro & QUARTZO & 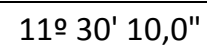 & $\mathrm{s}$ & $42 \circ 41^{\prime} 15,0^{\prime \prime}$ \\
\hline
\end{tabular}




\begin{tabular}{|c|c|c|c|c|c|}
\hline RE-11 & Gentio do Ouro & QUARTZO & 11으이 $15,0 "$ & $\mathrm{~s}$ & $42^{\circ} 42^{\prime} 50,0^{\prime \prime}$ \\
\hline RE-11 & Gentio do Ouro & QUARTZO & 11 ㅇ 30 ' 00,0" & $\mathrm{S}$ & $42^{\circ}=28^{\prime} 00,0^{\prime \prime}$ \\
\hline RE-11 & Gentio do Ouro & QUARTZO & $11026^{\prime} 50,0^{\prime \prime}$ & $\mathrm{S}$ & $42 \circ 29^{\prime} 25,0^{\prime \prime}$ \\
\hline RE-11 & Gentio do Ouro & QUARTZO & $11^{\circ} 25^{\prime} 00,1^{\prime \prime}$ & $\mathrm{S}$ & $42^{\circ}=30^{\prime} 24,9^{\prime \prime}$ \\
\hline RE-11 & Gentio do Ouro & QUARTZO & 11 을 $25^{\prime} 30,0 "$ & $\mathrm{~S}$ & $42^{\circ}=33^{\prime} 31,5^{\prime \prime}$ \\
\hline RE-11 & Gentio do Ouro & QUARTZO & 11 을 $23^{\prime} 50,8 "$ & $\mathrm{~S}$ & $42 \circ 39^{\prime} 52,9^{\prime \prime}$ \\
\hline RE-11 & Gentio do Ouro & QUARTZO & $11^{\circ} 24^{\prime} 26,8^{\prime \prime}$ & $\mathrm{s}$ & 42 o $39^{\prime} 38,3^{\prime \prime}$ \\
\hline RE-11 & Gentio do Ouro & QUARTZO & $11027^{\prime} 32,4^{\prime \prime}$ & $\mathrm{S}$ & $42031^{\prime} 29,9^{\prime \prime}$ \\
\hline RE-11 & Gentio do Ouro & QUARTZO & 11으 41' 34,9" & $\mathrm{S}$ & $42^{\circ} 37^{\prime} 36,8^{\prime \prime}$ \\
\hline RE-11 & Gentio do Ouro & QUARTZO & 11 o $33^{\prime} 06,5^{\prime \prime}$ & $\mathrm{S}$ & $42 \circ 41^{\prime} 54,7^{\prime \prime}$ \\
\hline RE-11 & Gentio do Ouro & QUARTZO & 11 o $33^{\prime} 32,2^{\prime \prime}$ & $\mathrm{S}$ & $42 \circ 41^{\prime} 43,6^{\prime \prime}$ \\
\hline RE-11 & Gentio do Ouro & QUARTZO & $11^{\circ} 32^{\prime} 42,3^{\prime \prime}$ & $\mathrm{S}$ & $42^{\circ}=40^{\prime} 48,2^{\prime \prime}$ \\
\hline RE-11 & Gentio do Ouro & QUARTZO & $11^{\circ} 32^{\prime} 10,7^{\prime \prime}$ & $\mathrm{S}$ & $42 \circ 40^{\prime} 03,1^{\prime \prime}$ \\
\hline RE-11 & Gentio do Ouro & QUARTZO & $11028^{\prime} 34,6 "$ & $\mathrm{~S}$ & $42^{\circ}=41^{\prime} 16,5^{\prime \prime}$ \\
\hline RE-11 & Gentio do Ouro & QUARTZO & $11^{\circ} 27^{\prime} 08,8^{\prime \prime}$ & $\mathrm{S}$ & $42^{\circ}=41^{\prime} 27,6^{\prime \prime}$ \\
\hline RE-11 & Gentio do Ouro & QUARTZO & 11 은 $245,2^{\prime \prime}$ & $\mathrm{S}$ & $42^{\circ}=40^{\prime} 37,8^{\prime \prime}$ \\
\hline RE-11 & Gentio do Ouro & QUARTZO & 11 을 $28,9 "$ & $\mathrm{~S}$ & $42^{\circ} 32^{\prime} 04,3^{\prime \prime}$ \\
\hline RE-11 & Gentio do Ouro & QUARTZO & 11 ㅇ $37^{\prime} 18,8^{\prime \prime}$ & $\mathrm{S}$ & $42 \circ 37^{\prime} 19,0^{\prime \prime}$ \\
\hline RE-11 & Gentio do Ouro & QUARTZO & $11035^{\prime} 35,2 "$ & $\mathrm{~S}$ & $42036^{\prime} 48,9^{\prime \prime}$ \\
\hline RE-11 & Gentio do Ouro & QUARTZO & 11 $30^{\prime} 06,5^{\prime \prime}$ & $\mathrm{S}$ & $42^{\circ}=33^{\prime} 35,1^{\prime \prime}$ \\
\hline RE-11 & Gentio do Ouro & QUARTZO & $11018^{\prime} 28,4^{\prime \prime}$ & $\mathrm{S}$ & $42 \circ 40^{\prime} 11,1^{\prime \prime}$ \\
\hline RE-11 & Gentio do Ouro & QUARTZO & 11ㅇ 19' 45,4" & $\mathrm{S}$ & $42 \circ 40^{\prime} 41,0^{\prime \prime}$ \\
\hline RE-11 & Gentio do Ouro & QUARTZO & 11ㅇ 24' 21,3" & $\mathrm{S}$ & $42^{\circ} 37^{\prime} 34,0^{\prime \prime}$ \\
\hline RE-11 & Gentio do Ouro & QUARTZO & $11^{\circ} 20^{\prime} 34,5^{\prime \prime}$ & $\mathrm{S}$ & $42^{\circ}-37^{\prime} 15,2^{\prime \prime}$ \\
\hline RE-11 & Gentio do Ouro & QUARTZO & $11^{\circ} 33^{\prime} 41,5^{\prime \prime}$ & $\mathrm{S}$ & $42^{\circ}=28^{\prime} 59,2^{\prime \prime}$ \\
\hline RE-11 & Gentio do Ouro & QUARTZO & 11ㅇ $14^{\prime} 45,6^{\prime \prime}$ & $\mathrm{S}$ & $42^{\circ} 46^{\prime} 32,5^{\prime \prime}$ \\
\hline RE-11 & Gentio do Ouro & QUARTZO & 11 o $15^{\prime} 08,4 "$ & $\mathrm{~S}$ & $42 \circ 46^{\prime} 28,9^{\prime \prime}$ \\
\hline RE-11 & Gentio do Ouro & QUARTZO & $11^{\circ} 15^{\prime} 18,0^{\prime \prime}$ & $\mathrm{S}$ & $42^{\circ}=46^{\prime} 16,8^{\prime \prime}$ \\
\hline RE-11 & Gentio do Ouro & QUARTZO & $11^{\circ} 15^{\prime} 30,2^{\prime \prime}$ & $\mathrm{s}$ & $42^{\circ} 46^{\prime} 18,6^{\prime \prime}$ \\
\hline RE-11 & Gentio do Ouro & QUARTZO & $11^{\circ} 15^{\prime} 43,2^{\prime \prime}$ & $\mathrm{S}$ & $42 \circ 46^{\prime} 29,0^{\prime \prime}$ \\
\hline RE-11 & Gentio do Ouro & QUARTZO & 11으 20' 59,8" & $\mathrm{S}$ & $42^{\circ}=28^{\prime} 17,2^{\prime \prime}$ \\
\hline RE-11 & Gentio do Ouro & QUARTZO & 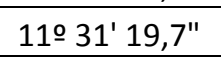 & $\mathrm{s}$ & $42 \circ 44^{\prime} 25,1^{\prime \prime}$ \\
\hline RE-11 & Gentio do Ouro & QUARTZO & 11 o $32^{\prime} 07,1^{\prime \prime}$ & $\mathrm{S}$ & $42^{\circ}=41^{\prime} 08,1^{\prime \prime}$ \\
\hline RE-11 & Gentio do Ouro & QUARTZO & 11 o 29'06,1" & $\mathrm{S}$ & $42036^{\prime} 12,1^{\prime \prime}$ \\
\hline RE-11 & Gentio do Ouro & QUARTZO & $11026^{\prime} 36,4^{\prime \prime}$ & $\mathrm{S}$ & $42 \circ 35^{\prime} 30,1^{\prime \prime}$ \\
\hline RE-11 & Gentio do Ouro & QUARTZO & 11 ㅇ $27^{\prime} 12,8^{\prime \prime}$ & $\mathrm{S}$ & $42^{\circ}=31^{\prime} 11,7^{\prime \prime}$ \\
\hline RE-11 & Gentio do Ouro & QUARTZO & 11 ㅇ $31^{\prime} 03,9 "$ & $\mathrm{~S}$ & $42 \circ 41^{\prime} 07,1^{\prime \prime}$ \\
\hline RE-11 & Gentio do Ouro & QUARTZO & $11031^{\prime} 44,9 "$ & $\mathrm{~S}$ & $42 \circ 41^{\prime} 48,2^{\prime \prime}$ \\
\hline RE-11 & Gentio do Ouro & QUARTZO & 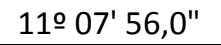 & $\mathrm{s}$ & $42 \circ 43^{\prime} 45,7^{\prime \prime}$ \\
\hline RE-11 & Gentio do Ouro & QUARTZO & 11 의 $26^{\prime} 43,0^{\prime \prime}$ & $\mathrm{S}$ & $42^{\circ}=29^{\prime} 05,0^{\prime \prime}$ \\
\hline RE-11 & Gentio do Ouro & QUARTZO & $11026^{\prime} 38,5^{\prime \prime}$ & $\mathrm{S}$ & $42^{\circ}=28^{\prime} 56,2^{\prime \prime}$ \\
\hline RE-11 & Gentio do Ouro & QUARTZO & $11025^{\prime} 55,2^{\prime \prime}$ & $\mathrm{S}$ & $42 \circ 30^{\prime} 14,9^{\prime \prime}$ \\
\hline RE-11 & Gentio do Ouro & QUARTZO & $11^{\circ} 27^{\prime} 40,2^{\prime \prime}$ & $\mathrm{S}$ & $42^{\circ} 29^{\prime} 46,0^{\prime \prime}$ \\
\hline RE-11 & Ibipeba & QUARTZO & $11^{\circ} 28^{\prime} 04,7^{\prime \prime}$ & $\mathrm{S}$ & $42^{\circ}=15^{\prime} 31,2^{\prime \prime}$ \\
\hline RE-11 & Ibipeba & QUARTZO & 11 o $24^{\prime} 37,2^{\prime \prime}$ & $\mathrm{S}$ & $42^{\circ}=12^{\prime} 51,2^{\prime \prime}$ \\
\hline RE-11 & Ibititá & QUARTZO & 11 $38^{\prime} 05,0^{\prime \prime}$ & $\mathrm{S}$ & $41^{\circ}=52^{\prime} 00,0^{\prime \prime}$ \\
\hline RE-11 & Ibititá & QUARTZO & 11034 ' 11,0" & $\mathrm{s}$ & $41^{\circ}=56^{\prime} 46,0^{\prime \prime}$ \\
\hline RE-11 & Itaguaçu da Bahia & QUARTZO & 11 o $12^{\prime} 36,5^{\prime \prime}$ & $\mathrm{S}$ & $42^{\circ} 22^{\prime} 18,9^{\prime \prime}$ \\
\hline RE-11 & Itaguaçu da Bahia & QUARTZO & 11 o 06 ' $24,4^{\prime \prime}$ & $\mathrm{S}$ & $42 \div 25^{\prime} 06,2^{\prime \prime}$ \\
\hline RE-11 & Itaguaçu da Bahia & QUARTZO & 110 05' 46,4" & $\mathrm{s}$ & $42011^{\prime} 29,9^{\prime \prime}$ \\
\hline
\end{tabular}




\begin{tabular}{|c|c|c|c|c|c|}
\hline RE-11 & João Dourado & QUARTZO & $11^{\circ} 12^{\prime} 16,0^{\prime \prime}$ & $\mathrm{s}$ & 41을 $29^{\prime} 34,0^{\prime \prime}$ \\
\hline RE-11 & Lapão & QUARTZO & $11^{\circ} 27^{\prime} 50,0 "$ & $S$ & $41^{\circ}=52^{\prime} 45,0^{\prime \prime}$ \\
\hline RE-11 & Lapão & QUARTZO & $11^{\circ} 27^{\prime} 56,0^{\prime \prime}$ & $S$ & $41049^{\prime} 38,0^{\prime \prime}$ \\
\hline RE-11 & Lapão & QUARTZO & $11^{\circ} 27^{\prime} 57,1^{\prime \prime}$ & $S$ & $41048^{\prime} 04,0^{\prime \prime}$ \\
\hline RE-11 & Lapão & QUARTZO & $11^{\circ} 27^{\prime} 54,4^{\prime \prime}$ & $S$ & $41^{\circ} 53^{\prime} 52,2^{\prime \prime}$ \\
\hline RE-11 & Presidente Dutra & QUARTZO & $11^{\circ} 11^{\prime}$ 50,0" & $S$ & $41058^{\prime} 35,0^{\prime \prime}$ \\
\hline RE-11 & Uibaí & QUARTZO & 11을 $23^{\prime} 40,0^{\prime \prime}$ & $S$ & $42 \circ 07$ ' $15,0^{\prime \prime}$ \\
\hline RE-11 & Uibaí & QUARTZO & $11^{\circ} 23^{\prime} 02,0^{\prime \prime}$ & $S$ & $42 \circ 06$ '52,0" \\
\hline RE-11 & Xique-Xique & QUARTZO & $11^{\circ} 42^{\prime} 06,0^{\prime \prime}$ & $S$ & $42 \circ 46^{\prime} 12,0^{\prime \prime}$ \\
\hline RE-11 & Xique-Xique & QUARTZO & $10045^{\prime} 58,0^{\prime \prime}$ & $S$ & $42^{\circ}=35^{\prime} 00,0^{\prime \prime}$ \\
\hline RE-11 & Xique-Xique & QUARTZO & $10020^{\prime} 35,0^{\prime \prime}$ & $\mathrm{S}$ & $42 \circ 26^{\prime} 23,0^{\prime \prime}$ \\
\hline RE-11 & Xique-Xique & QUARTZO & $10036^{\prime} 53,0^{\prime \prime}$ & $S$ & $42^{\circ} 33^{\prime} 19,0^{\prime \prime}$ \\
\hline RE-11 & Xique-Xique & QUARTZO & $10 \circ 57^{\prime} 31,0 "$ & $S$ & $42^{\circ}=41^{\prime} 06,0^{\prime \prime}$ \\
\hline RE-11 & Xique-Xique & QUARTZO & $10048^{\prime} 10,0^{\prime \prime}$ & $S$ & $42^{\circ}=36^{\prime} 11,0^{\prime \prime}$ \\
\hline RE-11 & Xique-Xique & QUARTZO & $10=46^{\prime} 59,0^{\prime \prime}$ & $S$ & $42-38^{\prime} 54,0^{\prime \prime}$ \\
\hline RE-11 & Xique-Xique & QUARTZO & $10045^{\prime} 46,0^{\prime \prime}$ & $S$ & $42^{\circ} 38^{\prime} 46,0^{\prime \prime}$ \\
\hline RE-11 & Xique-Xique & QUARTZO & $10047^{\prime} 32,0^{\prime \prime}$ & $S$ & $42^{\circ}=38^{\prime} 12,0^{\prime \prime}$ \\
\hline RE-11 & Xique-Xique & QUARTZO & $10046^{\prime} 59,0^{\prime \prime}$ & $S$ & $42^{2} \circ 36^{\prime} 48,0^{\prime \prime}$ \\
\hline RE-11 & Xique-Xique & QUARTZO & $10=47^{\prime} 16,0^{\prime \prime}$ & $\mathrm{S}$ & $42^{\circ}=41^{\prime} 24,0^{\prime \prime}$ \\
\hline RE-11 & Xique-Xique & QUARTZO & $10 \circ 50^{\prime} 15,0^{\prime \prime}$ & $S$ & $42 \circ 35^{\prime} 32,0^{\prime \prime}$ \\
\hline RE-11 & Xique-Xique & QUARTZO & $11^{\circ} 33^{\prime} 19,5^{\prime \prime}$ & $S$ & $42^{\circ} 50^{\prime} 41,3 "$ \\
\hline RE-11 & Xique-Xique & QUARTZO & $10024^{\prime} 41,1^{\prime \prime}$ & $\mathrm{S}$ & $42 \circ 29^{\prime} 01,2^{\prime \prime}$ \\
\hline RE-11 & Xique-Xique & QUARTZO & 11으 35' 24,4" & $\mathrm{S}$ & $42^{\prime 2} 58^{\prime} 07,2^{\prime \prime}$ \\
\hline RE-11 & Xique-Xique & QUARTZO & $10046^{\prime} 31,5^{\prime \prime}$ & $S$ & $42^{\circ}-37^{\prime} 54,6^{\prime \prime}$ \\
\hline RE-11 & Xique-Xique & QUARTZO & $10048^{\prime} 29,3^{\prime \prime}$ & $S$ & $42^{\circ}=37^{\prime} 58,6^{\prime \prime}$ \\
\hline RE-11 & Xique-Xique & QUARTZO & $10046^{\prime} 25,3^{\prime \prime}$ & $\mathrm{s}$ & $42 \circ 40^{\prime} 49,3 "$ \\
\hline RE-11 & Xique-Xique & \begin{tabular}{|l|} 
QUARTZO \\
\end{tabular} & $10049^{\prime} 37,0^{\prime \prime}$ & $S$ & $42 \circ 35^{\prime} 24,9^{\prime \prime}$ \\
\hline RE-11 & Xique-Xique & QUARTZO & $10046^{\prime} 52,8^{\prime \prime}$ & $S$ & $42^{\circ}{ }^{\prime} 41^{\prime} 05,2^{\prime \prime}$ \\
\hline RE-11 & Xique-Xique & QUARTZO & $10045^{\prime} 05,5^{\prime \prime}$ & $\mathrm{s}$ & $42 \div 39^{\prime} 10,6^{\prime \prime}$ \\
\hline RE-11 & Xique-Xique & QUARTZO & 10ㅇ 44' 37,9" & $S$ & $42 \circ 40^{\prime} 07,7^{\prime \prime}$ \\
\hline RE-11 & Xique-Xique & QUARTZO & $10044^{\prime} 04,2^{\prime \prime}$ & $S$ & $42 \div 39^{\prime} 32,0^{\prime \prime}$ \\
\hline RE-11 & Xique-Xique & \begin{tabular}{|l|} 
QUARTZO \\
\end{tabular} & $10043^{\prime} 25,0^{\prime \prime}$ & $S$ & $42^{\circ} 38^{\prime} 46,1^{\prime \prime}$ \\
\hline RE-11 & Xique-Xique & QUARTZO & 10영 $49^{\prime} 31,9^{\prime \prime}$ & $S$ & $42^{\circ} \circ 35^{\prime} 06,4^{\prime \prime}$ \\
\hline RE-11 & Xique-Xique & QUARTZO & $10=50^{\prime} 50,3^{\prime \prime}$ & $S$ & 42 ㄴ 39' $27,6^{\prime \prime}$ \\
\hline RE-11 & Xique-Xique & QUARTZO & $11^{\circ}=42^{\prime} 25,3^{\prime \prime}$ & $S$ & $42=45^{\prime} 24,5^{\prime \prime}$ \\
\hline RE-12 & Abaíra & QUARTZO & 13임 17' 11,0" & $S$ & $41^{\circ}$ 49'03,0" \\
\hline RE-12 & Abaíra & QUARTZO & 13우 17' 41,0" & $S$ & $4149^{\prime} 46,0^{\prime \prime}$ \\
\hline RE-12 & Barra da Estiva & QUARTZO & 13으 34' 24,0" & $S$ & $41025^{\prime} 18,0^{\prime \prime}$ \\
\hline RE-12 & Boninal & QUARTZO & $12^{\circ} 47^{\prime} 50,0^{\prime \prime}$ & $\mathrm{s}$ & $41^{\circ} 37^{\prime} 30,0^{\prime \prime}$ \\
\hline $\mathrm{RE}-12$ & Boninal & QUARTZO & $12 \circ 44^{\prime} 45,0^{\prime \prime}$ & $S$ & $41056^{\prime} 45,0^{\prime \prime}$ \\
\hline $\mathrm{RE}-12$ & Boninal & QUARTZO & $12^{\circ} 4^{\prime} 6^{\prime} 40,0^{\prime \prime}$ & $S$ & 410 55' 55,0" \\
\hline RE-12 & Boninal & \begin{tabular}{|l|} 
QUARTZO \\
\end{tabular} & $12^{\circ}=45^{\prime} 45,0^{\prime \prime}$ & $S$ & 41으 57'00,0" \\
\hline RE-12 & Boninal & QUARTZO & $12^{\circ} 44^{\prime} 05,0^{\prime \prime}$ & $S$ & 41ㅇ 57'05,0" \\
\hline RE-12 & Boninal & QUARTZO & $12^{\circ} 45^{\prime} 10,0^{\prime \prime}$ & $S$ & $41^{\circ} 55^{\prime} 40,0^{\prime \prime}$ \\
\hline RE-12 & Boninal & \begin{tabular}{|l|} 
QUARTZO \\
\end{tabular} & $12^{\circ}{ }^{\circ} 46^{\prime} 40,0^{\prime \prime}$ & $S$ & $41^{\circ}$ 57' 30,0" \\
\hline RE-12 & Boninal & QUARTZO & 12ㅇ 48 $00,0^{\prime \prime}$ & $S$ & $41^{\circ}$ 56' 30,0" \\
\hline RE-12 & Boninal & QUARTZO & $12^{\circ}{ }^{\circ} 46^{\prime} 00,0^{\prime \prime}$ & $S$ & $41^{\circ} 56^{\prime} 00,0^{\prime \prime}$ \\
\hline RE-12 & Boninal & QUARTZO & $12^{\circ}{ }^{\prime} 44^{\prime} 30,0^{\prime \prime}$ & $S$ & $41055^{\prime} 15,0^{\prime \prime}$ \\
\hline RE-12 & Boninal & QUARTZO & $12^{\circ}$ 47' 05,0" & $S$ & $41^{\prime}$ 56' 15,0" \\
\hline RE-12 & Boninal & QUARTZO & $12 \circ 47^{\prime} 20,0^{\prime \prime}$ & $S$ & $41^{\circ}$ 58' 15,0" \\
\hline
\end{tabular}




\begin{tabular}{|c|c|c|c|c|c|}
\hline RE-12 & Botuporã & QUARTZO & 13ㅇ 18' 05,0" & $\mathrm{s}$ & $42 \circ 37^{\prime} 30,0^{\prime \prime}$ \\
\hline RE-12 & Botuporã & QUARTZO & 13 $17^{\prime} 55,0^{\prime \prime}$ & $\mathrm{s}$ & $42 \circ 34^{\prime} 35,0^{\prime \prime}$ \\
\hline RE-12 & Brotas de Macaúbas & QUARTZO & $12 \circ 04^{\prime} 45,0^{\prime \prime}$ & $\mathrm{S}$ & $42 \circ 21^{\prime} 15,0^{\prime \prime}$ \\
\hline RE-12 & Brotas de Macaúbas & QUARTZO & 12 ㅇ $01^{\prime} 05,0^{\prime \prime}$ & $\mathrm{S}$ & $42 \circ 36^{\prime} 32,0^{\prime \prime}$ \\
\hline $\mathrm{RE}-12$ & Brotas de Macaúbas & QUARTZO & 11 o 52' 28,0" & $\mathrm{s}$ & $42 \circ 44^{\prime} 18,0^{\prime \prime}$ \\
\hline RE-12 & Brotas de Macaúbas & QUARTZO & 12ㅇ $15^{\prime} 11,0^{\prime \prime}$ & $\mathrm{S}$ & $42^{\circ}=15^{\prime} 11,0^{\prime \prime}$ \\
\hline RE-12 & Brotas de Macaúbas & QUARTZO & 12 ㅇ $11^{\prime} 43,0^{\prime \prime}$ & $\mathrm{S}$ & $42 \circ 12^{\prime} 20,0^{\prime \prime}$ \\
\hline RE-12 & Brotas de Macaúbas & QUARTZO & 12 o 06 ' 00,0" & $\mathrm{S}$ & $42 \circ 33^{\prime} 18,0^{\prime \prime}$ \\
\hline RE-12 & Brotas de Macaúbas & QUARTZO & 11 o 52' $36,0^{\prime \prime}$ & $\mathrm{S}$ & $42^{\circ}=42^{\prime} 30,0^{\prime \prime}$ \\
\hline RE-12 & Brotas de Macaúbas & QUARTZO & 11은 59' 50,0" & $\mathrm{S}$ & $42^{\circ} 35^{\prime} 31,0^{\prime \prime}$ \\
\hline RE-12 & Brotas de Macaúbas & QUARTZO & 12 o 04 ' $18,0^{\prime \prime}$ & $\mathrm{S}$ & $42 \circ 28^{\prime} 14,0^{\prime \prime}$ \\
\hline RE-12 & Brotas de Macaúbas & QUARTZO & 12 ㅇ $00^{\prime} 16,0^{\prime \prime}$ & $\mathrm{S}$ & $42^{\circ} 29^{\prime} 00,0^{\prime \prime}$ \\
\hline RE-12 & Brotas de Macaúbas & QUARTZO & 11 인 $5422,0^{\prime \prime}$ & $\mathrm{S}$ & $42^{\circ}=38^{\prime} 23,0^{\prime \prime}$ \\
\hline RE-12 & Brotas de Macaúbas & QUARTZO & 12 o $05^{\prime} 14,0 "$ & $\mathrm{~s}$ & $42 \div 25^{\prime} 00,0^{\prime \prime}$ \\
\hline RE-12 & Brotas de Macaúbas & QUARTZO & 11 o 54' 29,0" & $\mathrm{S}$ & $42 \circ 38^{\prime} 55,0^{\prime \prime}$ \\
\hline RE-12 & Brotas de Macaúbas & QUARTZO & $12 \circ 02^{\prime} 46,0^{\prime \prime}$ & $\mathrm{S}$ & $42^{\circ}=33^{\prime} 42,0^{\prime \prime}$ \\
\hline RE-12 & Brotas de Macaúbas & QUARTZO & 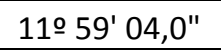 & $\mathrm{S}$ & $42^{\circ}=42^{\prime} 03,0^{\prime \prime}$ \\
\hline RE-12 & Brotas de Macaúbas & QUARTZO & 11 o $53^{\prime} 58,0^{\prime \prime}$ & $\mathrm{S}$ & $42^{\circ}=38^{\prime} 58,0^{\prime \prime}$ \\
\hline RE-12 & Brotas de Macaúbas & QUARTZO & $11^{\circ}=52^{\prime} 25,0^{\prime \prime}$ & $\mathrm{S}$ & $42 \circ 44^{\prime} 50,0^{\prime \prime}$ \\
\hline RE-12 & Brotas de Macaúbas & QUARTZO & $11^{\circ}=51^{\prime} 40,0^{\prime \prime}$ & $\mathrm{S}$ & $42^{\circ}-44^{\prime} 02,0^{\prime \prime}$ \\
\hline RE-12 & Brotas de Macaúbas & QUARTZO & $11^{\circ} 49^{\prime} 40,0^{\prime \prime}$ & $\mathrm{s}$ & $42^{\circ} 46^{\prime} 00,0^{\prime \prime}$ \\
\hline RE-12 & Brotas de Macaúbas & QUARTZO & 12 o $08^{\prime} 26,6^{\prime \prime}$ & $\mathrm{S}$ & 42 잉 $17,7^{\prime \prime}$ \\
\hline RE-12 & Brotas de Macaúbas & QUARTZO & $12 \circ 08^{\prime} 19,5^{\prime \prime}$ & $\mathrm{S}$ & $42^{\circ} 09^{\prime} 42,8^{\prime \prime}$ \\
\hline RE-12 & Brotas de Macaúbas & QUARTZO & $12 \circ 07^{\prime} 12,3^{\prime \prime}$ & $\mathrm{S}$ & $42^{\circ} 10^{\prime} 16,6^{\prime \prime}$ \\
\hline RE-12 & Brotas de Macaúbas & QUARTZO & 12 o $06^{\prime} 51,0 "$ & $\mathrm{~s}$ & $42 \circ 08^{\prime} 54,5^{\prime \prime}$ \\
\hline RE-12 & Brotas de Macaúbas & QUARTZO & 12 o 06 ' 38,6" & $\mathrm{s}$ & $42^{\circ} 08^{\prime} 33,1^{\prime \prime}$ \\
\hline RE-12 & Caturama & QUARTZO & 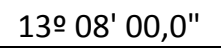 & $\mathrm{S}$ & $42^{\circ}=12^{\prime} 48,0^{\prime \prime}$ \\
\hline RE-12 & Érico Cardoso & QUARTZO & 13 23' 54,0" & $\mathrm{s}$ & $42 \circ 11^{\prime} 02,0^{\prime \prime}$ \\
\hline RE-12 & Érico Cardoso & QUARTZO & 13으 28 ' 55,0" & $\mathrm{S}$ & $42^{\circ} 06^{\prime} 16,0^{\prime \prime}$ \\
\hline RE-12 & Ibicoara & QUARTZO & 13 o 26' 20,0" & $\mathrm{S}$ & $41^{\circ} 21^{\prime} 40,0^{\prime \prime}$ \\
\hline RE-12 & Ibicoara & QUARTZO & $13 \circ 28^{\prime} 40,0^{\prime \prime}$ & $\mathrm{S}$ & $41^{\circ} 26^{\prime} 40,0^{\prime \prime}$ \\
\hline RE-12 & Ibipitanga & QUARTZO & $12 \circ 45^{\prime} 15,0 "$ & $\mathrm{~S}$ & $42^{\circ} 19^{\prime} 13,0^{\prime \prime}$ \\
\hline RE-12 & Ibipitanga & QUARTZO & 12 - 49' 30,0" & $\mathrm{S}$ & $42^{\circ} 16^{\prime} 30,0^{\prime \prime}$ \\
\hline RE-12 & Ibipitanga & QUARTZO & 12 - 49' 45,0" & $\mathrm{S}$ & $42^{\circ} 17^{\prime} 00,0^{\prime \prime}$ \\
\hline RE-12 & Ibipitanga & QUARTZO & $12 \circ 48^{\prime} 30,0 "$ & $\mathrm{~S}$ & $42^{\circ} 17^{\prime} 00,0^{\prime \prime}$ \\
\hline RE-12 & Ibipitanga & QUARTZO & 12 o 49' 00,0" & $\mathrm{s}$ & $42^{\circ} 15^{\prime} 50,0^{\prime \prime}$ \\
\hline RE-12 & Ibipitanga & QUARTZO & $12 \circ 47^{\prime} 45,0^{\prime \prime}$ & $\mathrm{s}$ & $42 \circ 21^{\prime} 15,0^{\prime \prime}$ \\
\hline RE-12 & Ibipitanga & QUARTZO & 12 o 56' 15,0" & $\mathrm{S}$ & $42 \circ 17^{\prime} 30,0^{\prime \prime}$ \\
\hline RE-12 & Ibipitanga & QUARTZO & 12 ㅇ' $30,0 "$ & $\mathrm{~S}$ & $42^{\circ} 19^{\prime} 15,0^{\prime \prime}$ \\
\hline RE-12 & Ibitiara & QUARTZO & $12 \circ 43^{\prime} 30,0^{\prime \prime}$ & $\mathrm{s}$ & $42^{\circ} 15^{\prime} 15,0^{\prime \prime}$ \\
\hline RE-12 & Ibitiara & QUARTZO & 12ㅇ 43' 15,0" & $\mathrm{s}$ & $42 \circ 09^{\prime} 15,0^{\prime \prime}$ \\
\hline RE-12 & Ibitiara & QUARTZO & 12 o 43' 10,0" & $\mathrm{S}$ & $42 \circ 05^{\prime} 30,0^{\prime \prime}$ \\
\hline RE-12 & Ibitiara & QUARTZO & $12 \circ 41^{\prime} 15,0^{\prime \prime}$ & $\mathrm{S}$ & $42^{\circ} 12^{\prime} 45,0^{\prime \prime}$ \\
\hline RE-12 & Ibitiara & QUARTZO & $12 \circ 36^{\prime} 15,0^{\prime \prime}$ & $\mathrm{S}$ & $42^{\circ} 08^{\prime} 45,0^{\prime \prime}$ \\
\hline RE-12 & Ibitiara & QUARTZO & 12 o $36^{\prime} 30,0^{\prime \prime}$ & $\mathrm{S}$ & $42^{\circ} 17^{\prime} 45,0^{\prime \prime}$ \\
\hline RE-12 & Ibitiara & QUARTZO & $12 \div 29$ ' 30,0" & $\mathrm{s}$ & $42^{\circ} 08^{\prime} 00,0^{\prime \prime}$ \\
\hline RE-12 & Ibitiara & QUARTZO & $12 \circ 36^{\prime} 45,0^{\prime \prime}$ & $\mathrm{S}$ & $42^{\circ} 23^{\prime} 15,0^{\prime \prime}$ \\
\hline RE-12 & Ibitiara & QUARTZO & $12 \div 30$ ' $00,0^{\prime \prime}$ & $\mathrm{s}$ & $42^{\circ} 16^{\prime} 00,0^{\prime \prime}$ \\
\hline RE-12 & Ibitiara & QUARTZO & $12 \circ 24^{\prime} 15,0^{\prime \prime}$ & $\mathrm{S}$ & $42^{\circ}=11^{\prime} 30,0^{\prime \prime}$ \\
\hline RE-12 & Ibitiara & QUARTZO & 12 o $37^{\prime} 30,0^{\prime \prime}$ & $\mathrm{s}$ & $42 \circ 09^{\prime} 15,0^{\prime \prime}$ \\
\hline
\end{tabular}




\begin{tabular}{|c|c|c|c|c|c|}
\hline RE-12 & Ibitiara & QUARTZO & $12 \circ 30^{\prime} 45,0^{\prime \prime}$ & $\mathrm{s}$ & $42 \circ 08^{\prime} 45,0^{\prime \prime}$ \\
\hline RE-12 & Ibitiara & QUARTZO & $12^{\circ} 35^{\prime} 30,0^{\prime \prime}$ & $\mathrm{s}$ & $42 \circ 07^{\prime} 30,0^{\prime \prime}$ \\
\hline RE-12 & Ibitiara & QUARTZO & $12029^{\prime} 15,0^{\prime \prime}$ & $\mathrm{S}$ & $42 \circ 06^{\prime} 15,0^{\prime \prime}$ \\
\hline RE-12 & Ibitiara & QUARTZO & 12 - $27^{\prime} 30,0^{\prime \prime}$ & $\mathrm{S}$ & $42 \circ 17^{\prime} 00,0^{\prime \prime}$ \\
\hline RE-12 & Ibitiara & QUARTZO & 12 o 39 ' 42,0" & $\mathrm{S}$ & $42 \circ 12^{\prime} 12,0^{\prime \prime}$ \\
\hline RE-12 & Ibitiara & QUARTZO & 12 o 39' 19,0" & $\mathrm{S}$ & $42^{\circ}=13^{\prime} 24,0^{\prime \prime}$ \\
\hline RE-12 & Ibitiara & QUARTZO & 12 o 39' 46,0" & $\mathrm{S}$ & $42 \circ 13^{\prime} 52,0^{\prime \prime}$ \\
\hline RE-12 & Ibitiara & QUARTZO & 12 o $38^{\prime} 27,0^{\prime \prime}$ & $\mathrm{S}$ & $42 \circ 13^{\prime} 48,0^{\prime \prime}$ \\
\hline RE-12 & Ibitiara & QUARTZO & $12 \div 36^{\prime} 00,0^{\prime \prime}$ & $\mathrm{S}$ & $42^{\circ}=15^{\prime} 15,0^{\prime \prime}$ \\
\hline RE-12 & Ibitiara & QUARTZO & 12 ㅇ 37' 15,0" & $\mathrm{S}$ & $42 \circ 10^{\prime} 45,0^{\prime \prime}$ \\
\hline RE-12 & Ibitiara & QUARTZO & 12 - 33' 00,0" & $\mathrm{S}$ & $42 \circ 11^{\prime} 00,0^{\prime \prime}$ \\
\hline RE-12 & Ibitiara & QUARTZO & $12 \circ 40^{\prime} 15,0^{\prime \prime}$ & $\mathrm{S}$ & $42^{\circ} 16^{\prime} 15,0^{\prime \prime}$ \\
\hline RE-12 & Ibitiara & QUARTZO & $12 \circ 38^{\prime} 00,0^{\prime \prime}$ & $\mathrm{S}$ & $42^{\circ}=18^{\prime} 30,0^{\prime \prime}$ \\
\hline RE-12 & Ibitiara & QUARTZO & 12 잉 $30,0^{\prime \prime}$ & $\mathrm{S}$ & $42^{\circ}=19^{\prime} 00,0^{\prime \prime}$ \\
\hline RE-12 & Ibitiara & QUARTZO & 12 o $38^{\prime} 15,0^{\prime \prime}$ & $\mathrm{S}$ & $42 \circ 13^{\prime} 30,0^{\prime \prime}$ \\
\hline RE-12 & Ibitiara & QUARTZO & $12 \div 35^{\prime} 00,0^{\prime \prime}$ & $\mathrm{S}$ & $42^{\circ}=14^{\prime} 30,0^{\prime \prime}$ \\
\hline RE-12 & Ibitiara & QUARTZO & $12 \circ 32^{\prime} 40,0^{\prime \prime}$ & $\mathrm{S}$ & $42^{\circ}=17^{\prime} 00,0^{\prime \prime}$ \\
\hline RE-12 & Ibitiara & QUARTZO & 12 ㅇ $42^{\prime} 15,0^{\prime \prime}$ & $\mathrm{S}$ & $42^{\circ}=18^{\prime} 15,0^{\prime \prime}$ \\
\hline RE-12 & Ibitiara & QUARTZO & $12 \circ 36$ '00,0" & $\mathrm{s}$ & $42^{\circ}=17^{\prime} 00,0^{\prime \prime}$ \\
\hline RE-12 & Ibitiara & QUARTZO & $12 \circ 35^{\prime} 00,0^{\prime \prime}$ & $\mathrm{s}$ & $42 \circ 15^{\prime} 30,0^{\prime \prime}$ \\
\hline RE-12 & Ibitiara & QUARTZO & $12 \circ 33^{\prime} 45,0 "$ & $\mathrm{~S}$ & $42^{\circ}=26^{\prime} 45,0^{\prime \prime}$ \\
\hline RE-12 & Ibitiara & QUARTZO & 12 o $39^{\prime} 45,0 "$ & $\mathrm{~S}$ & $42^{\circ}=17^{\prime} 00,0^{\prime \prime}$ \\
\hline RE-12 & Ibitiara & QUARTZO & 12 o 39' $15,0^{\prime \prime}$ & $\mathrm{S}$ & $42 \circ 21^{\prime} 15,0^{\prime \prime}$ \\
\hline RE-12 & Ibitiara & QUARTZO & $12 \circ 41^{\prime} 50,0 "$ & $\mathrm{~S}$ & $42 \circ 09^{\prime} 50,0^{\prime \prime}$ \\
\hline RE-12 & Ibitiara & QUARTZO & 12 은 $40,0 "$ & $\mathrm{~S}$ & $42 \circ 10^{\prime} 10,0^{\prime \prime}$ \\
\hline RE-12 & Ibitiara & QUARTZO & $12 \circ 41^{\prime} 00,0^{\prime \prime}$ & $\mathrm{S}$ & $42 \circ 14^{\prime} 10,0^{\prime \prime}$ \\
\hline RE-12 & Ibitiara & QUARTZO & $12 \circ 40^{\prime} 00,0^{\prime \prime}$ & $\mathrm{s}$ & 42 ㅇ $14^{\prime} 10,0^{\prime \prime}$ \\
\hline RE-12 & Ibitiara & QUARTZO & 12 - $35^{\prime} 50,0^{\prime \prime}$ & $\mathrm{S}$ & $42^{\circ}=15^{\prime} 50,0^{\prime \prime}$ \\
\hline RE-12 & Ibitiara & QUARTZO & $12 \circ 35^{\prime} 50,0 "$ & $\mathrm{~S}$ & $42^{\circ}=15^{\prime} 50,0^{\prime \prime}$ \\
\hline RE-12 & Ibitiara & QUARTZO & $12 \circ 34^{\prime} 20,0^{\prime \prime}$ & $\mathrm{S}$ & $42 \circ 15^{\prime} 50,0^{\prime \prime}$ \\
\hline RE-12 & Ibitiara & QUARTZO & $12 \circ 42^{\prime} 20,0^{\prime \prime}$ & $\mathrm{S}$ & $42 \circ 09^{\prime} 20,0^{\prime \prime}$ \\
\hline RE-12 & Ibitiara & QUARTZO & $12 \circ 41^{\prime} 30,0^{\prime \prime}$ & $\mathrm{s}$ & $42^{\circ}=12^{\prime} 30,0^{\prime \prime}$ \\
\hline RE-12 & Ibitiara & QUARTZO & $12 \circ 38^{\prime} 50,0^{\prime \prime}$ & $\mathrm{S}$ & $42 \circ 10^{\prime} 40,0^{\prime \prime}$ \\
\hline RE-12 & Ibitiara & QUARTZO & 12 o $38^{\prime} 30,0^{\prime \prime}$ & $\mathrm{S}$ & $42 \circ 10^{\prime} 40,0^{\prime \prime}$ \\
\hline RE-12 & Ibitiara & QUARTZO & 12 o $35^{\prime} 40,0^{\prime \prime}$ & $\mathrm{S}$ & $42 \circ 15^{\prime} 20,0^{\prime \prime}$ \\
\hline RE-12 & Ibitiara & QUARTZO & $12 \circ 28^{\prime} 33,0^{\prime \prime}$ & $\mathrm{S}$ & $42 \circ 11^{\prime} 04,4^{\prime \prime}$ \\
\hline RE-12 & Ipupiara & QUARTZO & 11 연 $40,0 "$ & $\mathrm{~S}$ & $42^{\circ}=26^{\prime} 55,0^{\prime \prime}$ \\
\hline RE-12 & Ipupiara & QUARTZO & 11 ㅇ 56' 50,0" & $\mathrm{S}$ & $42 \circ 29^{\prime} 26,0^{\prime \prime}$ \\
\hline RE-12 & Ipupiara & QUARTZO & 11 o 56' 20,0" & $\mathrm{s}$ & $42 \circ 22^{\prime} 50,0^{\prime \prime}$ \\
\hline $\mathrm{RE}-12$ & Ipupiara & QUARTZO & 11 o 50' $35,0^{\prime \prime}$ & $\mathrm{S}$ & $42 \circ 35^{\prime} 10,0^{\prime \prime}$ \\
\hline RE-12 & Ipupiara & QUARTZO & 11은 $52^{\prime} 00,0 "$ & $\mathrm{~S}$ & $42^{\circ}=38^{\prime} 43,0^{\prime \prime}$ \\
\hline $\mathrm{RE}-12$ & Ipupiara & QUARTZO & 11ㅇ 51' 58,0" & $\mathrm{S}$ & $42^{\circ}=39^{\prime} 40,0^{\prime \prime}$ \\
\hline RE-12 & Ipupiara & QUARTZO & $11^{\circ} 48^{\prime} 03,5^{\prime \prime}$ & $\mathrm{s}$ & 42 잉 $13,8^{\prime \prime}$ \\
\hline RE-12 & Ipupiara & QUARTZO & $11047^{\prime} 46,1^{\prime \prime}$ & $\mathrm{s}$ & $42 \circ 15^{\prime} 38,0^{\prime \prime}$ \\
\hline RE-12 & Ipupiara & QUARTZO & $11^{\circ} 47^{\prime} 43,6^{\prime \prime}$ & $\mathrm{S}$ & $42^{\circ}=15^{\prime} 11,6^{\prime \prime}$ \\
\hline RE-12 & Ipupiara & QUARTZO & $11047^{\prime} 42,1^{\prime \prime}$ & $\mathrm{S}$ & $42 \circ 14^{\prime} 35,0^{\prime \prime}$ \\
\hline RE-12 & Macaúbas & QUARTZO & 13ㅇ $12^{\prime} 00,0^{\prime \prime}$ & $\mathrm{S}$ & $42 \circ 34$ ' $36,0^{\prime \prime}$ \\
\hline RE-12 & Macaúbas & QUARTZO & $12056^{\prime} 11,0^{\prime \prime}$ & $\mathrm{s}$ & $42 \circ 46^{\prime} 23,0^{\prime \prime}$ \\
\hline RE-12 & Macaúbas & QUARTZO & 13으 02' 30,0" & $\mathrm{S}$ & $42^{\circ}=46^{\prime} 00,0^{\prime \prime}$ \\
\hline RE-12 & Macaúbas & QUARTZO & 13ㅇ 07' 10,0" & $\mathrm{s}$ & $42 \circ 36^{\prime} 35,0^{\prime \prime}$ \\
\hline
\end{tabular}




\begin{tabular}{|c|c|c|c|c|c|}
\hline RE-12 & Mucugê & QUARTZO & $12 \circ 49^{\prime} 50,0^{\prime \prime}$ & $\mathrm{s}$ & $41^{\circ} 37^{\prime} 00,0^{\prime \prime}$ \\
\hline RE-12 & Mucugê & QUARTZO & $12^{\circ} 52^{\prime} 15,0^{\prime \prime}$ & $\mathrm{s}$ & $41^{\circ}=38^{\prime} 00,0^{\prime \prime}$ \\
\hline RE-12 & Mucugê & QUARTZO & 12 o 52' $30,0^{\prime \prime}$ & $\mathrm{S}$ & $41035^{\prime} 15,0^{\prime \prime}$ \\
\hline RE-12 & Mucugê & QUARTZO & $12 \circ 42^{\prime} 30,0^{\prime \prime}$ & $\mathrm{S}$ & $41036^{\prime} 00,0^{\prime \prime}$ \\
\hline RE-12 & Mucugê & QUARTZO & 13을 12' 15,0" & $\mathrm{s}$ & $41^{\circ} 30^{\prime} 45,0^{\prime \prime}$ \\
\hline RE-12 & Mucugê & QUARTZO & 13으 04' 30,0" & $\mathrm{S}$ & $41029^{\prime} 15,0^{\prime \prime}$ \\
\hline RE-12 & Mucugê & QUARTZO & 13으어' 15,0" & $\mathrm{S}$ & $41030^{\prime} 45,0^{\prime \prime}$ \\
\hline RE-12 & Mucugê & QUARTZO & 13 o 02 ' 00,0" & $\mathrm{S}$ & $41^{\circ}=32^{\prime} 00,0^{\prime \prime}$ \\
\hline RE-12 & Mucugê & QUARTZO & 13 ㅇ 06 ' $37,0 "$ & $\mathrm{~S}$ & $41032^{\prime} 18,0^{\prime \prime}$ \\
\hline RE-12 & Mucugê & QUARTZO & 13으 05' 30,0" & $\mathrm{S}$ & $41^{\circ}=25^{\prime} 00,0^{\prime \prime}$ \\
\hline RE-12 & Mucugê & QUARTZO & 12 잉 $15,0^{\prime \prime}$ & $\mathrm{S}$ & $41030^{\prime} 50,0^{\prime \prime}$ \\
\hline RE-12 & Mucugê & QUARTZO & 13응' $15,0 "$ & $\mathrm{~S}$ & $41030^{\prime} 30,0^{\prime \prime}$ \\
\hline RE-12 & Mucugê & QUARTZO & 12 은 50, 50" & $\mathrm{S}$ & $41^{\circ} 35^{\prime} 00,0^{\prime \prime}$ \\
\hline RE-12 & Mucugê & QUARTZO & $12 \circ 42^{\prime} 45,0^{\prime \prime}$ & $\mathrm{s}$ & $41^{\circ}=33^{\prime} 45,0^{\prime \prime}$ \\
\hline RE-12 & Mucugê & QUARTZO & 12 o 43' 30,0" & $\mathrm{S}$ & $41031^{\prime} 30,0^{\prime \prime}$ \\
\hline RE-12 & Novo Horizonte & QUARTZO & $12 \circ 56^{\prime} 45,0^{\prime \prime}$ & $\mathrm{S}$ & $42^{\circ}=11^{\prime} 45,0^{\prime \prime}$ \\
\hline RE-12 & Novo Horizonte & QUARTZO & $12 \circ 57^{\prime} 45,0^{\prime \prime}$ & $\mathrm{S}$ & $42 \circ 10^{\prime} 15,0^{\prime \prime}$ \\
\hline RE-12 & Novo Horizonte & QUARTZO & 12 인 $15,0^{\prime \prime}$ & $\mathrm{S}$ & $42^{\circ} 08^{\prime} 00,0^{\prime \prime}$ \\
\hline RE-12 & Novo Horizonte & QUARTZO & 12 o 47' 17,0" & $\mathrm{S}$ & 42 ㅇ $12^{\prime} 58,0^{\prime \prime}$ \\
\hline RE-12 & Novo Horizonte & QUARTZO & $12 \circ 48^{\prime} 15,0^{\prime \prime}$ & $\mathrm{S}$ & $42^{\circ} 11^{\prime} 50,0^{\prime \prime}$ \\
\hline RE-12 & Novo Horizonte & QUARTZO & $12 \circ 57^{\prime} 15,0^{\prime \prime}$ & $\mathrm{s}$ & $42^{\circ} 09^{\prime} 15,0^{\prime \prime}$ \\
\hline RE-12 & Novo Horizonte & QUARTZO & 12 o 48' 14,0" & $\mathrm{S}$ & 42 은 $13^{\prime} 02,0^{\prime \prime}$ \\
\hline RE-12 & Novo Horizonte & QUARTZO & 12 ㅇ 48' 51,0" & $\mathrm{S}$ & $42^{\circ} 12^{\prime} 22,0^{\prime \prime}$ \\
\hline RE-12 & Novo Horizonte & QUARTZO & $12 \circ 46^{\prime} 27,0^{\prime \prime}$ & $\mathrm{S}$ & $42^{\circ}=10^{\prime} 25,0^{\prime \prime}$ \\
\hline RE-12 & Novo Horizonte & QUARTZO & 12 o 49' $08,0 "$ & $\mathrm{~s}$ & $42 \circ 11^{\prime} 48,0^{\prime \prime}$ \\
\hline $\mathrm{RE}-12$ & Novo Horizonte & QUARTZO & $12 \circ 50^{\prime} 31,0^{\prime \prime}$ & $\mathrm{S}$ & $42 \circ 13^{\prime} 31,0^{\prime \prime}$ \\
\hline RE-12 & Novo Horizonte & QUARTZO & 12 o 45' 00,0" & $\mathrm{S}$ & $42 \circ 13^{\prime} 00,0^{\prime \prime}$ \\
\hline $\mathrm{RE}-12$ & Novo Horizonte & QUARTZO & $12 \circ 46^{\prime} 40,0^{\prime \prime}$ & $\mathrm{S}$ & $42^{\circ}=13^{\prime} 30,0^{\prime \prime}$ \\
\hline RE-12 & Novo Horizonte & QUARTZO & $12 \circ 48^{\prime} 30,0 "$ & $\mathrm{~S}$ & $42^{\circ}=14^{\prime} 20,0^{\prime \prime}$ \\
\hline RE-12 & Novo Horizonte & QUARTZO & $12 \circ 47^{\prime} 10,0^{\prime \prime}$ & $\mathrm{s}$ & $42^{\circ} 13^{\prime} 00,0^{\prime \prime}$ \\
\hline RE-12 & Novo Horizonte & QUARTZO & $12 \circ 47^{\prime} 50,0^{\prime \prime}$ & $\mathrm{S}$ & $42^{\circ}=13^{\prime} 20,0^{\prime \prime}$ \\
\hline RE-12 & Novo Horizonte & QUARTZO & $12 \circ 47^{\prime} 50,0 "$ & $\mathrm{~S}$ & $42^{\circ}=12^{\prime} 50,0^{\prime \prime}$ \\
\hline RE-12 & Novo Horizonte & QUARTZO & 12 o 56' 07,1" & $\mathrm{S}$ & $42 \circ 10^{\prime} 00,0^{\prime \prime}$ \\
\hline RE-12 & Novo Horizonte & QUARTZO & 12 o 59' 20,0" & $\mathrm{S}$ & $42^{\circ} 07^{\prime} 20,0^{\prime \prime}$ \\
\hline RE-12 & Novo Horizonte & QUARTZO & $12 \circ 47^{\prime} 48,0^{\prime \prime}$ & $\mathrm{S}$ & $42^{\circ} 13^{\prime} 14,0^{\prime \prime}$ \\
\hline RE-12 & Novo Horizonte & QUARTZO & 12 o 45' 56,0" & $\mathrm{s}$ & $42^{\circ} 12^{\prime} 58,0^{\prime \prime}$ \\
\hline RE-12 & Novo Horizonte & QUARTZO & $12 \circ 47^{\prime} 50,0^{\prime \prime}$ & $\mathrm{s}$ & $42^{\circ} 13^{\prime} 40,0^{\prime \prime}$ \\
\hline RE-12 & Oliveira dos Brejinhos & QUARTZO & 12 o $18^{\prime} 24,0 "$ & $\mathrm{~S}$ & 42 일 $12,0^{\prime \prime}$ \\
\hline RE-12 & Oliveira dos Brejinhos & QUARTZO & $12 \circ 02^{\prime} 42,0 "$ & $\mathrm{~S}$ & $42^{\circ} 46^{\prime} 06,0^{\prime \prime}$ \\
\hline RE-12 & Oliveira dos Brejinhos & QUARTZO & $12^{\circ} 07^{\prime} 46,0^{\prime \prime}$ & $\mathrm{s}$ & $42^{\circ} 43^{\prime} 29,0^{\prime \prime}$ \\
\hline RE-12 & Oliveira dos Brejinhos & QUARTZO & 12 o $08^{\prime} 09,0 "$ & $\mathrm{~S}$ & $42 \circ 57^{\prime} 02,0^{\prime \prime}$ \\
\hline RE-12 & Oliveira dos Brejinhos & QUARTZO & 12 o 19' 30,0" & $\mathrm{S}$ & $42 \circ 55^{\prime} 12,0^{\prime \prime}$ \\
\hline RE-12 & Oliveira dos Brejinhos & QUARTZO & $12 \circ 14$ ' 18,0" & $\mathrm{S}$ & $42^{\circ} 23^{\prime} 00,0^{\prime \prime}$ \\
\hline RE-12 & Oliveira dos Brejinhos & QUARTZO & 12ㅇ 19' 10,0" & $\mathrm{S}$ & $42^{\circ}=55^{\prime} 34,0^{\prime \prime}$ \\
\hline RE-12 & Oliveira dos Brejinhos & QUARTZO & 12 o $13^{\prime} 53,0^{\prime \prime}$ & $\mathrm{S}$ & $42^{\circ}=56^{\prime} 06,0^{\prime \prime}$ \\
\hline RE-12 & Oliveira dos Brejinhos & QUARTZO & 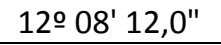 & $\mathrm{s}$ & $43 \circ 01^{\prime} 48,0^{\prime \prime}$ \\
\hline RE-12 & Oliveira dos Brejinhos & QUARTZO & 12 o $13^{\prime} 24,0 "$ & $\mathrm{~S}$ & $42^{\circ} 56^{\prime} 54,0^{\prime \prime}$ \\
\hline RE-12 & Oliveira dos Brejinhos & QUARTZO & $12^{\circ} 02^{\prime} 42,0^{\prime \prime}$ & $\mathrm{s}$ & 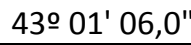 \\
\hline RE-12 & Oliveira dos Brejinhos & QUARTZO & $12 \circ 09$ ' $34,0 "$ & $\mathrm{~S}$ & $42 \circ 40^{\prime} 43,0^{\prime \prime}$ \\
\hline RE-12 & Oliveira dos Brejinhos & QUARTZO & 120 17' 48,0" & $\mathrm{s}$ & $42 \circ 55^{\prime} 48,0^{\prime \prime}$ \\
\hline
\end{tabular}




\begin{tabular}{|c|c|c|c|c|c|}
\hline RE-12 & Oliveira dos Brejinhos & QUARTZO & $12^{\circ} 18^{\prime} 36,0^{\prime \prime}$ & $\mathrm{s}$ & $42 \circ 55^{\prime} 36,0^{\prime \prime}$ \\
\hline RE-12 & Oliveira dos Brejinhos & QUARTZO & $12^{\circ} 03^{\prime} 45,0^{\prime \prime}$ & $\mathrm{s}$ & $42^{\circ}=42^{\prime} 02,0^{\prime \prime}$ \\
\hline $\mathrm{RE}-12$ & Palmeiras & QUARTZO & $12 \circ 42^{\prime} 45,0^{\prime \prime}$ & $\mathrm{S}$ & $41^{\circ} 36^{\prime} 00,0^{\prime \prime}$ \\
\hline $\mathrm{RE}-12$ & Palmeiras & QUARTZO & $12^{\circ} 38^{\prime} 05,0^{\prime \prime}$ & $\mathrm{S}$ & $41^{\circ} 35^{\prime} 30,0^{\prime \prime}$ \\
\hline RE-12 & Palmeiras & QUARTZO & $12 \circ 41^{\prime} 05,0^{\prime \prime}$ & $\mathrm{s}$ & $41^{\circ} 37^{\prime} 05,0^{\prime \prime}$ \\
\hline RE-12 & Paramirim & QUARTZO & $13027^{\prime} 33,0^{\prime \prime}$ & $\mathrm{s}$ & $42^{\circ}=12^{\prime} 24,0^{\prime \prime}$ \\
\hline RE-12 & Paramirim & QUARTZO & 13ㅇ $27^{\prime} 00,0^{\prime \prime}$ & $\mathrm{S}$ & $42^{\circ}=11^{\prime} 27,0^{\prime \prime}$ \\
\hline RE-12 & Piatã & QUARTZO & 13으언 $40,0^{\prime \prime}$ & $\mathrm{s}$ & $41044^{\prime} 40,0^{\prime \prime}$ \\
\hline RE-12 & Piatã & QUARTZO & $13008^{\prime} 00,0^{\prime \prime}$ & $\mathrm{s}$ & $41047^{\prime} 15,0^{\prime \prime}$ \\
\hline RE-12 & Piatã & QUARTZO & 13o $12^{\prime} 25,0^{\prime \prime}$ & $\mathrm{S}$ & $41^{\circ} 56^{\prime} 20,0^{\prime \prime}$ \\
\hline RE-12 & Piatã & QUARTZO & $13 \circ 05^{\prime} 29,0 "$ & $\mathrm{~s}$ & $41044^{\prime} 56,0^{\prime \prime}$ \\
\hline RE-12 & Seabra & QUARTZO & $12^{\circ} 41^{\prime} 00,0^{\prime \prime}$ & $\mathrm{s}$ & $41^{\circ} 56^{\prime} 00,0^{\prime \prime}$ \\
\hline RE-12 & Seabra & QUARTZO & $12 \circ 34^{\prime} 30,0^{\prime \prime}$ & $\mathrm{s}$ & $41^{\circ} 58^{\prime} 00,0^{\prime \prime}$ \\
\hline $\mathrm{RE}-12$ & Seabra & QUARTZO & $12 \circ 42^{\prime} 50,0^{\prime \prime}$ & $\mathrm{s}$ & 41 은 $05,0^{\prime \prime}$ \\
\hline RE-12 & Seabra & QUARTZO & $12928^{\prime} 30,0^{\prime \prime}$ & $\mathrm{s}$ & 41054 ' $15,0 "$ \\
\hline RE-12 & Seabra & QUARTZO & $12 \circ 20^{\prime} 45,0^{\prime \prime}$ & $\mathrm{s}$ & $41^{\circ} 48^{\prime} 30,0^{\prime \prime}$ \\
\hline RE-12 & Seabra & QUARTZO & $12^{\circ} 34^{\prime} 00,0^{\prime \prime}$ & $\mathrm{s}$ & $41^{\circ} 48^{\prime} 00,0^{\prime \prime}$ \\
\hline RE-12 & Seabra & QUARTZO & $12 \circ 28^{\prime} 50,0^{\prime \prime}$ & $\mathrm{s}$ & $41043^{\prime} 00,0^{\prime \prime}$ \\
\hline RE-12 & Seabra & QUARTZO & $12 \circ 29^{\prime} 05,0^{\prime \prime}$ & $\mathrm{s}$ & $41052^{\prime} 30,0^{\prime \prime}$ \\
\hline RE-12 & Seabra & QUARTZO & $12 \circ 44^{\prime} 30,0^{\prime \prime}$ & $\mathrm{s}$ & $42^{\circ} 00^{\prime} 30,0^{\prime \prime}$ \\
\hline RE-12 & Seabra & QUARTZO & $12 \circ 41^{\prime} 30,0^{\prime \prime}$ & $\mathrm{s}$ & $42 \div 00^{\prime} 30,0^{\prime \prime}$ \\
\hline RE-13 & Aracatu & QUARTZO & $14^{\circ} 28^{\prime} 31,1^{\prime \prime}$ & $\mathrm{S}$ & $41^{\circ} 21^{\prime} 44,1^{\prime \prime}$ \\
\hline RE-13 & Brumado & QUARTZO & $14^{\circ} 12^{\prime} 08,9^{\prime \prime}$ & $\mathrm{s}$ & $41^{\circ} 55^{\prime} 01,8^{\prime \prime}$ \\
\hline RE-13 & Caetité & QUARTZO & $14016^{\prime} 02,4^{\prime \prime}$ & $\mathrm{s}$ & $42^{\circ}=31^{\prime} 45,4^{\prime \prime}$ \\
\hline RE-13 & Cordeiros & QUARTZO & $15 \circ 07^{\prime} 50,0^{\prime \prime}$ & $\mathrm{S}$ & $42^{\circ} 00^{\prime} 00,0^{\prime \prime}$ \\
\hline RE-13 & Cordeiros & QUARTZO & $15 \circ 06^{\prime} 29,0 "$ & $\mathrm{~s}$ & 41은 $53^{\prime} 20,0^{\prime \prime}$ \\
\hline RE-13 & Cordeiros & QUARTZO & $15008^{\prime} 24,5^{\prime \prime}$ & $\mathrm{s}$ & $41054^{\prime} 13,9^{\prime \prime}$ \\
\hline RE-13 & Cordeiros & QUARTZO & $15008^{\prime} 28,8^{\prime \prime}$ & $\mathrm{s}$ & $41^{\circ} 54^{\prime} 47,3^{\prime \prime}$ \\
\hline RE-13 & Jacaraci & QUARTZO & $14055^{\prime} 58,0^{\prime \prime}$ & $\mathrm{s}$ & $42^{\circ} 27^{\prime} 30,0^{\prime \prime}$ \\
\hline RE-13 & $\begin{array}{l}\text { Livramento de Nossa } \\
\text { Senhora }\end{array}$ & QUARTZO & $13036^{\prime} 41,0^{\prime \prime}$ & $\mathrm{s}$ & $41056^{\prime} 52,0^{\prime \prime}$ \\
\hline RE-13 & $\begin{array}{l}\text { Livramento de Nossa } \\
\text { Senhora }\end{array}$ & QUARTZO & $13 \circ 36^{\prime} 52,3^{\prime \prime}$ & $\mathrm{s}$ & $41^{\circ} 56^{\prime} 57,3^{\prime \prime}$ \\
\hline RE-13 & $\begin{array}{l}\text { Livramento de Nossa } \\
\text { Senhora }\end{array}$ & QUARTZO & $13 \circ 35^{\prime} 43,0^{\prime \prime}$ & $\mathrm{s}$ & $41^{\circ} 58^{\prime} 47,0^{\prime \prime}$ \\
\hline $\mathrm{RE}-13$ & $\begin{array}{l}\text { Livramento de Nossa } \\
\text { Senhora }\end{array}$ & QUARTZO & $13035^{\prime} 22,0^{\prime \prime}$ & $\mathrm{s}$ & $42 \circ 00^{\prime} 51,0^{\prime \prime}$ \\
\hline RE-13 & $\begin{array}{l}\text { Livramento de Nossa } \\
\text { Senhora }\end{array}$ & QUARTZO & $13 \circ 34^{\prime} 13,5^{\prime \prime}$ & $\mathrm{s}$ & $41053^{\prime} 59,6 "$ \\
\hline RE-13 & $\begin{array}{l}\text { Livramento de Nossa } \\
\text { Senhora }\end{array}$ & QUARTZO & $13^{\circ} 33^{\prime} 56,9^{\prime \prime}$ & $\mathrm{s}$ & $41^{\circ} 55^{\prime} 03,2^{\prime \prime}$ \\
\hline RE-13 & $\begin{array}{l}\text { Livramento de Nossa } \\
\text { Senhora }\end{array}$ & QUARTZO & $14^{\circ} 06^{\prime} 50,3^{\prime \prime}$ & $\mathrm{s}$ & $42^{\circ} 01^{\prime} 10,9^{\prime \prime}$ \\
\hline RE-13 & $\begin{array}{l}\text { Livramento de Nossa } \\
\text { Senhora }\end{array}$ & QUARTZO & $13035^{\prime} 48,2^{\prime \prime}$ & $\mathrm{s}$ & $41^{\circ} 59^{\prime} 08,2^{\prime \prime}$ \\
\hline RE-13 & Palmas de Monte Alto & QUARTZO & $14^{\circ} 01^{\prime} 00,0^{\prime \prime}$ & $\mathrm{s}$ & 43ㅇ 10' 54,0" \\
\hline RE-13 & Rio do Antônio & QUARTZO & $14024^{\prime} 33,6^{\prime \prime}$ & $\mathrm{s}$ & $42^{\circ} 06^{\prime} 22,5^{\prime \prime}$ \\
\hline RE-13 & Sebastião Laranjeiras & QUARTZO & $14023^{\prime} 35,9^{\prime \prime}$ & $\mathrm{s}$ & $43-04$ ' $27,5^{\prime \prime}$ \\
\hline RE-13 & Sebastião Laranjeiras & QUARTZO & $14024^{\prime} 55,0^{\prime \prime}$ & $\mathrm{s}$ & $43-04^{\prime} 45,0 "$ \\
\hline RE-13 & Urandi & QUARTZO & $14050^{\prime} 22,7^{\prime \prime}$ & $\mathrm{s}$ & $42^{\circ}=34^{\prime} 50,2^{\prime \prime}$ \\
\hline RE-13 & Urandi & QUARTZO & $14041^{\prime} 09,0 "$ & $\mathrm{~s}$ & $42 \div 47^{\prime} 38,5^{\prime \prime}$ \\
\hline
\end{tabular}




\begin{tabular}{|c|c|c|c|c|c|}
\hline RE-14 & Barra & QUARTZO & $10 \circ 54^{\prime} 27,5^{\prime \prime}$ & $\mathrm{s}$ & 43으 $11^{\prime} 24,7^{\prime \prime}$ \\
\hline RE-14 & Barra & QUARTZO & $10050^{\prime} 58,0^{\prime \prime}$ & $\mathrm{s}$ & $43^{2} 08^{\prime} 11,6^{\prime \prime}$ \\
\hline RE-14 & Barra & QUARTZO & 11 언 $30,7 "$ & $\mathrm{~S}$ & $43026^{\prime} 07,9^{\prime \prime}$ \\
\hline RE-14 & Bom Jesus da Lapa & QUARTZO & 13 $20^{\prime} 45,0^{\prime \prime}$ & $\mathrm{S}$ & 43으일 $35,4^{\prime \prime}$ \\
\hline RE-14 & Morporá & QUARTZO & 11은 58' 29,3" & $\mathrm{s}$ & $43^{\circ} 05^{\prime} 16,9^{\prime \prime}$ \\
\hline RE-14 & Morporá & QUARTZO & 11으 $48^{\prime} 46,0^{\prime \prime}$ & $\mathrm{S}$ & $42^{\circ}=53^{\prime} 24,0^{\prime \prime}$ \\
\hline RE-14 & Paratinga & QUARTZO & 12 ㅇ 19' $36,0^{\prime \prime}$ & $\mathrm{S}$ & $42 \circ 58^{\prime} 38,0^{\prime \prime}$ \\
\hline RE-14 & Paratinga & QUARTZO & 12우 19' 40,0" & $\mathrm{S}$ & $42 \circ 56^{\prime} 10,0^{\prime \prime}$ \\
\hline RE-15 & Formosa do Rio Preto & QUARTZO & $11011^{\prime} 45,0 "$ & $\mathrm{~S}$ & $45 \circ 20^{\prime} 12,0^{\prime \prime}$ \\
\hline RE-15 & Formosa do Rio Preto & QUARTZO & 10 o 51' 53,4" & $\mathrm{S}$ & $45010^{\prime} 50,0^{\prime \prime}$ \\
\hline RE-15 & Mansidão & QUARTZO & 10 연 $17,0 "$ & $\mathrm{~S}$ & $44001^{\prime} 30,0^{\prime \prime}$ \\
\hline RE-15 & Santa Rita de Cássia & QUARTZO & $10043^{\prime} 14,0^{\prime \prime}$ & $\mathrm{S}$ & 440 - $11^{\prime} 58,0^{\prime \prime}$ \\
\hline RE-15 & Santa Rita de Cássia & QUARTZO & 10 언 $41^{\prime} 36,0 "$ & $\mathrm{~S}$ & $44022^{\prime} 33,0^{\prime \prime}$ \\
\hline RE-15 & Santa Rita de Cássia & QUARTZO & 10 은 40,0 ' & $\mathrm{S}$ & $44^{\circ} 29^{\prime} 10,0^{\prime \prime}$ \\
\hline RE-15 & Santa Rita de Cássia & QUARTZO & 10 어 $44^{\prime} 35,0^{\prime \prime}$ & $\mathrm{S}$ & 440 12' 06,0" \\
\hline RE-15 & Tabocas do Brejo Velho & QUARTZO & $12 \circ 34$ ' $02,3 "$ & $\mathrm{~s}$ & $44012^{\prime} 33,3^{\prime \prime}$ \\
\hline RE-03 & Amargosa & QUARTZO HIALINO & 13응 $42,1^{\prime \prime}$ & $\mathrm{S}$ & $39039^{\prime} 47,5^{\prime \prime}$ \\
\hline RE-03 & Brejões & QUARTZO HIALINO & 13으 03' 33,5" & $\mathrm{S}$ & $39045^{\prime} 50,3^{\prime \prime}$ \\
\hline RE-03 & Nova Itarana & QUARTZO HIALINO & 13 ㅇ $02^{\prime} 46,9^{\prime \prime}$ & $\mathrm{S}$ & $40007^{\prime} 23,8^{\prime \prime}$ \\
\hline RE-03 & Ubaíra & QUARTZO HIALINO & 13ㅇ 10' 15,7" & $\mathrm{s}$ & $39042^{\prime} 33,1^{\prime \prime}$ \\
\hline RE-03 & Ubaíra & QUARTZO HIALINO & 13 을 $15^{\prime} 23,8^{\prime \prime}$ & $\mathrm{S}$ & $39 \circ 40^{\prime} 42,7^{\prime \prime}$ \\
\hline RE-05 & Guaratinga & QUARTZO HIALINO & 16o 29' 53,1" & $\mathrm{S}$ & $39 \circ 47^{\prime} 40,4^{\prime \prime}$ \\
\hline RE-05 & Guaratinga & QUARTZO HIALINO & 16o $34^{\prime} 44,6 "$ & $\mathrm{~S}$ & $39047^{\prime} 14,5^{\prime \prime}$ \\
\hline RE-05 & Itamaraju & QUARTZO HIALINO & 16050 ' 50,6" & $\mathrm{S}$ & $39038^{\prime} 57,5^{\prime \prime}$ \\
\hline RE-06 & Canudos & QUARTZO HIALINO & 10 o $13^{\prime} 37,1^{\prime \prime}$ & $\mathrm{S}$ & $39015^{\prime} 31,3^{\prime \prime}$ \\
\hline RE-06 & Macururé & QUARTZO HIALINO & 09ㅇ 09' 06,8" & $\mathrm{S}$ & 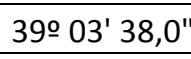 \\
\hline RE-06 & Monte Santo & QUARTZO HIALINO & $10^{\circ} 16^{\prime} 07,0^{\prime \prime}$ & $\mathrm{S}$ & $39037^{\prime} 42,0^{\prime \prime}$ \\
\hline RE-06 & Monte Santo & QUARTZO HIALINO & 10 o 35' 21,0" & $\mathrm{s}$ & $39 \circ 26^{\prime} 03,0^{\prime \prime}$ \\
\hline RE-06 & Monte Santo & QUARTZO HIALINO & $10 \circ 21^{\prime} 30,0^{\prime \prime}$ & $\mathrm{S}$ & $39 \circ 38^{\prime} 15,0^{\prime \prime}$ \\
\hline RE-06 & Monte Santo & QUARTZO HIALINO & 10 o 19' 50,0" & $\mathrm{s}$ & $39 \circ 39^{\prime} 30,0^{\prime \prime}$ \\
\hline RE-06 & Monte Santo & QUARTZO HIALINO & 100 19' 57,2" & $\mathrm{S}$ & $39038^{\prime} 49,9^{\prime \prime}$ \\
\hline RE-06 & Queimadas & QUARTZO HIALINO & 11 o 09' 44,0" & $\mathrm{s}$ & 390 58' 35, $0^{\prime \prime}$ \\
\hline RE-06 & Santa Luz & QUARTZO HIALINO & $11^{\circ} 15^{\prime} 17,0^{\prime \prime}$ & $\mathrm{s}$ & 39o $23^{\prime} 55,0^{\prime \prime}$ \\
\hline RE-06 & Uauá & QUARTZO HIALINO & 09은 44' 35,0" & $\mathrm{S}$ & $39036^{\prime} 52,0^{\prime \prime}$ \\
\hline RE-08 & Itambé & QUARTZO HIALINO & 15o $17^{\prime} 03,0^{\prime \prime}$ & $\mathrm{S}$ & $40 \circ 25^{\prime} 05,0^{\prime \prime}$ \\
\hline RE-08 & Jaguaquara & QUARTZO HIALINO & 13ㅇ 35' 40,1" & $\mathrm{S}$ & $39050^{\prime} 45,8^{\prime \prime}$ \\
\hline RE-08 & Jaguaquara & QUARTZO HIALINO & 13 ㅇ $20^{\prime} 50,5^{\prime \prime}$ & $\mathrm{S}$ & $40 \circ 03^{\prime} 36,3^{\prime \prime}$ \\
\hline RE-08 & Macarani & QUARTZO HIALINO & 15 ㅇ 25' 55,0" & $\mathrm{S}$ & $40026^{\prime} 11,0^{\prime \prime}$ \\
\hline RE-08 & Macarani & QUARTZO HIALINO & 15 - 24' 40,0" & $\mathrm{s}$ & $40026^{\prime} 25,0^{\prime \prime}$ \\
\hline RE-08 & Macarani & QUARTZO HIALINO & 15 ㅇ $37^{\prime} 07,0 "$ & $\mathrm{~S}$ & $40 \circ 28^{\prime} 07,0^{\prime \prime}$ \\
\hline RE-08 & Santa Inês & QUARTZO HIALINO & 13으 19' 15,0" & $\mathrm{S}$ & $39 \circ 50^{\prime} 50,0^{\prime \prime}$ \\
\hline RE-08 & Santa Inês & QUARTZO HIALINO & 13ㅇ $16^{\prime} 10,0^{\prime \prime}$ & $\mathrm{S}$ & 39o $48^{\prime} 30,0^{\prime \prime}$ \\
\hline RE-08 & Vitória da Conquista & QUARTZO HIALINO & 14 o 57' 18,0" & $\mathrm{S}$ & $41^{\circ}=08^{\prime} 00,0^{\prime \prime}$ \\
\hline RE-08 & Vitória da Conquista & QUARTZO HIALINO & 14 o $51^{\prime} 18,0^{\prime \prime}$ & $\mathrm{s}$ & $41^{\circ} 01^{\prime} 24,0^{\prime \prime}$ \\
\hline RE-08 & Vitória da Conquista & QUARTZO HIALINO & 14046 ' 22,0" & $\mathrm{S}$ & $40 \circ 57^{\prime} 35,0^{\prime \prime}$ \\
\hline RE-08 & Vitória da Conquista & QUARTZO HIALINO & 15 o $10^{\prime} 48,0^{\prime \prime}$ & $\mathrm{S}$ & $40051^{\prime} 12,0^{\prime \prime}$ \\
\hline RE-09 & Pilão Arcado & QUARTZO HIALINO & 09으 44' 49,8" & $\mathrm{S}$ & 43으 $33^{\prime} 10,0^{\prime \prime}$ \\
\hline RE-09 & Pilão Arcado & QUARTZO HIALINO & 09o 47' 34,4" & $\mathrm{s}$ & $42 \circ 40^{\prime} 29,1^{\prime \prime}$ \\
\hline RE-09 & Pilão Arcado & QUARTZO HIALINO & 09o 52' 53,0" & $\mathrm{s}$ & $42 \circ 43^{\prime} 36,9^{\prime \prime}$ \\
\hline RE-09 & Pilão Arcado & QUARTZO HIALINO & 09o 52' 55,7" & $\mathrm{S}$ & $42 \circ 43^{\prime} 39,4^{\prime \prime}$ \\
\hline
\end{tabular}




\begin{tabular}{|c|c|c|c|c|c|}
\hline RE-09 & Pilão Arcado & QUARTZO HIALINO & $09057^{\prime} 48,6^{\prime \prime}$ & $\mathrm{s}$ & $42 \circ 24^{\prime} 21,3^{\prime \prime}$ \\
\hline RE-09 & Pilão Arcado & QUARTZO HIALINO & $09052^{\prime} 11,9^{\prime \prime}$ & $\mathrm{s}$ & $42 \div 34^{\prime} 52,1^{\prime \prime}$ \\
\hline RE-09 & Pilão Arcado & QUARTZO HIALINO & 09o $48^{\prime} 30,8^{\prime \prime}$ & $\mathrm{S}$ & $42 \circ 36^{\prime} 54,0^{\prime \prime}$ \\
\hline RE-09 & Remanso & QUARTZO HIALINO & 09 44' 09,9" & $\mathrm{s}$ & $42^{\circ} 41^{\prime} 43,2^{\prime \prime}$ \\
\hline RE-11 & Barra do Mendes & QUARTZO HIALINO & 11은 58' 34,3" & $\mathrm{s}$ & $42 \circ 11^{\prime} 47,0^{\prime \prime}$ \\
\hline RE-12 & Brotas de Macaúbas & QUARTZO HIALINO & $12 \circ 01^{\prime} 14,5^{\prime \prime}$ & $\mathrm{S}$ & $42^{\circ}=14^{\prime} 00,9^{\prime \prime}$ \\
\hline RE-12 & Brotas de Macaúbas & QUARTZO HIALINO & 12 - $02^{\prime} 00,6^{\prime \prime}$ & $\mathrm{S}$ & $42 \circ 16^{\prime} 15,0^{\prime \prime}$ \\
\hline RE-12 & Brotas de Macaúbas & QUARTZO HIALINO & $12 \circ 01^{\prime} 36,6 "$ & $\mathrm{~s}$ & $42 \circ 16^{\prime} 12,5^{\prime \prime}$ \\
\hline RE-12 & Oliveira dos Brejinhos & QUARTZO HIALINO & $12 \circ 08^{\prime} 48,0^{\prime \prime}$ & $\mathrm{S}$ & $43 \circ 02^{\prime} 12,0^{\prime \prime}$ \\
\hline RE-12 & Oliveira dos Brejinhos & QUARTZO HIALINO & 12 응 $08^{\prime} 54,0 "$ & $\mathrm{~S}$ & $42^{\circ}=59^{\prime} 00,0^{\prime \prime}$ \\
\hline RE-12 & Oliveira dos Brejinhos & QUARTZO HIALINO & 12 o 09 ' 30,0" & $\mathrm{S}$ & $42 \circ 58^{\prime} 30,0^{\prime \prime}$ \\
\hline RE-12 & Oliveira dos Brejinhos & QUARTZO HIALINO & 12 o $10^{\prime} 00,0 "$ & $\mathrm{~S}$ & $42^{\circ}=57^{\prime} 37,0^{\prime \prime}$ \\
\hline RE-14 & Barra & QUARTZO HIALINO & 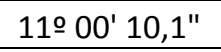 & $\mathrm{S}$ & $43025^{\prime} 19,8^{\prime \prime}$ \\
\hline RE-14 & Barra & QUARTZO HIALINO & $10055^{\prime} 19,0 "$ & $\mathrm{~s}$ & $43039^{\prime} 46,5^{\prime \prime}$ \\
\hline RE-14 & Barra & QUARTZO HIALINO & 11 o 03 ' 33,9" & $\mathrm{S}$ & 43을 24 ' 54,9" \\
\hline RE-14 & Bom Jesus da Lapa & QUARTZO HIALINO & 13ㅇ 19' 19,0" & $\mathrm{S}$ & $43 \circ 07^{\prime} 21,0^{\prime \prime}$ \\
\hline RE-14 & Bom Jesus da Lapa & QUARTZO HIALINO & 13으 18' 38,0" & $\mathrm{S}$ & $43 \circ 07^{\prime} 19,0^{\prime \prime}$ \\
\hline RE-14 & Ibotirama & QUARTZO HIALINO & 12 o $12^{\prime} 06,0^{\prime \prime}$ & $\mathrm{S}$ & 43으인 $30,0^{\prime \prime}$ \\
\hline RE-14 & Ibotirama & QUARTZO HIALINO & 12 o 14' 43,0" & $\mathrm{S}$ & 43으엉 $51,0^{\prime \prime}$ \\
\hline RE-14 & Ibotirama & QUARTZO HIALINO & 12ㅇ 11' 10,0" & $\mathrm{S}$ & $43^{\circ} 03^{\prime} 46,0^{\prime \prime}$ \\
\hline RE-14 & Morporá & QUARTZO HIALINO & 11046 '04,0" & $\mathrm{s}$ & $42^{\circ} 52^{\prime} 11,0^{\prime \prime}$ \\
\hline RE-14 & Morporá & QUARTZO HIALINO & 11 은 50,0" & $\mathrm{S}$ & $42^{\circ}=52^{\prime} 50,0^{\prime \prime}$ \\
\hline RE-14 & Morporá & QUARTZO HIALINO & 11 의 $46^{\prime} 20,0^{\prime \prime}$ & $\mathrm{S}$ & $42^{\circ}=56^{\prime} 55,0^{\prime \prime}$ \\
\hline RE-14 & Morporá & QUARTZO HIALINO & 11 o 44' 50,0" & $\mathrm{S}$ & $42^{\circ}=59^{\prime} 55,0^{\prime \prime}$ \\
\hline RE-14 & Morporá & QUARTZO HIALINO & 11은 40' 30,0" & $\mathrm{s}$ & $42 \circ 52^{\prime} 50,0^{\prime \prime}$ \\
\hline RE-14 & Paratinga & QUARTZO HIALINO & $12^{\circ} 13^{\prime} 24,0^{\prime \prime}$ & $\mathrm{s}$ & 43 응 $01^{\prime} 30,0^{\prime \prime}$ \\
\hline RE-14 & Paratinga & QUARTZO HIALINO & 12 o 30' 40,0" & $\mathrm{S}$ & 43은 $10^{\prime} 33,0^{\prime \prime}$ \\
\hline RE-14 & Paratinga & QUARTZO HIALINO & 12ㅇ 19' 40,4" & $\mathrm{s}$ & $42 \circ 56^{\prime} 09,7^{\prime \prime}$ \\
\hline RE-14 & Riacho de Santana & QUARTZO HIALINO & 13 o $20^{\prime} 54,0 "$ & $\mathrm{~s}$ & $43^{\circ} 06^{\prime} 00,0^{\prime \prime}$ \\
\hline RE-14 & Riacho de Santana & QUARTZO HIALINO & 13 o 20' 30,0" & $\mathrm{S}$ & 43으잉 $36,0^{\prime \prime}$ \\
\hline RE-14 & Riacho de Santana & QUARTZO HIALINO & $13 \div 20^{\prime} 30,0 "$ & $\mathrm{~S}$ & $43^{\circ} 06^{\prime} 24,0^{\prime \prime}$ \\
\hline RE-14 & Riacho de Santana & QUARTZO HIALINO & 13039 ' 30,0" & $\mathrm{S}$ & $42^{\circ}-47^{\prime} 19,0^{\prime \prime}$ \\
\hline RE-15 & Wanderley & QUARTZO HIALINO & 11은 49' 10,4" & $\mathrm{S}$ & $43 \div 52^{\prime} 49,8^{\prime \prime}$ \\
\hline RE-05 & Itapebi & QUARTZO LEITOSO & $15044^{\prime} 45,9 "$ & $\mathrm{~S}$ & 390 38' $31,5^{\prime \prime}$ \\
\hline RE-05 & Itapebi & QUARTZO LEITOSO & 150 49' 40,9" & $\mathrm{S}$ & $39041^{\prime} 35,7^{\prime \prime}$ \\
\hline RE-05 & Itapebi & QUARTZO LEITOSO & 15으 47' 00,3" & $\mathrm{S}$ & $39 \circ 40^{\prime} 27,4^{\prime \prime}$ \\
\hline RE-08 & Cândido Sales & QUARTZO ROSA & $15029^{\prime} 20,0 "$ & $\mathrm{~s}$ & $41^{\circ} 13^{\prime} 10,0^{\prime \prime}$ \\
\hline RE-08 & Cândido Sales & QUARTZO ROSA & 15 o 30' 20,0" & $\mathrm{S}$ & 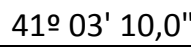 \\
\hline RE-08 & Encruzilhada & QUARTZO ROSA & $15 \circ 24^{\prime} 00,0 "$ & $\mathrm{~S}$ & $40055^{\prime} 15,0^{\prime \prime}$ \\
\hline RE-08 & Encruzilhada & QUARTZO ROSA & $15 \div 40$ ' 30,0" & $\mathrm{s}$ & $40 \circ 45^{\prime} 30,0^{\prime \prime}$ \\
\hline RE-08 & Encruzilhada & QUARTZO ROSA & 15o 31' 00,0" & $\mathrm{S}$ & 40 는 $53^{\prime} 50,0^{\prime \prime}$ \\
\hline RE-08 & Encruzilhada & QUARTZO ROSA & 15 o 33' 20,0" & $\mathrm{S}$ & 40 5 53' 40,0" \\
\hline RE-08 & Itambé & QUARTZO ROSA & 15 09' 40,0" & $\mathrm{S}$ & $40 \circ 44^{\prime} 50,0^{\prime \prime}$ \\
\hline RE-08 & Itambé & QUARTZO ROSA & $15 \circ 12^{\prime} 20,0^{\prime \prime}$ & $\mathrm{S}$ & $40041^{\prime} 50,0^{\prime \prime}$ \\
\hline RE-08 & Jequié & QUARTZO ROSA & 13은 55 00,0" & $\mathrm{s}$ & 40 인 $13^{\prime} 53,0^{\prime \prime}$ \\
\hline RE-08 & Lafayete Coutinho & QUARTZO ROSA & $13 \circ 35^{\prime} 00,0^{\prime \prime}$ & $\mathrm{s}$ & $40 \circ 13^{\prime} 53,0^{\prime \prime}$ \\
\hline RE-08 & Macarani & QUARTZO ROSA & 150 - 45' 20,0" & $\mathrm{S}$ & $40031^{\prime} 30,0^{\prime \prime}$ \\
\hline RE-08 & Macarani & QUARTZO ROSA & $15 \circ 35^{\prime} 44,0^{\prime \prime}$ & $\mathrm{s}$ & $40 \circ 25^{\prime} 39,0^{\prime \prime}$ \\
\hline RE-08 & Macarani & QUARTZO ROSA & 15ㅇ 24 ' $16,0^{\prime \prime}$ & $\mathrm{S}$ & $40^{\circ} 26^{\prime} 22,0^{\prime \prime}$ \\
\hline RE-08 & Macarani & QUARTZO ROSA & 15o $44^{\prime} 58,2^{\prime \prime}$ & $\mathrm{s}$ & $40 \cong 30^{\prime} 54,0^{\prime \prime}$ \\
\hline
\end{tabular}




\begin{tabular}{|c|c|c|c|c|c|}
\hline RE-08 & Manoel Vitorino & QUARTZO ROSA & $13 \circ 59^{\prime} 30,0^{\prime \prime}$ & $\mathrm{s}$ & $40 \circ 43^{\prime} 00,0^{\prime \prime}$ \\
\hline RE-08 & Mirante & QUARTZO ROSA & 14으이 $27,0^{\prime \prime}$ & $\mathrm{s}$ & $40 \circ 41^{\prime} 00,0^{\prime \prime}$ \\
\hline RE-08 & Mirante & QUARTZO ROSA & 14ㅇ 11' 54,0" & $\mathrm{S}$ & $40 \circ 43^{\prime} 06,0^{\prime \prime}$ \\
\hline RE-08 & Ribeirão do Largo & QUARTZO ROSA & 15029 ' $29,0 "$ & $\mathrm{~S}$ & $40043^{\prime} 30,0^{\prime \prime}$ \\
\hline RE-08 & Ribeirão do Largo & QUARTZO ROSA & $15028^{\prime} 00,0^{\prime \prime}$ & $\mathrm{s}$ & $40=45^{\prime} 30,0^{\prime \prime}$ \\
\hline RE-08 & Ribeirão do Largo & QUARTZO ROSA & 15 을 29 ' $20,0 "$ & $\mathrm{~S}$ & $40 \circ 43^{\prime} 00,0^{\prime \prime}$ \\
\hline RE-08 & Vitória da Conquista & QUARTZO ROSA & 15 o $20^{\prime} 16,0^{\prime \prime}$ & $\mathrm{S}$ & $40057^{\prime} 18,0^{\prime \prime}$ \\
\hline RE-09 & Juazeiro & QUARTZO RUTILADO & $09043^{\prime} 25,8^{\prime \prime}$ & $\mathrm{S}$ & $40043^{\prime} 16,3^{\prime \prime}$ \\
\hline RE-09 & Pilão Arcado & QUARTZO RUTILADO & $09052^{\prime} 58,0^{\prime \prime}$ & $\mathrm{s}$ & $42037^{\prime} 19,3^{\prime \prime}$ \\
\hline RE-09 & Pilão Arcado & QUARTZO RUTILADO & 09은 49' 38,4" & $\mathrm{S}$ & $42^{\circ}=37^{\prime} 22,6^{\prime \prime}$ \\
\hline RE-09 & Pilão Arcado & QUARTZO RUTILADO & 09으 51' 41,0" & $\mathrm{S}$ & $42^{\circ}=38^{\prime} 03,0^{\prime \prime}$ \\
\hline RE-12 & Ibipitanga & QUARTZO RUTILADO & $12 \circ 44^{\prime} 30,0^{\prime \prime}$ & $\mathrm{S}$ & $42^{\circ} 16^{\prime} 34,0^{\prime \prime}$ \\
\hline RE-12 & Novo Horizonte & QUARTZO RUTILADO & 12 o 50' $27,0^{\prime \prime}$ & $\mathrm{s}$ & $42^{\circ} 11^{\prime} 11,6^{\prime \prime}$ \\
\hline RE-12 & Novo Horizonte & QUARTZO RUTILADO & $12 \circ 44^{\prime} 47,0 "$ & $\mathrm{~S}$ & $42 \circ 10^{\prime} 55,0^{\prime \prime}$ \\
\hline RE-12 & Novo Horizonte & QUARTZO RUTILADO & $12046^{\prime} 48,0^{\prime \prime}$ & $\mathrm{s}$ & $42 \circ 10^{\prime} 07,0^{\prime \prime}$ \\
\hline RE-12 & Novo Horizonte & QUARTZO RUTILADO & 12 5 57' 52,0" & $\mathrm{S}$ & $42^{\circ} 08^{\prime} 26,0^{\prime \prime}$ \\
\hline RE-12 & Novo Horizonte & QUARTZO RUTILADO & $12 \circ 45^{\prime} 22,0^{\prime \prime}$ & $\mathrm{S}$ & $42^{\circ}=11^{\prime} 21,0^{\prime \prime}$ \\
\hline $\mathrm{RE}-12$ & Oliveira dos Brejinhos & QUARTZO RUTILADO & 12 을 $23^{\prime} 41,0 "$ & $\mathrm{~S}$ & $42^{\circ}=23^{\prime} 58,0^{\prime \prime}$ \\
\hline RE-14 & Paratinga & QUARTZO RUTILADO & 12 - 29' 53,0" & $\mathrm{S}$ & 43으잉 $07,3^{\prime \prime}$ \\
\hline RE-03 & Cabaceiras do Paraguaçu & QUARTZO/FELDSPATO & 12 o 37' 22,8" & $\mathrm{s}$ & 390 15' $20,6^{\prime \prime}$ \\
\hline RE-03 & Cabaceiras do Paraguaçu & QUARTZO/FELDSPATO & 12 을 $19,0 "$ & $\mathrm{~S}$ & $39015^{\prime} 11,1^{\prime \prime}$ \\
\hline RE-03 & Castro Alves & QUARTZO/FELDSPATO & 12 ㅇ 41' 14,2" & $\mathrm{S}$ & 39o $23^{\prime} 34,4^{\prime \prime}$ \\
\hline RE-03 & Castro Alves & QUARTZO/FELDSPATO & $12 \circ 46^{\prime} 34,5^{\prime \prime}$ & $\mathrm{S}$ & $39024^{\prime} 22,1^{\prime \prime}$ \\
\hline RE-03 & Castro Alves & QUARTZO/FELDSPATO & $12 \circ 43^{\prime} 40,6 "$ & $\mathrm{~S}$ & $39027^{\prime} 20,7^{\prime \prime}$ \\
\hline RE-03 & Castro Alves & QUARTZO/FELDSPATO & 12 은 $40,4 "$ & $\mathrm{~S}$ & $39 \circ 26^{\prime} 30,9^{\prime \prime}$ \\
\hline RE-03 & Castro Alves & QUARTZO/FELDSPATO & 12 o 39' 19,3" & $\mathrm{s}$ & $39 \circ 25^{\prime} 07,6^{\prime \prime}$ \\
\hline RE-03 & Castro Alves & QUARTZO/FELDSPATO & 12 영 $15,9^{\prime \prime}$ & $\mathrm{S}$ & $39021^{\prime} 18,5^{\prime \prime}$ \\
\hline RE-03 & Castro Alves & QUARTZO/FELDSPATO & $12042^{\prime} 33,9^{\prime \prime}$ & $\mathrm{s}$ & $39025^{\prime} 57,1^{\prime \prime}$ \\
\hline RE-03 & Castro Alves & QUARTZO/FELDSPATO & $12 \circ 40^{\prime} 21,4 "$ & $\mathrm{~S}$ & $39024^{\prime} 16,7^{\prime \prime}$ \\
\hline RE-03 & Castro Alves & QUARTZO/FELDSPATO & $12 \circ 38^{\prime} 41,0^{\prime \prime}$ & $\mathrm{S}$ & $39024^{\prime} 43,4^{\prime \prime}$ \\
\hline RE-03 & Castro Alves & QUARTZO/FELDSPATO & $12 \circ 46^{\prime} 29,7^{\prime \prime}$ & $\mathrm{S}$ & $39021^{\prime} 39,6^{\prime \prime}$ \\
\hline RE-03 & Castro Alves & QUARTZO/FELDSPATO & $12 \circ 46^{\prime} 27,2^{\prime \prime}$ & $\mathrm{s}$ & $39024^{\prime} 21,9^{\prime \prime}$ \\
\hline RE-03 & Castro Alves & QUARTZO/FELDSPATO & $12 \circ 46^{\prime} 22,5^{\prime \prime}$ & $\mathrm{S}$ & $39 \circ 20^{\prime} 26,1^{\prime \prime}$ \\
\hline RE-03 & Castro Alves & QUARTZO/FELDSPATO & $12042^{\prime} 59,2^{\prime \prime}$ & $\mathrm{s}$ & $39025^{\prime} 54,8^{\prime \prime}$ \\
\hline RE-03 & Castro Alves & QUARTZO/FELDSPATO & 12 영 $40^{\prime} 23,0^{\prime \prime}$ & $\mathrm{S}$ & 39ㅇ $22^{\prime} 08,7^{\prime \prime}$ \\
\hline RE-03 & Castro Alves & QUARTZO/FELDSPATO & $12037^{\prime} 18,8^{\prime \prime}$ & $\mathrm{s}$ & $39 \circ 22^{\prime} 45,3^{\prime \prime}$ \\
\hline RE-03 & Castro Alves & QUARTZO/FELDSPATO & 12 ㅇ $37^{\prime} 55,4^{\prime \prime}$ & $\mathrm{S}$ & $39 \circ 24^{\prime} 50,0^{\prime \prime}$ \\
\hline RE-03 & Castro Alves & QUARTZO/FELDSPATO & 12 일 $31,1^{\prime \prime}$ & $\mathrm{S}$ & $39025^{\prime} 05,7^{\prime \prime}$ \\
\hline RE-03 & Castro Alves & QUARTZO/FELDSPATO & 12 - 37' 40,5" & $\mathrm{s}$ & $39024^{\prime} 47,7^{\prime \prime}$ \\
\hline RE-03 & Castro Alves & QUARTZO/FELDSPATO & $12 \circ 37^{\prime} 49,9 "$ & $\mathrm{~S}$ & $39 \circ 24^{\prime} 26,4^{\prime \prime}$ \\
\hline RE-03 & Castro Alves & QUARTZO/FELDSPATO & 12 ㅇ $38^{\prime} 17,2^{\prime \prime}$ & $\mathrm{S}$ & $39024^{\prime} 32,4^{\prime \prime}$ \\
\hline RE-03 & Castro Alves & QUARTZO/FELDSPATO & 12 ㅇ 38' 05,8" & $\mathrm{S}$ & 39ㅇ $24^{\prime} 42,4^{\prime \prime}$ \\
\hline RE-03 & Castro Alves & QUARTZO/FELDSPATO & $12041^{\prime} 24,3^{\prime \prime}$ & $\mathrm{S}$ & $39 \circ 20^{\prime} 37,0^{\prime \prime}$ \\
\hline RE-03 & Castro Alves & QUARTZO/FELDSPATO & $12 \circ 37^{\prime} 06,1^{\prime \prime}$ & $\mathrm{S}$ & 39o $22^{\prime} 39,4^{\prime \prime}$ \\
\hline RE-03 & Castro Alves & QUARTZO/FELDSPATO & $12 \circ 37^{\prime} 42,2^{\prime \prime}$ & $\mathrm{S}$ & 39을 $20^{\prime} 31,7^{\prime \prime}$ \\
\hline RE-03 & Castro Alves & QUARTZO/FELDSPATO & 12 - 37' 22,0" & $\mathrm{S}$ & $39020^{\prime} 28,3^{\prime \prime}$ \\
\hline RE-03 & Castro Alves & QUARTZO/FELDSPATO & $12037^{\prime} 11,5^{\prime \prime}$ & $\mathrm{s}$ & $39 \circ 20^{\prime} 48,9^{\prime \prime}$ \\
\hline RE-03 & Castro Alves & QUARTZO/FELDSPATO & $12 \div 38^{\prime} 49,4^{\prime \prime}$ & $\mathrm{s}$ & $39025^{\prime} 10,8^{\prime \prime}$ \\
\hline RE-03 & Castro Alves & QUARTZO/FELDSPATO & 12 ㅇ 39' $44,7^{\prime \prime}$ & $\mathrm{S}$ & $39026^{\prime} 03,8^{\prime \prime}$ \\
\hline RE-03 & Castro Alves & QUARTZO/FELDSPATO & 12 o 48' 02,1" & $\mathrm{s}$ & $39 \circ 26^{\prime} 25,2^{\prime \prime}$ \\
\hline
\end{tabular}




\begin{tabular}{|c|c|c|c|c|c|}
\hline RE-03 & Castro Alves & QUARTZO/FELDSPATO & $12 \circ 49^{\prime} 28,0 "$ & $\mathrm{~s}$ & $39025^{\prime} 11,4^{\prime \prime}$ \\
\hline RE-03 & Castro Alves & QUARTZO/FELDSPATO & 12 o 51' 42,0" & $\mathrm{S}$ & 39o 24 ' 47,9" \\
\hline RE-03 & Castro Alves & QUARTZO/FELDSPATO & 12 - 40' 20,6" & $\mathrm{S}$ & 39o $18^{\prime} 38,0^{\prime \prime}$ \\
\hline RE-03 & Castro Alves & QUARTZO/FELDSPATO & $12 \circ 39^{\prime} 53,3 "$ & $\mathrm{~S}$ & $39018^{\prime} 55,2^{\prime \prime}$ \\
\hline RE-03 & Castro Alves & QUARTZO/FELDSPATO & $12 \circ 40$ ' $07,4 "$ & $\mathrm{~s}$ & 390 18' $36,8^{\prime \prime}$ \\
\hline RE-03 & Castro Alves & QUARTZO/FELDSPATO & 12은 49' 59,4" & $\mathrm{S}$ & $39016^{\prime} 09,8^{\prime \prime}$ \\
\hline RE-03 & Castro Alves & QUARTZO/FELDSPATO & 12 - 47' 34,7" & $\mathrm{S}$ & 390 18' 42,4" \\
\hline RE-03 & Castro Alves & QUARTZO/FELDSPATO & 12 o 49' 03,8" & $\mathrm{S}$ & $39021^{\prime} 58,9^{\prime \prime}$ \\
\hline RE-03 & Castro Alves & QUARTZO/FELDSPATO & $12 \circ 47^{\prime} 41,7^{\prime \prime}$ & $\mathrm{S}$ & $39 \circ 21^{\prime} 56,2^{\prime \prime}$ \\
\hline RE-03 & Castro Alves & QUARTZO/FELDSPATO & $12 \circ 47^{\prime} 51,5^{\prime \prime}$ & $\mathrm{S}$ & $39022^{\prime} 28,3^{\prime \prime}$ \\
\hline RE-03 & Castro Alves & QUARTZO/FELDSPATO & $12 \circ 45^{\prime} 51,0 "$ & $\mathrm{~S}$ & 39ㅇ $26^{\prime} 51,7^{\prime \prime}$ \\
\hline RE-03 & Castro Alves & QUARTZO/FELDSPATO & 12 o 41' 29,1" & $\mathrm{S}$ & $39023^{\prime} 23,3^{\prime \prime}$ \\
\hline RE-03 & Castro Alves & QUARTZO/FELDSPATO & 12ㅇ 41' 09,6" & $\mathrm{S}$ & $39 \circ 23^{\prime} 27,7^{\prime \prime}$ \\
\hline RE-03 & Castro Alves & QUARTZO/FELDSPATO & 12 o 40' 59,6" & $\mathrm{S}$ & $39023^{\prime} 24,3^{\prime \prime}$ \\
\hline RE-03 & Castro Alves & QUARTZO/FELDSPATO & $12 \circ 46^{\prime} 47,4^{\prime \prime}$ & $\mathrm{S}$ & $39023^{\prime} 14,9^{\prime \prime}$ \\
\hline RE-03 & Castro Alves & QUARTZO/FELDSPATO & $12 \circ 46^{\prime} 47,6^{\prime \prime}$ & $\mathrm{S}$ & $39 \circ 23^{\prime} 27,4^{\prime \prime}$ \\
\hline RE-03 & Castro Alves & QUARTZO/FELDSPATO & 12 o 46' 58,0" & $\mathrm{S}$ & $39023^{\prime} 21,1^{\prime \prime}$ \\
\hline RE-03 & Castro Alves & QUARTZO/FELDSPATO & $12048^{\prime} 18,8^{\prime \prime}$ & $\mathrm{S}$ & 39o $25^{\prime} 39,9^{\prime \prime}$ \\
\hline RE-03 & Castro Alves & QUARTZO/FELDSPATO & $12044^{\prime} 38,2 "$ & $\mathrm{~S}$ & $39028^{\prime} 25,8^{\prime \prime}$ \\
\hline RE-03 & Castro Alves & QUARTZO/FELDSPATO & 12 ㅇ 44' 40,1" & $\mathrm{s}$ & $39028^{\prime} 22,2^{\prime \prime}$ \\
\hline RE-03 & Castro Alves & QUARTZO/FELDSPATO & $12048^{\prime} 11,3^{\prime \prime}$ & $\mathrm{S}$ & $39026^{\prime} 18,7^{\prime \prime}$ \\
\hline RE-03 & Castro Alves & QUARTZO/FELDSPATO & $12 \circ 45^{\prime} 00,2^{\prime \prime}$ & $\mathrm{S}$ & $39028^{\prime} 13,6^{\prime \prime}$ \\
\hline RE-03 & Castro Alves & QUARTZO/FELDSPATO & $12 \circ 51^{\prime} 43,7^{\prime \prime}$ & $\mathrm{s}$ & $39 \circ 24^{\prime} 49,0^{\prime \prime}$ \\
\hline RE-03 & Castro Alves & QUARTZO/FELDSPATO & $12 \circ 40$ ' 17,2" & $\mathrm{S}$ & $39023^{\prime} 14,7^{\prime \prime}$ \\
\hline RE-03 & Castro Alves & QUARTZO/FELDSPATO & 12 o $38^{\prime} 44,1^{\prime \prime}$ & $\mathrm{s}$ & $39 \circ 24^{\prime} 08,2^{\prime \prime}$ \\
\hline RE-03 & Castro Alves & QUARTZO/FELDSPATO & $12 \circ 38^{\prime} 40,7^{\prime \prime}$ & $\mathrm{S}$ & $39 \circ 24^{\prime} 06,9^{\prime \prime}$ \\
\hline RE-03 & Castro Alves & QUARTZO/FELDSPATO & $12^{\circ} 38^{\prime} 47,6 "$ & $\mathrm{~S}$ & 39ㅇ 23' 58,0" \\
\hline RE-03 & Castro Alves & QUARTZO/FELDSPATO & 12 o $38^{\prime} 48,0^{\prime \prime}$ & $\mathrm{s}$ & $39023^{\prime} 04,8^{\prime \prime}$ \\
\hline RE-03 & Castro Alves & QUARTZO/FELDSPATO & $12 \circ 38^{\prime} 26,5^{\prime \prime}$ & $\mathrm{S}$ & $39 \circ 23^{\prime} 27,5^{\prime \prime}$ \\
\hline RE-03 & Castro Alves & QUARTZO/FELDSPATO & $12038^{\prime} 12,8^{\prime \prime}$ & $\mathrm{S}$ & 39o $23^{\prime} 34,1^{\prime \prime}$ \\
\hline RE-03 & Castro Alves & QUARTZO/FELDSPATO & 12 o 39' 50,9" & $\mathrm{s}$ & $39 \circ 24$ ' $26,7^{\prime \prime}$ \\
\hline RE-03 & Castro Alves & QUARTZO/FELDSPATO & 12 o $39^{\prime} 27,6^{\prime \prime}$ & $\mathrm{S}$ & 39024 ' $18,3^{\prime \prime}$ \\
\hline RE-03 & Castro Alves & QUARTZO/FELDSPATO & 12 o 39' $38,5^{\prime \prime}$ & $\mathrm{S}$ & 39024 ' $27,1^{\prime \prime}$ \\
\hline RE-03 & Castro Alves & QUARTZO/FELDSPATO & 12 o 40' $34,7^{\prime \prime}$ & $\mathrm{S}$ & 39o 24 ' $34,3^{\prime \prime}$ \\
\hline RE-03 & Castro Alves & QUARTZO/FELDSPATO & $12^{\circ} 36^{\prime} 58,8^{\prime \prime}$ & $\mathrm{S}$ & 390 16' 49,3" \\
\hline RE-03 & Castro Alves & QUARTZO/FELDSPATO & 12 o $37^{\prime} 01,4^{\prime \prime}$ & $\mathrm{S}$ & $39016^{\prime} 58,8^{\prime \prime}$ \\
\hline RE-03 & Castro Alves & QUARTZO/FELDSPATO & 12 일 $21,6^{\prime \prime}$ & $\mathrm{s}$ & $39025^{\prime} 55,5^{\prime \prime}$ \\
\hline RE-03 & Castro Alves & QUARTZO/FELDSPATO & 12 o $37^{\prime} 43,2^{\prime \prime}$ & $\mathrm{s}$ & 39o 24 ' 11,4" \\
\hline RE-03 & Castro Alves & QUARTZO/FELDSPATO & $12 \circ 44^{\prime} 47,4^{\prime \prime}$ & $\mathrm{S}$ & $39026^{\prime} 42,2^{\prime \prime}$ \\
\hline RE-03 & Castro Alves & QUARTZO/FELDSPATO & $12 \circ 42^{\prime} 48,8^{\prime \prime}$ & $\mathrm{S}$ & 39o $22^{\prime} 16,9^{\prime \prime}$ \\
\hline RE-03 & Castro Alves & QUARTZO/FELDSPATO & 12 o 50' 30,0" & $\mathrm{S}$ & $39020^{\prime} 58,5^{\prime \prime}$ \\
\hline RE-03 & Castro Alves & QUARTZO/FELDSPATO & 12 o 50' $30,8^{\prime \prime}$ & $\mathrm{S}$ & $39021^{\prime} 02,1^{\prime \prime}$ \\
\hline RE-03 & Castro Alves & QUARTZO/FELDSPATO & $12 \circ 50$ ' 25,4" & $\mathrm{S}$ & $39020^{\prime} 57,8^{\prime \prime}$ \\
\hline RE-03 & Castro Alves & QUARTZO/FELDSPATO & $12 \circ 44^{\prime} 22,5^{\prime \prime}$ & $\mathrm{S}$ & 39o 29 ' $18,4^{\prime \prime}$ \\
\hline RE-03 & Castro Alves & QUARTZO/FELDSPATO & $12 \circ 43^{\prime} 45,7^{\prime \prime}$ & $\mathrm{S}$ & $39027^{\prime} 14,4^{\prime \prime}$ \\
\hline RE-03 & Castro Alves & QUARTZO/FELDSPATO & $12 \circ 43^{\prime} 14,8 "$ & $\mathrm{~s}$ & $39027^{\prime} 13,4^{\prime \prime}$ \\
\hline RE-03 & Castro Alves & QUARTZO/FELDSPATO & $12 \circ 43^{\prime} 22,4^{\prime \prime}$ & $\mathrm{S}$ & $39 \circ 27^{\prime} 02,0^{\prime \prime}$ \\
\hline RE-03 & Castro Alves & QUARTZO/FELDSPATO & 12 o $43^{\prime} 23,5^{\prime \prime}$ & $\mathrm{s}$ & $39 \circ 26^{\prime} 54,0^{\prime \prime}$ \\
\hline RE-03 & Castro Alves & QUARTZO/FELDSPATO & 12 o 43' 30,7" & $\mathrm{S}$ & 39ㅇ $26^{\prime} 47,1^{\prime \prime}$ \\
\hline RE-03 & Castro Alves & QUARTZO/FELDSPATO & $12 \circ 44^{\prime} 21,2^{\prime \prime}$ & $\mathrm{s}$ & 39o 21' 33,9" \\
\hline
\end{tabular}




\begin{tabular}{|c|c|c|c|c|c|}
\hline RE-03 & Castro Alves & QUARTZO/FELDSPATO & 12 ㅇ' $10,9 "$ & $\mathrm{~s}$ & 39ㅇ $23^{\prime} 02,4^{\prime \prime}$ \\
\hline RE-03 & Castro Alves & QUARTZO/FELDSPATO & 12 ㅇ' $13,1^{\prime \prime}$ & $\mathrm{S}$ & $39022^{\prime} 58,2^{\prime \prime}$ \\
\hline RE-03 & Castro Alves & QUARTZO/FELDSPATO & $12 \circ 44^{\prime} 48,0 "$ & $\mathrm{~S}$ & 39o $22^{\prime} 32,7^{\prime \prime}$ \\
\hline RE-03 & Castro Alves & QUARTZO/FELDSPATO & $12 \circ 40^{\prime} 06,2^{\prime \prime}$ & $\mathrm{S}$ & $39022^{\prime} 15,9^{\prime \prime}$ \\
\hline RE-03 & Castro Alves & QUARTZO/FELDSPATO & $12 \circ 39^{\prime} 03,8 "$ & $\mathrm{~s}$ & $39024^{\prime} 26,7^{\prime \prime}$ \\
\hline RE-03 & Castro Alves & QUARTZO/FELDSPATO & $12 \circ 38^{\prime} 52,2^{\prime \prime}$ & $\mathrm{S}$ & $39 \circ 24^{\prime} 40,8^{\prime \prime}$ \\
\hline RE-03 & Castro Alves & QUARTZO/FELDSPATO & 12 o 39' 18,7" & $\mathrm{S}$ & $39025^{\prime} 21,6^{\prime \prime}$ \\
\hline RE-03 & Castro Alves & QUARTZO/FELDSPATO & 12 o $36^{\prime} 36,7^{\prime \prime}$ & $\mathrm{S}$ & 39ㅇ $22^{\prime} 05,7^{\prime \prime}$ \\
\hline RE-03 & Castro Alves & QUARTZO/FELDSPATO & $12 \circ 36^{\prime} 19,4^{\prime \prime}$ & $\mathrm{S}$ & $39 \circ 21^{\prime} 40,8^{\prime \prime}$ \\
\hline RE-03 & Castro Alves & QUARTZO/FELDSPATO & 12 o 39' 00,6" & $\mathrm{s}$ & $39 \circ 15^{\prime} 00,2^{\prime \prime}$ \\
\hline RE-03 & Castro Alves & QUARTZO/FELDSPATO & $12047^{\prime} 31,9 "$ & $\mathrm{~S}$ & $39025^{\prime} 08,2^{\prime \prime}$ \\
\hline RE-03 & Castro Alves & QUARTZO/FELDSPATO & $12 \circ 36^{\prime} 05,6^{\prime \prime}$ & $\mathrm{S}$ & $39 \circ 23^{\prime} 08,6^{\prime \prime}$ \\
\hline RE-03 & Castro Alves & QUARTZO/FELDSPATO & $12 \circ 36^{\prime} 32,5^{\prime \prime}$ & $\mathrm{S}$ & $39 \circ 22^{\prime} 11,2^{\prime \prime}$ \\
\hline RE-03 & Castro Alves & QUARTZO/FELDSPATO & $12036^{\prime} 41,2^{\prime \prime}$ & $\mathrm{S}$ & 39o $22^{\prime} 10,0^{\prime \prime}$ \\
\hline RE-03 & Castro Alves & QUARTZO/FELDSPATO & $12036^{\prime} 49,6^{\prime \prime}$ & $\mathrm{S}$ & 39o $22^{\prime} 49,8^{\prime \prime}$ \\
\hline RE-03 & Castro Alves & QUARTZO/FELDSPATO & $12 \circ 39^{\prime} 48,8^{\prime \prime}$ & $\mathrm{S}$ & $39 \circ 25^{\prime} 51,0^{\prime \prime}$ \\
\hline RE-03 & Castro Alves & QUARTZO/FELDSPATO & 12 o $39^{\prime} 40,2^{\prime \prime}$ & $\mathrm{S}$ & $39 \circ 25^{\prime} 56,3^{\prime \prime}$ \\
\hline RE-03 & Castro Alves & QUARTZO/FELDSPATO & 12 o 39' 37,1" & $\mathrm{S}$ & $39026^{\prime} 13,9^{\prime \prime}$ \\
\hline RE-03 & Castro Alves & QUARTZO/FELDSPATO & 12 o 38' 52,6" & $\mathrm{S}$ & $39026^{\prime} 00,3^{\prime \prime}$ \\
\hline RE-03 & Castro Alves & QUARTZO/FELDSPATO & 12 은 50' 19,6" & $\mathrm{s}$ & 39-22' 12,0" \\
\hline RE-03 & Castro Alves & QUARTZO/FELDSPATO & 12 어 $48^{\prime} 38,7^{\prime \prime}$ & $\mathrm{S}$ & $39024^{\prime} 18,0^{\prime \prime}$ \\
\hline RE-03 & Castro Alves & QUARTZO/FELDSPATO & $12 \circ 44^{\prime} 28,5^{\prime \prime}$ & $\mathrm{S}$ & $39026^{\prime} 44,8^{\prime \prime}$ \\
\hline RE-03 & Castro Alves & QUARTZO/FELDSPATO & $12 \circ 44^{\prime} 16,3^{\prime \prime}$ & $\mathrm{S}$ & $39026^{\prime} 47,5^{\prime \prime}$ \\
\hline RE-03 & Castro Alves & QUARTZO/FELDSPATO & $12 \circ 44^{\prime} 24,5^{\prime \prime}$ & $\mathrm{S}$ & $39026^{\prime} 37,0^{\prime \prime}$ \\
\hline RE-03 & Castro Alves & QUARTZO/FELDSPATO & 12 어 $44^{\prime} 07,5^{\prime \prime}$ & $\mathrm{S}$ & $39026^{\prime} 48,2^{\prime \prime}$ \\
\hline RE-03 & Castro Alves & QUARTZO/FELDSPATO & 12 언 $59,7 "$ & $\mathrm{~S}$ & $39026^{\prime} 56,2^{\prime \prime}$ \\
\hline RE-03 & Castro Alves & QUARTZO/FELDSPATO & $12 \circ 43^{\prime} 50,0^{\prime \prime}$ & $\mathrm{S}$ & $39027^{\prime} 42,8^{\prime \prime}$ \\
\hline RE-03 & Castro Alves & QUARTZO/FELDSPATO & $12 \circ 45^{\prime} 41,4^{\prime \prime}$ & $\mathrm{s}$ & $39 \circ 20^{\prime} 28,3^{\prime \prime}$ \\
\hline RE-03 & Castro Alves & QUARTZO/FELDSPATO & $12 \circ 42^{\prime} 56,9^{\prime \prime}$ & $\mathrm{S}$ & $39025^{\prime} 59,9^{\prime \prime}$ \\
\hline RE-03 & Castro Alves & QUARTZO/FELDSPATO & $12037^{\prime} 48,9^{\prime \prime}$ & $\mathrm{S}$ & 39o 17 ' $39,7^{\prime \prime}$ \\
\hline RE-03 & Castro Alves & QUARTZO/FELDSPATO & $12 \circ 37^{\prime} 47,1^{\prime \prime}$ & $\mathrm{S}$ & $39017^{\prime} 49,6^{\prime \prime}$ \\
\hline RE-03 & Castro Alves & QUARTZO/FELDSPATO & $12^{\circ} 37^{\prime} 51,6 "$ & $\mathrm{~s}$ & $39018^{\prime} 06,3^{\prime \prime}$ \\
\hline RE-03 & Castro Alves & QUARTZO/FELDSPATO & $12 \circ 42^{\prime} 15,7^{\prime \prime}$ & $\mathrm{S}$ & $39 \circ 28^{\prime} 02,5^{\prime \prime}$ \\
\hline RE-03 & Castro Alves & QUARTZO/FELDSPATO & 12 - $42^{\prime} 00,2^{\prime \prime}$ & $\mathrm{S}$ & $39027^{\prime} 24,8^{\prime \prime}$ \\
\hline RE-03 & Castro Alves & QUARTZO/FELDSPATO & $12 \circ 41^{\prime} 54,0 "$ & $\mathrm{~S}$ & $39026^{\prime} 59,0^{\prime \prime}$ \\
\hline RE-03 & Castro Alves & QUARTZO/FELDSPATO & $122^{\circ} 42^{\prime} 08,3^{\prime \prime}$ & $\mathrm{s}$ & $39026^{\prime} 51,8^{\prime \prime}$ \\
\hline RE-03 & Castro Alves & QUARTZO/FELDSPATO & $12 \circ 42^{\prime} 10,9^{\prime \prime}$ & $\mathrm{s}$ & $39026^{\prime} 55,5^{\prime \prime}$ \\
\hline RE-03 & Castro Alves & QUARTZO/FELDSPATO & 12 o 47' 21,5" & $\mathrm{s}$ & $39025^{\prime} 06,7^{\prime \prime}$ \\
\hline RE-03 & Castro Alves & QUARTZO/FELDSPATO & $12047^{\prime} 15,8^{\prime \prime}$ & $\mathrm{S}$ & $39025^{\prime} 13,4^{\prime \prime}$ \\
\hline RE-03 & Castro Alves & QUARTZO/FELDSPATO & 12 o $37^{\prime} 33,3^{\prime \prime}$ & $\mathrm{S}$ & $39017^{\prime} 27,8^{\prime \prime}$ \\
\hline RE-03 & Castro Alves & QUARTZO/FELDSPATO & $12 \circ 47^{\prime} 22,2^{\prime \prime}$ & $\mathrm{S}$ & $39025^{\prime} 49,7^{\prime \prime}$ \\
\hline RE-03 & Castro Alves & QUARTZO/FELDSPATO & $12044^{\prime} 12,7^{\prime \prime}$ & $\mathrm{S}$ & $39026^{\prime} 34,5^{\prime \prime}$ \\
\hline RE-03 & Castro Alves & QUARTZO/FELDSPATO & $12 \circ 44^{\prime} 45,3^{\prime \prime}$ & $\mathrm{S}$ & $39028^{\prime} 19,4^{\prime \prime}$ \\
\hline RE-03 & Castro Alves & QUARTZO/FELDSPATO & $12 \circ 44^{\prime} 51,3^{\prime \prime}$ & $\mathrm{S}$ & $39028^{\prime} 12,2^{\prime \prime}$ \\
\hline RE-03 & Castro Alves & QUARTZO/FELDSPATO & $12 \circ 48^{\prime} 14,1^{\prime \prime}$ & $\mathrm{S}$ & $39023^{\prime} 12,2^{\prime \prime}$ \\
\hline RE-03 & Castro Alves & QUARTZO/FELDSPATO & $12 \circ 48$ '02,3" & $\mathrm{s}$ & $39023^{\prime} 23,8^{\prime \prime}$ \\
\hline RE-03 & Castro Alves & QUARTZO/FELDSPATO & $12 \circ 47^{\prime} 46,5^{\prime \prime}$ & $\mathrm{S}$ & $39023^{\prime} 26,4^{\prime \prime}$ \\
\hline RE-03 & Castro Alves & QUARTZO/FELDSPATO & 12 o 41' 20,3" & $\mathrm{s}$ & $39 \circ 26^{\prime} 09,1^{\prime \prime}$ \\
\hline RE-03 & Castro Alves & QUARTZO/FELDSPATO & 12 o 40' 59,3" & $\mathrm{S}$ & 39ㅇ $26^{\prime} 11,9^{\prime \prime}$ \\
\hline RE-03 & Castro Alves & QUARTZO/FELDSPATO & 12 o 41' 00,5" & $\mathrm{S}$ & $39026^{\prime} 15,7^{\prime \prime}$ \\
\hline
\end{tabular}




\begin{tabular}{|c|c|c|c|c|c|}
\hline RE-03 & Castro Alves & QUARTZO/FELDSPATO & $12 \circ 35^{\prime} 50,2^{\prime \prime}$ & $\mathrm{S}$ & $39 \circ 21^{\prime} 24,7^{\prime \prime}$ \\
\hline RE-03 & Castro Alves & QUARTZO/FELDSPATO & 12 o 44' 59,4" & $\mathrm{s}$ & $39-26^{\prime} 17,4^{\prime \prime}$ \\
\hline RE-03 & Castro Alves & QUARTZO/FELDSPATO & 12 - 36' $36,2^{\prime \prime}$ & $\mathrm{S}$ & $39018^{\prime} 19,2^{\prime \prime}$ \\
\hline RE-03 & Castro Alves & QUARTZO/FELDSPATO & $12042^{\prime} 34,8^{\prime \prime}$ & $\mathrm{s}$ & $39 \circ 20^{\prime} 44,9^{\prime \prime}$ \\
\hline RE-03 & Castro Alves & QUARTZO/FELDSPATO & $122^{\circ} 42^{\prime} 20,2^{\prime \prime}$ & $\mathrm{s}$ & 39ㅇ 21' 09,2" \\
\hline RE-03 & Castro Alves & QUARTZO/FELDSPATO & $12041^{\prime} 34,8^{\prime \prime}$ & $\mathrm{s}$ & $39021^{\prime} 52,9^{\prime \prime}$ \\
\hline RE-03 & Castro Alves & QUARTZO/FELDSPATO & 12 ㅇ 41' 57,1" & $\mathrm{S}$ & $39021^{\prime} 20,1^{\prime \prime}$ \\
\hline RE-03 & Castro Alves & QUARTZO/FELDSPATO & 12 o 42' $32,1^{\prime \prime}$ & $\mathrm{S}$ & 39o $22^{\prime} 24,7^{\prime \prime}$ \\
\hline RE-03 & Castro Alves & QUARTZO/FELDSPATO & $12049^{\prime} 28,2^{\prime \prime}$ & $\mathrm{s}$ & $39025^{\prime} 56,9^{\prime \prime}$ \\
\hline RE-03 & Castro Alves & QUARTZO/FELDSPATO & 12 ㅇ 49' 41,5" & $\mathrm{S}$ & $39025^{\prime} 42,8^{\prime \prime}$ \\
\hline RE-03 & Castro Alves & QUARTZO/FELDSPATO & 12 연 $27,9 "$ & $\mathrm{~S}$ & $39025^{\prime} 54,3^{\prime \prime}$ \\
\hline RE-03 & Castro Alves & QUARTZO/FELDSPATO & 12049 ' 47,1" & $\mathrm{S}$ & $39 \circ 26^{\prime} 04,3^{\prime \prime}$ \\
\hline RE-03 & Castro Alves & QUARTZO/FELDSPATO & 12 o 50' $12,5^{\prime \prime}$ & $\mathrm{s}$ & $39025^{\prime} 51,9^{\prime \prime}$ \\
\hline RE-03 & Castro Alves & QUARTZO/FELDSPATO & $12 \circ 44^{\prime} 15,3^{\prime \prime}$ & $\mathrm{S}$ & $39028^{\prime} 33,2^{\prime \prime}$ \\
\hline RE-03 & Castro Alves & QUARTZO/FELDSPATO & 12 o 43' 47,9" & $\mathrm{s}$ & 39ㅇ $29^{\prime} 03,7^{\prime \prime}$ \\
\hline RE-03 & Castro Alves & QUARTZO/FELDSPATO & $12 \circ 44^{\prime} 15,0^{\prime \prime}$ & $\mathrm{s}$ & $39028^{\prime} 30,1^{\prime \prime}$ \\
\hline RE-03 & Castro Alves & QUARTZO/FELDSPATO & $12 \circ 47^{\prime} 49,3^{\prime \prime}$ & $\mathrm{S}$ & $39 \circ 26^{\prime} 32,7^{\prime \prime}$ \\
\hline RE-03 & Castro Alves & QUARTZO/FELDSPATO & 12 o 40' $23,6 "$ & $\mathrm{~s}$ & $39 \circ 22^{\prime} 48,2^{\prime \prime}$ \\
\hline RE-03 & Castro Alves & QUARTZO/FELDSPATO & 12 o 40' 17,3" & $\mathrm{S}$ & 39ㅇ 22' 50,5" \\
\hline RE-03 & Castro Alves & QUARTZO/FELDSPATO & 12 o 40' 21,9" & $\mathrm{S}$ & $39022^{\prime} 39,1^{\prime \prime}$ \\
\hline RE-03 & Castro Alves & QUARTZO/FELDSPATO & 12 잉 $56,8 "$ & $\mathrm{~S}$ & 39ㅇ $22^{\prime} 58,1^{\prime \prime}$ \\
\hline RE-03 & Castro Alves & QUARTZO/FELDSPATO & 12 은 $40,00,0^{\prime \prime}$ & $\mathrm{S}$ & 39o $22^{\prime} 56,1^{\prime \prime}$ \\
\hline RE-03 & Castro Alves & QUARTZO/FELDSPATO & 12 o 39 ' 55,4" & $\mathrm{S}$ & $39 \circ 23^{\prime} 03,0^{\prime \prime}$ \\
\hline RE-03 & Castro Alves & QUARTZO/FELDSPATO & $12 \circ 39^{\prime} 43,9^{\prime \prime}$ & $\mathrm{s}$ & $39-23^{\prime} 10,4^{\prime \prime}$ \\
\hline RE-03 & Castro Alves & QUARTZO/FELDSPATO & 12 ㅇ $38^{\prime} 30,1^{\prime \prime}$ & $\mathrm{S}$ & $39 \circ 24^{\prime} 26,6^{\prime \prime}$ \\
\hline RE-03 & Castro Alves & QUARTZO/FELDSPATO & $12 \circ 37^{\prime} 56,9^{\prime \prime}$ & $\mathrm{S}$ & $39 \circ 24^{\prime} 03,6^{\prime \prime}$ \\
\hline RE-03 & Castro Alves & QUARTZO/FELDSPATO & $12 \circ 37^{\prime} 34,5^{\prime \prime}$ & $\mathrm{s}$ & 39ㅇ 24' 06,0" \\
\hline RE-03 & Castro Alves & QUARTZO/FELDSPATO & $12 \circ 44^{\prime} 03,2^{\prime \prime}$ & $\mathrm{S}$ & $39 \circ 28^{\prime} 57,3^{\prime \prime}$ \\
\hline RE-03 & Castro Alves & QUARTZO/FELDSPATO & $12 \circ 44^{\prime} 47,5^{\prime \prime}$ & $\mathrm{S}$ & $39026^{\prime} 56,6^{\prime \prime}$ \\
\hline RE-03 & Castro Alves & QUARTZO/FELDSPATO & $12 \circ 45^{\prime} 13,4^{\prime \prime}$ & $\mathrm{s}$ & $39 \circ 26^{\prime} 24,5^{\prime \prime}$ \\
\hline RE-03 & Castro Alves & QUARTZO/FELDSPATO & $12 \circ 44^{\prime} 36,2^{\prime \prime}$ & $\mathrm{S}$ & $39027^{\prime} 26,8^{\prime \prime}$ \\
\hline RE-03 & Castro Alves & QUARTZO/FELDSPATO & $12 \circ 44^{\prime} 32,4^{\prime \prime}$ & $\mathrm{S}$ & $39027^{\prime} 37,8^{\prime \prime}$ \\
\hline RE-03 & Castro Alves & QUARTZO/FELDSPATO & $12 \circ 44^{\prime} 24,6 "$ & $\mathrm{~S}$ & $39027^{\prime} 45,8^{\prime \prime}$ \\
\hline RE-03 & Castro Alves & QUARTZO/FELDSPATO & $12044^{\prime} 51,1^{\prime \prime}$ & $\mathrm{s}$ & $39027^{\prime} 37,8^{\prime \prime}$ \\
\hline RE-03 & Castro Alves & QUARTZO/FELDSPATO & $12 \circ 44^{\prime} 09,8^{\prime \prime}$ & $\mathrm{S}$ & $39 \circ 28^{\prime} 36,0^{\prime \prime}$ \\
\hline RE-03 & Castro Alves & QUARTZO/FELDSPATO & $12 \circ 44^{\prime} 08,6 "$ & $\mathrm{~S}$ & $39 \circ 28^{\prime} 27,8^{\prime \prime}$ \\
\hline RE-03 & Castro Alves & QUARTZO/FELDSPATO & 12 o 43' 55,7" & $\mathrm{s}$ & 39o $28^{\prime} 31,1^{\prime \prime}$ \\
\hline RE-03 & Castro Alves & QUARTZO/FELDSPATO & 12 o 43' 46,5" & $\mathrm{s}$ & $39028^{\prime} 34,1^{\prime \prime}$ \\
\hline RE-03 & Castro Alves & QUARTZO/FELDSPATO & 12 o 43' 54,2" & $\mathrm{S}$ & $39028^{\prime} 23,8^{\prime \prime}$ \\
\hline RE-03 & Castro Alves & QUARTZO/FELDSPATO & $12 \circ 44^{\prime} 17,5^{\prime \prime}$ & $\mathrm{s}$ & $39028^{\prime} 28,1^{\prime \prime}$ \\
\hline RE-03 & Castro Alves & QUARTZO/FELDSPATO & 12 ㅇ 44' $24,1^{\prime \prime}$ & $\mathrm{S}$ & $39 \circ 28^{\prime} 26,3^{\prime \prime}$ \\
\hline RE-03 & Castro Alves & QUARTZO/FELDSPATO & $12045^{\prime} 34,8^{\prime \prime}$ & $\mathrm{s}$ & $39 \circ 22^{\prime} 27,6^{\prime \prime}$ \\
\hline RE-03 & Castro Alves & QUARTZO/FELDSPATO & $12 \circ 41^{\prime} 23,8^{\prime \prime}$ & $\mathrm{S}$ & $39023^{\prime} 56,5^{\prime \prime}$ \\
\hline RE-03 & Castro Alves & QUARTZO/FELDSPATO & $12 \circ 46^{\prime} 40,8^{\prime \prime}$ & $\mathrm{S}$ & $39024^{\prime} 42,1^{\prime \prime}$ \\
\hline RE-03 & Castro Alves & QUARTZO/FELDSPATO & $12 \circ 46^{\prime} 40,6^{\prime \prime}$ & $\mathrm{S}$ & 39ㅇ $24^{\prime} 51,6^{\prime \prime}$ \\
\hline RE-03 & Castro Alves & QUARTZO/FELDSPATO & 12 o 41' 03,8" & $\mathrm{S}$ & 39ㅇ $25^{\prime} 30,3^{\prime \prime}$ \\
\hline RE-03 & Castro Alves & QUARTZO/FELDSPATO & $12 \circ 50$ ' 44,4" & $\mathrm{S}$ & $39 \circ 25^{\prime} 20,7^{\prime \prime}$ \\
\hline RE-03 & Castro Alves & QUARTZO/FELDSPATO & $12 \circ 45^{\prime} 23,4^{\prime \prime}$ & $\mathrm{S}$ & $39 \circ 20^{\prime} 27,0^{\prime \prime}$ \\
\hline RE-03 & Castro Alves & QUARTZO/FELDSPATO & 12 ㅇ 41' 20,2" & $\mathrm{S}$ & 39o $23^{\prime} 30,5^{\prime \prime}$ \\
\hline RE-03 & Castro Alves & QUARTZO/FELDSPATO & $12 \circ 45^{\prime} 46,3^{\prime \prime}$ & $\mathrm{s}$ & $39 \div 20^{\prime} 23,0^{\prime \prime}$ \\
\hline
\end{tabular}




\begin{tabular}{|c|c|c|c|c|c|}
\hline RE-03 & Castro Alves & QUARTZO/FELDSPATO & $12 \circ 45^{\prime} 06,9^{\prime \prime}$ & $\mathrm{S}$ & $39028^{\prime} 50,6^{\prime \prime}$ \\
\hline RE-03 & Castro Alves & QUARTZO/FELDSPATO & $12 \circ 45^{\prime} 19,3 "$ & $\mathrm{~s}$ & 39ㅇ $28^{\prime} 02,7^{\prime \prime}$ \\
\hline RE-03 & Castro Alves & QUARTZO/FELDSPATO & 12 o 43' 54,1" & $\mathrm{S}$ & 39o $28^{\prime} 48,1^{\prime \prime}$ \\
\hline RE-03 & Castro Alves & QUARTZO/FELDSPATO & $12 \circ 43^{\prime} 55,2^{\prime \prime}$ & $\mathrm{S}$ & $39 \circ 29^{\prime} 03,5^{\prime \prime}$ \\
\hline RE-03 & Conceição do Almeida & QUARTZO/FELDSPATO & $12 \circ 49^{\prime} 10,2^{\prime \prime}$ & $\mathrm{s}$ & $39020^{\prime} 13,5^{\prime \prime}$ \\
\hline RE-03 & Santa Terezinha & QUARTZO/FELDSPATO & $12 \circ 37^{\prime} 49,7^{\prime \prime}$ & $\mathrm{S}$ & $39 \circ 27^{\prime} 32,2^{\prime \prime}$ \\
\hline RE-03 & Santa Terezinha & QUARTZO/FELDSPATO & 12 잉 $56,9^{\prime \prime}$ & $\mathrm{S}$ & $39026^{\prime} 50,2^{\prime \prime}$ \\
\hline RE-03 & Santa Terezinha & QUARTZO/FELDSPATO & 12 o 39' 53,8" & $\mathrm{S}$ & $39027^{\prime} 28,0^{\prime \prime}$ \\
\hline RE-03 & Santa Terezinha & QUARTZO/FELDSPATO & 12 은 $41^{\prime} 10,8^{\prime \prime}$ & $\mathrm{S}$ & $39 \circ 27^{\prime} 50,0^{\prime \prime}$ \\
\hline RE-03 & Santa Terezinha & QUARTZO/FELDSPATO & 12 ㅇ 44' $00,8^{\prime \prime}$ & $\mathrm{S}$ & $39029^{\prime} 23,3^{\prime \prime}$ \\
\hline RE-03 & Santa Terezinha & QUARTZO/FELDSPATO & 12 o 43' $08,6 "$ & $\mathrm{~S}$ & 39o $29^{\prime} 38,1^{\prime \prime}$ \\
\hline RE-03 & Santa Terezinha & QUARTZO/FELDSPATO & $12 \circ 42^{\prime} 07,0 "$ & $\mathrm{~S}$ & $39029^{\prime} 14,4^{\prime \prime}$ \\
\hline RE-03 & Santa Terezinha & QUARTZO/FELDSPATO & 12043 & $\mathrm{~S}$ & $39 \circ 29^{\prime} 17,8^{\prime \prime}$ \\
\hline RE-03 & Santa Terezinha & QUARTZO/FELDSPATO & $12 \circ 43^{\prime} 34,8 "$ & $\mathrm{~s}$ & $39029^{\prime} 12,7^{\prime \prime}$ \\
\hline RE-03 & Santa Terezinha & QUARTZO/FELDSPATO & $12 \circ 40^{\prime} 02,7^{\prime \prime}$ & $\mathrm{S}$ & $39027^{\prime} 06,7^{\prime \prime}$ \\
\hline RE-03 & Santa $T$ & QUARTZO/FELDSPATO & $12 \circ 40^{\prime} 46,3^{\prime \prime}$ & $\mathrm{S}$ & $39026^{\prime} 54,1^{\prime \prime}$ \\
\hline RE-03 & Santa Terezinha & QUARTZO/FELDSPATO & $12 \circ 41^{\prime} 04,6^{\prime \prime}$ & $\mathrm{s}$ & $39 \circ 28^{\prime} 06,6^{\prime \prime}$ \\
\hline RE-03 & Santa Terezinha & QUARTZO/FELDSPATO & $12 \circ 41^{\prime} 23,0^{\prime \prime}$ & $\mathrm{S}$ & 39을 $28^{\prime} 57,2^{\prime \prime}$ \\
\hline RE-03 & Santa Terezinha & QUARTZO/FELDSPATO & $12037^{\prime} 22,1^{\prime \prime}$ & $\mathrm{S}$ & $39027^{\prime} 46,0^{\prime \prime}$ \\
\hline RE-03 & Santa Terezinha & QUARTZO/FELDSPATO & $12 \circ 37^{\prime} 14,1^{\prime \prime}$ & $\mathrm{S}$ & $39027^{\prime} 46,4^{\prime \prime}$ \\
\hline RE-03 & Santa Terezinha & QUARTZO/FELDSPATO & $12 \circ 37^{\prime} 42,8 "$ & $\mathrm{~s}$ & $39 \circ 27^{\prime} 39,7^{\prime \prime}$ \\
\hline RE-03 & Santa Terezinha & QUARTZO/FELDSPATO & 12 o 40' 57,1" & $\mathrm{S}$ & 39 o 30 ' 10,9" \\
\hline RE-03 & Santa Terezinha & QUARTZO/FELDSPATO & $12 \circ 42^{\prime} 20,8^{\prime \prime}$ & $\mathrm{S}$ & $39029^{\prime} 57,8^{\prime \prime}$ \\
\hline RE-03 & Santa Terezinha & QUARTZO/FELDSPATO & $12 \circ 39$ ' 51,6" & $\mathrm{S}$ & $39029^{\prime} 46,6^{\prime \prime}$ \\
\hline RE-03 & Santa Terezinha & QUARTZO/FELDSPATO & $12041^{\prime} 35,0^{\prime \prime}$ & $\mathrm{S}$ & 39028 '22,7" \\
\hline RE-03 & Santa Terezinha & QUARTZO/FELDSPATO & $12 \circ 41^{\prime} 19,5^{\prime \prime}$ & $\mathrm{s}$ & $39028^{\prime} 49,6^{\prime \prime}$ \\
\hline RE-03 & Santa Terezinha & QUARTZO/FELDSPATO & $12 \circ 41^{\prime} 32,0 "$ & $\mathrm{~S}$ & $39028^{\prime} 28,2^{\prime \prime}$ \\
\hline RE-03 & Santa Terezinha & QUARTZO/FELDSPATO & $12 \circ 41^{\prime} 28,3^{\prime \prime}$ & $\mathrm{s}$ & $39028^{\prime} 27,5^{\prime \prime}$ \\
\hline RE-03 & Santa Terezinha & QUARTZO/FELDSPATO & $12^{\circ} 41^{\prime} 25,2^{\prime \prime}$ & $\mathrm{s}$ & $39028^{\prime} 49,5^{\prime \prime}$ \\
\hline RE-03 & Santa Terezinha & QUARTZO/FELDSPATO & $12 \circ 40^{\prime} 45,2^{\prime \prime}$ & $\mathrm{S}$ & $39026^{\prime} 58,2^{\prime \prime}$ \\
\hline RE-03 & Santa Terezinha & QUARTZO/FELDSPATO & $12 \circ 41^{\prime} 00,3^{\prime \prime}$ & $\mathrm{S}$ & $39026^{\prime} 46,6^{\prime \prime}$ \\
\hline RE-03 & Santa Terezinha & QUARTZO/FELDSPATO & $12 \circ 44^{\prime} 18,3 "$ & $\mathrm{~s}$ & $39029^{\prime} 18,3^{\prime \prime}$ \\
\hline RE-03 & Santa Terezinha & QUARTZO/FELDSPATO & $12 \circ 40^{\prime} 53,8^{\prime \prime}$ & $\mathrm{S}$ & 39ㅇ $27^{\prime} 15,4^{\prime \prime}$ \\
\hline RE-03 & Santa Terezinha & QUARTZO/FELDSPATO & 12 o 40' 54,7" & $\mathrm{S}$ & $39027^{\prime} 19,5^{\prime \prime}$ \\
\hline RE-03 & Santa Terezinha & QUARTZO/FELDSPATO & $12 \circ 41^{\prime} 08,2^{\prime \prime}$ & $\mathrm{S}$ & $39 \circ 27^{\prime} 20,5^{\prime \prime}$ \\
\hline RE-03 & Santa Terezinha & QUARTZO/FELDSPATO & 12 o 41' 30,9" & $\mathrm{S}$ & $39 \circ 28^{\prime} 50,7^{\prime \prime}$ \\
\hline RE-03 & Santa Terezinha & QUARTZO/FELDSPATO & $12038^{\prime} 35,1^{\prime \prime}$ & $\mathrm{s}$ & 39o $27^{\prime} 30,9^{\prime \prime}$ \\
\hline RE-03 & Santa Terezinha & QUARTZO/FELDSPATO & 12 o 40' $32,7^{\prime \prime}$ & $\mathrm{S}$ & 39ㅇ $28^{\prime} 35,0^{\prime \prime}$ \\
\hline RE-03 & Santa Terezinha & QUARTZO/FELDSPATO & 12 o 40' 59,0" & $\mathrm{S}$ & 39028 ' $28,7^{\prime \prime}$ \\
\hline RE-03 & Santa Terezinha & QUARTZO/FELDSPATO & $12 \circ 41^{\prime} 04,0 "$ & $\mathrm{~s}$ & $39028^{\prime} 34,6^{\prime \prime}$ \\
\hline RE-03 & Santa Terezinha & QUARTZO/FELDSPATO & $12 \circ 41^{\prime} 03,2^{\prime \prime}$ & $\mathrm{S}$ & $39 \circ 28^{\prime} 41,0^{\prime \prime}$ \\
\hline RE-03 & Santa Terezinha & QUARTZO/FELDSPATO & $12 \circ 40^{\prime} 49,0^{\prime \prime}$ & $\mathrm{S}$ & $39028^{\prime} 17,0^{\prime \prime}$ \\
\hline RE-03 & Santa Terezinha & QUARTZO/FELDSPATO & $12 \circ 40$ ' 46,7" & $\mathrm{S}$ & $39028^{\prime} 13,9^{\prime \prime}$ \\
\hline RE-03 & Santa Terezinha & QUARTZO/FELDSPATO & $12 \circ 40^{\prime} 44,7^{\prime \prime}$ & $\mathrm{S}$ & $39028^{\prime} 12,4^{\prime \prime}$ \\
\hline RE-03 & Santa Terezinha & QUARTZO/FELDSPATO & $12 \circ 40^{\prime} 43,0^{\prime \prime}$ & $\mathrm{S}$ & $39028^{\prime} 00,8^{\prime \prime}$ \\
\hline RE-03 & Santa Terezinha & QUARTZO/FELDSPATO & $12 \circ 42^{\prime} 14,2^{\prime \prime}$ & $\mathrm{s}$ & 39ㅇ $28^{\prime} 51,8^{\prime \prime}$ \\
\hline RE-03 & Santa Terezinha & QUARTZO/FELDSPATO & $12 \circ 40^{\prime} 35,0^{\prime \prime}$ & $\mathrm{S}$ & 39ㅇ $28^{\prime} 05,4^{\prime \prime}$ \\
\hline RE-03 & Santa Terezinha & QUARTZO/FELDSPATO & $12^{\circ} 40^{\prime} 47,8^{\prime \prime}$ & $\mathrm{s}$ & $39 \circ 28^{\prime} 07,2^{\prime \prime}$ \\
\hline RE-03 & Santa Terezinha & QUARTZO/FELDSPATO & $12 \circ 40^{\prime} 31,0^{\prime \prime}$ & $\mathrm{S}$ & $39028^{\prime} 05,9^{\prime \prime}$ \\
\hline RE-03 & Santa Terezinha & QUARTZO/FELDSPATO & $12040^{\prime} 13,2^{\prime \prime}$ & $\mathrm{s}$ & 39ㅇ $29^{\prime} 03,4^{\prime \prime}$ \\
\hline
\end{tabular}




\begin{tabular}{|c|c|c|c|c|c|}
\hline RE-03 & Santa Terezinha & QUARTZO/FELDSPATO & $12^{\circ} 42^{\prime} 42,5^{\prime \prime}$ & $\mathrm{s}$ & $39 \circ 30^{\prime} 01,2^{\prime \prime}$ \\
\hline RE-03 & Santa Terezinha & QUARTZO/FELDSPATO & $12 \circ 40^{\prime} 19,1^{\prime \prime}$ & $\mathrm{s}$ & 39o $29^{\prime} 15,6^{\prime \prime}$ \\
\hline RE-03 & Santa Terezinha & QUARTZO/FELDSPATO & $12 \circ 40^{\prime} 24,2^{\prime \prime}$ & $\mathrm{S}$ & 39o $29^{\prime} 20,2^{\prime \prime}$ \\
\hline RE-03 & Santa Terezinha & QUARTZO/FELDSPATO & $12^{\circ} 40^{\prime} 27,5^{\prime \prime}$ & $\mathrm{s}$ & $39029^{\prime} 19,1^{\prime \prime}$ \\
\hline RE-03 & Santa Terezinha & QUARTZO/FELDSPATO & $12^{\circ} 41^{\prime} 36,7^{\prime \prime}$ & $\mathrm{s}$ & $39 \circ 28^{\prime} 03,9^{\prime \prime}$ \\
\hline RE-03 & Santa Terezinha & QUARTZO/FELDSPATO & $12^{\circ} 41^{\prime} 46,2^{\prime \prime}$ & $\mathrm{s}$ & $39 \circ 28^{\prime} 07,4^{\prime \prime}$ \\
\hline RE-03 & Santa Terezinha & QUARTZO/FELDSPATO & $12 \circ 42^{\prime} 37,4^{\prime \prime}$ & $\mathrm{s}$ & 39o $29^{\prime} 43,0^{\prime \prime}$ \\
\hline RE-03 & Santa Terezinha & QUARTZO/FELDSPATO & $12^{\circ} 41^{\prime} 57,6^{\prime \prime}$ & $\mathrm{s}$ & 39ㅇ 29' 51,0" \\
\hline RE-03 & Santa Terezinha & QUARTZO/FELDSPATO & $12^{\circ} 43^{\prime} 07,7^{\prime \prime}$ & $\mathrm{s}$ & $39 \circ 29^{\prime} 28,0^{\prime \prime}$ \\
\hline RE-03 & Santa Terezinha & QUARTZO/FELDSPATO & $12^{\circ} 42^{\prime} 46,1^{\prime \prime}$ & $\mathrm{s}$ & $39 \circ 30^{\prime} 06,8^{\prime \prime}$ \\
\hline RE-03 & Santa Terezinha & QUARTZO/FELDSPATO & $12 \circ 42^{\prime} 51,0^{\prime \prime}$ & $\mathrm{s}$ & $39030^{\prime} 02,5^{\prime \prime}$ \\
\hline RE-03 & Santa Terezinha & QUARTZO/FELDSPATO & $12^{\circ} 41^{\prime} 06,6^{\prime \prime}$ & $\mathrm{s}$ & $39027^{\prime} 15,7^{\prime \prime}$ \\
\hline RE-03 & Santa Terezinha & QUARTZO/FELDSPATO & $12^{\circ} 42^{\prime} 38,8^{\prime \prime}$ & $\mathrm{s}$ & 39을 $29^{\prime} 58,0^{\prime \prime}$ \\
\hline RE-03 & Santa Terezinha & QUARTZO/FELDSPATO & $12^{\circ} 42^{\prime} 06,6^{\prime \prime}$ & $\mathrm{s}$ & $39028^{\prime} 24,2^{\prime \prime}$ \\
\hline RE-03 & Santa Terezinha & QUARTZO/FELDSPATO & $12^{\circ} 38^{\prime} 56,8^{\prime \prime}$ & $\mathrm{s}$ & $39026^{\prime} 14,2^{\prime \prime}$ \\
\hline RE-03 & Santa Terezinha & QUARTZO/FELDSPATO & $12 \circ 43^{\prime} 13,7^{\prime \prime}$ & $\mathrm{s}$ & $39 \circ 29^{\prime} 47,5^{\prime \prime}$ \\
\hline RE-03 & Santa Terezinha & QUARTZO/FELDSPATO & $12^{\circ} 42^{\prime} 35,1^{\prime \prime}$ & $\mathrm{s}$ & $39029^{\prime} 17,4^{\prime \prime}$ \\
\hline RE-03 & Santa Terezinha & QUARTZO/FELDSPATO & $12^{\circ} 42^{\prime} 05,9^{\prime \prime}$ & $\mathrm{s}$ & 39o $29^{\prime} 04,3^{\prime \prime}$ \\
\hline RE-03 & Santa Terezinha & QUARTZO/FELDSPATO & $12 \circ 42^{\prime} 20,8^{\prime \prime}$ & $\mathrm{s}$ & 39을 $28^{\prime} 58,0^{\prime \prime}$ \\
\hline RE-03 & Santa Terezinha & QUARTZO/FELDSPATO & $12 \circ 42^{\prime} 39,3^{\prime \prime}$ & $\mathrm{s}$ & 39-29' 20,1" \\
\hline RE-03 & Santa Terezinha & QUARTZO/FELDSPATO & $12 \circ 42^{\prime} 33,1^{\prime \prime}$ & $\mathrm{s}$ & 39o $29^{\prime} 28,8^{\prime \prime}$ \\
\hline RE-03 & Santa Terezinha & QUARTZO/FELDSPATO & $12 \circ 39^{\prime} 46,9^{\prime \prime}$ & $\mathrm{s}$ & $39027^{\prime} 16,5^{\prime \prime}$ \\
\hline RE-03 & Santa Terezinha & QUARTZO/FELDSPATO & $12^{\circ} 39^{\prime} 51,9^{\prime \prime}$ & $\mathrm{s}$ & $39 \circ 27^{\prime} 09,2^{\prime \prime}$ \\
\hline RE-03 & Santa Terezinha & QUARTZO/FELDSPATO & $12^{\circ} 39^{\prime} 31,6^{\prime \prime}$ & $\mathrm{S}$ & $39 \circ 27^{\prime} 07,3^{\prime \prime}$ \\
\hline RE-03 & Santa Terezinha & QUARTZO/FELDSPATO & $12 \circ 40$ '03,9" & $\mathrm{s}$ & $39 \circ 27^{\prime} 35,7^{\prime \prime}$ \\
\hline RE-03 & Santa Terezinha & QUARTZO/FELDSPATO & $12 \circ 39^{\prime} 47,3^{\prime \prime}$ & $\mathrm{S}$ & $39027^{\prime} 32,2^{\prime \prime}$ \\
\hline RE-03 & Santa Terezinha & QUARTZO/FELDSPATO & $12 \circ 41^{\prime} 49,1^{\prime \prime}$ & $\mathrm{s}$ & $39 \circ 30$ '03,1' \\
\hline RE-03 & Santa Terezinha & QUARTZO/FELDSPATO & $12 \circ 41^{\prime} 55,4^{\prime \prime}$ & $\mathrm{s}$ & 39o $30^{\prime} 04,7^{\prime \prime}$ \\
\hline RE-03 & Santa Terezinha & QUARTZO/FELDSPATO & $12 \circ 40^{\prime} 13,1^{\prime \prime}$ & $\mathrm{s}$ & 39o 29 ' 19,1" \\
\hline RE-03 & Santa Terezinha & QUARTZO/FELDSPATO & $12 \circ 40$ ' $57,9^{\prime \prime}$ & $\mathrm{s}$ & 39ㅇ 29' 09,4" \\
\hline RE-03 & Santa Terezinha & QUARTZO/FELDSPATO & $12 \circ 40^{\prime} 57,6 "$ & $\mathrm{~s}$ & 39o $29^{\prime} 18,1^{\prime \prime}$ \\
\hline RE-03 & Santa Terezinha & QUARTZO/FELDSPATO & $12 \circ 43^{\prime} 30,6^{\prime \prime}$ & $\mathrm{S}$ & 39o $29^{\prime} 25,9^{\prime \prime}$ \\
\hline $\mathrm{RE}-03$ & Santa Terezinha & QUARTZO/FELDSPATO & $12 \circ 43^{\prime} 33,0^{\prime \prime}$ & $\mathrm{s}$ & 39o 29' 17,1' \\
\hline RE-03 & Santa Terezinha & QUARTZO/FELDSPATO & $12 \circ 43^{\prime} 39,7^{\prime \prime}$ & $\mathrm{s}$ & 39o $29^{\prime} 12,4^{\prime \prime}$ \\
\hline RE-03 & Santa Terezinha & QUARTZO/FELDSPATO & $12 \circ 43^{\prime} 38,4^{\prime \prime}$ & $\mathrm{S}$ & $39029^{\prime} 09,3^{\prime \prime}$ \\
\hline RE-03 & Santa Terezinha & QUARTZO/FELDSPATO & $12 \circ 41^{\prime} 13,4^{\prime \prime}$ & $\mathrm{s}$ & $39027^{\prime} 14,9^{\prime \prime}$ \\
\hline RE-03 & Santa Terezinha & QUARTZO/FELDSPATO & $12 \circ 41^{\prime} 39,4^{\prime \prime}$ & $\mathrm{S}$ & $39028^{\prime} 44,5^{\prime \prime}$ \\
\hline RE-03 & Santa Terezinha & QUARTZO/FELDSPATO & $12 \circ 41^{\prime} 43,0^{\prime \prime}$ & $\mathrm{s}$ & $39028^{\prime} 55,8^{\prime \prime}$ \\
\hline RE-03 & Santa Terezinha & QUARTZO/FELDSPATO & $12 \circ 42^{\prime} 46,5^{\prime \prime}$ & $\mathrm{s}$ & $39029^{\prime} 48,9^{\prime \prime}$ \\
\hline RE-03 & Santa Terezinha & QUARTZO/FELDSPATO & $12^{\circ} 42^{\prime} 47,7^{\prime \prime}$ & $\mathrm{s}$ & $39 \circ 29^{\prime} 45,3^{\prime \prime}$ \\
\hline
\end{tabular}

